UNIVERSIDADE DE SÃO PAULO

FACULDADE DE ECONOMIA, ADMINISTRAÇÃO E CONTABILIDADE DEPARTAMENTO DE ADMINISTRAÇÃO PROGRAMA DE PÓS-GRADUAÇÃO EM ADMINISTRAÇÃO

UMA ANÁLISE SOBRE A RELAÇÃO RISCO VERSUS DESEMPENHO EM GOVERNANÇA DE TI: ESTUDOS DE CASO EM ORGANIZAÇÕES PRESTADORAS DE SERVIÇOS DE TI CERTIFICADAS ISO 20.000

Carlos Rodrigo Cordeiro Alves

Orientador: Prof. Dr. Antonio Geraldo da Rocha Vidal

Versão Corrigida

SÃO PAULO 
Prof. Dr. Marco Antonio Zago Reitor da Universidade de São Paulo

Profa. Dr. Adalberto Américo Fischmann

Diretor da Faculdade de Economia, Administração e Contabilidade

Prof. Dr. Roberto Sbragia

Chefe do Departamento de Administração

Prof. Dr. Lindolfo Galvão Albuquerque Coordenador do Programa de Pós-Graduação em Administração 
Alves, Carlos Rodrigo Cordeiro

Uma análise sobre a relação risco versus desempenho em governança de TI: estudos de caso em organizações prestadoras de serviços de TI certificadas ISO 20000 / Carlos Rodrigo Cordeiro Alves. - São Paulo, 2015.

$258 p$

Tese (Doutorado) - Universidade de São Paulo, 2015.

Orientador: Antonio Geraldo da Rocha Vidal.

1. Administração da qualidade 2. Tecnologia da informação 3. Governança de tecnologia da informação 4. Risco 5. Desempenho I. Universidade de São Paulo. Faculdade de Economia, Administração e Contabilidade. II. Título. 


\title{
UMA ANÁLISE SOBRE A RELAÇÃO RISCO VERSUS DESEMPENHO EM GOVERNANÇA DE TI: ESTUDOS DE CASO EM ORGANIZAÇÕES PRESTADORAS DE SERVIÇOS DE TI CERTIFICADAS ISO 20.000
}

\author{
Tese apresentada ao Departamento de \\ Administração da Faculdade de Economia, \\ Administração e Contabilidade da \\ Universidade de São Paulo como requisito \\ para a obtenção do título de Doutor em \\ Ciências.
}

Orientador: Prof. Dr. Antonio Geraldo da Rocha Vidal

$$
\text { Versão Corrigida }
$$

(versão original disponível na Faculdade de Economia, Administração e Contabilidade) 
2015 
A meus pais, por me ensinarem a sempre buscar mais.

A Daniela e Henrique: tudo. Dedico. 
Agradeço a Ana Carolina Riekstin, pelo enorme espírito de colaboração e trabalho em equipe em artigos e capítulo de livro.

Persio Silvestre, pelo asilo em Natal no momento de reflexão para a qualificação.

Ao Prof. Dr. Ronaldo Zwicker (in memoriam), por ter acreditado no potencial do trabalho antes mesmo do seu início.

Aos Profs. Dr. Cesar A. de Souza e Hiroo Takaoka pela orientação durante a banca de qualificação, ajustando os rumos desta pesquisa.

Ao Prof. Dr. Antonio G. R. Vidal por acreditar na continuação do trabalho e orientações nos momentos mais precisos.

Aos profissionais que participaram da pesquisa, com sua valorosa contribuição e disposição para conhecer, trocar experiências e melhorar sempre.

À equipe da PromonLogicalis, pelo apoio nas horas de ausência e por fazerem uma empresa que acredita na formação contínua das pessoas.

A "Os Coxinhas" que me ajudaram a viajar através da música e do meu contrabaixo para relaxar...e ter ainda mais ideias. 
"Um grande número de leis normalmente fornece desculpas ao vício, então um Estado é muito melhor ordenado quando, tendo algumas poucas leis, elas são muito bem cumpridas."

René Descartes "Nada é permanente, exceto a mudança" Heráclito "Podes dizer-me, por favor, que caminho devo seguir para sair daqui? Isso depende muito de para onde queres ir - respondeu 0 gato. Preocupa-me pouco aonde ir - disse Alice."

Nesse caso, pouco importa o caminho que sigas - replicou o gato. 


\section{RESUMO}

A sustentabilidade de uma organização é uma das principais preocupações de um administrador. Portanto, é preciso analisar o equilíbrio dinâmico entre risco e desempenho. Esta relação deve ser estendida à tecnologia da informação, considerando que sua influência sobre o negócio é crescente. Práticas de governança de TI têm sido adotadas como instrumento para padronizar processos e minimizar riscos.

Esta pesquisa teve como foco organizações brasileiras prestadoras de serviços de TI certificadas ISO 20.000. Os principais objetivos foram: elencar os processos críticos da norma para as empresas; o grau de formalismo com o qual são aplicados e identificar fatores de risco e desempenho. O método utilizado foi revisar o uso de conceitos e desenvolver um modelo conceitual sobre eles. A coleta de dados foi realizada em duas fases: questionário on-line e entrevistas com gestores de oito organizações.

As conclusões do estudo mostraram que a norma ISO 20.000 não é aplicada nas organizações tal qual prescrito, não só por suas idiossincrasias, mas também por necessidades de ajustes nos processos da norma. Os fatores encontrados que contribuem negativamente para isto foram: orientação ao atendimento das necessidades dos clientes e formato da decisão sobre investimentos de TI, enquanto os positivos foram: associar riscos a erros das pessoas; cultura de melhoria contínua e controle sobre mudanças. 


\begin{abstract}
Organizational business sustainability is one of the biggest concerns of an administrator, therefore it is needed to analyze the dynamic balance between risk and performance. This relationship must be extended to information technology, considering its growing influence over business. IT governance practices are being adopted as an instrument to standardize processes and minimize risks.
\end{abstract}

This research had its focus on Brazilian IT service provider organizations that are ISO 20,000 certified. Its main objectives were: rank the norm critical processes to companies; formalism degree to which they are applied, and to identify risk and performance factors. The method used was to review concepts usage and developed a conceptual model about them. Data gathering was made in two phases: online questionnaire and interviews with senior managers of eight organizations.

Study conclusions showed that the ISO 20,000 standard is not applied by the organizations as it is prescribed, not only because their idiosyncrasies, but also by their adjustments needs on the norm's processes. Identified factors that negatively contribute to this were: orientation to customer needs fulfillment and IT investments decision format, while positive factors were: associate risks to people's errors, continual improvement culture, and control of changes. 


\section{SUMÁRIO}

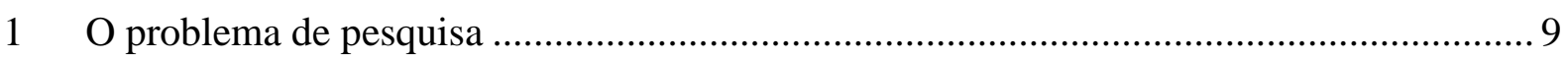

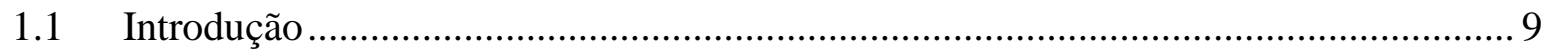

1.2 Formulação do problema de pesquisa …........................................................... 15

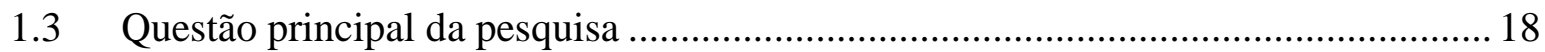

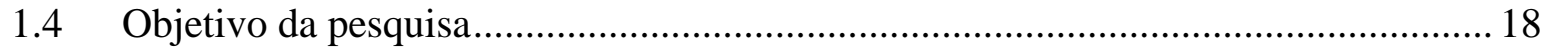

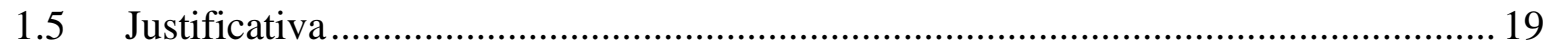

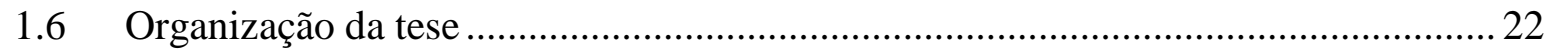

2 Equacionamento da relação risco versus desempenho...................................................25

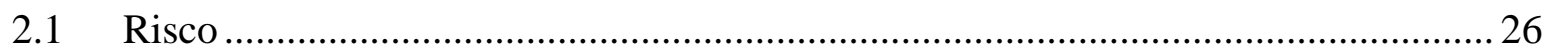

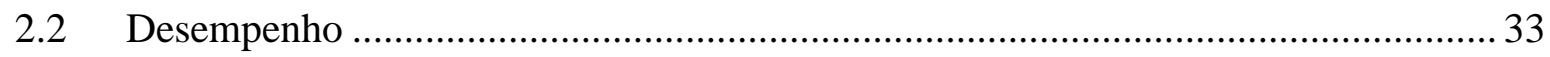

2.3 A relação risco versus desempenho em governança de TI..................................... 40

2.4 O indivíduo e a relação risco versus desempenho .................................................. 41

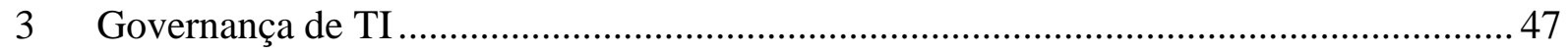

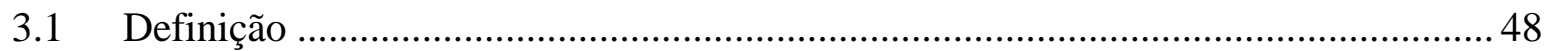

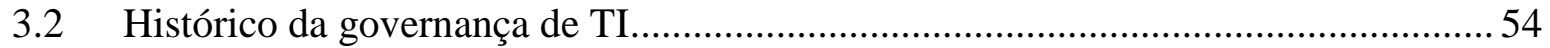

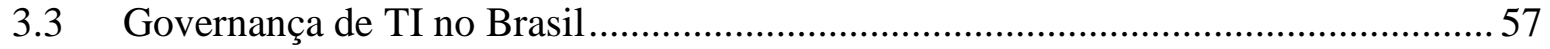

3.4 Modelos padronizados de governança de TI .......................................................... 59

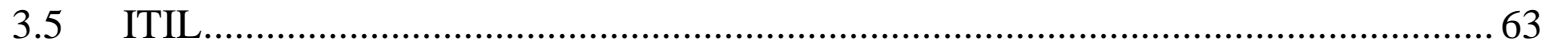

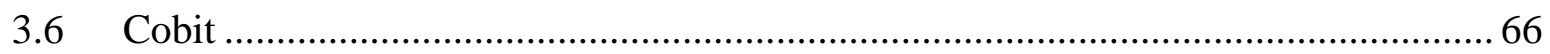

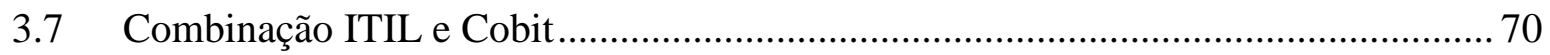

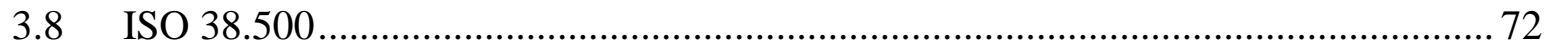

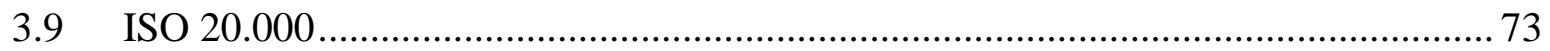

3.10 Modelo canônico de processos de gerenciamento de serviços de TI..................... 74

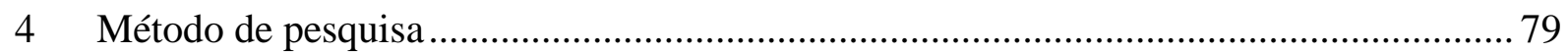

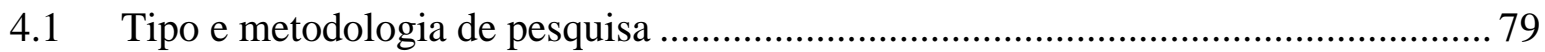




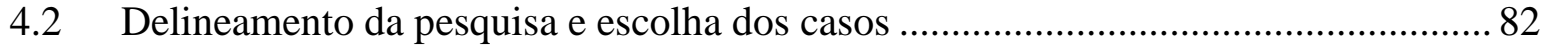

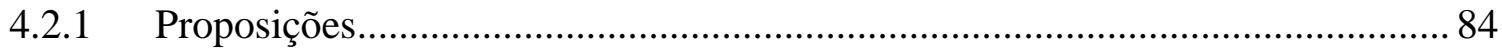

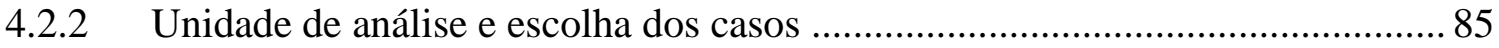

4.2.3 Lógica ligando os dados obtidos às proposições................................................. 89

4.3 Critérios para interpretar as descobertas da pesquisa ........................................... 98

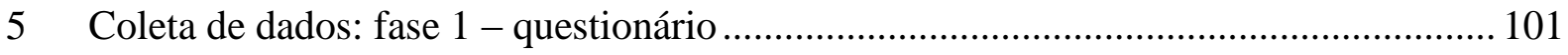

5.1 Qualificadoras, priorização de processos e motivadores ....................................... 101

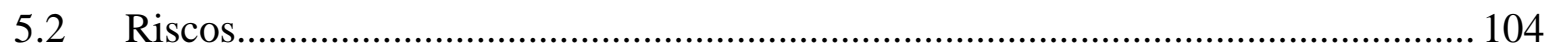

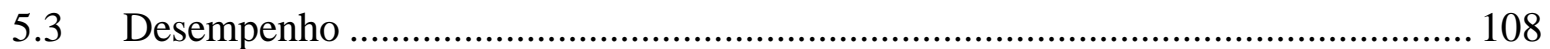

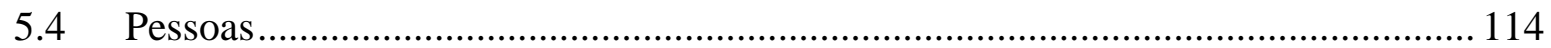

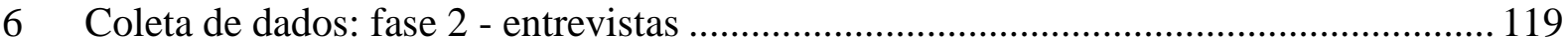

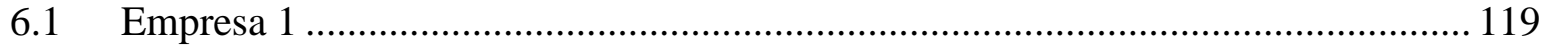

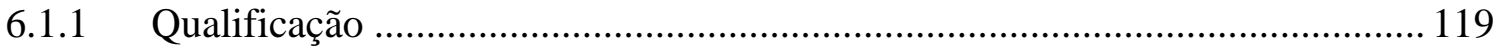

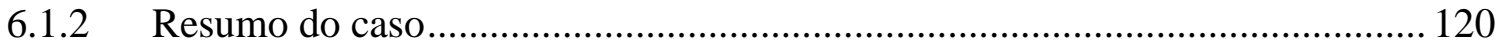

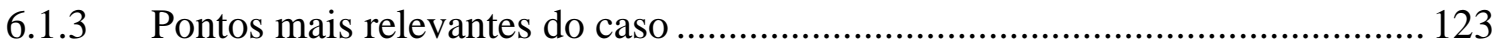

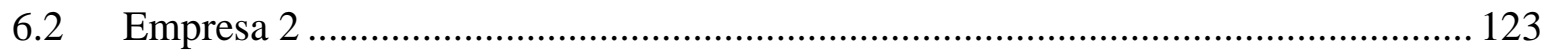

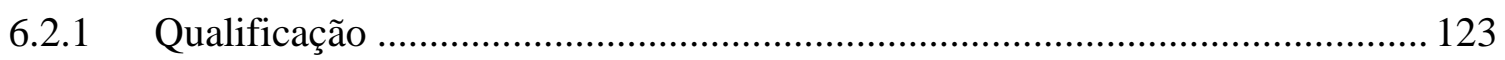

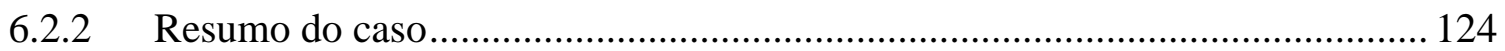

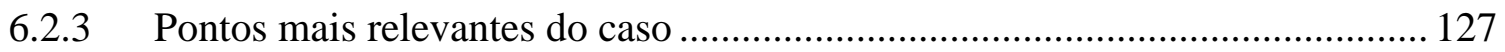

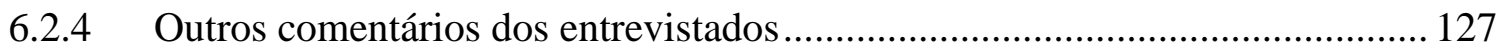

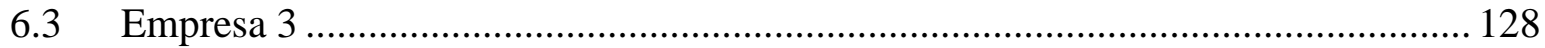

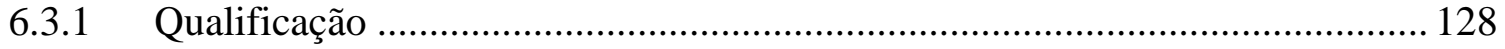

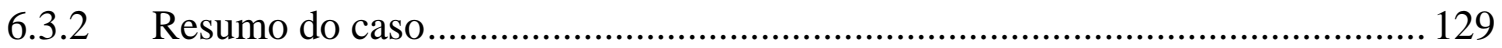

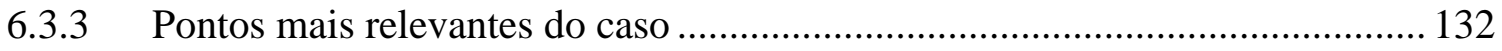

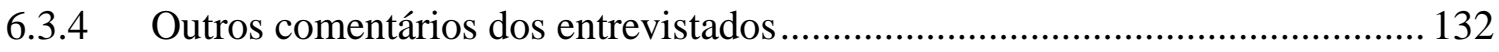

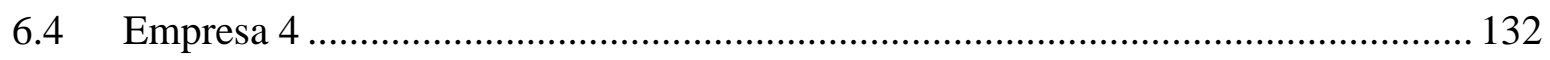

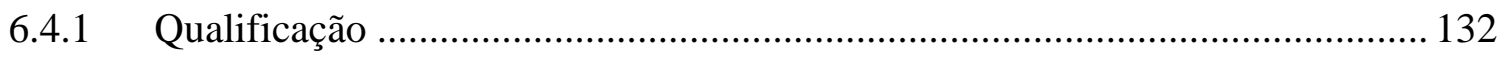




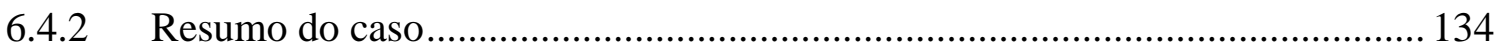

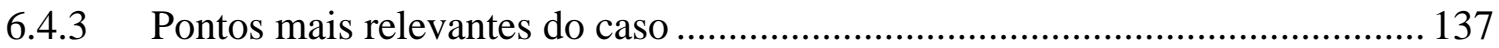

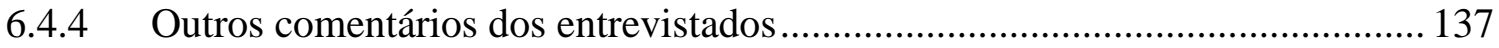

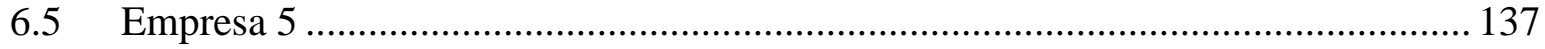

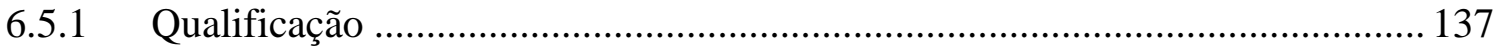

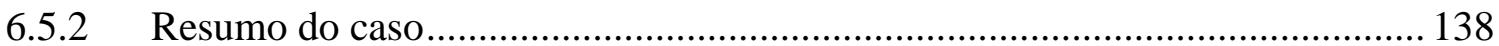

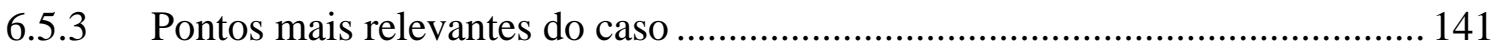

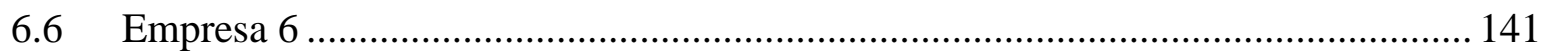

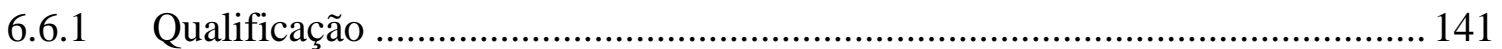

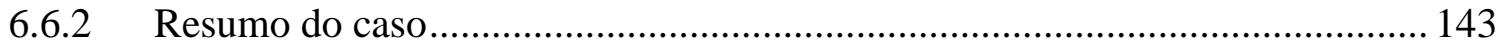

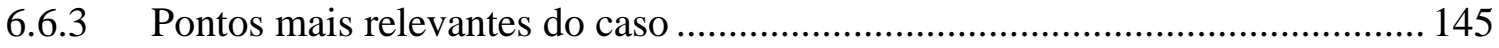

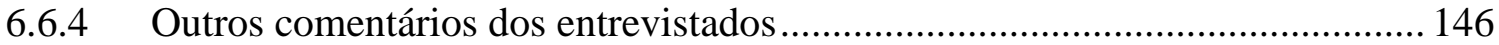

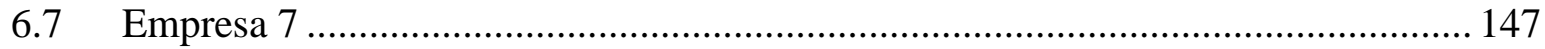

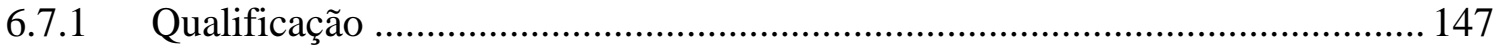

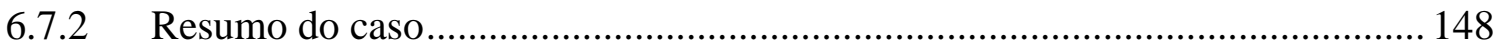

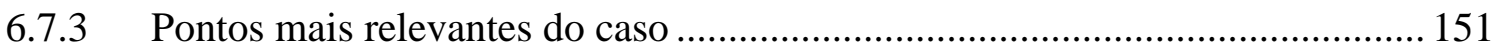

6.7.4 Outros comentários do entrevistado ............................................................ 151

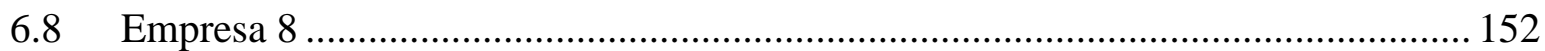

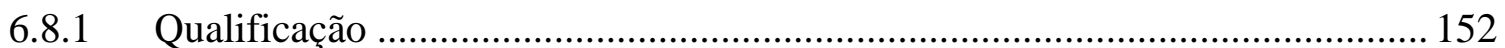

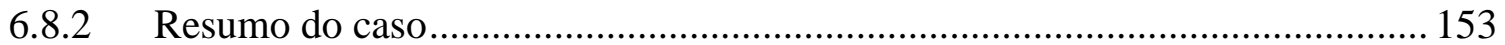

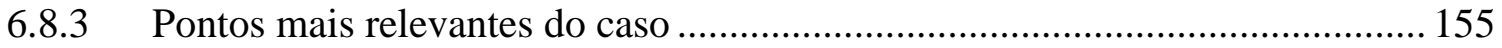

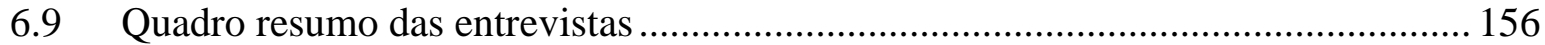

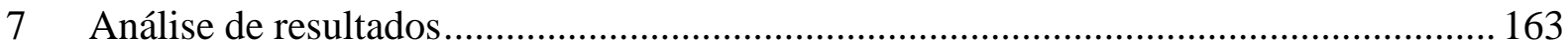

7.1 Conceito de governança de TI e qualificação......................................................... 164

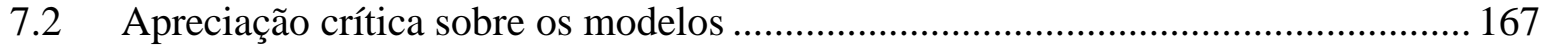

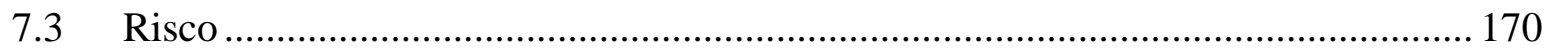

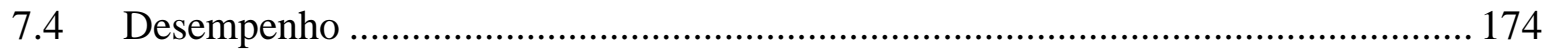




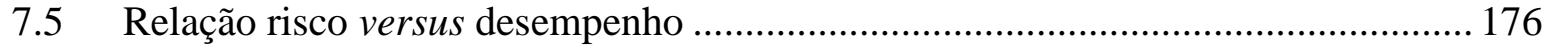

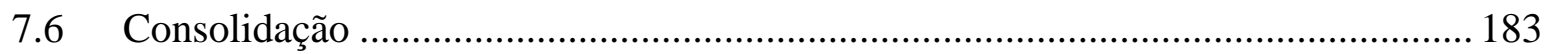

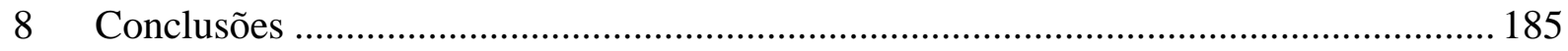

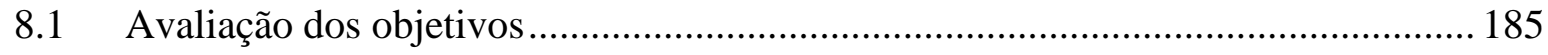

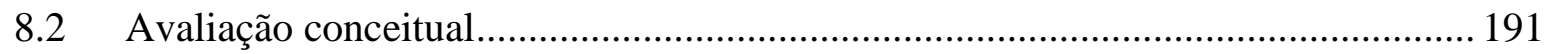

8.3 Avaliação do método de pesquisa ................................................................... 193

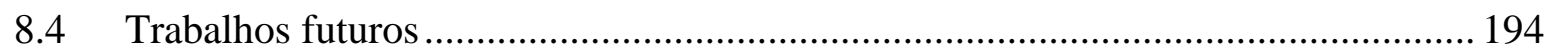

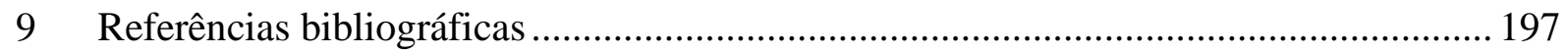




\section{LISTA DE FIGURAS}

Figura 1 - Benefícios de TI na opinião de gestores brasileiros.

Figura 2 - Levantamento bibliométrico sobre governança de TI em organizações brasileiras, apontando a predominância de estudos de caso. .................................................................... 20

Figura 3 - Modelo proposto para detalhamento de vontade e conformidade.

.44

Figura 4 - Modelo adaptado para estudo do comportamento dos profissionais com relação aos processos organizacionais.

Figura 5 - Relacionamento entre modelos de referência e seu foco em processos na organização.

Figura 6 - Modelos de referência de governança de TI adotados por organizações brasileiras.

Figura 7 - Modelo de criação de valor a partir da governança de TI

Figura 8 - Processo iterativo que desdobra a estratégia organizacional nas atividades operacionais de TI. .68

Figura 9 - Comparação entre Cobit 4 e ITIL v2 feita por ISACA. ........................................... 71

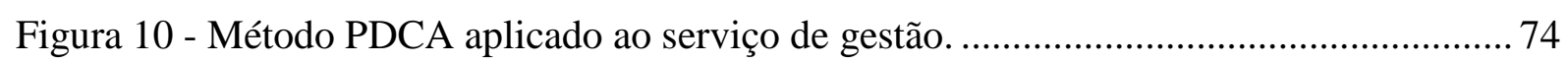

Figura 11 - Método de referência para a pesquisa. ............................................................. 80

Figura 12 - Tamanho das organizações estudadas, em número de profissionais (Q4). ......... 102

Figura 13 - Modelos de melhores práticas adotados pelas organizações estudadas (Q7)..... 103

Figura 14 - Modelos de melhores práticas adotados pelas organizações estudadas (Q8)..... 104

Figura 15 - Atitude típica da organização perante os riscos (Q17). 105

Figura 16 - Atitude típica da organização diante de uma oportunidade inovadora com um cliente (Q18).

Figura 17 - Fatores externos à organização que têm impacto sobre o investimento de TI (Q15). 106

Figura 18 - Fatores internos à organização que têm impacto sobre o investimento de TI (Q16).

Figura 19 - Classificação de riscos internos à organização (Q19). ...................................... 107

Figura 20 - Classificação de riscos operacionais (Q20)................................................... 108

Figura 21 - Processos da norma ISO 20.000 considerados como tendo maior impacto nas operações de TI (Q9). 109 
Figura 22 - Fatores mais importantes para o sucesso da adoção e da manutenção do uso da norma ISO $20.000(\mathrm{Q} 11)$.....

Figura 23 - Motivos mais importantes pelos quais as organizações se certificaram e se mantêm em conformidade com a norma ISO 20.000 (Q10).

Figura 24 - Dificuldades enfrentadas para adotar e manter o sistema de governança de TI em conformidade à norma ISO 20.000 (Q14).

Figura 25 - Benefícios alcançados com a adoção da norma ISO 20.000 (Q12).

Figura 26 - Fatores de desempenho alcançados ao adotar da norma ISO 20.000 (Q13).

Figura 27 - Respostas sobre os registros formais das atividades (Q22).

Figura 28 - Acompanhamento de resultados pelo chefe imediato (Q23).

Figura 29 - Atitudes do chefe imediato em situações de decisão de negócio e no dia-a-dia (Q24 e Q25).

Figura 30 - Relação entre profissionais terem conhecimento sobre os processos de governança de TI e entenderem se refletem a realidade de suas atividades no dia-a-dia (Q26 e Q28). ... 117 Figura 31 - Participação do profissional na definição dos processos de governança de TI (Q27).

Figura 32 - Reflexão em práticas: relação entre os profissionais seguindo os processos documentados e propondo mudanças aos mesmos (Q29 e Q30).

Figura 33 - Processo de decisão sobre investimentos em TI (R1) à esquerda, as regulamentações internas para decisões sobre TI (R11) e como é feito o planejamento para investimentos em TI (D12) abaixo. 164

Figura 34 - Tomada de decisões: como são utilizados os relatórios gerados nos processos para análise de melhoria (R9), conforme índice de maturidade apresentado pelo Cobit (ISACA, 2012)

Figura 35 - Foco do portfólio de serviços de TI (D3) à esquerda, e principal fator de diferenciação da organização (D4), à direita. 166

Figura 36 - Filtro das organizações certificadas ISO 20.000, até dezembro/2013. 169

Figura 37 - Atitude da organização perante o risco (R7). 170

Figura 38 - Fatores internos à organização que têm maior impacto sobre segurança da informação (R5).

Figura 39 - Fatores externos à organização que têm maior impacto sobre segurança da informação (R3), à esquerda, e sobre investimentos em TI (R2), à direita.

Figura 40 - Controle e comunicação das mudanças sobre processos de governança de TI (R10). 
Figura 41 - Entendimento das demandas dos clientes (D7). ........................................... 176

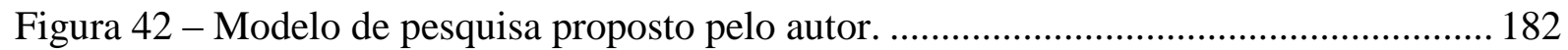

Figura 43 - Consolidação de resultados da relação risco versus desempenho em governança de TI. 184 


\section{LISTA DE TABELAS}

Tabela 1 - Levantamento de publicações sobre governança corporativa, governança de TI e risco.

Tabela 2 - Relacionamento entre riscos operacionais corporativos e de TI.

Tabela 3 - Fatores de risco para tecnologia da informação considerados nesta pesquisa. ...... 31

Tabela 4 - Fatores de desempenho para tecnologia da informação. 38

Tabela 5 - Agrupamento de motivações para adoção de modelos padronizados de governança de TI.

Tabela 6 - Vantagens da adoção de modelo padronizado de governança de TI, segundo Cobit (ISACA, 2012)

Tabela 7 - Princípios propostos pelos modelos de referência de governança de TI. 60

Tabela 8 - Processos de governança de TI segundo ITIL v3.

Tabela 9 - Processos segundo Cobit 5. 68

Tabela 10 - Níveis de maturidade segundo Cobit 5. 69

Tabela 11 - Fatores críticos de sucesso para utilização de modelos padronizados de governança de TI.

Tabela 12 - Condições de qualidade em estudos de caso, aplicadas a esta pesquisa. 83

Tabela 13 - Organizações brasileiras certificadas ISO 20.000 ............................................. 86

Tabela 14 - Fatores de qualificação das organizações pesquisadas......................................... 88

Tabela 15 - Roteiro de entrevistas com questões sobre risco.............................................. 90

Tabela 16 - Roteiro de entrevistas com questões sobre desempenho.

Tabela 17 - Processos da norma ISO 20.000 apontados como principais na pesquisa e seus objetivos relacionados a desempenho e risco.

Tabela 18 - Fatores de sucesso na adoção e da manutenção do uso da norma ISO 20.000 apontados como principais na pesquisa (Q11).

Tabela 19 - Quadro resumo das entrevistas. 156

Tabela 20 - Questões das entrevistas que mostraram o entendimento do conceito de desempenho em relação a requisitos e satisfação dos clientes (D2, D10 e D6). 


\section{O PROBLEMA DE PESQUISA}

\subsection{Introdução}

Uma das importantes preocupações de um administrador de empresas deve ser com relação à sustentabilidade de seu negócio: como manter suas operações e a lucratividade da organização em face de mudanças internas e externas tão constantes nos contextos econômico, político e social.

Esta sustentabilidade depende, dentre outros fatores, da busca incessante pelo equilíbrio entre o desempenho e o risco do negócio. As decisões tomadas na gestão do negócio envolvem diversas variáveis que afetam direta ou indiretamente estas duas grandezas (PINOCHET et al., 2012; CUMPS; VIANE; DEDENE, 2010).

A governança corporativa é um meio pelo qual empresas são dirigidas e controladas, que especifica a distribuição de direitos e responsabilidades entre os diferentes participantes da empresa e que define as regras e procedimentos para se tomarem decisões nos assuntos da empresa (GUERRA; FISCHMANN; MACHADO FILHO, 2009; TIROLE, 2006).

Um fator de regulamentação que ganhou força nos anos 2000 foi a transparência na apresentação dos resultados da organização. Para tratar este tema formalmente, principalmente após a descoberta de gestões fraudulentas em empresas como Parmalat, Enron (CLARKE, 2007) e no Brasil com Encol S/A e Bancos Noroeste-Santander (ANDRADE; ROSSETI, 2006; SILVEIRA; BARROS, 2007), foram estabelecidas práticas de governança corporativa. No Brasil, as regulamentações vêm através do IBGC (Instituto Brasileiro de Governança Corporativa) e Bovespa, com regras para que organizações possam ter ações comercializadas na bolsa de valores nacional (SILVEIRA, 2010) e se verifica um crescente interesse das organizações pela adoção destas práticas (ABIB; HOPPEN; RIGONI, 2012; KITAGAWA, 2007).

Um elemento importante introduzido nesta equação de equilíbrio dinâmico foi a tecnologia da informação (TI). As organizações passaram a depender mais de TI para obtenção, tratamento e 
apresentação de dados referentes ao negócio (LUFTMAN; BEM-ZVI, 2010). De fato a tecnologia da informação pode ser vista como importante habilitadora da governança corporativa, uma vez que contribui com a observação e coleta de dados, armazenamento da informação, processamento e manipulação da informação e sua comunicação, que são elementos para a tomada de decisão (ABRAHAM, 2012). No Brasil, estima-se que o investimento em TI nas grandes e médias empresas esteja em torno de $6 \%$ de seu faturamento líquido anual (MEIRELLES, 2012). Em bancos, estes números superam 10\%.

Com estes investimentos, surgiu um problema a ser enfrentado pelos líderes da organização e seus gestores de TI: as formas de diálogo e apresentação de resultados são incompatíveis, uma vez que a organização estava preocupada com seus resultados e TI com a tecnologia. Para minimizar essas diferenças era preciso compatibilizar as ações de TI com as reais necessidades da empresa (HO; IRELAND; HOSKISSON, 2011).

O equilíbrio dinâmico entre risco e desempenho aplica-se às organizações cujo negócio-fim é a tecnologia da informação. São empresas cujos processos empregados visam lucro através de serviços prestados na área de tecnologia da informação. Tais atividades podem incluir desenvolvimento de software, desenvolvimento de hardware, integração de sistemas e terceirização de serviços de TI (PRADO; CRISTOFOLI; SCHMIDT, 2012; PRADO; TAKAOKA, 2006).

Para o desempenho o gestor de TI procura extrair o máximo dos recursos disponíveis dentro das possibilidades de obter resultados. Um dos instrumentos aplicados para obter eficiência e eficácia é o gerenciamento por processos, com o qual se tenta descrever atividades, seus prérequisitos e seus resultados esperados de modo a auxiliar na comunicação interna e no entendimento do funcionamento desejado da organização (NEIROTTI; PAOLUCCI, 2007).

No Brasil, principalmente na década de 1990, este pensamento levou a um aumento na busca de certificações como ISO 9.001. Exigências em editais públicos e de organizações nas maiores cadeias produtivas, como a automobilística, por exemplo. Porém uma das críticas recorrentes aos sistemas de gestão da qualidade baseado neste conjunto de normas é a de estabelecer controles que permitam a verificação de quanto as atividades podem ser repetidas de maneira consistente, mas não garantem a qualidade final dos produtos ou serviços ou mesmo a satisfação dos clientes (SINGH, 2008; TERZIOVSKI; POWER; SOHAL, 2003). Apesar de baseado no 
ciclo de melhoria contínua de Deming: PDCA - Plan, Do, Check, Act (MAXIMIANO, 2008) executar as atividades segundo processos documentados não é garantia de sustentar o negócio a médio ou longo prazos (CARVALHO; LAURINDO, 2006).

No outro lado da balança há os riscos. A tomada de decisões na organização é permeada pelos contextos externo e interno (HENDERSON; VENKATRAMAN, 1993; MELVILLE, 2004). O primeiro traz aspectos de mercado, competitividade e ordem político-econômica, conforme descrito em três das cinco forças propostas por Porter (MAXIMIANO, 2008). Os clientes foram apontados em pesquisas sobre certificações em normas ISO 9.000 como principal motivador desta necessidade (LIMA; RESENDE; HASENCLEVER, 2000; SINGH, 2008;). Estes passaram a exigir as certificações organizacionais para participação em processos de concorrência. A pressão dos concorrentes vem pela velocidade e percepção no mercado: as empresas mais rápidas a obter as certificações estão mais habilitadas a fornecer a seus clientes. Como continuidade natural da cadeia de produção, a organização passa a exigir de fornecedores as mesmas certificações (CHATZOGLOU; DIAMANTIDIS, 2009; LIMA; RESENDE; HASENCLEVER, 2000), uma vez que pode comprovar sua conformidade aos processos dado o certificado de seus fornecedores.

As organizações passaram a exigir certificações de seus fornecedores para mitigarem riscos com relação a atividades contratadas. A terceirização de serviços de tecnologia da informação se intensificou a partir dos anos 2000, trazendo desafios às organizações de como poderiam decidir melhor pelo prestador de serviços (PRADO; CRISTOFOLI; SCHMIDT, 2012). Do ponto de vista interno à organização, a adoção de referenciais também vem da necessidade de mitigar riscos operacionais relacionados à tecnologia da informação, com a visão de que o aumento do controle sobre as atividades pode influenciar positivamente nos resultados organizacionais.

Particularmente para a adoção do modelo ITIL (Information Technology Infrastructure Library), a motivação veio da exigência do governo do Reino Unido para seus prestadores de serviço e consequente cadeia produtiva (TAYLOR et al., 2007). Com relação ao modelo Cobit (Control Objectives for Information and related Technology), as necessidades de auditoria sobre o processamento de dados relativo ao desempenho dos negócios fizeram com que este modelo fosse procurado pelas organizações (SILVEIRA, 2010). 
Esta movimentação na cadeia produtiva acabou aumentando a procura por consultorias, treinamentos e certificações voltadas a normas e modelos de boas práticas (KESSLER, 1995; LIMA; RESENDE; HASENCLEVER, 2000). Porém, conforme estudos voltados à norma ISO 9.001 (LEE; PALMER, 1999; LO et al., 2013; SINGH, 2008; TERZIOVSKI; POWER; SOHAL, 2003), esta busca por um certificado não necessariamente refletiu em melhora de produtos ou serviços entregues pelas organizações (CORBETT; KIRSCH, 2001; NAVEH; MARCUS, 2005).

Sobre o contexto interno, este é diretamente ligado à sustentabilidade do negócio e às pessoas envolvidas na tomada de decisão em nome da organização. Os processos operacionais de gerenciamento da tecnologia da informação prescrevem atividades e papéis para os profissionais já presentes na empresa, que devem passar por alterações em suas rotinas para estarem em conformidade com o modelo que passa a ser exigido pela organização.

O papel da alta administração é fundamental para o sucesso das implantações de modelos normativos, pois é de onde normalmente surge a demanda pela certificação, e consequente conformidade de práticas (TAYLOR, 1995; TERZIOVSKI; POWER; SOHAL, 2003). Os esforços gerados internamente na organização para sua adequação a modelos de referência são processos de mudança, que naturalmente introduzem conflitos entre o prescrito e a realidade do dia-a-dia da operação (BECK; BECK-GERNSHEIN, 2002; DECOSTER, 2008; FISCHER, 1989; MOHRMAN et al., 1991).

A maneira de lidar com o risco é inerente às pessoas: pode-se assumir um comportamento propenso ou avesso a riscos. O primeiro leva a decisões mais arrojadas e podem ser tomadas sobre um ambiente com grau de incerteza maior. Um paralelo é o mercado de ações comparado à poupança: por ter maior risco, pode levar a ganhos - ou perdas - expressivamente maiores. $\mathrm{O}$ segundo leva a decisões mais conservadoras dentro de parâmetros mais usuais e conhecidos na organização. Hofstede (1991) conduziu um estudo sobre estas atitudes, classificando-as por país. No Brasil, segundo estudo de realizado por Fleury A. e Fleury M.T.L. (2012), notou-se que a maioria dos líderes possui maior inclinação para o conservadorismo e procura arriscar menos.

Para minimizar os riscos, busca-se maior grau de certeza para o momento de tomada de decisão, o que acarreta maior coleta de dados e necessidade por mecanismos de controle. Este é um dos 
importantes objetivos do gerenciamento por processos: tornar explícito conhecimento que esteja com indivíduos e possam ser transmitidos para outras pessoas, de modo a diminuir a dependência sobre determinados profissionais.

Ao se colocar desempenho e risco na balança, vê-se então como uma organização tende a se portar perante o mercado, como acomoda suas pressões internas e toma suas decisões para manter-se competitiva.

A governança de TI traz insumos para definir os modelos de responsabilidade quanto à tomada de decisões dentro da organização com relação à tecnologia adotada (WEILL; ROSS, 2004). Foram publicados modelos, a partir de diferentes associações de autores, sob o título de referências de melhores práticas. Alguns dos principais destes modelos, em termos de adoção por organizações através do mundo, apresentam princípios similares quanto a definições de governança de TI.

ITIL é um destes modelos e está atualmente em sua versão 3 (TAYLOR et al., 2007). O modelo foi muito ampliado em comparação à versão anterior, buscando incorporar disciplinas de marketing e gestão do conhecimento. Sua adoção foi iniciada em organizações prestadoras de serviços para os órgãos de governo do Reino Unido, mas logo foi expandido para organizações cujo negócio-fim era a TI. Porém, dada a sua aceitação, muitas empresas buscaram aplicar o modelo a seus departamentos de TI, precisando adaptá-lo a esta realidade.

As áreas internas de TI ainda hoje têm dificuldade para se compreenderem como prestadoras de serviços aos demais departamentos e ao próprio negócio (GARTNER, 2014; ROMERO, 2012). Esta visão é determinante para a aceitação e aplicabilidade do modelo, uma vez que deverão ser adotados conceitos como portfólio de serviços e acordos de níveis de prestação dos mesmos. Sem esta formalização, a utilização do modelo se torna vazia e sem justificativa.

Cobit encontra-se na versão 5. O modelo evoluiu de um guia de referência para auditorias de conformidade, com forte influência de práticas de segurança da informação, para um modelo de gestão mais amplo. Preocupou-se em apresentar as interações entre os acionistas, corpo diretivo, gerencial e operações. Atualmente se apoia no objetivo de criação de valor da tecnologia da informação para o negócio, traduzidas nas necessidades das partes interessadas 
(stakeholders). Para gerar o valor, é preciso: otimizar riscos, otimizar recursos e alcançar os benefícios planejados.

A norma ISO 20.000 (ASSOCIAÇÃO BRASILEIRA DE NORMAS TÉCNICAS, 2011) foi publicada como padrão internacional em 2005 (Standards Org, 2013), traduzida como norma da ABNT em 2008. Seu principal objetivo foi transformar em requisitos certificáveis as práticas de gerenciamento de serviços de TI. Esta norma é inspirada na norma inglesa BS 15.000, sendo fortemente baseada em ITIL.

O aumento do número de modelos de referência em geral causa problemas pela dificuldade de entendimento e definição de termos, bem como a comparação entre organizações similares para validar a aplicação de melhores práticas.

Por um lado, os clientes exigem que a organização estabeleça controles que não estão presentes em seus próprios processos, uma vez que está contratando os serviços de TI. A governança de TI ajuda a controlar a relação entre risco e desempenho. Porém se os modelos são diferentes e múltiplos, o gestor pode deixar de escolher de uma maneira independente o modelo mais adequado à sua organização, e adotar o que é exigido pelo mercado.

Por exemplo, podemos considerar que ITIL tornou-se amplamente difundido ao apresentar uma biblioteca de conhecimento juntamente com um modelo de certificação e provas para os profissionais: ficava claro o que era exigido para sua adoção. Por outro lado, isto tende a alimentar uma indústria de treinamentos, certificações e consultorias cuja fundamental contribuição com o equilíbrio da relação risco e desempenho numa organização de TI é complexa de se medir objetivamente.

Os modelos de referência de governança de TI apresentam processos para melhorias operacionais, visando sua padronização e diminuição de erros por parte dos profissionais. A relação custo-benefício da implantação e manutenção de práticas deve ser estudada pelo administrador da organização, dependendo de quanto estas podem efetivamente afetar o equilíbrio entre desempenho e risco do negócio. 


\subsection{Formulação do problema de pesquisa}

Para manter-se em operação, uma organização necessita sustentar seus negócios (CARVALHO; LAURINDO, 2006). Desse modo é preciso, entre outras coisas, equilibrar suas ações quanto a riscos e desempenho.

Observando as tendências de prioridades dos gestores de organizações, no que tange à tecnologia da informação, a governança de TI se apresenta como um ponto de destaque nos itens realçados por se voltar à "entrega de valor ao negócio e mitigar riscos” (DUFFY, 2008), estando presente nas principais prioridades dos gestores de TI nas organizações nos últimos anos (GARTNER, 2014):

- $\quad$ Entregar resultados operacionais;

- Melhorar o crescimento organizacional;

- $\quad$ Melhorar processos de negócio;

- $\quad$ Melhorar controles gerenciais.

Porém há entendimentos diferentes sobre o tema. Como primeiro passo, portanto, torna-se relevante a necessidade de compreender o que é um sistema de governança de TI e como este pode contribuir para os objetivos da organização, evitando assim dispersão de investimentos.

No Brasil, como apontado no estudo realizado por Cerioni; Buzo e Shibata (2014) e ilustrado na Figura 1, os gestores apontam produtividade e suporte à tomada de decisão como maiores benefícios trazidos pela tecnologia da informação, que são associados à governança de TI.

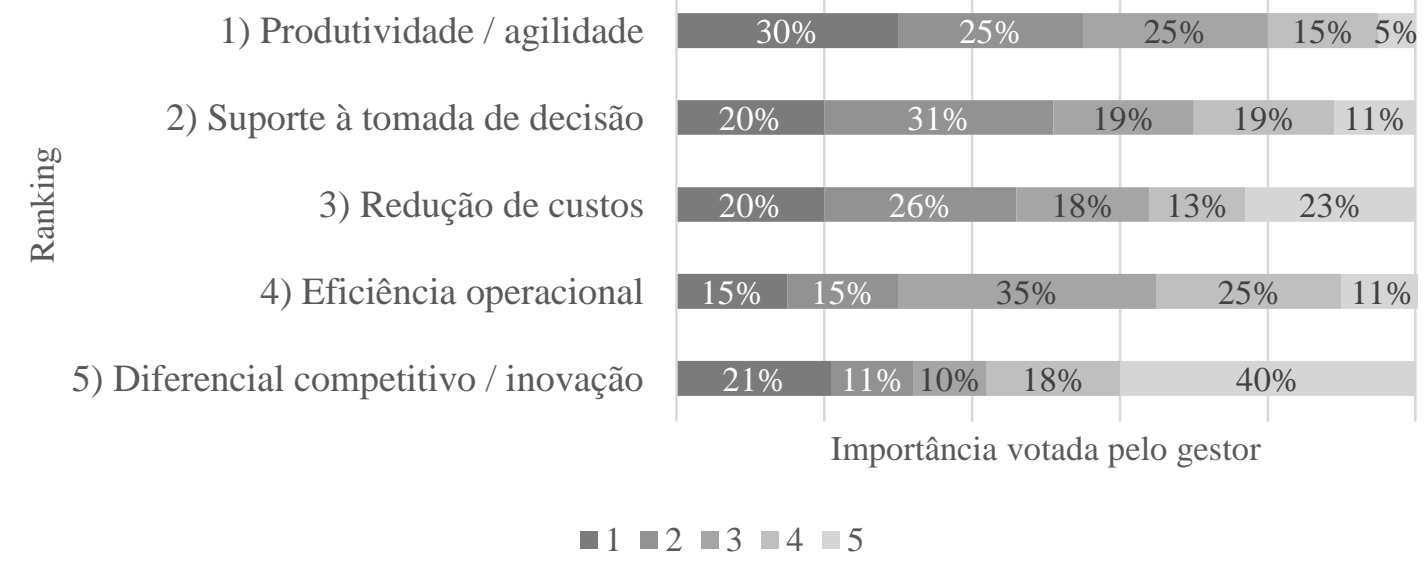

Figura 1 - Benefícios de TI na opinião de gestores brasileiros. FONTE: Cerioni; Buzo e Shibata, 2014. 
Os modelos publicados sobre práticas de governança de TI serão referenciados nesta pesquisa como modelos padronizados de governança de TI, de forma a identificá-los como parte das práticas que são analisadas segundo requisitos estabelecidos formalmente.

Ao se investigar com mais detalhes a causa desta atenção aos modelos de governança de TI, nota-se a relação direta com a necessidade de redução de custos (GARTNER, 2014; WEILL; WOERNER, 2013). Um dos meios utilizados para atingi-la é aumentar o controle sobre as atividades executadas na organização. O gerenciamento por processos estabelece práticas, atividades e responsabilidades que precisam ser seguidas pelos profissionais.

A utilização dos modelos de referência e sua aplicação na organização é um processo de mudança. O processo de mudança é o contexto no qual acontecem os conflitos de poder e cultura dentro do contexto de uma organização. Assim sendo, é válido estabelecer as diferenças entre os conceitos de mudança e transformação organizacional.

A implantação de um sistema de gestão por processos não é apenas o projeto da certificação: é uma transformação contínua da organização, na busca incessante de aplicação de melhoria contínua e desenvolvimento de suas práticas (RHINOW, 2006; SASAKI, 2001). Os modelos de referência disponíveis buscam reunir maneiras de trabalho consolidados pelas organizações que contribuem com sua elaboração (INFORMATION SYSTEM AUDIT AND CONTROL ASSOCIATION, 2012; TAYLOR et al., 2007).

Estudos realizados por Brown e Grant (2005), Weill e Ross (2004), Sambamurthy e Zmud (1999) buscam explicar essas relações através da estrutura da organização e onde estariam localizados de fato, e não simplesmente onde apontados formalmente em um organograma, os tomadores de decisão.

Singh (2008) utiliza pesquisa qualitativa para levantar informações sobre organizações que utilizam o sistema de gestão da qualidade certificado na norma ISO 9.000, buscando informações sobre sucesso da implantação, desempenho e gerenciamento de risco.

As relações de poder são analisadas pelo aspecto das interações entre as pessoas. A exemplo do verificado com a cultura organizacional, estas relações passam diretamente pelos indivíduos. $\mathrm{O}$ 
modo como interagem, seus interesses e ações mostram na prática como as responsabilidades são atribuídas e exercidas na organização. A aplicação de modelos de gestão por processos é prescritiva: com o objetivo de aumentar o controle, introduzem uma pressão sobre os indivíduos (DECOSTER, 2008; DIAS, 2008). A maneira como as responsabilidades e o poder se distribuem determinam como a organização funciona (FISCHER, 1989).

Portanto, sendo a governança um sistema de alocação de responsabilidades e controle, a governança corporativa determina a necessidade por governança de TI, uma vez que as organizações dependem de TI (MEIRELLES, 2012) e devem estar em conformidade com requisitos regulatórios e de negócios (GUERRA; FISCHMANN; MACHADO FILHO, 2009). Em outras palavras, a governança de TI se enquadra neste contexto uma vez que a organização depende de TI para entregar seus resultados ao mercado.

Para as organizações prestadoras de serviços de TI, é importante apresentar credenciamento aos clientes para provarem que são capazes de entregar serviços de qualidade (PRADO; CRISTOFOLI; SCHMIDT, 2012; PRADO; TAKAOKA, 2006). Estas exigências são feitas pelos clientes e passam a direcionar as escolhas de mercado.

Com todo este complexo contexto, os investimentos neste processo de mudança devem ser questionados. Cerioni; Buzo e Shibata (2014) e Kessler e Chakrabarti (1996) levantaram que organizações gastam centenas e, algumas vezes, milhares de dólares ao treinar seus profissionais em processos e qualidade, somente para descobrir que eles não seguem as regras: após o treinamento voltam a fazer as atividades como estavam acostumados.

Este conflito levanta questões como: quão importante é utilizar um modelo de referência de melhor prática? Como estes modelos afetam o equilíbrio entre risco e desempenho? Qual a real necessidade de investimentos em treinamentos e consultorias puramente voltadas aos modelos de referência? Tais investimentos podem diminuir riscos e aumentar o desempenho? Quais fatores podem contribuir positiva ou negativamente na adoção nas práticas de governança de TI? Como melhor ajustar os modelos de referência à realidade da organização, considerando suas necessidades e possibilidades? 


\subsection{Questão principal da pesquisa}

Para conduzir a realização deste estudo, as principais questões de pesquisa proposta foi:

- $\quad$ Os modelos de referência de governança de TI são utilizados conforme originalmente prescritos, em organizações cujo negócio-fim é a prestação de serviços de TI?

- Se não são, quais fatores contribuem para as diferenças em relação ao originalmente prescrito e ao efetivamente aplicado?

- Quais são positivos e quais são negativos para obtenção do melhor equacionamento da relação risco versus desempenho?

Entendendo-se neste contexto risco como o impacto negativo do exercício de uma vulnerabilidade, considerando tanto a probabilidade quanto o impacto de sua ocorrência e desempenho como a forma de medir se uma organização atingiu seus objetivos e se é capaz de se sustentar como negócio.

\subsection{Objetivo da pesquisa}

Este trabalho tem como objetivo principal descrever e analisar os fatores associados à aplicação de modelos padronizados de governança de TI em organizações prestadoras de serviços de TI. Desta forma, pretende colaborar com o aprofundamento do conhecimento sobre a adoção de práticas de governança de TI.

Para tomar-se uma base de organizações com contextos similares, foram pesquisadas organizações brasileiras cujo negócio-fim é a prestação de serviços de tecnologia da informação, sendo certificas ISO 20.000. Define-se modelo canônico como um referencial publicado que pode ser usado para comparação de práticas executadas na organização, segundo conceito apresentado por Brown e Duguid (1991). Neste trabalho adotou-se a norma ISO 20.000 como modelo canônico de governança de TI, uma vez que se torna a referência publicada à qual serão comparadas as práticas executadas nas organizações brasileiras participantes da pesquisa. 
Em relação aos resultados da pesquisa, são buscadas três contribuições. A primeira é o resultado sobre quais são os processos mais críticos para as organizações brasileiras que seguiram todos os passos requeridos e conseguiram se certificar em ISO 20.000.

A segunda é uma contribuição teórica, ao aprofundar o detalhamento do grau de formalismo com que os processos prescritos nos modelos padronizados de governança de TI são aplicados nas organizações. Esta visão traz um complemento aos modelos com dados, por exemplo, sobre características dos profissionais envolvidos. A literatura se mostrou carente neste tipo de classificação (ABIB; HOPPEN; RIGONI, 2012; KO; FINK, 2010; LUCIANO; BECKER; TESTA, 2012; MOHAMED et al., 2012; PIRSON; TURNBALL, 2011;). A categorização das mudanças (TAYLOR et al., 2007) leva em conta os conceitos de impacto e urgência, porém pouco se explora a sua natureza por complexidade: o que é uma mudança simples, que poderia demandar menor controle? Esta dimensão é explorada nos casos estudados.

A terceira contribuição é desenvolver o modelo de fatores que influenciam a utilização dos modelos padronizados de governança de TI, tais como prescritos ou modificados pela realidade das organizações levantados através de estudos de casos múltiplos, para que futuramente sejam realizadas pesquisas quantitativas que possam ser aplicadas de maneira mais ampla em outras organizações. Observando o método desenvolvido por Webster e Watson (2002), é necessário desenvolver um modelo conceitual para validá-lo posteriormente. Fundamentalmente, esses fatores se apresentam na busca do equilíbrio entre risco e desempenho.

\subsection{Justificativa}

Os modelos padronizados de governança de TI proliferaram, mas as organizações optam por utilizar um modelo próprio, para melhor refletir suas idiossincrasias. Gastos corporativos com treinamentos, consultorias e projetos sobre os modelos de governança de TI são expressivos (CERIONI; BUZO; SHIBATA, 2014; KESSLER; CHAKRABARTI, 1996).

Ao encontrar respostas para a questão principal de pesquisa (Seção 1.3) procura-se auxiliar os gestores das organizações na decisão sobre investimentos voltados a modelos de referência de governança de TI. 
Os processos de certificação formais através de organismos certificadores e auditorias externas geram uma série de esforços dentro da organização, para ordenar e formalizar processos e evidências de conformidade. Este processo deve ser proveitoso para a organização não somente no sentido de obter o certificado e reconhecimento em sua cadeia produtiva. Deve ser além desta atividade burocrática, um momento de revisão de práticas e atividades da organização para melhorar sua eficácia e eficiência ao se utilizar modelos de melhor prática como benchmarking. Equilibrar a relação entre os riscos a que os negócios estão expostos pela operação de TI e seu desempenho deve ser parte da decisão da organização sobre investir na adoção de modelos padronizados de governança de TI.

Em termos acadêmicos há poucos trabalhos que aprofundam a utilização do modelo canônico de governança adotado - ISO 20.000 - em organizações brasileiras. De acordo com o estudo bibliométrico realizado anteriormente (ALVES et al., 2013), nota-se a predominância de estudos de caso nas publicações brasileiras sobre governança de TI, conforme apresentado na Figura 2.

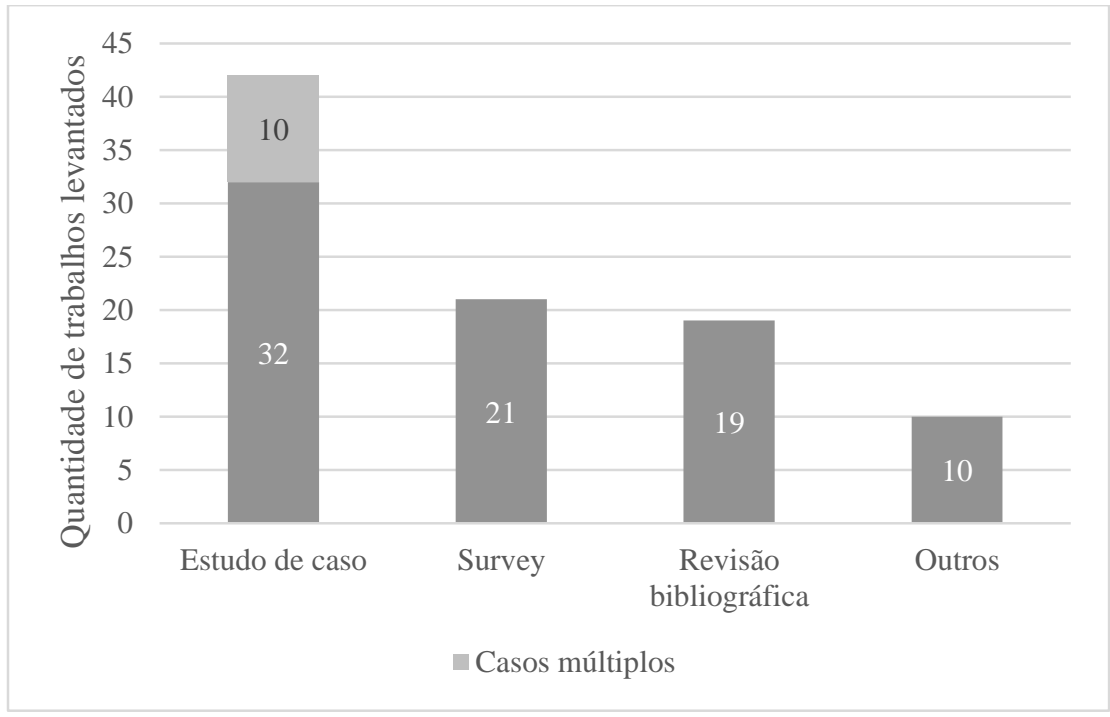

Figura 2 - Levantamento bibliométrico sobre governança de TI em organizações
brasileiras, apontando a predominância de estudos de caso. FONTE: ALVES et al., 2013.

Contudo foi observado no estudo que a maioria dos trabalhos não apresentava análises sobre o gerenciamento de riscos e o desempenho dos serviços de TI: muitas vezes eram apresentados os modelos, deixando de investigar as estruturas de tomada de decisão dentro das organizações 
ou os impactos da sua implantação. Não houve preocupação nos estudos de apresentar como os processos de TI se relacionam com o negócio ou como seu desempenho poderia levar a ganhos competitivos.

Não foram propostas análises críticas sobre a utilização dos modelos padronizados de governança de TI nas organizações estudadas. Por exemplo, o modelo de Weill e Ross (2004) é citado em $25 \%$ destas pesquisas, porém não se utilizou o modelo padronizado para gerar recomendações de melhoria ou apontar diferenças entre o que as organizações praticavam em sua realidade, nem houve crítica ao modelo.

Portanto, houve a motivação de contribuição para a literatura desta área ao propor a exploração de como o modelo canônico de governança de TI é aplicado na realidade de organizações brasileiras, trazendo uma análise crítica sobre suas reais contribuições para gerenciamento de risco e desempenho. Selltiz et al. (1965) afirmam que estudos exploratórios têm ênfase na descoberta de ideias e discernimentos, a partir da familiarização com determinado fenômeno.

Autores como Cumps; Viane e Dedene (2010), Ho et al. (2010), Nfuka e Rusu (2011), Powell e Dent-Micallef (1997) discutem a importância do alinhamento de TI com o negócio devido a sua capacidade de gerar resultados à organização. Powell e Dent-Micallef (1997) defendem a observação da utilização de recursos humanos, de negócio e de tecnologia da informação, sendo que estes últimos são tratados como apoio.

Outros estudos (GARTNER, 2014; KESSLER; CHAKRABARTI, 1996) apontam que os administradores entendem que TI tem a capacidade e a responsabilidade de trazer inovação e valor direto ao negócio. Porém na prática o que se observa é uma constante luta da área ou organização de TI para redução de custos (CERIONI; BUZO; SHIBATA, 2014; DUFFY, 2008; GARTNER, 2013;).

Em contraponto à utilização de modelos padronizados de governança de TI como caminho para melhoria de resultados, autores questionam em seus estudos a importância por vezes exagerada dada a esses controles.

Carr (2003) aponta a tecnologia da informação com o um meio, como outros, de como a organização atinge seus objetivos de negócio. Sua importância para o desempenho dos negócios 
é relativa e tal qual deve ser tratada: sem investimentos desproporcionais em sistemas de gestão e administração. Seu foco deve ser em desempenhar adequadamente as suas funções para com o uso de tecnologia apoiar o negócio.

Ciborra (1997) questiona a real necessidade do alinhamento entre a tecnologia da informação e a estratégia da organização. O distanciamento entre e a "necessidade de voltar aos fatos, colocando em perspectiva conceitos como estratégia, tecnologia e em geral o poder dos modelos e representações". A crítica recai sobre a importância exagerada, e consequentes custos, em projetos de adequação a modelos padronizados de governança de TI.

O autor também desenvolve a ideia de que, mais importante que a prescrição de processos para gerenciamento, é necessário cuidar dos profissionais e da maneira como se organizam para executar as atividades. Através deste cuidado as informações são transmitidas, o conhecimento e as decisões são tomadas adequadamente ao negócio.

Ao buscar uma certificação, a organização busca atender a demandas do mercado (CURKOVIC; PAGELL, 1999; LO et al., 2013; NEIROTTI; PAOLUCCI, 2009; TERZIOVSKI; POWER; SOHAL, 2003; STEVENSON; BARNES, 2002), mas também busca reduzir seus riscos - ao melhor controlar suas atividades - e aumentar seu desempenho. Esta equação não é simples e tem uma resposta em cada organização. Busca-se com esta pesquisa as características observadas em organizações de TI que se certificaram em ISO 20.000 para solucionar a equação. Como exemplos de pesquisas similares há o levantamento de organizações alemãs feito por Disterer (2009) e estudo aprofundado em organizações certificadas ISO 9.000 feito por Singh (2008). Para tornar possível a comparação entre elas, foram definidas variáveis comuns no contexto: mercado de atuação e modelo padronizado de governança de TI utilizado como referência.

\subsection{Organização da tese}

Capítulo 1: esta introdução;

Capítulo 2: a revisão bibliográfica é dividida em dois capítulos: este detalha os conceitos de risco e desempenho, propondo sua relação com a governança de TI; 
Capítulo 3: continuando a revisão bibliográfica, definição e modelos de referência de governança de TI, tendo como contexto o gerenciamento de processos e de serviços de TI, com foco no negócio e na estrutura das empresas prestadoras de serviço que serão objeto do estudo: fatores críticos de sucesso versus riscos versus competitividade, etc.; Capítulo 4: método de trabalho utilizado para levantamento sobre o contexto da pesquisa, referenciais teóricos, modelo de coleta de dados através de estudo de casos múltiplos e análise destes dados;

- Capítulo 5: resultados do levantamento realizado através de questionário com parte das organizações brasileiras certificadas ISO 20.000;

- Capítulo 6: estudos de caso, apresentando os dados coletados através das entrevistas com as empresas analisadas;

Capítulo 7: contém as análises dos resultados obtidos através das respostas ao questionário e entrevistas;

- Capítulo 8: contém as conclusões derivadas da análise de dados realizada conforme especificado no capítulo 4, coletados nos capítulos 5 e 6 e analisados no capítulo 7;

- $\quad$ Capítulo 9: referências utilizadas para a realização do estudo;

- $\quad$ Apêndice 1: modelo da carta convite;

- $\quad$ Apêndice 2: questionário utilizado na primeira fase de coleta de dados e respostas completas dos questionários da fase 1 ;

- $\quad$ Apêndice 3: uso de técnicas de análise multivariada sobre os dados obtidos nas fases 1 e 2 para validação de resultados;

- $\quad$ Apêndice 4: são detalhados os processos presentes nos requisitos de certificação ISO 20.000, utilizados como modelo canônico. 


\section{EQUACIONAMENTO DA RELAÇÃO RISCO VERSUS DESEMPENHO}

Este capítulo apresenta os conceitos de risco e desempenho utilizados na preparação e análise deste trabalho, embasando a construção dos instrumentos de pesquisa.

Partiu-se de uma visão do negócio da organização para a tecnologia da informação, de modo a entender a interação entre estas dimensões e fatores que as definem. Foram pesquisados na literatura trabalhos que trazem abordagem semelhante e contribuem para o universo de TI com aplicações práticas.

Para definir os conceitos a serem explorados, devem ser entendidos os contextos externo e interno à organização (FISCHER, 1989; XUE; LIANG; BOULTON, 2008). São apresentadas referências de literatura que exploram esses pontos, como classificações e aplicações no universo da tecnologia da informação. A partir destas referências, são identificados fatores relevantes para a definição de cada tema, que devem ser investigados nas etapas de coleta e análise de dados.

Esta conceituação também é abordada pelos modelos de governança de TI. Cobit (ISACA, 2012) parte desde a perspectiva do negócio até os indicadores dos processos de gerenciamento de TI. Apresenta um forte viés de redução de riscos e procura medir o desempenho através das métricas produzidas em cada objetivo de controle, dada sua origem em auditoria. ITIL (TAYLOR et al., 2007) apresenta muito foco nos processos que devem ser estabelecidos para controlar a operação de entrega de serviços de TI. Com este controle, o desempenho é medido através da eficácia e eficiência dos processos. O controle de riscos fica bastante evidenciado ao tratar da continuidade de serviços do negócio e gerenciamento da disponibilidade, bem como as avaliações necessárias no gerenciamento de mudanças durante sua fase de planejamento.

ISO 20.000 (ABNT, 2011) e ISO 38.500 (ABNT, 2009) tratam os temas dentro do ciclo de melhoria contínua, de modo que a organização deve avaliar constantemente a equação entre seu portfólio e sua entrega, para garantir desempenho adequado. 


\subsection{Risco}

Riscos podem ser definidos como a chance de que um evento interfira no atingimento de objetivos (COMMITTEE OF SPONSORING ORGANIZATIONS, 2004), ou ainda como o “impacto negativo do exercício de uma vulnerabilidade, considerando tanto a probabilidade quanto o impacto de sua ocorrência" (STONEBURNER; GOGUEN; FERINGA, 2002).

Os riscos são inerentes à natureza dos negócios e mercado em que uma organização está inserida. Uma empresa que atua no mercado de ações é intrinsecamente mais exposta ao risco que outra que lida com mercadorias (BENAROCH et al., 2007). Mesmo assim organizações encontram suas maneiras próprias de tratar riscos. Wilkin e Chenhall (2010) citam tipos de atitude da organização perante o risco:

- Evitar risco: não assumir contratos ou atividades diferentes das convencionais, que introduzem incertezas no dia a dia da operação;

- Reduzir/mitigar o risco: identificar e tratar os riscos, deixando claros os planos de ação a serem implantados para reduzir possíveis impactos frente a novas atividades;

- Compartilhar/transferir o risco: dividir os riscos com os clientes e parceiros da organização, ou mesmo transferi-los a outra organização, sem que responsabilidade ou possíveis penalizações contratuais sejam aplicáveis;

- Aceitar o risco: assumir eventuais impactos em nome de atender aos clientes e ganhar concorrências.

Muito comumente se vê em contratos de terceirização de serviços de TI um pensamento voltado à transferência de riscos (BAHLI; RIVARD, 2005), em que a organização prestadora passaria a ser integralmente responsabilizada pelo sucesso ou insucesso da operação de TI e consequente desempenho do negócio. Esta premissa leva a contratações equivocadas principalmente pela diferença de expectativas entre prestadores de serviços de TI e os contratantes. Os riscos não são completamente transferidos (PRADO; CRISTOFOLI; SCHMIDT, 2012), uma vez que a inteligência sobre o processo de negócio e sua ligação direta com os objetivos da organização continuam sob responsabilidade do gestor que contrata os serviços de TI. 
Os riscos, quando não mitigados, podem trazer consequências negativas de duas naturezas à organização (CHEN; ZHANG; LAI, 2009; MEIRELLES, 2012; Nikolic e Ruzic-Dimitrijevic, 2009):

Tangíveis: perda de receita, perda de produtividade (tempo dos profissionais, horasextras), número e volume de transações não realizadas ou concluídas, penalidades contratuais, multas regulatórias;

- Intangíveis: desgaste da imagem corporativa, perda de tempo de clientes, perda da confiança dos clientes.

O gerenciamento de riscos requer a ciência dos riscos pela alta administração, a adequada avaliação da tolerância ao risco da organização, a necessidade de atendimento a demandas regulatórias, a identificação da exposição a riscos significativos e o estabelecimento de responsabilidades (ISACA, 2009). Van Grembergen; de Haes e Guldentops (2004) colocam o gerenciamento do risco centrando-se na preservação do valor de negócios. Há vasta cobertura na literatura sobre gerenciamento de riscos, que não será explorada neste trabalho, uma vez que os fatores relevantes a este gerenciamento foram utilizados como insumos para a coleta e análise de dados desta pesquisa.

O fator localização geográfica também influi na atitude perante o risco. Fleury A. e Fleury M.T.L. (2012) apresentam um estudo sobre as organizações multinacionais brasileiras, destacando características que influenciam nestas decisões. Hofstede (2012) propôs um estudo originado nas diferenças entre profissionais da mesma organização localizados em países diversos. Para tanto, estabeleceu cinco fatores para medir tais diferenças, chamados de distância psíquica. Especificamente sobre riscos, definiu a repulsão ao risco (UAI), sendo a tolerância de uma sociedade ante a incerteza e ambiguidade. Esta característica pode ser comparada entre organizações, e entre uma organização e o país em que se encontra.

Para a organização de TI, avaliar as mudanças e planejá-las de maneira adequada são atividades fundamentais para evitar impactos negativos ao negócio. A governança corporativa trata das definições de estratégia da empresa, às quais a governança de TI deve estar alinhada. A análise não deve se limitar aos impactos que podem ser causados pela mudança, mas também aqueles relacionados à não execução da mudança: deixar de alterar regras de negócio, aplicar implantações de segurança ou conformidades regulatórias podem implicar em multas, sanções 
ou perdas de receita para a organização. Para Xue; Liang e Boulton (2008) a atitude de uma organização perante o risco interfere diretamente em suas características de investimento em tecnologia da informação.

Sobre gerenciamento de riscos de TI, foi feito um levantamento sobre o relacionamento entre os temas de governança, sendo considerados 70.137 artigos publicados entre 2009 e 2011, das bases Scopus, AiSEL e RA-USP. Estes foram pesquisados pelas palavras-chave em inglês ("technology governance", "corporate governance" e "risk management") e em português ("governança de TI", "governança corporativa" e "gerenciamento de risco"), de acordo com a base de publicação. Os resultados foram sintetizados na Tabela 1.

Tabela 1 - Levantamento de publicações sobre governança corporativa, governança de TI e risco.

\begin{tabular}{|c|c|c|c|}
\hline $\begin{array}{l}\text { Quantidade } \\
\text { de publicações }\end{array}$ & $\begin{array}{l}\text { Governança } \\
\text { Corporativa }\end{array}$ & $\begin{array}{l}\text { Governança } \\
\text { de TI }\end{array}$ & $\begin{array}{l}\text { Gerenciamento de } \\
\text { Riscos }\end{array}$ \\
\hline $\begin{array}{l}\text { Governança } \\
\text { Corporativa }\end{array}$ & 2.780 & 322 & 835 \\
\hline $\begin{array}{l}\text { Governança } \\
\text { de TI }\end{array}$ & - & 1.652 & 1.034 \\
\hline $\begin{array}{l}\text { Gerenciamento } \\
\text { de Riscos }\end{array}$ & - & - & 68.079 \\
\hline $\begin{array}{l}\text { Relacionamento } \\
\text { entre os três temas }\end{array}$ & \multicolumn{3}{|c|}{183} \\
\hline
\end{tabular}

O levantamento mostra interação significativa do gerenciamento de riscos com os modelos de governança (30,0\% em corporativa e 62,5\% em TI). Uma distorção inicial dos dados é dada pelo gerenciamento de riscos, uma vez que é uma disciplina utilizada em diversos outros campos das ciências, por isso sua alta incidência. Isto se ajusta ao buscar os artigos com palavras-chave em comum. 
Kobelsky; Hunter e Richardson (2008) apresentam riscos como eventos que podem levar a falhas de TI. Segundo sua classificação, os riscos podem ser dos seguintes tipos:

- $\quad$ Técnico: conhecimento dos profissionais não é adequado às atividades que precisam ser executadas;

- $\quad$ Projeto: especificação das atividades e definição das expectativas do cliente não foram suficientemente detalhados;

- $\quad$ Operacional: erros cometidos na execução das atividades de gerenciamento e operação dos serviços de TI;

- $\quad$ Política interna: conflitos entre diferentes áreas levam a problemas nos serviços de TI, seja por falta de colaboração, ou iniciativas concorrentes;

- $\quad$ Otimismo da gerência: que leva a subestimar potenciais problemas, desconsiderando a geração e acompanhamento de planos de mitigação.

Wilkin e Chenhall (2010) propõem, através de estudo sobre revisão de governança de TI, considerações fundamentais para entendimento do gerenciamento do risco de TI:

- Quais os tipos de risco?

- Quais as estratégias para gerenciar os riscos?

- Qual o papel da alta liderança perante o gerenciamento de riscos?

- $\quad$ Qual o papel da gerência perante o gerenciamento de riscos?

Alves e Cherobim (2004) apresentam riscos operacionais corporativos que afetam o desempenho das organizações. Observando a dependência das organizações sobre tecnologia da informação, sendo que nesta pesquisa são tratadas empresas cujo negócio-fim é TI, é possível estabelecer uma relação entre os riscos corporativos e de tecnologia, apresentada na Tabela 2.

Tabela 2 - Relacionamento entre riscos operacionais corporativos e de TI.

\begin{tabular}{|l|l|l|}
\hline Tipos de & Riscos corporativos & Riscos de TI \\
evento & & \\
\hline
\end{tabular}




\begin{tabular}{|c|c|c|}
\hline Fraudes & $\begin{array}{l}\text { Omissão intencional de posições, roubo por } \\
\text { empregados, e negociadores entrantes em uma } \\
\text { conta própria de empregado. }\end{array}$ & $\begin{array}{l}\text { Segurança da } \\
\text { informação, ISO } 27001 .\end{array}$ \\
\hline $\begin{array}{l}\text { Fraudes } \\
\text { Externas }\end{array}$ & $\begin{array}{l}\text { Roubo, falsificação, cheque sem fundos, dano } \\
\text { decorrente de fraude por computador. }\end{array}$ & $\begin{array}{l}\text { Ataques digit } \\
\text { e externos). }\end{array}$ \\
\hline $\begin{array}{l}\text { Práticas } \\
\text { empregatícias } \\
\text { e segurança } \\
\text { no ambiente } \\
\text { de trabalho }\end{array}$ & $\begin{array}{l}\text { Reclamações trabalhistas, questões de saúde } \\
\text { laboral e regras de segurança, atividades de } \\
\text { trabalho organizadas, reclamações por } \\
\text { discriminação, e obrigações gerais. }\end{array}$ & $\begin{array}{l}\text { Teletrabalho, legislações } \\
\text { específicas para centros } \\
\text { de serviço. }\end{array}$ \\
\hline $\begin{array}{l}\text { Clientes, } \\
\text { produtos e } \\
\text { práticas de } \\
\text { negócio }\end{array}$ & $\begin{array}{l}\text { Brechas fiduciárias, uso indevido de } \\
\text { informação confidencial de cliente, atividades } \\
\text { de negociação impróprias nas contas dos } \\
\text { bancos, lavagem de dinheiro, e venda de } \\
\text { produtos não autorizados. }\end{array}$ & $\begin{array}{l}\text { Manipulação indevida de } \\
\text { dados, erro de } \\
\text { processamento, ações } \\
\text { intencionais. }\end{array}$ \\
\hline $\begin{array}{l}\text { Danos a } \\
\text { ativos físicos }\end{array}$ & $\begin{array}{l}\text { Terrorismo, vandalismo, terremotos, incêndios } \\
\text { e enchentes. }\end{array}$ & $\begin{array}{l}\text { Ataques digitais (internos } \\
\text { e externos), falta de plano } \\
\text { de contingência. }\end{array}$ \\
\hline $\begin{array}{l}\text { Interrupção } \\
\text { dos negócios } \\
\text { e falhas de } \\
\text { sistemas }\end{array}$ & $\begin{array}{l}\text { Falhas de hardware e de software, problemas } \\
\text { de telecomunicações, interrupção no } \\
\text { fornecimento de energia. }\end{array}$ & $\begin{array}{l}\text { Gerenciamento da } \\
\text { Continuidade de Serviços } \\
\text { de TI. }\end{array}$ \\
\hline $\begin{array}{l}\text { Execução, } \\
\text { entrega }\end{array}$ & $\begin{array}{l}\text { Erros na entrada de dados, falhas na gestão de } \\
\text { colaterais, documentação legal incompleta, } \\
\text { acesso não consentido a conta de clientes, }\end{array}$ & $\begin{array}{l}\text { Falta de automatização } \\
\text { de processos, uso de }\end{array}$ \\
\hline
\end{tabular}




\begin{tabular}{|l|l|l|l|}
\hline gestão de & $\begin{array}{l}\text { desempenho indevido da contraparte não- } \\
\text { processos }\end{array}$ & fontes de informação \\
& cliente, disputa de fabricantes. & inadequadas.
\end{tabular}

FONTE: adaptado de Alves e Cherobim, 2004.

Em complemento, estudos apresentam riscos ao desempenho do ponto de vista interno à organização devido a falhas da infraestrutura de TI (HUANG et al., 2006) ou erros em entradas de dados, perdas de dados acidentais (ABU-MUSA, 2007). Do ponto de vista externo, Yeh e Chang (2007) apresentam um estudo sobre perdas devidas a ameaças de vírus e ataques de hackers contra a confidencialidade e privacidade de dados corporativos. Maizlish e Handler (2005) apontam a importância da segurança da informação e da estrutura de TI para avaliação dos riscos ao negócio.

Ao observar as referências estudadas, são definidos fatores que representam a análise de riscos para pesquisa, conforme apresentados na Tabela 3.

Tabela 3 - Fatores de risco para tecnologia da informação considerados nesta pesquisa.

\begin{tabular}{|c|c|c|c|}
\hline Contexto & Fator de risco & Descrição & Referências \\
\hline \multirow[t]{2}{*}{ Externo } & $\begin{array}{l}\text { Decisão sobre } \\
\text { Investimentos }\end{array}$ & $\begin{array}{l}\text { As decisões sobre os } \\
\text { investimentos em TI mostram } \\
\text { como a organização se comporta } \\
\text { perante o cenário competitivo e } \\
\text { exigências do mercado. }\end{array}$ & $\begin{array}{l}\text { de Haes e Van } \\
\text { Grembergen (2010); } \\
\text { Wilkin e Chenhall } \\
\text { (2010); Xue; Liang e } \\
\text { Boulton (2008); Lunardi } \\
\text { (2008); Hughes (2006). }\end{array}$ \\
\hline & $\begin{array}{l}\text { Segurança da } \\
\text { informação }\end{array}$ & $\begin{array}{l}\text { As perdas ocasionadas por } \\
\text { invasões, roubos e fraudes } \\
\text { causadas por agentes externos à } \\
\text { organização podem ser evitadas } \\
\text { por TI. }\end{array}$ & $\begin{array}{l}\text { Cobit (ISACA, 2012); } \\
\text { Wilkin e Chenhall } \\
\text { (2010); Lunardi (2008); } \\
\text { Hughes (2006); } \\
\text { Alves e Cherobim (2004); } \\
\text { Van Grembergen e de } \\
\text { Haes (2000). }\end{array}$ \\
\hline
\end{tabular}




\begin{tabular}{|c|c|c|c|}
\hline & $\begin{array}{l}\text { Continuidade } \\
\text { de serviços }\end{array}$ & $\begin{array}{l}\text { De acordo com a dependência do } \\
\text { negócio da TI, ações devem ser } \\
\text { tomadas para garantir a } \\
\text { continuidade dos serviços em caso } \\
\text { de ocorrência de desastres ou } \\
\text { falhas mais graves dos serviços. }\end{array}$ & $\begin{array}{l}\text { Cobit (ISACA, 2012); } \\
\text { ITIL (TAYLOR et al., } \\
\text { 2007). }\end{array}$ \\
\hline \multirow[t]{4}{*}{ Interno } & $\begin{array}{l}\text { Segurança da } \\
\text { informação }\end{array}$ & $\begin{array}{l}\text { As perdas ocasionadas por roubos } \\
\text { e fraudes causadas por agentes } \\
\text { internos à organização podem ser } \\
\text { evitadas por TI. }\end{array}$ & $\begin{array}{l}\text { Bulchand-Gidumal e } \\
\text { Melián-González (2011); } \\
\text { Alves e Cherobim (2004). }\end{array}$ \\
\hline & Operação de TI & $\begin{array}{l}\text { - Falhas de hardware e de software, } \\
\text { problemas de telecomunicações, } \\
\text { interrupção no fornecimento de } \\
\text { energia. } \\
\text { - A tecnologia necessária para a } \\
\text { mitigação de riscos estar presente } \\
\text { ou disponível. } \\
\text { - Falta de conhecimentos } \\
\text { específicos dos profissionais, seja } \\
\text { na nova tecnologia ou processos, } \\
\text { coloca em risco os serviços de TI. } \\
\text { - Interesses pessoais que podem } \\
\text { influenciar negativamente } \\
\text { utilização de melhores práticas de } \\
\text { governança de TI na prática do dia- } \\
\text { a-dia. }\end{array}$ & $\begin{array}{l}\text { Wilkin e Chenhall } \\
\text { (2010); Kobelsky; Hunter } \\
\text { e Richardson (2008); } \\
\text { Alves e Cherobim (2004). }\end{array}$ \\
\hline & $\begin{array}{l}\text { Atitude } \\
\text { perante o risco }\end{array}$ & $\begin{array}{l}\text { A estratégia adotada pela } \\
\text { organização para tratamento e } \\
\text { gerenciamento de riscos influencia } \\
\text { seus resultados. }\end{array}$ & Hofstede (2012). \\
\hline & $\begin{array}{l}\text { Salvaguarda de } \\
\text { ativos }\end{array}$ & $\begin{array}{l}\text { Os serviços de TI podem ser } \\
\text { prestados aos clientes através dos }\end{array}$ & Cobit (ISACA, 2012). \\
\hline
\end{tabular}




\begin{tabular}{|c|c|c|}
\hline & $\begin{array}{l}\text { ativos de TI, que devem ser } \\
\text { preservados. }\end{array}$ & \\
\hline $\begin{array}{l}\text { Tomada de } \\
\text { decisão } \\
\text { baseada em } \\
\text { informações }\end{array}$ & $\begin{array}{l}\text { Para que os processos sejam mais } \\
\text { maduros, é necessário que as } \\
\text { métricas e informações geradas } \\
\text { sejam utilizadas nas tomadas de } \\
\text { decisão da organização. }\end{array}$ & Cobit (ISACA, 2012). \\
\hline $\begin{array}{l}\text { Gerenciamento } \\
\text { das mudanças }\end{array}$ & $\begin{array}{l}\text { Dado que a mudança é uma } \\
\text { constante, seu controle é } \\
\text { importante para a manutenção } \\
\text { adequada das práticas, } \\
\text { especialmente ao se tratar de um } \\
\text { ambiente certificado em uma } \\
\text { norma de referência. }\end{array}$ & Cobit (ISACA, 2012). \\
\hline
\end{tabular}

\subsection{Desempenho}

Desempenho é a forma de medir se uma organização atingiu seus objetivos e é capaz de se sustentar como negócio (Maximiano, 2008), devendo ser avaliado através de métricas que estejam de acordo com os objetivos de negócio da organização (KOTLER; CASLIONE, 2009).

Em tecnologia da informação, há uma ampla discussão sobre o alinhamento de suas capacidades e entregas com os objetivos de negócio (CARVALHO; LAURINDO, 2006; NAIR, 2006; NEIROTTI; PAOLUCCI, 2007; YAO; LIU; CHAN, 2010). É preciso então diferenciar o relacionamento de TI com o negócio em organizações cujo negócio-fim é tecnologia da informação ou não.

No caso de TI não ser o negócio-fim da organização, a maior parte das publicações pesquisadas (ALVES et al., 2013) aponta como um fator fundamental o alinhamento dos objetivos e estratégia de TI com o negócio. O modelo apresentado por Henderson e Venkatraman (1993) é citado pelos autores das outras referências como modelo-base. 
Bhatt e Grover (2005) definem que o desempenho de TI leva a organização a obter vantagem competitiva. Melville; Kraemer e Gurbaxani (2004) apontam que é necessário observar fatores internos e externos à organização para estabelecer a relação entre TI e desempenho.

Uma diferença marcante entre as expectativas sobre tecnologia da informação e a realidade como contribui de fato aos negócios da organização é o contraponto entre inovação e redução de custos (GORDON, 2006). Espera-se de TI a capacidade de trazer inovação à organização, propondo novas maneiras de fazer negócios e gerar receita. Porém, ao analisar os investimentos de TI, nota-se uma realidade mais focada na redução de custos (XUE; LIANG; BOULTON, 2008). Esta diferença é apontada com dados por uma pesquisa que se repete ano a ano com CIO's, promovida pelo Gartner (2014).

Em organizações brasileiras, Zwicker et al. (2007) aplicam um modelo para medir o grau de informatização, para verificar a relação entre gastos de TI e o desempenho da empresa. Esta medição tem como base os seguintes fatores:

- $\quad$ Ativos de TI: como são controlados os equipamentos que são utilizados para a prestação de serviços de TI;

- $\quad$ Uso organizacional da TI: proporção das atividades da organização apoiadas por TI;

- $\quad$ Gestão da TI: processos adotados para controlar e medir as tarefas da operação de TI;

- Impactos da TI: impactos possíveis causados pela TI ao negócio, como indisponibilidade, perda de receita e imagem.

Em contraponto à importância estratégica de TI para o negócio em organizações cujo fim não é tecnologia da informação, Abrahamson (1996) e Collar e Lee (2002) questionam os modismos em tecnologia da informação, que, através de investimentos financeiros, de recursos e de tempo, não conseguem provar ao longo do tempo melhorias efetivas para a organização.

Brynjolfsson e Hitt (2003) questionam a necessidade do alinhamento entre TI e o negócio, uma vez que a TI é um meio para a obtenção de resultados, citando o paradoxo da produtividade de TI: há mais poder computacional, mas a produtividade não cresceu na mesma proporção. Carr (2003) critica a visão estratégica que os modelos padronizados de governança de TI buscam promover à tecnologia, sendo que ao final é apenas um apoio à organização. 
Estas visões sobre desempenho partindo de TI são criticadas pelos mesmos autores supracitados, uma vez que o desempenho da empresa acaba dependendo de diversos outros fatores que não podem ser simplesmente capturados em um modelo que observa somente a dimensão da tecnologia da informação. Naveh e Markus (2005) e Corbett e Kirsch (2001) apresentam com base no resultado de suas pesquisas que organizações que adotaram a norma obtiveram impacto sobre o desempenho da operação, mas que isto não necessária ou automaticamente levou ao aumento do desempenho do negócio.

De Haes e Van Grembergen (2010) defendem o alinhamento entre os objetivos de negócio e os de TI. Através da comparação de modelos padronizados de governança de TI, os autores concluem que há forte relação entre a implantação de modelos padronizados (Cobit e Val IT) e o atingimento de objetivos de negócio, bem como uma forte relação entre atingir objetivos de TI e atingir os objetivos de negócio. Desta forma, compradores de serviços de TI podem comparar os prestadores através de um modelo objetivo, sejam estes internos à organização ou empresas especializadas.

Para o caso de organizações cujo negócio-fim é TI, um modelo de maturidade como apresentado pelo Cobit permite a comparação entre as organizações. As definições apresentadas devem ser interpretadas segundo esta perspectiva: a adoção de processos visa garantir o controle dos riscos operacionais para entrega de resultados para o negócio fazendo com que TI tenha desempenho adequado.

Segundo Cobit (ISACA, 2012), o desempenho é medido através da monitoração das práticas de governança e todos os seus processos, relatos para os stakeholders e as saídas dos processos definidos em seu modelo. Especificamente sobre desempenho, este modelo apresenta dois processos: EDM2 (garantir a otimização do valor) e MEA1 (monitorar e avaliar o desempenho e conformidade).

Para Weill e Ross (2004), o desempenho da organização se reflete em objetivos declarados que possam ser medidos através de ações implantadas por TI. Singh (2008) define desempenho através de quatro itens: lucro, fluxo de caixa, demanda por produtos e market share. Love et al. (2005) cita o desempenho de TI como uma verificação se os projetos de tecnologia estão seguindo seu cronograma, orçamento e atingindo seus objetivos esperados, bem como se a infraestrutura de TI satisfaz as necessidades dos usuários. Gitman (2003) propõe a utilização de 
indicadores financeiros para avaliar o desempenho empresarial, através de dados contábeis e financeiros.

Em seu estudo, Bhatt e Grover (2005) buscam provar quatro fatores que influenciam no desempenho:

- Intensidade do aprendizado organizacional: como as práticas de melhoria contínua estão disseminadas, fazendo que experiências que a organização teve possam ser registradas e usadas no futuro como lições aprendidas;

- $\quad$ Experiência no negócio-fim de TI: conhecimento dos profissionais para a realização das atividades operacionais de TI;

- Estrutura de relacionamentos: ao promover o compartilhamento de riscos entre diferentes áreas da organização;

- $\quad$ Qualidade da infraestrutura de TI: nível de atualização e sua comparação com líderes de mercado dos equipamentos que são utilizados para prestar os serviços de TI.

Soh e Markus (2005) apresentam um processo que leva em conta três etapas para atingir o desempenho:

- Gastos em TI: seu controle provê melhorias através de finanças, entrega de valor aos acionistas e aumento da produtividade;

- $\quad$ Ativos de TI: seu controle permite melhorias através de novos produtos e serviços, redesenho de processos de negócio, flexibilidade, coordenação do negócio e melhor tomada de decisão;

- Impactos de TI: promove melhor utilização de TI por parte dos profissionais da organização e de seus clientes.

Singh (2008) fez um estudo baseado na norma ISO 9.001 para apresentar fatores que influenciam para se alcançar o desempenho de negócio adequado, classificados como internos ou externos à organização. Por ser uma norma de certificação, é possível estabelecer um paralelo entre o sistema de gestão da qualidade proposto na ISO 9.001 e o sistema de gerenciamento de serviços de TI apresentado pela ISO 20.000. Os fatores elencados por Singh (2008) são: 
- $\quad$ Políticas, planos e ações de gerenciamento: planejar e medir as práticas da organização para cumprimentos da demanda dos clientes, para que se possa obter o resultado desejado;

Foco nos clientes: priorizar e entender as demandas dos clientes, bem como gerenciar suas expectativas ao longo dos contratos;

- $\quad$ Empregados capazes: manter programas constantes de treinamento para os profissionais da organização;

- $\quad$ Fornecedores confiáveis: buscar prestadores de serviço que sejam capazes de cumprir os mesmos níveis de serviços e qualidade em acordo com o cliente final;

- Sistema de comunicação eficaz: comunicar constantemente para todos os níveis organizações os objetivos, requisitos dos clientes e práticas internas;

- Processos estáveis: processos estabelecidos formalmente na organização, publicados que tenham um período de estabilização, sem serem alterados a todo momento sem mesmo antes de medir sua eficácia. Quando modificados, são adequadamente comunicados;

- $\quad$ Entrega consistente de qualidade: busca da padronização da entrega através de processos prescritos pela organização;

- Clientes satisfeitos: medir a satisfação dos clientes e executar ação internas para garantir seu contentamento quanto aos serviços prestados.

Lunardi (2008) conduziu um estudo sobre organizações brasileiras que adotaram mecanismos formais de governança de TI, definidos pelo autor como grandezas que envolvem a estrutura, relacionamentos e processos. O desempenho organizacional, segundo o autor, está relacionado a indicadores financeiros, de rentabilidade e de mercado, como ROA (Return on Assets: Retornos sobre Ativos), ROE (Return on Equity: Retorno sobre o Patrimônio Líquido) e margem líquida.

Ao observar as referências estudadas, são definidos fatores que representam a análise de desempenho para pesquisa, conforme apresentados na Tabela 4, agrupados pelos contextos externo e interno conforme classificação proposta por Singh (2008). 
Tabela 4 - Fatores de desempenho para tecnologia da informação.

\begin{tabular}{|c|c|c|c|}
\hline Contexto & Fator de desempenho & Descrição & Referências \\
\hline \multirow[t]{4}{*}{ Externo } & $\begin{array}{l}\text { Recursos e processos } \\
\text { dos parceiros }\end{array}$ & $\begin{array}{l}\text { A interação com parceiros é um } \\
\text { dos fatores externos que } \\
\text { influenciam na qualidade da } \\
\text { entrega de serviços da } \\
\text { organização. }\end{array}$ & $\begin{array}{lr}\text { Bhatt e } r \text { Grover } \\
(2005) ; & \text { Melville; } \\
\text { Kraemer e Gurbaxani } \\
(2004) ; & \text { Singh } \\
(2008) . & \end{array}$ \\
\hline & Foco nos clientes & $\begin{array}{l}\text { A satisfação dos clientes é um } \\
\text { dos indicadores do desempenho } \\
\text { adequado da organização. }\end{array}$ & $\begin{array}{l}\text { Melville; Kraemer e } \\
\text { Gurbaxani (2004); } \\
\text { Singh (2008). }\end{array}$ \\
\hline & Escopo de tecnologia & $\begin{array}{l}\text { Como a organização se insere } \\
\text { no contexto externo ao utilizar } \\
\text { tecnologia da informação como } \\
\text { meio para prestar serviços. }\end{array}$ & $\begin{array}{l}\text { Henderson e } \\
\text { Venkatraman (1993). }\end{array}$ \\
\hline & $\begin{array}{l}\text { Competências } \\
\text { sistêmicas }\end{array}$ & $\begin{array}{l}\text { Como a organização é vista } \\
\text { pelo mercado para propor } \\
\text { soluções, sendo competente na } \\
\text { entrega de serviços de TI. }\end{array}$ & $\begin{array}{l}\text { Henderson e } \\
\text { Venkatraman (1993) }\end{array}$ \\
\hline \multirow[t]{3}{*}{ Interno } & $\begin{array}{l}\text { Demais recursos da } \\
\text { organização (não TI) }\end{array}$ & $\begin{array}{l}\text { As interações com outras áreas } \\
\text { (como jurídico e finanças) } \\
\text { influenciam a maneira de } \\
\text { atender os clientes. }\end{array}$ & $\begin{array}{l}\text { Melville; Kraemer e } \\
\text { Gurbaxani (2004). }\end{array}$ \\
\hline & $\begin{array}{l}\text { Conhecimento no } \\
\text { negócio de TI }\end{array}$ & $\begin{array}{l}\text { Entender como os benefícios } \\
\text { de TI são gerenciados para } \\
\text { gerar valor ao negócio. }\end{array}$ & $\begin{array}{l}\text { Cobit (ISACA, } \\
\text { 2012); } \\
\text { de Haes e Van } \\
\text { Grembergen (2010); } \\
\text { Wilkin e Chenhall } \\
(2010) \text {. }\end{array}$ \\
\hline & Clientes satisfeitos & $\begin{array}{l}\text { O foco nas necessidades dos } \\
\text { clientes determina como a } \\
\text { organização se estrutura para } \\
\text { responder a suas demandas. }\end{array}$ & Singh (2008) \\
\hline
\end{tabular}




\begin{tabular}{|c|c|c|}
\hline $\begin{array}{l}\text { Profissionais } \\
\text { competentes }\end{array}$ & $\begin{array}{l}\text { As competências dos } \\
\text { profissionais que executam as } \\
\text { atividades de TI são } \\
\text { importantes para a manutenção } \\
\text { da governança de TI e obtenção } \\
\text { de adequados resultados dos } \\
\text { serviços. }\end{array}$ & $\begin{array}{l}\text { Bulchand-Gidumal e } \\
\text { Melián-González } \\
\text { (2011); de Haes e } \\
\text { Van Grembergen } \\
\text { (2010); Henderson e } \\
\text { Venkatraman (1993); } \\
\text { Melville; Kraemer e } \\
\text { Gurbaxani (2004); } \\
\text { Nfuka e Rusu (2011); } \\
\text { Singh (2008); } \\
\text { Zwicker et al. (2007). }\end{array}$ \\
\hline $\begin{array}{l}\text { Sistemas de } \\
\text { comunicação eficazes }\end{array}$ & $\begin{array}{l}\text { O modo como a organização } \\
\text { captura, trata e divulga } \\
\text { conhecimento está relacionado } \\
\text { a suas práticas de melhoria } \\
\text { contínua. }\end{array}$ & $\begin{array}{lr}\text { Bhatt e } & \text { Grover } \\
(2005) ; & \text { Singh } \\
\text { (2008); } & \text { Senge } \\
\text { (2006). } & \end{array}$ \\
\hline Processos eficazes & $\begin{array}{l}\text { Os processos devem estar } \\
\text { consolidados e divulgados aos } \\
\text { profissionais para que possam } \\
\text { ser aplicados na prática. A } \\
\text { melhoria contínua contribui } \\
\text { para a interação entre o } \\
\text { processo prescrito e as } \\
\text { atividades executados no dia-a- } \\
\text { dia. }\end{array}$ & $\begin{array}{l}\text { Henderson e } \\
\text { Venkatraman (1993); } \\
\text { Singh (2008). }\end{array}$ \\
\hline $\begin{array}{l}\text { Saídas de qualidade } \\
\text { consistente }\end{array}$ & $\begin{array}{l}\text { As saídas dos processos } \\
\text { relacionados aos serviços de TI } \\
\text { são uma maneira de verificar o } \\
\text { desempenho dos processos de } \\
\text { negócio. }\end{array}$ & $\begin{array}{l}\text { Melville; Kraemer e } \\
\text { Gurbaxani (2004); } \\
\text { Singh (2008). }\end{array}$ \\
\hline $\begin{array}{l}\text { Políticas de } \\
\text { gerenciamento, }\end{array}$ & $\begin{array}{l}\text { Os investimentos em TI } \\
\text { determinam a manutenção ou } \\
\text { crescimento dos serviços, }\end{array}$ & $\begin{array}{l}\text { Cobit (ISACA, } \\
\text { 2012); Henderson e } \\
\text { Venkatraman (1993); }\end{array}$ \\
\hline
\end{tabular}




\begin{tabular}{|c|c|c|}
\hline $\begin{array}{l}\text { investimentos, planos } \\
\text { e ações }\end{array}$ & $\begin{array}{l}\text { preparando-os para as } \\
\text { demandas de mercado. }\end{array}$ & $\begin{array}{l}\text { Nfuka e Rusu (2011); } \\
\text { Wilkin e Chenhall } \\
\text { (2010); } \\
\text { (2008); }\end{array}$ \\
\hline $\begin{array}{l}\text { Definir um plano } \\
\text { estratégico para TI }\end{array}$ & $\begin{array}{l}\text { Verificar a importância relativa } \\
\text { do modelo de referência para a } \\
\text { organização, através dos } \\
\text { impactos de TI ao negócio. }\end{array}$ & $\begin{array}{l}\text { Bulchand-Gidumal e } \\
\text { Melián-González } \\
\text { (2011); Wilkin e } \\
\text { Chenhall (2010); Soh } \\
\text { e Markus (1995). }\end{array}$ \\
\hline Arquitetura & $\begin{array}{l}\text { A infraestrutura de TI é a base a } \\
\text { partir da qual a organização é } \\
\text { capaz de prestar os serviços de } \\
\text { TI. }\end{array}$ & $\begin{array}{l}\text { Bhatt e Grover } \\
\text { (2005); Bulchand- } \\
\text { Gidumal e Melián- } \\
\text { González (2011); } \\
\text { Soh e Markus (1995). }\end{array}$ \\
\hline
\end{tabular}

\subsection{A relação risco versus desempenho em governança de TI}

Comparando-se as definições de risco e desempenho descritas anteriormente, nota-se que durante a busca pelo cumprimento dos objetivos, ocorrências podem causar impactos indesejados sobre as atividades e comprometer os resultados. Assim, controles são implementados através dos processos para definir as atividades que possam levar a organização a atender a seus clientes de modo consistente, aferir o desempenho, evitar a exposição a riscos de maneira proativa e saber como atuar em caso destes incidentes.

Ao observar as características descritas sobre risco e desempenho em TI, compreendida no contexto em que a tecnologia da informação apoia o negócio na obtenção de seus objetivos, os fatores apresentados nos itens anteriores podem ser pesquisados para demonstrar a relação entre estes dois conceitos (CHATZOGLOU; DIAMANTIDIS, 2009). Kobelsky; Hunter e Richardson (2008) concluíram em seu estudo que quanto maior o risco uma organização de TI corre, maior é o resultado esperado. 
Do ponto de vista financeiro, Lai e Samad (2011) apresentam a necessidade do gerenciamento de riscos para a obtenção de desempenho organizacional adequado. Seguindo a teoria financeira neoclássica, os autores determinam o valor da organização de acordo com seu tratamento a risco e o retorno que geram a seus acionistas, encontrando uma relação de causalidade: gerenciamento de riscos como causa do desempenho dos negócios.

Desempenho e riscos definem uma relação de equilíbrio dinâmico. Em complemento, o ponto de equilíbrio é onde se colocam os processos: quanto maior o controle exercido pela organização, menores os riscos a serem assumidos e espera-se um desempenho menos expressivo. Há uma fronteira de eficiência defendida por pesquisadores na área financeira (BELMONT, 2004) e administrativa (SINGH, 2008; TALLON; PINSONNEAULT, 2011): se há controle de riscos exagerado, o desempenho pode piorar ao contrário do esperado pois limita demais as atividades dos profissionais. Por outro lado, a liberdade exagerada de práticas faz com que os riscos sejam elevados em demasia, prejudicando os negócios.

Com esta delimitação de objetivos e vantagens, pode-se compreender que não se trata da busca de uma relação de equilíbrio entre risco e desempenho, tais quais duas grandezas em uma balança. O que se tem é uma relação de proporcionalidade entre estas dimensões, ajustada pela governança de TI que exerce controle com seus processos prescritos.

Para efeitos desta pesquisa, ao filtrar organizações que atuam no mesmo mercado e são certificadas pela mesma norma, espera-se encontrar fatores sobre a relação entre risco e desempenho, dada a teoria financeira da fronteira da eficiência (BELMONT, 2004).

\subsection{O indivíduo e a relação risco versus desempenho}

Os processos, como ponto de regulação da relação dinâmica entre risco e desempenho, introduzem pressão sobre os indivíduos na organização. A prescrição de processos pela organização visa diminuir a dependência do conhecimento individual em favor da consistência de entrega. 
Conforme Fischer (1989), o processo de mudança deve ser analisado levando em conta o contexto onde acontece: a cultura organizacional e suas relações de poder. Os pontos a serem considerados sobre este contexto, na análise voltada ao sistema de governança, são a atitude perante o risco (HOFSTEDE, 2012) e como as responsabilidades são distribuídas (WEILL; ROSS, 2004). Com relação à cultura organizacional, Hind (1996) verifica em seu estudo que modelos de referência, como ISO 9.000, apresentam uma tendência de não encorajar mudanças, uma vez que trata fortemente do assunto do controle sobre as mesmas. Características como flexibilidade e inovação são desvalorizadas, pois naturalmente levam à não-conformidade, fator relevante dado o caráter de auditoria embutido em uma norma.

As pessoas acabam encorajadas a manter o modo como estavam acostumadas a trabalhar, pois entendem que isto deveria estar refletido no sistema de gestão, e não o contrário. Bazerman e Moore (2010) tratam deste ponto através do estudo de vieses: a tendência natural dos profissionais, individualmente ou em grupo, é manter a maneira atual de execução de atividades, porque "assim está bom o suficiente".

Hind (1996) conclui que é preciso haver na cultura organizacional uma série de fatores que devem ser equilibrados para que a aplicação de modelos de referência possa ser bem sucedida:

- $\quad$ Flexibilidade x estrutura;

- $\quad$ Controle x inovação;

- $\quad$ Foco interno x externo;

- $\quad$ Ação x harmonia.

Estas interações entre o profissional e a organização são relações de poder (FISCHER, 1989), que incluem os fatores citados acima. Estas relações estão presentes nas organizações e se mostram através dos processos de tomada de decisão (KO; FINK, 2010; LUCIANO; BECKER; TESTA, 2012; MOHAMED et al., 2012). As decisões em TI podem ser dos seguintes tipos, segundo Weill e Ross (2004):

- De princípios: tomadas em alto nível, como direções a serem seguidas;

- De arquitetura: integração lógica do software, hardware e outras soluções utilizadas para a prestação de serviços de TI;

- De infraestrutura: definindo a capacidade de TI da organização; 
- $\quad$ Sobre necessidade de aplicações de negócio: especificando se serão desenvolvidas internamente ou buscando soluções de mercado;

- Sobre investimentos e priorização: quando e em que serão aplicados os recursos financeiros para TI.

O indivíduo é o executor dos processos prescritos, sendo responsável por realizar as atividades que visam os resultados da organização, ao mesmo tempo em que é pressionado para atuar em conformidade com os requisitos estabelecidos nos processos.

Para efeitos desta pesquisa, o profissional é considerado um recurso padrão, portanto competente, que se não estiver disponível, precisa ser obtido (formado, treinado, recrutado no mercado e motivado), e quando disponível deve seguir os processos prescritos. O profissional padrão é aquele que possui os conhecimentos, habilidades e motivações, inclusive financeiras, necessárias para executar as operações ou tarefas sob sua responsabilidade, de acordo com os processos normatizados pela organização.

A colaboração é relacionada à interação entre os indivíduos: como se associam, quais são as trocas envolvidas para realizar, em conjunto, as atividades, o trabalho e, idealmente no desejo do gestor, atingir resultados (BECK; BECK-GERNSHEIN, 2002). Para o indivíduo o trabalho é ao mesmo tempo identidade e fonte de conflitos.

Sua relação com a sociedade está baseada em sua atividade profissional (JAMESON, 2011) o que lhe confere atributos coletivos e individuais: o modo como é visto pelos outros e a maneira como pode se compreender. Os conflitos surgem a partir do momento em que o indivíduo se vê forçado a ceder em suas convicções e prioridades pessoais para se adequar ao meio em que estará inserido.

Seyle e Swann Jr. (2007) citam que as mudanças, principalmente aquelas que ocorrem em ritmo rápido, são um dos grandes agentes estressores que afligem as pessoas. Toffler (1970) denomina a "inaptabilidade dos indivíduos" a esse ritmo intenso de mudanças como "choque de futuro": sendo a sensação de estar diante de um futuro que vem de encontro, cada vez mais rápido, ao presente e não havendo forma de detê-lo. Assim, os processos de adaptação se tornam intermináveis, juntamente com apreensão, medo e ânsia de estabilidade (DIAS, 2008). Este conceito se aplica ao contexto de tecnologia da informação, uma vez que as mudanças são constantes e velozes. 
Pelos trabalhos pesquisados em literatura, nota-se que ainda há uma carência referente a detalhamentos sobre os recursos humanos (ABIB; HOPPEN; RIGONI, 2012; LUCIANO; BECKER; TESTA, 2012; PIRSON; TURNBULL, 2011). Mesmo assim, é possível notar que o gerenciamento por processos, trazido pela adoção de um modelo padronizado de governança de TI, exerce pressão da organização sobre os indivíduos. Sobre poder e controle, a definição, estabelecimento e manutenção de processos dentro da organização possuem uma conotação de controle do líder sobre o liderado. Tal controle é explicitado uma vez que os processos são definidos e implantados na organização. Espera-se que os profissionais os sigam conforme prescrito.

Para observar estas competências, utiliza-se o conceito de empowerment como a liberdade na habilidade de decidir e cumprir os compromissos (FORRESTER, 2000; JOHNSTON, 2010). Um modelo voltado a esta observação é proposto por Elmes; Strong e Volkoff (2005), permitindo a relação entre vontade e conformidade, apresentado na Figura 3.

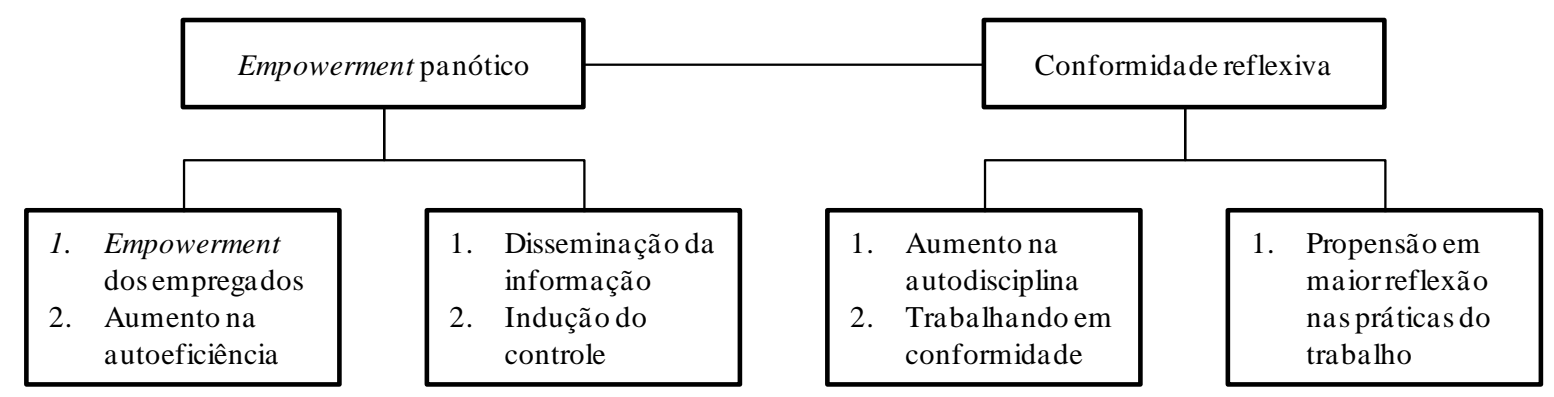

Figura 3 - Modelo proposto para detalhamento de vontade e conformidade. FONTE: Elmes; Strong e Volkoff (2005).

O controle panótico se refere ao exercício do poder, partindo de uma ação disciplinar externa para uma operação interna de construção de identidade individual. O que se busca é que a relação de poder, ao se ter empowerment do profissional, possa fazer com que o processo reflita não posse do poder do líder somente, mas o seu exercício pelo profissional.

A conformidade reflexiva é definida pela conformidade através da visibilidade da informação. Uma vez explicitada, ao se documentar e implantar processos, as pessoas buscam atender às especificações (KO; FINK, 2010). Os próprios profissionais sentem a preocupação com o 
aperfeiçoamento do trabalho, uma vez que se sentem empowered. Do mesmo modo, implica que as pessoas ao refletirem sobre sua execução, possam criticá-la e sugerir mudanças.

As teorias da ação racional (TRA) mostram como características do indivíduo com relação ao ambiente em que está inserido podem explicar seu comportamento. Estas são: crenças, avaliação, conhecimento normativo e motivação para conformidade (FISHBEIN; AJZEN, 2010). Os estudos realizados por Southey (2011) e Ghobakhloo; Zulkifli e Aziz (2010) apresentam características entre as relações de poder da liderança e dos profissionais, a partir da análise a partir do modelo TRA para prever comportamentos num ambiente com processos e práticas prescritas pela liderança, enquanto se agrega poder ao indivíduo através de suas características que o leva à tomada de decisões.

Com base no estudo de Decoster (2008), é possível focar a análise em alguns aspectos de comportamento voltados às relações de poder, conforme Figura 4.

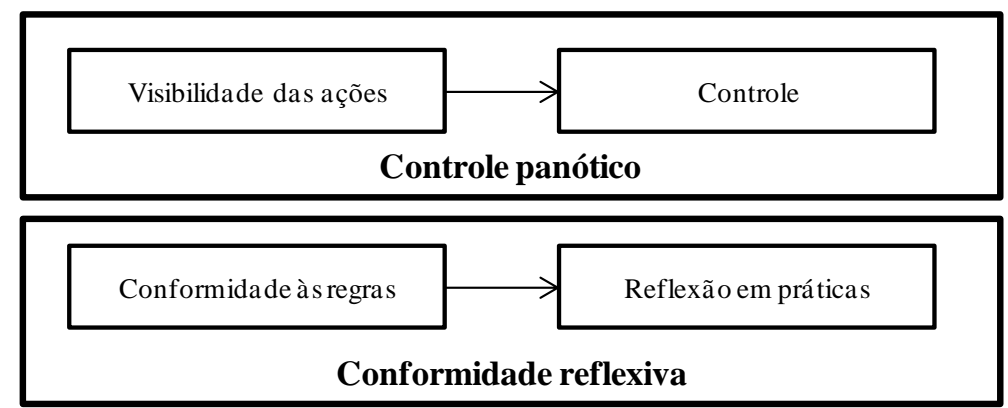

Figura 4 - Modelo adaptado para estudo do comportamento dos profissionais com relação aos processos organizacionais.

FONTE: adaptado de Decoster, 2008. 


\section{GOVERNANÇA DE TI}

Este capítulo apresenta as definições encontradas em literatura de referência para governança de TI.

Como as referências são fortemente apoiadas em processos e na prestação de serviços, são apresentados os modelos padronizados de governança de TI encontrados em literatura. Há diversos modelos para governança e gerenciamento de processos de tecnologia da informação disponíveis. Sua adoção varia ao redor do mundo (ABU-MUSA, 2008; ALI, 2006; BART; TERUEL, 2010; LO et al., 2013; RUZEVICIUS; ADOMAITIENE; SIRVIDAITE, 2004; TERZIOVSKI; POWER; SOHAL, 2003; GUSTAFSSON et al., 2001; LEE; PALMER, 1999; SAMSON; TERZIOVSKI, 1999), mas seus objetivos se assemelham: definir controles para minimizar risco e otimizar desempenho dos serviços de TI.

Implantar e manter modelos de governança promove uma série de mudanças na organização, que devem ser tratadas de maneira estruturada para promover o sucesso destes projetos. Portanto, conhecer as particularidades e dimensões envolvidas em uma mudança se torna fundamental para a criação de um modelo de análise.

Especificamente no Brasil, há maior adoção de ITIL e Cobit (CERIONI; BUZO; SHIBATA, 2014; ALVES et al., 2013; MEIRELLES, 2012; LIMA; RESENDE; HASENCLEVER, 2000) pelas organizações. A norma ISO 20.000 foi escolhida como modelo canônico de governança de TI para esta pesquisa, uma vez que apresenta as práticas em formato de requisitos certificáveis. Isto ajuda em sua utilização como referência de comparação entre as empresas certificadas, uma vez que todas precisaram cumprir seus requisitos mínimos para conformidade com as auditorias.

Nesta seção são apresentadas as referências ITIL e Cobit, suas possíveis interações e os requisitos da norma ISO 20.000. Em complemento é discutido o equilíbrio entre as dimensões propostas na introdução: desempenho e risco, uma vez que deve determinar o nível de investimento que as organizações podem dedicar aos modelos de referência de governança de TI. 


\subsection{Definição}

Para uma perspectiva histórica, utilizam-se palavras de Descartes (2006) para definir governança: "um grande número de leis normalmente fornece desculpas ao vício, então um governo é muito melhor ordenado quando, tendo algumas poucas leis, elas são muito bem cumpridas". De modo amplo, governança é um sistema de alocação de responsabilidades e controle (GUERRA; FISCHMANN; MACHADO FILHO, 2009; MEIRELLES, 2012).

Partindo da perspectiva do negócio para as particularidades de tecnologia da informação, buscase compreender como a distribuição de responsabilidades sobre as decisões de gerenciamento de TI contribuem para o adequado desempenho do negócio, através da prestação de serviços de TI. Conforme apresentado na Tabela 1, estudos foram realizados mostrando a relação entre governança corporativa e de TI.

Foram coletadas definições de governança de TI apresentadas em livros e artigos de publicações especializadas nas áreas de TI e Administração. As definições foram registradas com seu país de origem porque o contexto do país deve ser levado em conta nestas análises (MELVILLE, 2004).

Weill e Ross (2004), dos EUA, definem governança de TI como a especificação dos direitos decisórios e do framework de responsabilidades para estimular comportamentos desejáveis na utilização da TI.

Simonsson e Johnson (2005), com base em estudo na Suécia sobre 60 organizações, descrevem governança de TI como a preparação, o desenvolvimento e a implantação de decisões sobre metas, processos, pessoas e tecnologia em nível tático e estratégico.

ITGI - Information Technology Governance Institute - (2006), nos EUA a colocam como liderança, estruturas organizacionais e processos que buscam garantir que a TI sustente e aprimore os objetivos e a estratégia da organização, sendo a Governança de TI de responsabilidade dos executivos e da alta direção. 
IDC em Portugal (DUFFY, 2008) coloca a governança de TI como tendo a preocupação com a entrega de valor ao negócio e mitigação de riscos, garantindo que:

TI está alinhada com o negócio, permite ao negócio executar suas atividades e maximiza os seus benefícios (incluindo lucros);

- $\quad$ Recursos de TI são usados de modo responsável, e riscos relacionados à TI são gerenciados adequadamente e custos são reduzidos.

Van Grembergen e de Haes (2008) da Bélgica, definem governança de TI como liderança, estruturas organizacionais e processos que garantam que a TI mantém e amplifica a estratégia e objetivos da organização.

Fernandes e Abreu (2008), no Brasil, descrevem que a governança de TI direciona as decisões de TI, compartilhando com outros gestores dentro da organização. Estabelece regras, estrutura organizacional e processos que determinam a utilização de TI pelos usuários finais, departamentos, divisões, unidades de negócio, fornecedores e clientes, determinando como os serviços de TI devem ser fornecidos pela organização.

- $\quad$ Garante o alinhamento entre negócio e TI (estratégia e objetivos);

- Garante a continuidade dos negócios contra interrupções e falhas, enquanto mantém e gerencia serviços de aplicações e infraestrutura;

- $\quad$ Garante alinhamento entre TI e as regulamentações.

Carvalho (2009), também no Brasil, coloca-a como mecanismo de acompanhamento e avaliação da execução do Plano Estratégico de TI, fundamental para o seu sucesso, viabilizando a realização dos ajustes necessários em resposta ao dinamismo do mercado e da própria organização.

Albertin e Albertin (2010), no Brasil, definem-na como modelo de gestão, integrante da governança corporativa e da administração da TI, alinhado às estratégias, objetivos e metas organizacionais, que tem como função definir as diretrizes e efetivar o processo de decisão da TI, buscando uma entrega de valor, excelência operacional e otimização de resultados coerentes com as aspirações do negócio.

São diferentes pontos de vista para a definição de governança de TI, bem como os modelos padronizados. A partir das definições analisadas, notam-se alguns pontos comuns. A 
estruturação da tomada de decisões precisa ser compreendida mostrando a partir de quais áreas partem as autorizações para investimentos em tecnologia da informação. Estes direitos refletem como o desempenho das atividades de TI e os riscos são controlados dentro da organização, sendo alvo dos controles prescritos nestes modelos de referência. Outro ponto comum é a necessidade de gerar valor ao negócio, principalmente a partir dos elementos estabelecidos para relacionar as atividades de TI com o objetivo fim das organizações, principalmente através de controles e indicadores.

Como pontos divergentes, a prescrição de processos de modo detalhado é discutida. Cobit (ISACA, 2012) coloca a definição dos objetivos de controle que possam guiar as medições que precisam ser extraídas da operação de TI relacionando-a ao negócio, ao invés de ter que descrever os detalhes das atividades, ao contrário do apresentado em ITIL. Outro ponto divergente é que, apesar da como o processo de tomada de decisões está estruturado nas empresas, não é clara sua relação com a liderança formal dentro da organização quanto à tecnologia da informação. Há a necessidade de envolvimento da alta direção, mas não necessariamente ter as decisões contidas somente por uma área ou divisão especializada: as decisões e autoridades sobre os investimentos em tecnologia podem partir diretamente das áreas demandantes.

A governança de TI se apoia num tripé formado por processos, recursos tecnológicos e pessoas (Powell e Dent-Micallef, 1997; WEILL; ROSS, 2004), complementada pela estruturação sobre quatro pilares segundo ITIL (TAYLOR et al., 2007), com base nos quatro P's de marketing (KOTLER; CASLIONE, 2009): pessoas, parceiros, produtos e processos. Ao relacionar esses conceitos, define-se o tripé para análise:

- $\quad$ Processos: formalização das atividades a serem realizadas, seja operacionalmente ou para controles estratégicos e gerenciais, incluindo papéis e responsabilidades para sua execução;

- Recursos tecnológicos: componentes de hardware, software, sistemas de telecomunicações e de gestão de dados e informações, utilizados para guarda, geração e uso da informação e do conhecimento (CARVALHO, 2009);

- Pessoas: responsáveis pelo planejamento, operação, manutenção e utilização da tecnologia da informação, preenchendo os papéis prescritos pelos processos. São aqueles que recebem e geram seus resultados, divididos em papéis, que por sua vez são mapeados nos 
processos. Do ponto de vista interno da organização prestadora de serviços de TI, devem possuir as competências necessárias para entender as necessidades do negócio, internalizá-las e implantá-las sobre uma base de recursos tecnológicos, tornando as atividades mais eficientes.

O desafio da governança de TI é tratar de maneira equilibrada estes três pilares. Caso se invista somente em processos e tecnologia, faltam competências das pessoas para operá-las ou processos determinando como se relacionam com o negócio da empresa. Se o investimento é concentrado em processos, podem faltar sistemas para automatizar atividades repetitivas, ou que podem sobrecarregar as pessoas, aumentando a taxa de erros. Afinal é preciso considerar que os resultados do negócio e as atividades operacionais são atingidos e executados para e pelas pessoas.

Conceitualmente, governança de TI e gerenciamento de TI são distintos: governança trata de quem toma cada tipo de decisão, quem executa e quem é responsável, de forma alinhada à estratégia do negócio para atender a demandas atuais e futuras do negócio internamente e aos clientes do negócio externamente, enquanto o gerenciamento refere-se à entrega de serviços e produtos de TI, visando atender a demandas atuais, com foco interno.

Dadas as referências de embasamento, é proposta uma definição de governança de TI, incorporando os conceitos de risco e desempenho, que é seguida ao longo desta pesquisa:

- Governança de TI é o meio pelo qual uma organização de TI é dirigida, tratando de direitos de decisão, responsabilidades e mecanismos de monitoramento sobre pessoas, processos e tecnologias. Seu grande objetivo é o alinhamento estratégico da TI com o negócio, a avaliação e o gerenciamento de riscos da TI e a melhoria contínua, otimizando os investimentos em pessoas, processos e tecnologias.

Cobit (ISACA, 2012) também trata esta diferenciação: governança são todos os meios e mecanismos que garantem que múltiplas partes interessadas em uma organização tenham uma maneira organizada para: avaliar condições e opções; definir a direção; e monitorar a conformidade, desempenho e progresso com relação aos planos para satisfazer objetivos corporativos específicos. Na maioria das empresas, é responsabilidade do corpo de diretores, sob liderança do CEO e chairman. 
Gerenciamento é a maneira sensata e monitorada de usar os meios (recursos, pessoas, processos, práticas, etc.) para alcançar um determinado fim. É um instrumento através do qual o corpo de governança atinge resultados e objetivos. Gerenciamento trata de planejamento, construção, organização e controle das atividades operacionais alinhadas à direção determinada pelo corpo de governança.

As motivações das organizações para adoção de modelos padronizados de governança de TI foram pesquisadas na literatura e agrupadas na Tabela 5, segundo as cinco forças de Porter (MAXIMIANO, 2008), complementadas por uma perspectiva interna à organização prestadora de serviços de TI (SINGH, 2008).

Tabela 5 - Agrupamento de motivações para adoção de modelos padronizados de governança de TI.

\begin{tabular}{|c|c|}
\hline Força & Descrição \\
\hline Novos entrantes & $\begin{array}{l}\text { - Grandes problemas financeiro-administrativos (como } \\
\text { Enron, Worldcom, Parmalat), que motivaram o } \\
\text { aumento de práticas de governança corporativa e } \\
\text { consequente aumento pela procura de modelos } \\
\text { padronizados de governança de TI (CLARKE, 2004). } \\
\text { - Certificação em ISO 20.000, vista como um } \\
\text { diferencial e barreira a novos entrantes, uma vez que } \\
\text { a prestadora de serviços de TI a apresenta como } \\
\text { diferencial. }\end{array}$ \\
\hline Fornecedores & $\begin{array}{ll}\text { - } & \text { Redução de riscos. } \\
\text { - } & \text { Melhoria desempenho. }\end{array}$ \\
\hline Clientes & $\begin{array}{l}\text { - } \quad \text { Redução de riscos, ao terceirizar com uma } \\
\text { organização especializada. } \\
\text { - } \quad \text { Maior qualidade e menor custo de serviços. } \\
\text { - Mercado endereçável. }\end{array}$ \\
\hline Produtos substitutos & $\begin{array}{l}\text { - Serviços e modelos de negócio que alteram a forma } \\
\text { de consumir tecnologia da informação (ex.: } \\
\text { computação em nuvem). }\end{array}$ \\
\hline
\end{tabular}




\begin{tabular}{|l|l|}
\hline Concorrentes & - Preços e competitividade. \\
& $-\begin{array}{l}\text { Diferenciação por utilizar modelo de referência } \\
\text { conhecida. }\end{array}$ \\
\hline Perspectiva interna & - Redução de custos. \\
& - Dentro de um mesmo grupo (seja em regiões ou países \\
& diferentes), empresas similares com processos \\
& diferentes de trabalho. \\
\hline
\end{tabular}

Cobit (ISACA, 2012) apresenta vantagens ao se adotar governança de TI, já adaptadas às organizações prestadoras de serviços de tecnologia da informação. Na Tabela 6 estas são mostradas, com um comentário crítico adicionado pelo autor desta pesquisa.

Tabela 6 - Vantagens da adoção de modelo padronizado de governança de TI, segundo Cobit (ISACA, 2012).

\begin{tabular}{|l|l|}
\hline Vantagem & Comentário crítico \\
\hline $\begin{array}{l}\text { Serviços entregues por TI estão } \\
\text { negócio. }\end{array}$ & $\begin{array}{l}\text { Em organizações cujo negócio-fim é a prestação de } \\
\text { serviços de TI, deve-se buscar alinhamento com os } \\
\text { objetivos do cliente final, para que estes possam apoiar sua } \\
\text { realização. }\end{array}$ \\
\hline $\begin{array}{l}\text { Processos de TI são } \\
\text { padronizados e automatizados. }\end{array}$ & $\begin{array}{l}\text { Desta forma a organização prestadora de serviços pode } \\
\text { ganhar em escala para a realização de suas atividades. } \\
\text { Porém permitem menor grau de flexibilidade ante } \\
\text { necessidades de customização dos clientes. }\end{array}$ \\
\hline $\begin{array}{l}\text { Modelo geral e holístico para os } \\
\text { processos de TI, unificando-os. }\end{array}$ & $\begin{array}{l}\text { Estabelece uma linguagem comum dentro da organização, } \\
\text { e desta para o cliente, para tratar as atividades, ganhando } \\
\text { produtividade e evitando erros operacionais. }\end{array}$ \\
\hline $\begin{array}{l}\text { Sistema de gestão de qualidade } \\
\text { específico para TI. }\end{array}$ & $\begin{array}{l}\text { Como parte do credenciamento como referência externa } \\
\text { que pode ser usada por clientes para comparar diferentes } \\
\text { prestadores de serviços de TI, de acordo com suas } \\
\text { qualificações. }\end{array}$ \\
\hline
\end{tabular}




\begin{tabular}{|l|l|}
\hline $\begin{array}{l}\text { Fusões e aquisições acontecem } \\
\text { com impacto em TI. }\end{array}$ & $\begin{array}{l}\text { Caso haja acordos de níveis de serviço estabelecidos, com } \\
\text { linguagem comum, a transição e adaptação de processos e } \\
\text { práticas são facilitadas. } \\
\text { As decisões de clientes pela terceirização de serviços de TI } \\
\text { também devem ser baseadas em níveis de serviços, } \\
\text { evitando impactos e perdas devidas a falta de alinhamento } \\
\text { com as necessidades do negócio do cliente. }\end{array}$ \\
\hline $\begin{array}{l}\text { Iniciativas que ajudem a } \\
\text { controlar os custos de TI são } \\
\text { desejáveis nas organizações. }\end{array}$ & $\begin{array}{l}\text { Os processos são fortemente orientados a controles e } \\
\text { acabam atendendo ao requisito mais imediato dos gestores } \\
\text { com relação à TI: redução de custos, que leva a maior } \\
\text { competitividade do prestador de serviços de TI. }\end{array}$ \\
\hline $\begin{array}{l}\text { Conformidade com } \\
\text { requerimentos externos, tais } \\
\text { como regulamentos, } \\
\text { organizações, e governo. }\end{array}$ & $\begin{array}{l}\text { Ao se orientar por processos a organização se prepara para } \\
\text { conformidade e controle. Assim sendo, outras } \\
\text { regulamentações podem ser mais facilmente adaptadas às } \\
\text { práticas da organização. Porém, da mesma maneira, } \\
\text { causam processo de mudança que precisa ser incorporado } \\
\text { à organização para atender requisitos dos clientes. }\end{array}$ \\
\hline $\begin{array}{l}\text { Mudanças importantes na } \\
\text { Organtendimento do impacto de TI ao negócio e o caminho } \\
\text { inverso são fundamentais para a adequada administração } \\
\text { organização. Mais do que o alinhamento citado } \\
\text { anteriormente, o ponto mais crítico é a visão holística da } \\
\text { organização e sua dependência da tecnologia da } \\
\text { informação. }\end{array}$ \\
\hline
\end{tabular}

\subsection{Histórico da governança de TI}

A história dos modelos padronizados de governança de TI passa pela própria natureza dos departamentos ou áreas de TI das organizações. Nota-se no final da década de 1960 o início da utilização da informática para automatização de processos empresariais (TURBAN; RAINER JR.; POTTER, 2005). O principal objetivo da aplicação da TI, nascida na área financeira, era aumentar o desempenho e diminuir erros em processamento de dados. 
Com isto, foram criados nichos de profissionais que detinham o conhecimento técnico necessário para especificar e comprar as máquinas, programá-las e delas retirar os resultados dos processos. O processamento era essencialmente centralizado, sendo que os processos e os administradores ficavam concentrados sobre os equipamentos principais.

Com o avanço tecnológico e o barateamento dos processadores e componentes, a computação e o poder de processamento foram se aproximando do usuário final, descentralizando seu controle. As exigências e requerimentos sobre a infraestrutura da rede também começaram a crescer rapidamente. As ferramentas de desenvolvimento de software foram sendo simplificadas, fazendo com que áreas anteriormente usuárias passassem a criar sistemas de informação paralelos e sob sua própria gestão.

Em 1998, ITGI foi fundado com o propósito de conduzir pesquisas sobre a crescente área de governança de TI. Inicialmente o foco se deu em processos, controles e níveis de maturidade do Cobit (ITGI, 2006).

No final da década de 1990 e durante os anos 2000 vê-se a forte tendência de terceirização dos serviços de TI para empresas especializadas (PRADO; CRISTOFOLI, 2012; PRADO; CRISTOFOLI; SCHMIDT, 2012). A terceirização completa (full outsourcing) levou organizações a passarem o controle de suas operações de tecnologia para outras empresas.

Porém contratar um prestador especializado de serviços de TI não significa livrar-se do problema da gestão da tecnologia. Pelo contrário: seus direcionamentos e atenção a níveis de serviço que sejam compatíveis com as necessidades do negócio aumentam em importância, exigindo um diferente perfil dos gestores de TI (BAHLI; RIVARD, 2005). Este perfil inclui o gerenciamento dos contratos, ao invés de um profissional altamente especializado no desenho e especificação de tecnologia (GARTNER, 2014; PRADO; CRISTOFOLI; SCHMIDT, 2012).

Na década de 2010, grandes contratos de terceirização completa, como HP-Vale, no Brasil, e HP-GM, nos EUA (THIBODEAU, 2012), foram revistos para fazer com que os serviços de TI fossem novamente internalizados. 
O surgimento de aplicações em nuvem (GARTNER, 2013; DUFFY, 2008) faz com que áreas puramente usuárias de TI, como recursos humanos e marketing, passem a buscar diretamente no mercado soluções para suas necessidades de atendimento ao negócio. O sucesso de SalesForce.com (KONRAD, 2014) também é uma referência sobre a busca direta da área comercial e vendas por uma solução que não exige homologação técnica do departamento interno, não exige investimentos iniciais em infraestrutura de tecnologia nem atualizações periódicas de hardware: essas obrigações passam ao provedor de TI contratado. A área de TI, quando mantida a mentalidade histórica da criação e estabelecimento de uma solução própria, acaba sendo considerada uma barreira para a velocidade do negócio.

Muitos argumentos válidos são utilizados pelos gestores de TI, como segurança da informação. Discute-se o quanto é seguro deixar informações sensíveis ao negócio em nuvens públicas, como oferecidas por organizações como Amazon (AWS), Google ou Microsoft (Azure). Governos, como a União Europeia (TI INSIDE ONLINE, 2014), Alemanha (2009), País de Gales (WALES, 2014) e mais recentemente o Brasil, têm anunciado que para o armazenamento de dados dos cidadãos, os centros de dados devem necessariamente residir geograficamente no país. No Brasil primeiramente com a taxação de serviços de data centers no exterior (DREHER, 2014) e mais recentemente com o Marco Civil da Internet (BRASIL, 2014).

Porém se retorna ao equilíbrio necessário da equação entre desempenho e risco, para que o negócio possa continuar. Se tais riscos forem endereçados, torna-se uma questão de velocidade de evolução e disponibilização de ambientes e seu custo.

Portanto, a missão da área de TI e de seu gestor passa por esta transformação: de ser vista como um provedor de serviços de TI, mas também como um conselheiro confiável (trusted advisor, MAISTER; GREEN; GALFORD, 2000) na busca da melhor opção de sistemas de informação para as diferentes áreas da organização, de modo a otimizar custos e eficiência.

Weill e Ross (2004) apresentam arquétipos de acordo com como as responsabilidades pela tomada de decisão sobre tecnologia da informação estão distribuídas na organização:

- Monarquia dos negócios: um grupo de executivos de negócio ou executivos individuais;

- $\quad$ Monarquia de TI: indivíduos ou grupos de executivos de TI;

- $\quad$ Feudal: líderes das unidades de negócio ou donos de processos-chave; 
- $\quad$ Federada: executivos e grupos de negócio;

- Duopólio de TI: executivo de TI e mais um outro grupo (líderes de processo, ou executivo);

- $\quad$ Anarquia: cada usuário individual.

Com a crescente tendência na utilização de serviços de TI em nuvem (GARTNER, 2014) o locus de decisão não fica somente com o gestor de TI. O modelo anárquico começa a ganhar força, e com um poder cada vez mais concentrado diretamente nos gestores das áreas de negócio (IDC, 2014). Ao gestor de TI (CIO) cabe revisar seu papel para continuar contribuindo com o negócio (ALVES; RIEKSTIN, 2014; CERIONI; BUZO; SHIBATA, 2014; GARTNER, 2014; SIQUEIRA; SOUZA; VIANA, 2012).

\subsection{Governança de TI no Brasil}

O Brasil é um país emergente e tem um papel-chave no desenvolvimento da América Latina, tanto política quanto economicamente (OREIRO; PUNZO; ARAÚJO, 2012; THE ECONOMIST, 2009). Suas organizações são submetidas a regulações (GUERRA; FISCHMANN; MACHADO FILHO, 2009) e movimentos de internacionalização vêm crescendo nos últimos anos (FLEURY A.; FLEURY M.T.L., 2012; RHINOW, 2006).

As regulamentações da bolsa de valores melhoraram significativamente nos últimos dez anos, exigindo maior transparência em resultados e, para governança corporativa, planejamento, implantação e manutenção (GUERRA; FISCHMANN; MACHADO FILHO, 2009). As principais causas da demanda das empresas por estas práticas são as iniciativas de qualidade e processos iniciadas nos anos 1990 e regulações estabelecidas pela bolsa de valores BM\&F Bovespa (IBGC, 2009).

As organizações dependem da tecnologia da informação para manter suas operações e para gerar resultados a seus acionistas e à sociedade (LUFTMAN; BEM-ZVI, 2010). No Brasil, para empresas grandes e médias, 6\% de seu lucro líquido é investido em TI (MEIRELLES, 2012). Em bancos, o mínimo é de $10 \%$. 
Uma vez que os modelos padronizados de governança de TI aplicados em organizações brasileiras são, tipicamente, desenvolvidos no exterior, é necessário entender como se dá a adaptação a essa realidade diferente. Este contexto pode ser aplicado a outros mercados, tais como o asiático, outros países dos BRICS (CLARKE, 2007) ou outros países latino-americanos, que dado seu momento de crescimento, como o exemplo do Peru (IDC, 2014), necessitam de mais uso de padrões de mercado e internacionalização.

Em um trabalho de levantamento bibliométrico sobre governança de TI em organizações brasileiras (ALVES et al., 2013) foi realizada coleta de dados sobre fontes da literatura, através de buscas em publicações nas bases de dados SciElo, CAPES, SIBI/USP, AISel, Spell, Web of Science e Scopus, incluindo revisões de congressos brasileiros, como o Contecsi. A coleta foi conduzida de setembro a dezembro de 2012, encontrando 101 artigos publicados entre 2004 e 2011. No período se evidencia um aumento neste período de sete vezes, demonstrando o crescente interesse pelo assunto na literatura acadêmica brasileira. As palavras-chave utilizadas na busca foram: "governança de TI", "Tecnologia da Informação", "Cobit", "ITIL", "Governança", "alinhamento estratégico" e "IT governance". Estas palavras foram usadas individualmente e de modo combinado para aprimorar os resultados. Todos os artigos foram lidos em sua íntegra para verificar sua aderência aos modelos de Sambamurthy e Zmud (1999), Brown e Grant (2005) e Weill e Ross (2004) e pontuados de acordo com a utilização dos conceitos deste modelo. Os artigos foram relidos para garantir que a pontuação foi atribuída de maneira adequada.

As conclusões do levantamento bibliométrico foram:

- $\quad$ As publicações sobre governança de TI no Brasil aumentam ano a ano: demonstrando a importância do assunto no país.

- $\quad$ Amplo uso de casos de estudo para avaliação de governança de TI: apresentando o uso corporativo de conceitos de governança de TI, mas em sua maioria em empresas grandes. Poucos casos relacionados a pequenas e médias empresas: no Brasil estas empresas representam $70 \%$ da alocação da mão-de-obra formalizada (WORLD BANK DATABASE, 2007).

Referências a alinhamento entre negócio e TI: largamente presente, porém os resultados reais de aplicações práticas deste conceito e seus benefícios não foram avaliados.

- $\quad$ Referências aos modelos padronizados de governança de TI: apesar de encontradas nos artigos pesquisados, as estruturas de decisão nas organizações não são citadas. Apesar de ser 
um conceito fundamental para governança de TI, os artigos pesquisados não consideram este aspecto.

A partir destas conclusões, vê-se a necessidade de considerar o tamanho da organização no levantamento das informações e resultados na aplicação do modelo canônico de governança. Nota-se que o alinhamento de TI é bastante citado, porém não em detalhe da estrutura que permitiria uma análise mais profunda quanto ao desempenho.

Marques e Mota (2013) realizaram estudo bibliométrico similar, analisando 81 artigos publicados nos anais do Encontro Anual da Associação Nacional de Pós Graduação e Pesquisa em Administração (EnANPAD), no Encontro de Administração da Informação (EnADI) e no portal Scientific Periodicals Eletronic Library (SPELL) no período de 2007 a 2012. Neste estudo, a temática mais evidenciada foi o alinhamento estratégico aos negócios, mostrando a necessidade de entender a relação de TI com o desempenho. A menos evidenciada foi o gerenciamento de riscos relacionados à TI, mostrando um contraponto entre a origem e natureza do modelo canônico de governança de TI - focado em mitigação de riscos - e sua aplicação na realidade de organizações.

\subsection{Modelos padronizados de governança de TI}

Os modelos padronizados de governança de TI são fortemente apoiados em processos. Através deles são prescritas as atividades a serem cumpridas, os papéis a serem cumpridos, as responsabilidades e autorizações sobre as decisões de investimentos e de operação em TI.

Os modelos de processos que estabelecem sistemas de gestão da qualidade cresceram significativamente em número desde a década dos anos 1990, com o surgimento das normas da série ISO 9.000. Este conjunto de normas fornecia não somente modelos para sistemas de gerenciamento da qualidade, mas também modelos para aferição e auditoria da garantia da qualidade (BÉNÉZÉCH et al., 2001).

Os objetivos do gerenciamento por processos são: gerar entrega consistente dos serviços e conhecer como as ações afetam os negócios (DUFFY, 2008; MAXIMIANO, 2008). 
Pode-se verificar como ações afetam os negócios tendo uma visão do todo da organização. Processos têm a função de ajudar neste sentido. Um processo pode ser definido como uma série de ações conectadas, atividades e mudanças, executadas por agentes com a intenção de satisfazer ou atingir um objetivo.

O controle do processo pode, da mesma maneira, ser definido como planejamento e regulamentação, com o objetivo de executar o processo de uma maneira eficaz, aquele que pode ser repetido, e eficiente, aquele que é executado com o mínimo de esforço.

As práticas referenciadas em uma norma, depois documentadas formalmente pela organização, estabelecem a base de práticas canônicas (BROWN; DUGUID, 1991). Estas práticas são prescritas e estabelecem a maneira de controle da organização sobre as atividades dos profissionais, através de métricas e produtos - como documentos e relatórios - que são utilizados para fins de verificação de conformidade.

Uma norma, quando entendida como modelo canônico, define vocabulário, especificações técnicas e procedimentos gerenciais (COWAN; DAVID; FORAY, 2000). Ao adotar uma norma, esta passa a ser uma informação que deve ser eficaz ao se referir a conhecimentos explícitos e implícitos na organização, para que possa ser melhor aproveitada (BÉNÉZÉCH et al., 2001). A atividade de documentação dos processos é obrigatória para o processo de certificação, o que permite a comparação das organizações através dos estudos de caso.

A Tabela 7 resume os princípios de governança apresentados pelos modelos de referência analisados em maior detalhe neste trabalho.

Tabela 7 - Princípios propostos pelos modelos de referência de governança de TI.

\begin{tabular}{|c|c|}
\hline Modelo & Princípios \\
\hline ITIL v3 & $\begin{array}{l}\text { - } \quad \text { Ciclo de vida dos serviços: } \\
\text { - } \quad \text { Estratégia do serviço; } \\
\text { - } \quad \text { Desenho do serviço; } \\
\text { - } \quad \text { Transição do serviço; } \\
\text { - } \quad \text { Operação do serviço; }\end{array}$ \\
\hline
\end{tabular}




\begin{tabular}{|c|c|c|}
\hline & & - Melhoria contínua do serviço. \\
\hline Cobit 5 & - & $\begin{array}{l}\text { Cinco princípios de governança: } \\
\text { - } \quad \text { Atender às necessidades das partes envolvidas } \\
\text { (stakeholders); } \\
\text { - } \quad \text { Cobrir a organização fim-a-fim; } \\
\text { - } \quad \text { Aplicar um modelo único e integrado; } \\
\text { - } \quad \text { Permitir uma visão holística; } \\
\text { - } \quad \text { Separar governança de gerenciamento. }\end{array}$ \\
\hline ISO 20.000 & - & $\begin{array}{l}\text { Sistema de gestão de serviços baseado em melhoria } \\
\text { contínua (PDCA): } \\
\text { - } \quad \text { Desenho e transição de serviços novos ou modificados; } \\
\text { - } \quad \text { Processos para fornecimento do serviço; } \\
\text { - } \quad \text { Processos de relacionamento; } \\
\text { - } \quad \text { Processos de resolução; } \\
\text { - } \quad \text { Processos de controle. }\end{array}$ \\
\hline ISO 38.500 & - & $\begin{array}{l}\text { Responsabilidades (papéis e autoridades); } \\
\text { Estratégia (atual e futuro); } \\
\text { Aquisições; } \\
\text { Desempenho; } \\
\text { Conformidade; } \\
\text { Comportamento humano. }\end{array}$ \\
\hline
\end{tabular}

Modelos de referência cobrem diferentes necessidades de gerenciamento para as organizações, conforme apresentado na Figura 5. 


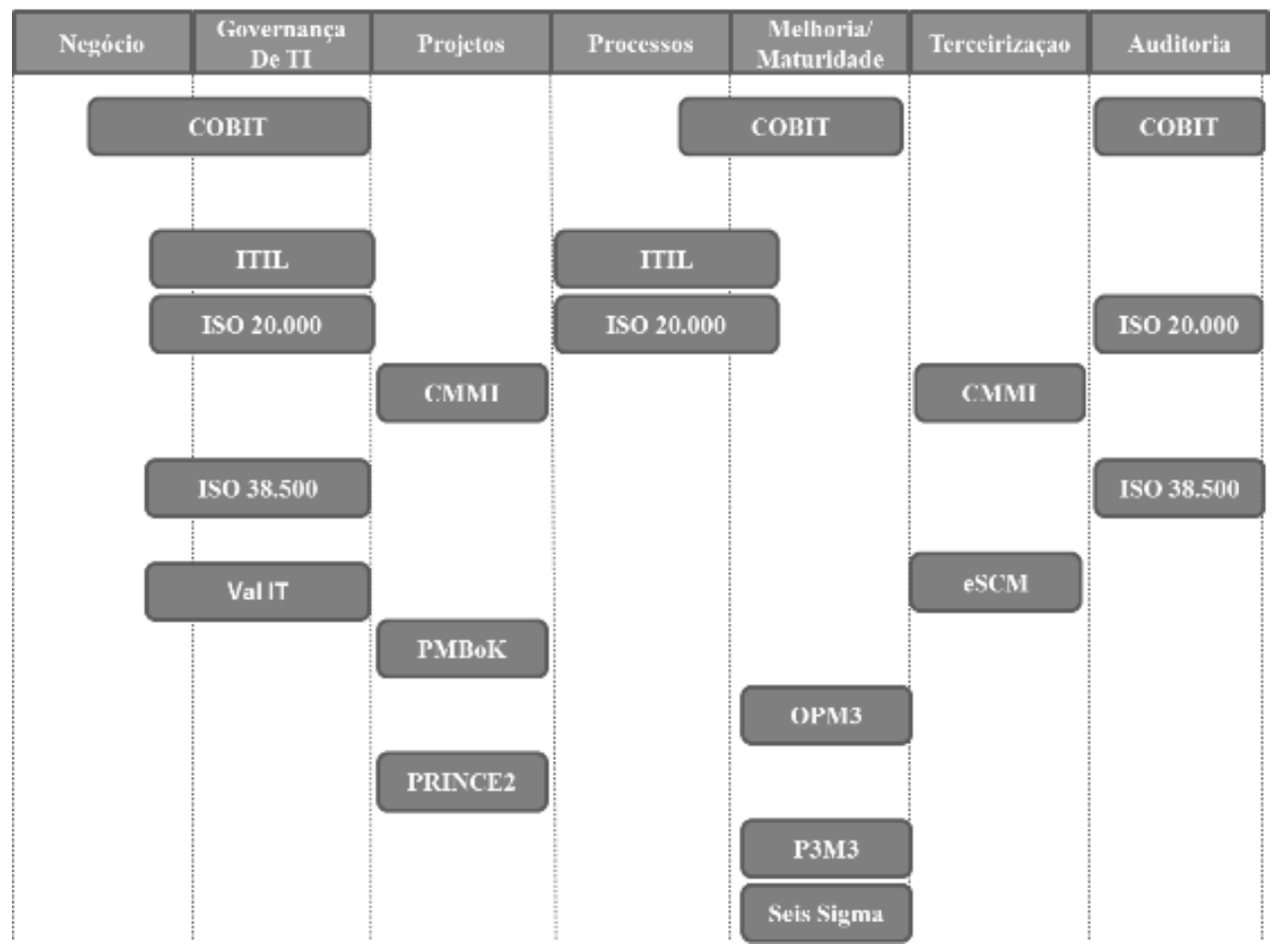

Figura 5 - Relacionamento entre modelos de referência e seu foco em processos na organização.

FONTE: Alves e Riekstin (2014).

No Brasil, nota-se que os diversos modelos são utilizados pelas organizações (ALVES et al., 2013). Porém, para efeitos práticos, as organizações adaptam os modelos para sua realidade, estabelecendo um modelo próprio de gerenciamento. Isto se dá pela necessidade de adaptação à realidade do momento dos negócios da organização prestadora de serviços de TI para adequação do equilíbrio entre risco e desempenho. A Figura 6 apresenta os resultados de uma pesquisa realizada com organizações brasileiras (MEIRELLES, 2012).

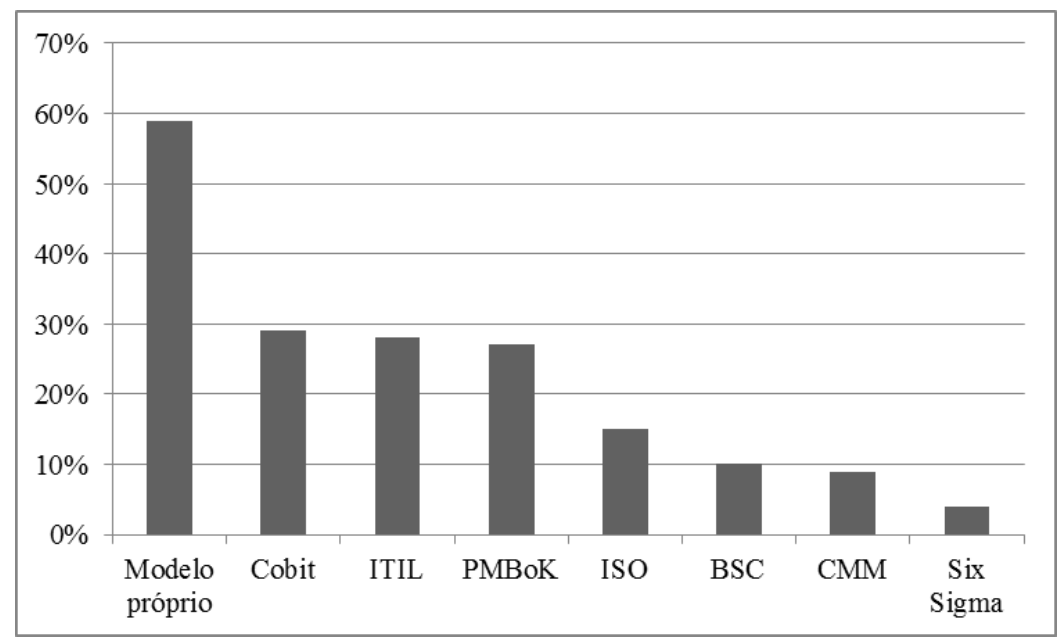

Figura 6 - Modelos de referência de governança de TI adotados por organizações brasileiras.

FONTE: adaptado de Meirelles, 2012. 
Fenômeno similar pode ser observado em outras regiões do mundo, como Europa (GUSTAFSSON et al., 2001; RUZEVICIUS; ADOMAITIENE; SIRVIDAITE, 2004), Ásia e Oceania (ABU-MUSA, 2008; ALI, 2006; LEE; PALMER, 1999; SAMSOM; TERZIOVSKI, 1999; TERZIOVSKI; POWER; SOHAL, 2003); Estados Unidos e Canadá (BART; TERUEL, 2010; LO et al., 2013).

Em particular nas organizações cujo negócio-fim é tecnologia da informação, a utilização de modelos padronizados de governança de TI visa o aumento de consistência operacional, através da diminuição de erros vindas da consolidação e prescrição de práticas.

A norma ISO 20.000 apresenta uma referência através da qual há requisitos mínimos comuns a serem cumpridos pelas organizações que a utilizam. Pela natureza do processo de certificação, em que há auditorias externas por um órgão independente, as organizações que querem contratar a prestação de serviços de TI contam com um referencial mais confiável, com regras claras e abertas. Antes de sua publicação, o mercado procurava por certificações e treinamentos individuais dos profissionais em ITIL e Cobit por exemplo. Porém isto demonstrava o conhecimento das pessoas, e não a consolidação de práticas na organização como em um modelo certificado de gerenciamento por processos. Esta certificação, neste mercado, pode ser considerada um diferencial já que dentro do universo de prestadores de serviços de TI, (CEBRASSE, 2014; APM GROUP, 2013; STANDARD ORGANIZATION, 2013).

O PMBoK (Project Management Book of Knowledge) foi bastante citado, porém não recebeu foco nesta pesquisa por não tratar de serviços continuados com os clientes como nos abordados pelo modelo canônico escolhido, já que projeto é definido como "um empreendimento temporário com o objetivo de criar um produto ou serviço único" (PMI BRASIL, 2014).

\subsection{ITIL}

ITIL (Information Technology Infrastructure Library) foi publicado inicialmente no final dos anos 1980 pela CCTA (Central Computing and Telecommunications Agency), agora OGC 
(Office of Government Commerce), órgão do governo do Reino Unido (TAYLOR et al., 2007). Exames de certificação para profissionais foram disponibilizados a partir de 1991.

Seu principal objetivo foi padronizar entregas de serviços de tecnologia da informação de diferentes fornecedores do mercado privado a instituições governamentais. A versão que se tornou mais amplamente conhecida e difundida internacionalmente foi a segunda, publicada em junho de 2001 (TAYLOR et al., 2007).

A versão 3 liberada em julho de 2007 ampliou o modelo para uma visão maior sobre a organização, incluindo: processos relacionados a outras áreas da organização como gerenciamento do conhecimento, marketing e administração; métrica de maturidade de processos, muito similar às de Cobit e CMMI (Capability Maturity Model Integrated); visão da organização como um todo. Os processos são divididos em cinco grupos que representam o ciclo de negócios de TI, partindo da definição da estratégia dos serviços, seu desenho, a transição para a operação, a operação e as práticas de melhoria contínua. A Tabela 8 apresenta um resumo deste conceito, bem como os processos que pertencem a cada grupo.

Tabela 8 - Processos de governança de TI segundo ITIL v3.

\begin{tabular}{|c|c|c|}
\hline Grupo & Foco & Processos \\
\hline $\begin{array}{l}\text { Estratégia } \\
\text { do serviço }\end{array}$ & $\begin{array}{l}\text { Identificação de } \\
\text { oportunidades de } \\
\text { mercado. }\end{array}$ & $\begin{array}{ll}\text { - } & \text { Gerenciamento do portfólio de } \\
& \text { Serviços; } \\
\text { - } & \text { Geração da Estratégia; } \\
\text { - } & \text { Gerenciamento da Demanda; } \\
\text { - } & \text { Gerenciamento Financeiro em TI. }\end{array}$ \\
\hline $\begin{array}{l}\text { Desenho } \\
\text { do serviço }\end{array}$ & $\begin{array}{l}\text { Atividades para } \\
\text { desenvolver a estratégia } \\
\text { no desenho dos serviços } \\
\text { propostos. }\end{array}$ & $\begin{array}{l}\text { - Gerenciamento de Catálogo de } \\
\text { - } \text { Serviços; } \\
\text { - } \quad \text { Gerenciamento de Níveis de Serviço; } \\
\text { - } \quad \text { Gerenciamento da Capacidade; } \\
\text { - } \quad \text { Gerenciamento de Continuidade de } \\
\quad \text { Serviços de TI; } \\
\text { - } \quad \text { Gerenciamento de Segurança da } \\
\text { Informação; } \\
\text { - Gerenciamento de Fornecedores. }\end{array}$ \\
\hline
\end{tabular}




\begin{tabular}{|c|c|c|}
\hline $\begin{array}{l}\text { Transição } \\
\text { do serviço }\end{array}$ & $\begin{array}{l}\text { Implantação do desenho } \\
\text { do serviço. }\end{array}$ & $\begin{array}{ll}\text { - } & \text { Suporte e Planejamento da } \\
& \text { Transição; } \\
\text { - } & \text { Gerenciamento de Configuração e } \\
& \text { Ativos de Serviço; } \\
\text { - } & \text { Gerenciamento de Liberações e } \\
& \text { Distribuição; } \\
\text { - } & \text { Gerenciamento de Mudanças; } \\
\text { - } & \text { Validação e Testes do serviço; } \\
\text { - } & \text { Avaliação; } \\
\text { - } & \text { Gerenciamento de Conhecimento. }\end{array}$ \\
\hline $\begin{array}{l}\text { Operação } \\
\text { do serviço }\end{array}$ & $\begin{array}{l}\text { Atividades requeridas } \\
\text { para operar os serviços e } \\
\text { manter suas } \\
\text { funcionalidades } \\
\text { conforme definidas nos } \\
\text { acordos de níveis de } \\
\text { serviço. }\end{array}$ & $\begin{array}{ll}\text { - } & \text { Gerenciamento de Eventos; } \\
\text { - } & \text { Gerenciamento de Incidentes; } \\
\text { - } & \text { Execução de Requisição; } \\
\text { - } & \text { Gerenciamento de Problemas; } \\
\text { - } & \text { Gerenciamento de Acesso. }\end{array}$ \\
\hline $\begin{array}{l}\text { Melhoria } \\
\text { contínua }\end{array}$ & $\begin{array}{l}\text { Capacidade de entregar } \\
\text { melhoria contínua e } \\
\text { qualidade dos serviços } \\
\text { prestados. }\end{array}$ & $\begin{array}{ll}\text { - } & \text { Relatório do serviço; } \\
\text { - } & \text { Medição do serviço. }\end{array}$ \\
\hline
\end{tabular}

FONTE: Taylor et al., 2007.

A estratégia e a organização da empresa determinam os comportamentos desejáveis que motivam a governança corporativa. A organização de TI e comportamentos desejáveis, por sua vez, colocam em prática a estratégia e a organização da empresa. Os arranjos de governança de TI são concebidos como meio de habilitar e influenciar a estratégia e os direitos decisórios são atribuídos para as decisões-chave que governam cada ativo. Os mecanismos de governança de TI devem estar em harmonia com as estruturas organizacionais de TI. Um exemplo de mecanismo é ITIL. As “metas de desempenho do negócio" determinam a eficácia esperada das estratégias da companhia e permitem avaliar o sucesso dos esforços de governança. As métricas e responsabilidades de TI definem a contribuição de TI para as metas de desempenho da empresa e permitem avaliar a eficácia de TI de maneira separada (CLEMENTI; CARVALHO, 2006). 


\subsection{Cobit}

Cobit (Control Objectives for Information Technology) foi inicialmente publicado em 1996. Sua origem é ISACA (2012), que havia sido formado em 1967, por um grupo de profissionais que trabalhavam com controles de auditoria de sistemas de informação.

Criado inicialmente como um guia para auditorias, pela comunidade de conformidade (assurance), o modelo foi sendo aperfeiçoado ao longo do tempo para contemplar práticas de controle (versão 2 de 1998), gerenciamento (versão 3 de 2000) e governança (versão 4 de 2005).

Seu principal objetivo era ser um modelo abrangente e aplicável para a auditoria e controle dos processos de TI, desde o planejamento da tecnologia até a monitoração e auditoria de todos os processos ao:

- $\quad$ Estabelecer relacionamentos com os requisitos do negócio;

- $\quad$ Organizar as atividades de TI em um modelo de processo genérico;

- Identificar os principais recursos de TI, nos quais deve haver mais investimento;

- $\quad$ Definir os objetivos de controle que devem ser considerados para a gestão.

A versão 5 lançada em 2013 apresenta uma visão holística sobre a organização, buscando identificar e interligar fatores de negócio à tecnologia da informação de maneira iterativa. Estabelece sete categorias que permitem a governança de TI:

- $\quad$ Princípios, políticas e modelos: veículos para traduzir o comportamento desejado em guias práticos para o gerenciamento do dia-a-dia;

- Processos: descrevem um conjunto organizado de práticas e atividades para atingir determinados objetivos e produzir uma série de saídas que suportem o atingimento dos objetivos gerais de TI;

- Estruturas organizacionais: chave para os processos de tomada de decisão na organização;

- Cultura, ética e comportamento: de indivíduos e da organização, que normalmente são subestimados como fator de sucesso em atividades de governança e gerenciamento; 
- Informação: requerida para manter a organização funcionando e bem governada. Operacionalmente, informação é um produto-chave para a empresa.

- $\quad$ Serviços, infraestrutura e aplicação: incluem infraestrutura, tecnologia e aplicações que fornecem processamento e serviços de tecnologia da informação para a organização;

- $\quad$ Pessoas, habilidades e competências: requeridas para completar com sucesso todas as atividades, bem como tomar as melhores decisões e conduzir ações corretivas.

A visão Cobit sobre a integração da governança de TI, seus processos e como esta vai da estratégia à operação em um modelo iterativo, em que cada camada contribui com a criação de valor ao negócio é representada na Figura 7 e na Figura 8.

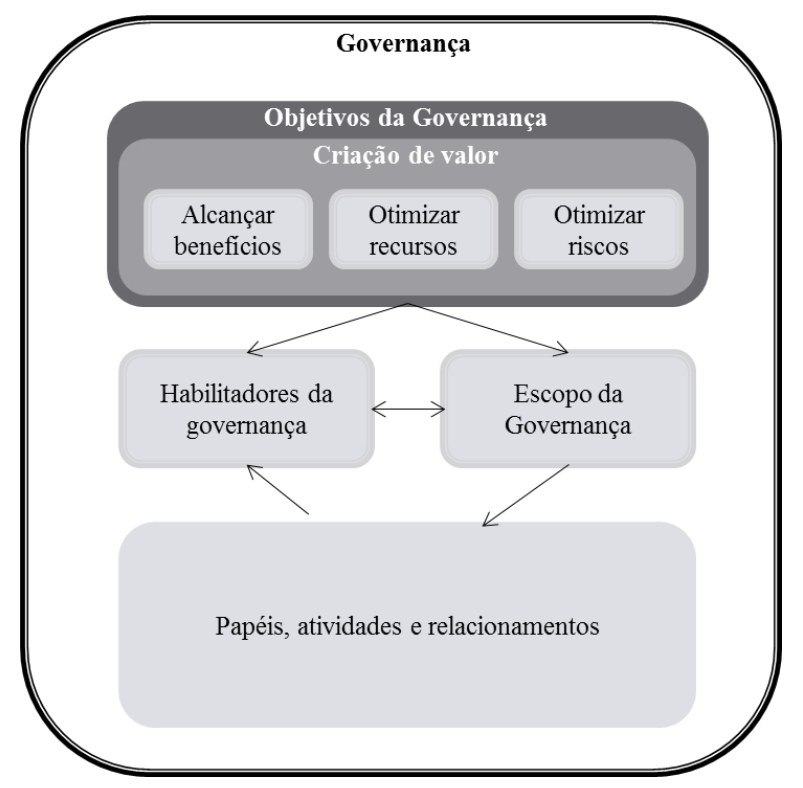

Figura 7 - Modelo de criação de valor a partir da governança de TI FONTE: adaptado de ISACA, 2012. 


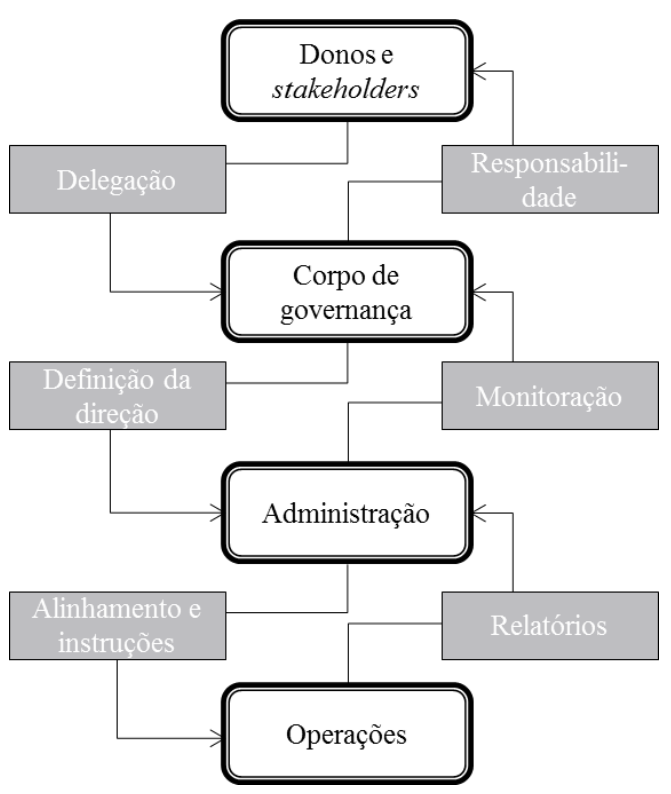

Figura 8 - Processo iterativo que desdobra a estratégia organizacional nas atividades operacionais de TI.

FONTE: adaptado de ISACA, 2012.

Os processos definidos pelo Cobit são apresentados na Tabela 9.

Tabela 9 - Processos segundo Cobit 5.

\begin{tabular}{|c|c|c|}
\hline & Código & Processo \\
\hline \multirow{5}{*}{$\begin{array}{l}\text { Avaliar, } \\
\text { direcionar e } \\
\text { monitorar }\end{array}$} & EDM1 & Definir e manter a plataforma de governança \\
\hline & EDM2 & Garantir a otimização do valor \\
\hline & EDM3 & Garantir a otimização de risco \\
\hline & EDM4 & Garantir a otimização de recurso \\
\hline & EDM5 & Garantir transparência ao investidor \\
\hline \multirow{12}{*}{$\begin{array}{l}\text { Alinhar, } \\
\text { planejar e } \\
\text { organizar }\end{array}$} & APO1 & Definir a plataforma de gerenciamento para TI \\
\hline & APO2 & Definir estratégia \\
\hline & APO3 & Gerenciar arquitetura corporativa \\
\hline & APO4 & Gerenciar inovação \\
\hline & APO5 & Gerenciar portfólio \\
\hline & APO6 & Gerenciar orçamento e custo \\
\hline & APO7 & Gerenciar recursos humanos \\
\hline & APO8 & Gerenciar relações \\
\hline & APO9 & Gerenciar acordos de serviços \\
\hline & APO10 & Gerenciar fornecedores \\
\hline & APO11 & Gerenciar qualidade \\
\hline & APO12 & Gerenciar risco \\
\hline \multirow{5}{*}{$\begin{array}{l}\text { Construir, } \\
\text { adquirir e } \\
\text { implantar }\end{array}$} & BAI1 & Gerenciar programas e projetos \\
\hline & BAI2 & Definir requisitos \\
\hline & BAI3 & Identificar e construir soluções \\
\hline & BAI4 & Gerenciar disponibilidade e capacidade \\
\hline & BAI5 & Habilitar mudança organizacional \\
\hline
\end{tabular}




\begin{tabular}{|l|l|l|}
\hline \multirow{4}{*}{$\begin{array}{l}\text { Entregar, } \\
\text { serviços } \\
\text { suporte }\end{array}$} & BAI6 & Gerenciar mudança \\
\cline { 2 - 3 } & BAI7 & Aceite e transição da mudança \\
\cline { 2 - 3 } & BAI8 & Gerenciamento de conhecimento \\
\cline { 2 - 3 } & DSS1 & Gerenciar operações \\
\cline { 2 - 3 } & DSS2 & Gerenciar ativos \\
\cline { 2 - 3 } & DSS3 & Gerenciar configuração \\
\cline { 2 - 3 } & DSS4 & Gerenciar solicitações de serviço e incidentes \\
\cline { 2 - 3 } & DSS5 & Gerenciar problemas \\
\cline { 2 - 3 } & DSS6 & Gerenciar continuidade \\
\cline { 2 - 3 } & DSS7 & Gerenciar segurança \\
\cline { 2 - 3 } $\begin{array}{l}\text { Monitorar, } \\
\text { avaliar } \\
\text { levantar }\end{array}$ & DSS8 & Gerenciar controles de processos de negócio \\
\cline { 2 - 3 } & MEA1 & Monitorar e avaliar desempenho e conformidade \\
\cline { 2 - 3 } & MEA2 & Monitorar sistema de controle interno \\
\cline { 2 - 3 } & MEA3 & Monitorar e avaliar conformidade com requisitos externos \\
\hline
\end{tabular}

FONTE: ISACA, 2012.

Das quatro categorias de objetivos de TI: corporativo, cliente, interno e aprendizado e crescimento, aplicam-se os três últimos, uma vez que os objetivos de TI para empresas prestadoras de serviços de TI são os mesmos de negócio.

Para os processos estabelecidos no Cobit, são associados níveis de maturidade de execução dos mesmos pela organização para atingir os objetivos relacionados à TI, apresentados na Tabela 10. O nível máximo se dá quando o processo apresenta práticas de melhoria contínua e mínimo quando não é formalizado. Estes níveis ajudam na análise para encontrar o nível de maturidade atual do processo da organização.

Tabela 10 - Níveis de maturidade segundo Cobit 5.

\begin{tabular}{|c|c|c|}
\hline $\begin{array}{l}\text { Níveis de maturidade } \\
\text { e capacidade }\end{array}$ & Descrição & Contexto \\
\hline 5 - Otimizado & $\begin{array}{l}\text { Melhorado continuamente para atender } \\
\text { objetivos corporativos atuais e projetados. }\end{array}$ & \multirow[t]{3}{*}{ Visão da empresa } \\
\hline 4 - Previsível & $\begin{array}{l}\text { Opera dentro de limites definidos para atingir } \\
\text { os objetivos do processo. }\end{array}$ & \\
\hline 3 - Estabelecido & $\begin{array}{l}\text { Implementado, usando um processo definido } \\
\text { que é capaz de atingir seus objetivos. }\end{array}$ & \\
\hline $2-$ Gerenciado & $\begin{array}{l}\text { Implementado e gerenciado: planejamento, } \\
\text { monitoração e ajustes. Seus produtos são }\end{array}$ & Visão individual \\
\hline
\end{tabular}




\begin{tabular}{|l|l|}
\hline 1 - Executado & $\begin{array}{l}\text { estabelecidos, controlados e mantidos } \\
\text { adequadamente. }\end{array}$ \\
\hline 0 - Incompleto & $\begin{array}{l}\text { Não está implementado, ou há pouca ou } \\
\text { nenhuma evidência de qualquer resultado } \\
\text { advindo do processo. }\end{array}$ \\
\hline
\end{tabular}

FONTE: ISACA, 2012.

\subsection{Combinação ITIL e Cobit}

ISACA (Information Systems Audit and Control Association) é um instituto cuja missão é ser a fonte confiável de conhecimento, padrões, relacionamento e desenvolvimento de carreira para auditores de sistemas de informação, segurança, risco, privacidade e profissionais de governança (ISACA, 2012). Sua origem, como citado anteriormente, vem dos processos de auditoria de práticas nas organizações.

ISACA publica regularmente documentos comparativos entre Cobit e outros modelos de referência para auxiliar no entendimento da integração e também valorizar suas publicações e corpo de conhecimento.

A partir do surgimento do ITGI em 1998, este instituo e ISACA notaram que os modelos de referência existentes não deveriam ser tratados como excludentes: era preciso criar análises e comparações para auxiliar na tomada de decisões dos gestores de TI.

Em 2007, ISACA publicou um documento estabelecendo o paralelo entre Cobit 4.0 e ITIL v2 (ITGI, 2007). O resultado desta comparação é reproduzido na Figura 9.

\begin{tabular}{|c|c|c|c|c|c|c|c|c|c|c|c|c|c|}
\hline COBIT 4: domínios de processos & $\mathbf{1}$ & $\mathbf{2}$ & $\mathbf{3}$ & $\mathbf{4}$ & $\mathbf{5}$ & $\mathbf{6}$ & $\mathbf{7}$ & $\mathbf{8}$ & $\mathbf{9}$ & $\mathbf{1 0}$ & $\mathbf{1 1}$ & $\mathbf{1 2}$ & $\mathbf{1 3}$ \\
\hline Planejar e Organizar & - & - & - & - & $\mathrm{O}$ & - & - & - & - & - & $\mathrm{X}$ & $\mathrm{X}$ & $\mathrm{X}$ \\
\hline Adquirir e Implantar & - & - & - & - & - & + & & $\mathrm{X}$ & $\mathrm{X}$ & $\mathrm{X}$ & $\mathrm{X}$ & $\mathrm{X}$ & $\mathrm{X}$ \\
\hline Entregar e Manter & + & $\mathrm{O}$ & + & + & - & + & - & + & + & + & - & - & - \\
\hline Monitorar e Avaliar & - & - & - & - & $\mathrm{X}$ & $\mathrm{X}$ & $\mathrm{X}$ & $\mathrm{X}$ & $\mathrm{X}$ & $\mathrm{X}$ & $\mathrm{X}$ & $\mathrm{X}$ & $\mathrm{X}$ \\
\hline \multicolumn{1}{|c|}{} \\
\hline
\end{tabular}


(+) Relação significativa (mais de 30 requisitos mapeados em processos Cobit)

(O) Relação menor (entre 15 e 29 requisitos de informação mapeados)

(-) Relação sem foco (menos de 15 requisitos mapeados)

(X) Não há processo Cobit.

Figura 9 - Comparação entre Cobit 4 e ITIL v2 feita por ISACA. FONTE: ITGI, 2007.

Segundo ISACA (2012), os processos ITIL “obviamente têm boa representação nos domínios Cobit". Porém, é possível fazer uma análise ao se estabelecer pontuações para as relações, de acordo com os critérios utilizados na avaliação, usando escala proposta em método por Fishbein e Ajzen (2010):

$$
\begin{array}{ll}
- & (+)=3 ; \\
- & (\mathrm{O})=2 ; \\
- & (-)=1 ; \\
- & (\mathrm{X})=0 .
\end{array}
$$

Ao se fazer a média ponderada do número de vezes em que cada resultado aparece o valor é 1,0. Para ser considerada uma relação obviamente consistente, este valor deveria ser muito maior que 1,0 (Fishbein e Ajzen, 2010). Há vantagens qualitativas desta combinação:

- $\quad$ Unificação de modelo de governança de TI, ao mostrar a ligação de cada processo em detalhe;

- $\quad$ Entendimento em conjunto dos benefícios propostos por cada um: COBIT com modelo de maturidade e integração da governança e ITIL com os processos operacionais de TI;

- Compreensão do ciclo de vida dos serviços de TI para a organização, iniciando pelas necessidades de negócio e passando pela governança de TI, projetos, processos, e melhoria contínua (Figura 8).

Apesar do objetivo deste mapeamento ser aproximar os modelos, facilitando o entendimento e interações por quem pretende utilizá-los (ITGI, 2007), este introduz uma outra desvantagem: o aumento da complexidade dos conceitos. Algo tratado de maneira superficial por ambas as publicações é sua aplicabilidade de acordo com o tamanho da organização. Os modelos apenas citam que a implantação e a escolha dos processos, bem como seu grau de maturidade a ser perseguido, devem ser feitas de acordo com as necessidades e realidade da organização. 
Empresas pequenas poderiam se beneficiar de um corpo de conhecimento de melhores práticas publicadas por organizações maiores e com maior experiência. Porém os modelos se tornam tão complexos que se afastam das prioridades das empresas ou, ainda pior, acabam gerando grandes custos na tentativa de sua implantação.

De maneira repetitiva, a combinação entre os modelos introduz outra opção de referência a ser utilizada pelas organizações, agravando o problema discutido na introdução deste trabalho (Seção 1.5): o aumento do número de modelos de referência e sua complexidade.

\subsection{ISO 38.500}

A norma ISO 38.500 foi lançada em 2008 (ABNT, 2009) e traduzida como norma ABNT em 2009. Seu objetivo é proporcionar um quadro de princípios, avaliando, direcionando e monitorando a utilização das tecnologias nas organizações. Sua estrutura define um sistema de governança corporativa para a TI. A norma está baseada em seis princípios: responsabilidades, estratégia, aquisições, desempenho e conformidade. Em termos de certificações formais não houve grande procura por parte das organizações.

Esta norma define os objetivos de governança de TI como:

- $\quad$ Garantir que os investimentos de TI gerem real valor (desempenho);

- $\quad$ Gerenciar riscos de TI.

Não trata especificamente de processos de governança ou gerenciamento de TI, uma vez que se apoia sobre a ISO 20.000 para isto. Seu enfoque é sobre dimensões que impactam diretamente nos objetivos citados acima:

- Responsabilidade: definição de autorizações e papéis em diferentes pontos da organização sobre os investimentos de TI;

- $\quad$ Estratégia: alinhamento com as necessidades de negócio; 
- $\quad$ Aquisição: práticas para aquisição de produtos e serviços de tecnologia da informação utilizados como insumos nas atividades da organização;

- $\quad$ Desempenho: medição constante sobre indicadores de TI e do negócio;

- Conformidade: foco em auditoria e atenção às práticas prescritas;

- Comportamento humano: como os profissionais que trabalham na organização são impactados e como devem atuar para garantir desempenho e controle de riscos.

\subsection{ISO 20.000}

O conjunto de normas ISO 20.000 foi originalmente publicado em 2008 (ABNT, 2011). Tendo como base a norma inglesa BS 15.000 (ABNT, 2011), tornou-se um padrão mundial para gerenciamento de serviços de TI. Da mesma forma que o ITIL, que havia nascido no Reino Unido, a norma surgiu para regulamentar de maneira formalizada, através de auditorias externas, os prestadores de serviços de TI especialmente para o governo.

O conjunto de normas em 2005 foi publicado em duas partes: a primeira com os requisitos de certificação (ISO 20.000:2008-1) e a segunda (ISO 20.000:2008-2) com recomendações de boas práticas. Esta é mais extensa, mas como não é obrigatória para a certificação acaba sendo menos seguida pelas organizações (DISTERER, 2009). Sua tradução para o português e reconhecimento pela ABNT no Brasil se deu em fevereiro de 2008.

Em 2011 a norma sofreu uma revisão (ISO 20.000:2011). Uma terceira parte foi adicionada na forma de relatório técnico, com direcionamento para a definição de escopo e aplicabilidade da norma para as organizações. Seu objetivo era esclarecer quais organizações e como aplicar os requisitos de certificação. Esta necessidade surgiu da discussão que havia na diferença entre organizações que utilizavam a tecnologia da informação como meio para obter seus resultados, em contraposição a organizações cujo negócio-fim era a TI.

Esta revisão, para organizações prestadoras de serviços de TI cobre justamente o problema enfrentado pela ISO 38.500 em termos de adoção: como esta é muito genérica acaba tendo poucos atrativos práticos, como benefícios ou vantagens de curto prazo, em sua implantação e manutenção. 
A norma é baseada em princípios de melhoria contínua. A Figura 10 apresenta o ciclo PDCA aplicado à gestão de serviços conforme apresentado na norma ISO 20.000 (ABNT, 2011). Esta definição permite melhor integração com outros conjuntos de normas, como ISO 9.001 (qualidade) e ISO 27.001 (segurança da informação).

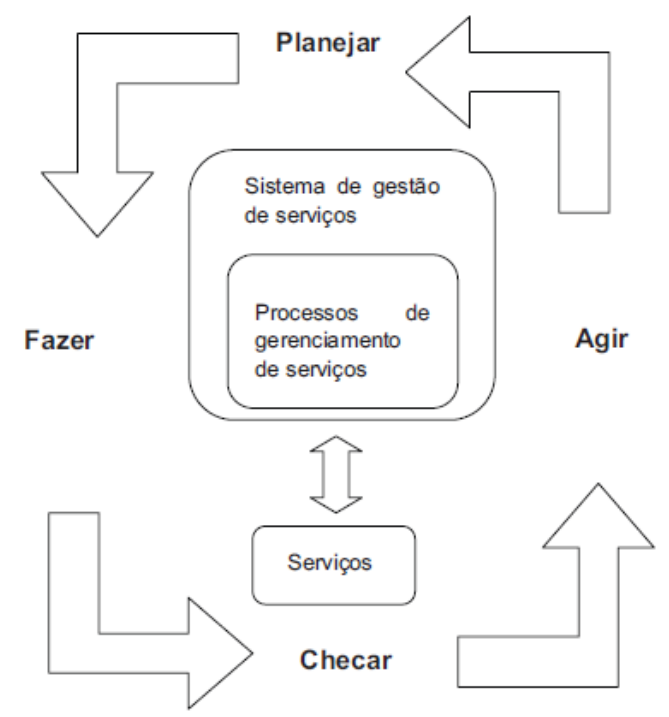

Figura 10 - Método PDCA aplicado ao serviço de gestão. FONTE: ABNT, 2011.

Sua principal motivação é deixar claro que a gestão de serviços não é algo pontual, não sendo apenas caracterizada por seu projeto de implantação. Trata-se de uma mudança constante na organização, que demanda aperfeiçoamento contínuo de suas práticas.

\subsection{Modelo canônico de processos de gerenciamento de serviços de TI}

Um modelo canônico deve ser uma base que permita uma comparação direta e clara (HSING; SOUZA, 2013). Por haver organizações certificadas no Brasil e tratar do gerenciamento de serviços de TI é possível estabelecer uma comparação entre seu modelo padronizado de processo de governança de TI e os casos reais apresentados nas organizações, com um referencial firmemente estabelecido. 
Em relação aos modelos apresentados anteriormente nesta seção, a predominância é de modelos para prescrição de práticas da alta administração para os profissionais, muitas vezes nascidos de correntes de auditorias. O foco é controle, voltado à estabilização de atividades, para obtenção de desempenho controlado e gerenciamento de riscos.

Apesar da norma ISO 38.500 ser especificamente voltada à governança de TI, ainda não há organizações certificadas no Brasil. Por se tratar de uma norma genérica, para qualquer tipo e tamanho de organização, acaba tendo poucos atrativos práticos, como benefícios ou vantagens de curto prazo, em sua implantação e manutenção.

Duas das vantagens apontadas pela norma ISO 20.000 (ABNT, 2011) para as organizações que a seguem, e posteriormente buscam uma certificação, são:

- $\quad$ Aumento do controle sobre processos, diminuindo assim seus riscos operacionais de TI; - $\quad$ Aumento do desempenho organizacional.

Para identificar os requisitos de certificação de uma norma, é necessário buscar os itens marcados como “deve". Estes são as obrigações que uma organização deve comprovar através de evidências em auditoria, para se mostrar em conformidade com os requisitos e poder pleitear a certificação.

Sobre sua estrutura, a norma ISO 20.000 é dividida em cláusulas. As três primeiras estabelecem a norma ao apresentar introdução ao tema de gerenciamento de serviços e um glossário. A cláusula 4 da norma define o ciclo de melhoria contínua baseado no PDCA. Todos os processos e práticas definidos na norma devem seguir este ciclo, de tal modo que contenham etapas de planejamento, execução, medições e tomada de ações corretivas. Como o enfoque desta pesquisa se dá nos processos de gerenciamento de serviços de TI, esta ênfase é dada aos itens subsequentes.

O Apêndice 4 apresenta em detalhes os requisitos para certificação na norma ISO 20.000. As demais partes da norma (dois e três) são referências de boas práticas, trazendo informações sobre sua interpretação e como organizações a utilizam, porém não refletem obrigatoriedade de conformidade para auditoria. 
Outros trabalhos pesquisados propõem a utilização de modelos canônicos de referência para a estabelecer a relação entre desempenho e risco. Nestes casos, o modelo utilizado foi a ISO 9.001, como Singh (2008). Tal comparação com esta pesquisa é válida porque são ambos referenciais normativos, certificáveis, sendo que organizações que as adotam passam por auditorias externas.

Em diferentes países, buscando a similaridade da adoção da norma ISO 9.001 em organizações daquelas localidades, como Lituânia (RUZEVICIUS; ADOMAITIENE; SIRVIDAITE, 2004), Hong Kong (LEE; PALMER, 1999), Austrália e Nova Zelândia (TERZIOVSKI; POWER; SOHAL, 1996), Estados Unidos (LO et al., 2013) e Suécia (GUSTAFSSON et al., 2001).

Sobre a realidade no Brasil, Alves et al. (2013), Marques e Mota (2013), Rigoni; Dwivedi e Hoppen (2010), Moraes (2007) realizaram estudo sobre a aplicação de modelos padronizados de governança de TI em organizações brasileiras.

Uma vez que os requisitos da norma ISO 20.000 devem ser atendidos para o sucesso da certificação, parte-se do princípio, ao analisar somente organizações certificadas, que este prérequisito foi atendido. Introduz-se na coleta e análise de dados a medição do nível de maturidade proposto por Cobit (ISACA, 2012) e ITIL (TAYLOR et al., 2007) para avaliar o quão aderente estão os processos aos modelos padronizados de governança de TI. Desta forma é possível fazer uma análise mais aprofundada de como as organizações certificadas em ISO 20.000 aplicam os modelos em sua prática.

O modelo de Singh (2008) é usado como referência para este estudo, ao elencar fatores que podem ser extraídos de um modelo padronizado de governança de TI para formarem o construto de análise do desempenho organizacional. Nesta pesquisa se usa esta referência, como paralelo para a norma ISO 20.000 .

Os fatores críticos de sucesso compilados por autores como Bulchand-Gidumal e MeliánGonzález (2011), de Haes e van Grembergen (2010), Nfuka e Rusu (2011) e Sasaki (2001) são usados para análise das principais expectativas, problemas e benefícios obtidos pela organização ao fazer uso de modelos padronizados de governança de TI. A Tabela 11 resume estes fatores: 
Tabela 11 - Fatores críticos de sucesso para utilização de modelos padronizados de governança de TI.

\begin{tabular}{|l|l|}
\hline Fator crítico de sucesso & Referência \\
\hline Ajuda externa (consultores, professores) & de Haes e van Grembergen (2010); Singh (2008) \\
\hline Comprometimento da alta administração & Nfuka e Rusu (2011) \\
\hline $\begin{array}{l}\text { Definição de métricas do processo ou da } \\
\text { gestão }\end{array}$ & de Haes e van Grembergen (2010); Sasaki (2001) \\
\hline Documentação & Singh (2008) \\
\hline $\begin{array}{l}\text { Educação / mudança da cultura dos } \\
\text { funcionários }\end{array}$ & Nfuka e Rusu (2011); Sasaki (2001) \\
\hline Educação e treinamento & Nfuka e Rusu (2011); Singh (2008) \\
\hline Foco nos clientes & $\begin{array}{l}\text { Bulchand-Gidumal e Melián-González (2011); de } \\
\text { Haes e van Grambergen (2010); Singh (2008) }\end{array}$ \\
\hline Fornecedores confiáveis & $\begin{array}{l}\text { Bulchand-Gidumal e Melián-González (2011); } \\
\text { Singh (2008) }\end{array}$ \\
\hline $\begin{array}{l}\text { Planejamento para implementar os } \\
\text { processos }\end{array}$ & $\begin{array}{l}\text { Bulchand-Gidumal e Melián-González (2011); } \\
\text { Singh (2008) }\end{array}$ \\
\hline Planos e ações & $\begin{array}{l}\text { Bulchand-Gidumal e Melián-González (2011); de } \\
\text { Haes e van Grambergen (2010); Nfuka e Rusu } \\
\text { (2011); Singh (2008) }\end{array}$ \\
\hline Políticas de gerenciamento & Singh (2008) \\
\hline Processo estável & de Haes e van Grambergen (2010); Singh (2008) \\
\hline Profissionais competentes & Singh (2008) \\
\hline Respeito pelo funcionário & Sasaki (2001) \\
\hline Sistema de comunicação eficaz & $\begin{array}{l}\text { Bulchand-Gidumal e Melián-González (2011); } \\
\text { Nfuka e Rusu (2011); Singh (2008) }\end{array}$ \\
\hline & \\
\hline
\end{tabular}




\section{MÉTODO DE PESQUISA}

Este capítulo apresenta o método utilizado para a condução desta pesquisa. Com base na principal questão de pesquisa deste trabalho foi preciso detalhar os conceitos sobre governança de TI, riscos e desempenho. Estes foram especificados de acordo com as dimensões desempenho e riscos, conforme apresentado nas Seções 2.1 e 2.2.

Além dos conceitos eram necessários modelos de referência de processos de governança de TI. A norma ISO 20.000 foi utilizada como modelo canônico de governança de TI (seção 3.10), sendo contexto comum a todas as organizações pesquisadas. O uso de um modelo canônico garante uma base de comparação mínima com base nos requisitos da norma.

\subsection{Tipo e metodologia de pesquisa}

A pesquisa empírica realizada é de natureza qualitativa, conduzida através do método de estudos de casos múltiplos.

Strauss e Corbin (1990) afirmam que pesquisas qualitativas são utilizadas para se descobrir e entender sobre fenômenos sobre os quais ainda se conhece pouco ou se obter novos pontos de vista sobre algo que já se conhece bastante. Segundo Godoy (1995), a pesquisa qualitativa parte de focos ou questões de interesse amplo que vão se definindo no decorrer da execução da pesquisa.

A natureza exploratória e qualitativa da pesquisa empírica proposta é justificável, porque os serviços de TI crescem no mercado brasileiro, ano após ano, em taxas muito maiores que o crescimento econômico do país (IDC, 2013). Como a norma ISO 20.000 apresenta requisitos específicos para este setor, pesquisar suas implicações passa a ser relevante.

Para a condução do trabalho foi utilizado o método proposto por Webster e Watson (2002), conforme apresentado na Figura 11. 


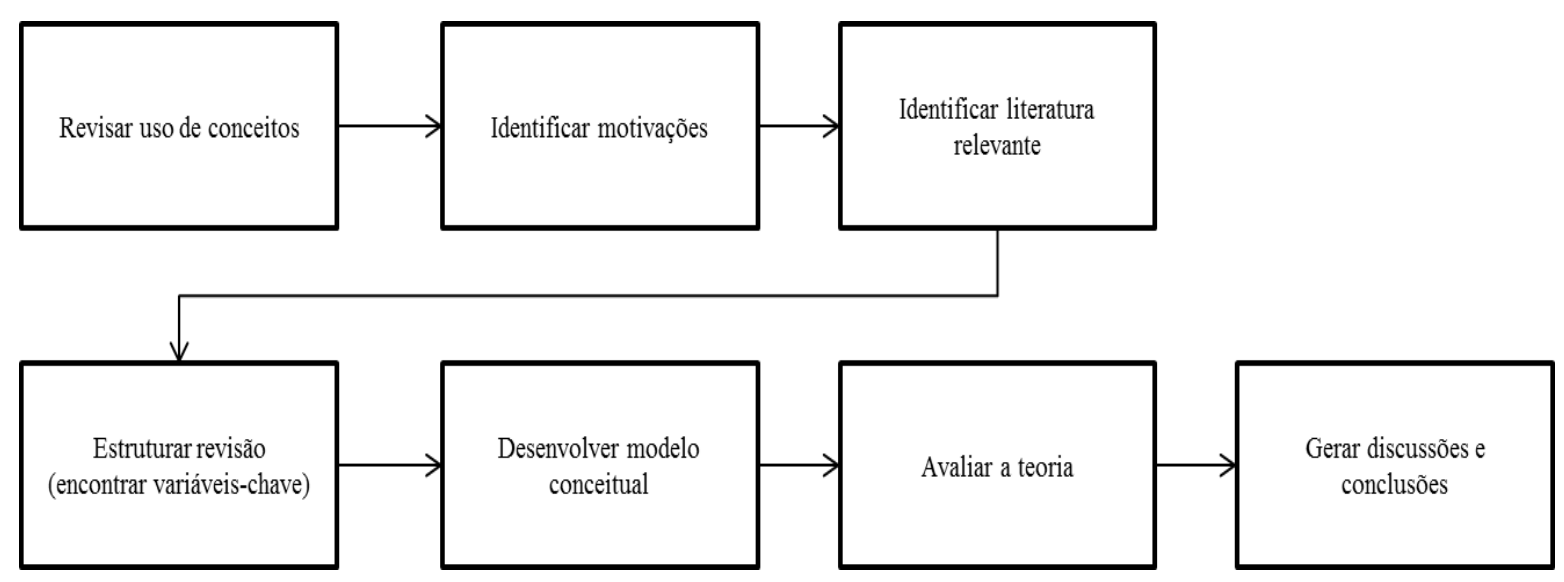

Figura 11 - Método de referência para a pesquisa.

FONTE: adaptado de Webster e Watson, 2002.

Durante a revisão de literatura foram feitas comparações entre os modelos de referência encontrados, apresentadas no Capítulo 3, para que se pudessem estabelecer os construtos específicos a se utilizar nesta análise, conforme a etapa de estruturação da revisão.

Um dos desafios era comparar um modelo canônico prescrito aos exemplos práticos encontrados na realidade das organizações. A norma ISO 20.000 foi escolhida como modelo canônico, uma vez que é um referencial em que as organizações podem se certificar passando por um processo formal de auditoria externa. Neste caso, o conjunto de requisitos mínimos, com controlada dose de subjetividade, deve ser seguido pelas diferentes organizações (CHAN; REICH, 2007; DEUTSCHER; FELDEN, 2009;).

$\mathrm{Na}$ etapa de desenvolvimento do modelo conceitual, o estudo realizado por Brown e Diguid (1991) foi utilizado por apresentar uma maneira de comparação entre a base canônica e as atividades observadas na prática da organização. Na literatura foram encontrados trabalhos que utilizavam o conjunto de normas ISO 9.000 para estudos e comparações com casos reais. O estudo feito por Singh (2008) estabelece construtos com base nos princípios de gerenciamento da qualidade estabelecidos pela norma. Esta análise pode ser aplicada à ISO 20.000, uma vez que se trata de uma base canônica para sistema de gerenciamento por processos.

Para a avaliação da teoria eram necessárias a coleta e a análise de dados práticos nas organizações, em comparação com o modelo canônico. Os instrumentos de coleta foram desenvolvidos tomando por referência estudos comparativos similares, voltados à norma ISO 9.001 (SAMSON; TERZIOVSKI, 1999) e à governança de TI (DE HAES; VAN 
GREMBERGEN, 2010; PRASAD; HEALES; GREEN, 2010). A coleta de dados foi dividida em duas fases subsequentes, cada qual utilizando ferramentas de coleta de dados diferentes, visando objetivos específicos.

A fase 1 teve por objetivo realizar levantamento horizontal entre as organizações certificadas ISO 20.000 no Brasil, identificando em particular os processos considerados mais críticos na operação dos negócios de tecnologia da informação. Este levantamento foi feito através de questionário, respondido por profissionais da alta direção da organização, buscando informações sobre: razões da busca pela certificação, e quais dos processos de governança de TI são os mais críticos para os negócios.

A fase 2 se propôs a comparar o modelo canônico, a norma ISO 20.000, com implantações reais, buscando detalhamento no modo como os processos foram aplicados na prática. A coleta de dados foi feita através de entrevistas em organizações deste universo. O foco principal foi sobre os processos de governança de TI que constam na norma padronizada, uma vez que, por serem certificadas, devem seguir o mesmo conjunto. Desse modo foi possível buscar um aprofundamento sobre como foram tratados os processos dos modelos de referência com base no que a organização já possuía e como se deram as mudanças na aplicação prática. Estas verificações são feitas através do efeito percebido da mudança, coletado nas entrevistas. Foram usados métodos para redução do viés sobre as respostas, uma vez que se avalia a conformidade com relação a uma referência normativa, as pessoas podem tender a dar respostas consideradas certas ou aceitáveis, ao invés de verdadeiras (FISHBEIN; AJZEN, 2010).

Esta combinação se deu para que as entrevistas realizadas nos estudos de caso fossem tratadas com maior nível de detalhe com relação a alguns processos. Assim, a partir das respostas aos questionários, aplicou-se um filtro sobre a norma para tratar com maior nível de detalhe durante as entrevistas nas organizações. A partir das respostas aos questionários, são utilizados apenas os processos considerados mais relevantes, conforme apresentados no Capítulo 3.

O questionário da primeira fase foi disponibilizado através de website, sendo realizada de março a agosto de 2014. Para a segunda fase da coleta de dados, as entrevistas não foram gravadas, conforme recomendação de Walsham apud Saccol (2005). O pesquisador tomou notas detalhadas da conversação já em meio eletrônico, auxiliado por um tablet. A segunda fase foi 
realizada de maio a setembro de 2014, com sobreposição à primeira fase, ajustando-se à disponibilidade de agenda dos participantes.

Como as respostas provêm dos profissionais respondentes ou entrevistados, utilizou-se o método proposto por Fishbein e Ajzen (2010) para reduzir vieses associados às respostas. Conforme já mencionado, tais vieses podem ocorrer uma vez que o entrevistado pode tender a dar a resposta "considerada correta", já que se preocupa com a imagem da organização em que trabalha e representa, ao invés de se concentrar no que de fato aconteceu.

Para evitar estas armadilhas, foram propostas no questionário perguntas cujas respostas se anulam na análise de sua pontuação em escala Likert (SINGH, 2008). Com base na experiência do pesquisador, utilizando recomendações a auditores (ISACA, 2012; ABNT, 2002), são aprofundados pontos muito próximos dos modelos prescritos na base canônica.

Para a análise dos dados utilizou-se o método proposto por Brown e Duguid (1991), de modo a comparar o modelo canônico - norma ISO 20.000 - com os processos encontrados na prática das organizações estudadas. Para a avaliação dos dados dos questionários, usou-se o modelo de avaliação descrito por Luftman e Ben-Zvi (2010) e Luftman (2000).

\subsection{Delineamento da pesquisa e escolha dos casos}

Yin (2009) define que para melhorar a qualidade de estudos de caso é preciso cumprir quatro condições, descritas e consideradas nesta pesquisa conforma apresentado na Tabela 12.

- Validade do construto: identificar as medições operacionais corretas para os conceitos sendo estudados;

- Validade interna: buscar estabelecer uma relação causal, dentro de certas condições (não se aplica pela natureza exploratória desta pesquisa, segundo YIN, 2009);

- Validade externa: definir o domínio em que as evidências do estudo podem ser generalizadas;

- Confiabilidade: demonstrar que a operação do estudo pode ser repetida, com resultados similares. 
Tabela 12 - Condições de qualidade em estudos de caso, aplicadas a esta pesquisa.

\begin{tabular}{|c|c|c|}
\hline $\begin{array}{l}\text { Condição de } \\
\text { qualidade }\end{array}$ & $\begin{array}{l}\text { Tática do estudo de } \\
\text { casos }\end{array}$ & Aplicação nesta pesquisa \\
\hline \multirow[t]{3}{*}{$\begin{array}{l}\text { Validade do } \\
\text { construto }\end{array}$} & $\begin{array}{l}\text { Usar múltiplas fontes } \\
\text { de evidência. }\end{array}$ & $\begin{array}{l}\text { - Questionário; } \\
\text { - Entrevista; } \\
\text { - Website; } \\
\text { - Intranet. }\end{array}$ \\
\hline & $\begin{array}{l}\text { Estabelecer a cadeia } \\
\text { de evidências. }\end{array}$ & $\begin{array}{l}\text { - Questionário (primeira fase); } \\
\text { - } \quad \text { Estrutura de questões (segunda fase); } \\
\text { - } \text { Referências bibliográficas para sustentar as } \\
\text { questões e respostas possíveis; } \\
\text { - Apresentação no relato dos casos as perguntas } \\
\text { a que se referem; } \\
\text { - Análise e conclusões baseadas e relacionadas } \\
\text { diretamente às questões propostas nas duas fases. }\end{array}$ \\
\hline & $\begin{array}{l}\text { Ter informantes que } \\
\text { possam revisar o } \\
\text { rascunho do estudo } \\
\text { de caso. }\end{array}$ & - Aplicado no caso piloto. \\
\hline Validade externa & $\begin{array}{l}\text { Usar lógica da } \\
\text { replicação (em } \\
\text { estudos de caso } \\
\text { múltiplos). }\end{array}$ & $\begin{array}{l}\text { - Estudo de oito casos, em que se podia: } \\
\text { - } \text { Prever resultados similares (como } \\
\text { a importância relativa de alguns } \\
\text { processos) e } \\
\text { - } \text { Prever resultados contrastantes } \\
\text { (como a importância relativa de } \\
\text { alguns processos), mas por razões } \\
\text { antecipadamente conhecidas } \\
\text { (como o tamanho da organização). } \\
\text { - Entender as condições em que os fenômenos } \\
\text { podem: } \\
\text { - } \text { Ocorrer tipicamente: organizações } \\
\text { prestadoras de serviços de TI; }\end{array}$ \\
\hline
\end{tabular}




\begin{tabular}{|c|c|c|}
\hline & & $\begin{array}{l}\text { - Não ocorreriam tipicamente: } \\
\text { organizações consumidoras de } \\
\text { serviços de TI. }\end{array}$ \\
\hline \multirow[t]{2}{*}{ Confiabilidade } & $\begin{array}{l}\text { Usar protocolo de } \\
\text { estudo de caso. }\end{array}$ & $\begin{array}{l}\text { - Criação dos questionários (primeira fase); } \\
\text { - Estruturação das perguntas e respostas } \\
\text { possíveis para entrevistas (segunda fase). }\end{array}$ \\
\hline & $\begin{array}{l}\text { Desenvolver base de } \\
\text { dados de estudo de } \\
\text { caso. }\end{array}$ & $\begin{array}{l}\text { - Referências bibliográficas para sustentar as } \\
\text { questões e respostas possíveis; } \\
\text { - Apresentação de análise de cada questão da } \\
\text { primeira fase. } \\
\text { - Apresentação no relato dos casos as perguntas } \\
\text { a que se referem. }\end{array}$ \\
\hline
\end{tabular}

FONTE: adaptado de YIN, 2009.

Segundo Yin (2009) as pesquisas empíricas devem ter um delineamento para indicar qual o caminho a ser seguido desde as questões propostas até as respostas desejadas. O autor define cinco itens a serem apresentados, detalhados nas subseções seguintes:

- $\quad$ Questões da pesquisa (apresentada na Seção 1.3);

- Proposições;

- Definição da unidade de análise;

- Descrição da lógica ligando os dados obtidos às proposições;

- Definição de critérios para interpretar as descobertas da pesquisa.

\subsubsection{Proposições}

Yin (2009) afirma que pesquisas exploratórias buscam novas ideias e hipóteses para a explicação de fenômenos. Mesmo assim precisam partir de referenciais teóricos para que possam chegar a algum objetivo determinado, iniciando a exploração com lógica e direção, mesmo que mais tarde as propostas iniciais sejam comprovadas equivocadas. O método de Watson e Webster (2002) utilizado nesta pesquisa propõe algo nessa direção. Alguma flexibilidade deve ser preservada ao construir as proposições do estudo, para que outros aspectos do fenômeno observado possam ser considerados (SELLTIZ et al., 1965). 
O levantamento bibliográfico apontou quais os modelos de referência em governança de TI, e como se poderia analisar quanto são aplicados na prática nas organizações conforme prescritos, em forma de fatores que apontem essas diferenças.

Foi preciso escolher um modelo canônico de governança de TI para ser aplicado como referência comum aos estudos de caso, permitindo a comparação estruturada entre as informações coletadas.

As proposições do estudo, derivadas do modelo de risco e desempenho (Capítulo 2), de interesse do administrador da organização, regulado pela governança de TI (Capítulo 3), aplicando o modelo canônico (Seção 3.10) são as seguintes:

- $\quad$ Sistemas de governança de TI em organizações prestadoras de serviços de tecnologia da informação apresentam diferenças na maneira em que os processos prescritos no modelo canônico são aplicados;

- $\quad$ O equacionamento entre risco e desempenho de organizações prestadoras de serviços de TI pode ser regulado pelos processos de governança de TI.

\subsubsection{Unidade de análise e escolha dos casos}

Foi escolhido o modelo de estudos de casos múltiplos porque se trata do método mais apropriado ao examinar eventos contemporâneos, segundo Yin (2009), pois inclui a observação direta dos eventos sendo estudados - neste caso as implicações da governança de TI sobre a organização - e entrevistas com as pessoas envolvidas nos mesmos. O estudo de caso único não se aplicava nesta pesquisa uma vez que não trata de caso extremo. Estudos de casos múltiplos são considerados mais robustos e convincentes que estudos de caso único (HERRIOTT; FIRESTONE, 1983).

Neste trabalho é usado o estudo de casos múltiplos, permitindo a comparação de graus de implantação e utilização dos processos de governança de TI entre organizações diferentes, porém com referencial comum: a certificação pelo modelo canônico escolhido, de acordo com 
o método apresentado por Godoy (1995). Pode-se considerar o uso de múltiplos casos como a aplicação de múltiplos experimentos, pela lógica da replicação (YIN, 2009).

Foram identificadas as organizações brasileiras certificadas ISO 20.000, conforme lista reconhecida mundialmente (APM GROUP, 2013). Estas 27 organizações estão listadas na Tabela 13, conforme consulta realizada até dezembro/2013; foram filtradas e agrupadas organizações pertencentes ao mesmo grupo, sendo apenas razões sociais distintas.

Em complemento foram contatados alguns dos organismos certificadores para validar se havia mais empresas que pudessem ter seus nomes identificados. Através de livro de autor nacional sobre o modelo canônico de governança de TI, foram obtidos mais nomes de organizações certificadas e foi possível obter seus contatos para esta pesquisa (SOULA, 2013). Os próprios profissionais de algumas organizações se dispuseram a ajudar ao fornecer os contatos de outras em empresas também certificadas, uma vez que se conhecem por encontros em treinamentos ou fóruns de discussão sobre a norma.

Tabela 13 - Organizações brasileiras certificadas ISO 20.000.

\begin{tabular}{|c|c|c|c|}
\hline № & Organização & Fonte & $\begin{array}{l}\text { Organismo } \\
\text { certificador }\end{array}$ \\
\hline 1 & Algar & Soula, 2013 & BSI \\
\hline 2 & Amdocs Inc. & APM Group, 2013 & Intertek India Pvt \\
\hline 3 & Asyst & Soula, 2013 & BSI \\
\hline 4 & Atena Tecnologia Ltda. & APM Group, 2013 & \begin{tabular}{|ll} 
Bureau & Veritas \\
Certification & H. SAS
\end{tabular} \\
\hline 5 & Atento Brasil S/A & APM Group, 2013 & \begin{tabular}{|l} 
Fundação Carlos \\
Alberto Vanzolini
\end{tabular} \\
\hline 6 & Ativas & Soula, 2013 & BSI \\
\hline 7 & Avansys Tecnologia Ltda & APM Group, 2013 & \begin{tabular}{|ll} 
Bureau & Veritas \\
Certification & H. SAS \\
\end{tabular} \\
\hline 8 & Banco Bradesco S.A & APM Group, 2013 & $\begin{array}{l}\text { Fundação Carlos } \\
\text { Alberto Vanzolini }\end{array}$ \\
\hline 9 & Banco do Brasil & Soula, 2013 & BSI \\
\hline 10 & Bradesco Seguros e Previdência & APM Group, 2013 & $\begin{array}{l}\text { Fundação Carlos } \\
\text { Alberto Vanzolini }\end{array}$ \\
\hline 11 & Call Tecnologia E Serviços Ltda & APM Group, 2013 & BSI \\
\hline 12 & $\begin{array}{l}\text { CASSI - Caixa de Assistência dos } \\
\text { Funcionários do Banco do Brasil }\end{array}$ & APM Group, 2013 & BSI \\
\hline 13 & $\begin{array}{l}\text { Companhia de Processamento de dados } \\
\text { do Estado de São Paulo - PRODESP }\end{array}$ & APM Group, 2013 & $\begin{array}{l}\text { Fundação Carlos } \\
\text { Alberto Vanzolini }\end{array}$ \\
\hline
\end{tabular}




\begin{tabular}{|c|c|c|c|}
\hline 14 & CPM Braxis S/A (atualmente Capgemini) & $\begin{array}{l}\text { APM Group, 2013; } \\
\text { Soula, } 2013\end{array}$ & $\begin{array}{ll}\text { Bureau } & \text { Veritas } \\
\text { Certification H. SAS }\end{array}$ \\
\hline 15 & $\mathrm{HP}$ & Soula, 2013 & SAI Global \\
\hline 16 & Interadapt Solutions S.A. & APM Group, 2013 & \begin{tabular}{|l|l} 
Bureau & Veritas \\
Certification & H. SAS \\
\end{tabular} \\
\hline 17 & Netservice & Soula, 2013 & BSI \\
\hline 18 & Netsol & Soula, 2013 & BSI \\
\hline 19 & Nexa Tecnologia & Soula, 2013 & BSI \\
\hline 20 & Orange Business Services Brazil & APM Group, 2013 & AFNOR Certification \\
\hline 21 & $\begin{array}{l}\text { Perfil Informática Comércio } \\
\text { Manutenção Ltda. (Digisystem) }\end{array}$ & APM Group, 2013 & Fund. C.A. Vanzolini \\
\hline 22 & $\begin{array}{l}\text { PromonLogicalis Tecnologia e } \\
\text { Participações Ltda. (PTLS Serviços de } \\
\text { Tecnologia e Assessoria Técnica Ltda.) }\end{array}$ & Group, 2013 & $\mathrm{ABS}$ \\
\hline 23 & $\begin{array}{l}\text { Sysdesign Consultoria em Informática } \\
\text { Ltda. }\end{array}$ & APM Group, 2013 & $\begin{array}{ll}\text { Bureau } & \text { Veritas } \\
\text { Certification } & \text { H. SAS }\end{array}$ \\
\hline 24 & TecnoComp Tecnologia e Serviços Ltda & APM Group, 2013 & Fund. C.A. Vanzolini \\
\hline 25 & $\begin{array}{l}\text { TIVIT Terceirização de Processos, } \\
\text { Serviços e Tecnologia S/A }\end{array}$ & APM Group, 2013 & DQS GmbH \\
\hline 26 & Unisys & Soula, 2013 & DQS GmbH \\
\hline 27 & ZCR Informática Ltda. & APM Group, 2013 & $\begin{array}{ll}\text { Bureau } & \text { Veritas } \\
\text { Certification H. SAS }\end{array}$ \\
\hline
\end{tabular}

A maioria destas empresas são prestadoras de serviços de TI, com exceção das de número 8, 9, 10 e 12. Estas são instituições financeiras ou áreas de apoio deste tipo de empresa. Como visto na Seção 1.1, os investimentos neste ramo de negócio são significativos, portanto o interesse das instituições financeiras por modelos e certificações em governança de TI segue a mesma direção de empresas com este fim, o que nos leva a considerar também estas empresas como parte do universo pesquisado.

Esta pesquisa tem como foco as organizações certificadas ISO 20.000 que tenham tecnologia da informação como seu negócio-fim: empresas cujos processos empregados visam lucro através de serviços prestados na área de tecnologia da informação. Estas atividades podem incluir desenvolvimento de software, desenvolvimento de hardware, integração de sistemas e terceirização (PRADO; CRISTOFOLI; SCHMIDT, 2012; AUBERT; PATRY; RIVARD, 2005). Os questionários de qualificação e o convite para a participação da segunda fase de entrevistas foram enviados a todas as organizações listadas na Tabela 13. 
Cada uma das empresas convidadas a participar da pesquisa recebeu uma carta impressa e um e-mail personalizados contendo informações sobre o trabalho e a senha para acesso ao questionário.

Para a qualificação das organizações foram utilizadas características citadas na literatura sobre modelos padronizados de governança de TI, como relevantes para a avaliação da adoção de práticas, usando como base o modelo utilizado por Bart e Teruel (2010), apresentados na Tabela 14.

Tabela 14 - Fatores de qualificação das organizações pesquisadas.

\begin{tabular}{|c|c|c|}
\hline Característica & Descrição & Referência \\
\hline Certificação ISO 20.000 & $\begin{array}{l}\text { Característica } \\
\text { compartilhada por todas as } \\
\text { empresas participantes. }\end{array}$ & $\begin{array}{l}\text { ISO } 20.000 \text { certifications (APM } \\
\text { Group, 2013). }\end{array}$ \\
\hline Contexto do país & $\begin{array}{l}\text { Momento econômico e } \\
\text { político que atravessa o país } \\
\text { que possam interferir em } \\
\text { seu desempenho. } \\
\text { Característica } \\
\text { compartilhada por todas as } \\
\text { empresas participantes: } \\
\text { Brasil. }\end{array}$ & $\begin{array}{l}\text { Hofstede (2012); Melville; } \\
\text { Kraemer e Gurbaxani (2004). }\end{array}$ \\
\hline $\begin{array}{l}\text { Estrutura organizacional / } \\
\text { complexidade }\end{array}$ & $\begin{array}{l}\text { Como se estabelece o locus } \\
\text { de decisão sobre TI da } \\
\text { organização. }\end{array}$ & $\begin{array}{l}\text { Sambamurthy e Zmud (1999); } \\
\text { Singh (2008); Siqueira; Souza e } \\
\text { Viana (2012). }\end{array}$ \\
\hline Tamanho da organização & $\begin{array}{l}\text { Número de profissionais da } \\
\text { organização. }\end{array}$ & $\begin{array}{l}\text { Bulchand-Gidumal e Melián- } \\
\text { González (2011); } \\
\text { Singh (2008). }\end{array}$ \\
\hline Investimentos em TI & $\begin{array}{llll}\text { Como são } & \text { decididos } & \text { e } \\
\text { direcionados } & & & \text { os } \\
\text { investimentos } & \text { em } & \text { TI } & \text { da } \\
\text { organização. } & & & \end{array}$ & $\begin{array}{l}\text { Bulchand-Gidumal e Melián- } \\
\text { González (2011); Xue; Liang e } \\
\text { Boulton (2008); Zwicker et al. } \\
\text { (2007). }\end{array}$ \\
\hline
\end{tabular}




\subsubsection{Lógica ligando os dados obtidos às proposições}

A análise dos dados é apresentada pelos resultados consolidados dos questionários da primeira fase, permitindo a comparação entre as respostas das organizações participantes e relatórios. Sobre as entrevistas, são apresentados relatórios individuais de cada respondente contendo os principais pontos levantados, seguindo a estruturação das perguntas realizadas. Segundo Eisenhardt (1988), as descrições dos casos são centrais para a geração de ideias, como etapa proposta na Figura 11. A autora também defende que "o processo permite que as características únicas de cada caso surjam antes do investigador partir para a identificação de padrões de generalização entre os casos".

O questionário utilizado para a primeira fase encontra-se no Apêndice 2, contendo as perguntas disponibilizadas através de website SurveyMonkey (2014). As questões foram definidas de acordo com os referenciais teóricos pesquisados (YIN, 2009). Sua composição evita vieses de respostas inconsistentes dadas pelo entrevistado (FISHBEIN; AJZEN, 2010).

As questões foram agrupadas em fatores de acordo com as referências bibliográficas utilizadas no estudo de referencial teórico:

- Qualificadoras: dados sobre as organizações que permitam categorizá-las, como por exemplo número de profissionais e investimentos em certificações.

- $\quad$ Priorização dos processos: quais os processos considerados mais importantes do modelo canônico de governança de TI.

- $\quad$ Motivadores: principais para adoção e manutenção da certificação ISO 20.000.

- $\quad$ Risco: atitude da organização perante riscos, bem como fatores internos e externos à organização que permitem encontrar a definição de risco para a empresa.

- Desempenho: benefícios e melhorias trazidos aos serviços de TI e ao negócio.

- $\quad$ Fatores críticos de sucesso: para adoção e manutenção da certificação ISO 20.000.

- Dificuldades: para manutenção dos processos.

- Profissional: questões de como as práticas prescritas pela organização, processos e requisitos necessários do modelo canônico de governança de TI impactam os profissionais. 
Para a apresentação dos casos, utilizou-se o modelo analítico-linear apresentado por Yin (2009). Os relatos foram organizados segundo a forma proposta no roteiro de estruturação da entrevista. As perguntas foram divididas como:

- Qualificadoras: para verificar como a organização se enquadra no delineamento de pesquisa, validando respostas obtidas na primeira fase da coleta de dados (BART; TUREL, 2010).

- $\quad$ Risco: com base nas referências, foram elaboradas perguntas semiabertas que permitem identificar posturas da organização ante riscos (conforme Tabela 15). As questões foram divididas entre contexto interno ou externo à organização, conforme apresentado na Seção 2.1, e buscam informações sobre os fatores de risco descritos na Tabela 3.

- Desempenho: com base nas referências, foram elaboradas perguntas semiabertas que permitem identificar a maneira como o desempenho é compreendido pelas mesmas (conforme Tabela 16). As questões foram divididas entre contexto interno ou externo à organização, conforme apresentado na Seção 2.2, buscando informações sobre os fatores de desempenho descritos na Tabela 4.

Tabela 15 - Roteiro de entrevistas com questões sobre risco.

\begin{tabular}{|c|c|c|}
\hline Número & Questão & Referência \\
\hline R1 & $\begin{array}{l}\text { Como é o processo de decisão sobre } \\
\text { investimentos em TI? } \\
\text { - departamental; } \\
\text { - interdepartamental; } \\
\text { - corporativo; } \\
\text { - interorganizacional. }\end{array}$ & Xue; Liang e Boulton (2008) \\
\hline $\mathrm{R} 2$ & $\begin{array}{l}\text { Quais fatores externos à organização você } \\
\text { acredita que têm maior impacto sobre os } \\
\text { investimentos em TI? } \\
\text { - pressões competitivas; } \\
\text { - pressões institucionais/regulamentações; } \\
\text { - recursos externos; } \\
\text { - transferência de riscos; } \\
\text { - ameaças e ataques. }\end{array}$ & $\begin{array}{l}\text { de Haes e Van Grembergen } \\
\text { (2010); Hughes (2006); Lunardi } \\
\text { (2008); Wilkin e Chenhall } \\
\text { (2010); Xue; Liang e Boulton } \\
\text { (2008) }\end{array}$ \\
\hline
\end{tabular}




\begin{tabular}{|c|c|c|}
\hline Número & Questão & Referência \\
\hline R3 & $\begin{array}{l}\text { Quais fatores externos à organização você } \\
\text { acredita que têm maior impacto sobre a } \\
\text { segurança da informação? } \\
\text { - roubo; } \\
\text { - ataques e ameaças; } \\
\text { - falsificação; } \\
\text { - fatores naturais; } \\
\text { - regulamentações externas. }\end{array}$ & $\begin{array}{l}\text { Alves e Cherobim (2004); } \\
\text { ISACA (2012); } \\
\text { Van Grembergen e de Haes } \\
\text { (2000); Hughes (2006); Lunardi } \\
\text { (2008); Wilkin e Chenhall (2010) }\end{array}$ \\
\hline $\mathrm{R} 4$ & $\begin{array}{l}\text { Quais medidas são adotadas para } \\
\text { continuidade dos negócios? } \\
\text { - nada; } \\
\text { - plano de recuperação de desastre; } \\
\text { - site de contingência a frio; } \\
\text { - site de contingência a quente. }\end{array}$ & $\begin{array}{l}\text { ISACA (2012); Taylor et al. } \\
(2007)\end{array}$ \\
\hline $\mathrm{R} 5$ & $\begin{array}{l}\text { Quais fatores internos à organização você } \\
\text { acredita que têm maior impacto sobre a } \\
\text { segurança da informação? } \\
\text { - omissão intencional; } \\
\text { - roubo por empregados; } \\
\text { - fraude; } \\
\text { - erros; } \\
\text { - desempenho indevido; } \\
\text { - indisponibilidade da informação; } \\
\text { - erro na integridade da informação; } \\
\text { - falta/incorretos níveis de confidencialidade } \\
\text { da informação. }\end{array}$ & $\begin{array}{l}\text { Alves e Cherobim (2004); } \\
\text { Bulchand-Gidumal e Melián- } \\
\text { González (2011) }\end{array}$ \\
\hline
\end{tabular}




\begin{tabular}{|c|c|c|}
\hline Número & Questão & Referência \\
\hline R6 & $\begin{array}{l}\text { Quais das características de riscos de TI } \\
\text { afetam mais diretamente sua operação? } \\
\text { - disponibilidade dos serviços; } \\
\text { - técnico (necessita tecnologia que não está } \\
\text { disponível); } \\
\text { - operacional (necessita revisões de processos } \\
\text { que estão além da capacitação da equipe); } \\
\text { - como os profissionais obtiveram } \\
\text { conhecimento sobre os processos de } \\
\text { governança de TI; } \\
\text { - político; } \\
\text { - como se deu a aceitação/participação das } \\
\text { pessoas no processo de certificação; } \\
\text { - qual o papel dos gestores na manutenção das } \\
\text { práticas e da certificação ISO 20.000. }\end{array}$ & $\begin{array}{l}\text { Alves e Cherobim (2004); } \\
\text { Kobelsky; Hunter e Richardson } \\
\text { (2008); Wilkin e Chenhall (2010) }\end{array}$ \\
\hline R7 & $\begin{array}{l}\text { Qual a atitude da organização perante o risco? } \\
\text { - objetivos mudam constantemente; } \\
\text { - sentimento quanto a mudanças constantes; } \\
\text { - há busca de novos produtos e serviços ao } \\
\text { mercado, de maneira proativa; } \\
\text { - há tolerância a erros e novas tentativas. }\end{array}$ & $\begin{array}{l}\text { Hofstede (1991) apud Dutra et al. } \\
(2008)\end{array}$ \\
\hline R8 & $\begin{array}{l}\text { Como os ativos de TI (equipamentos, } \\
\text { software, processos, etc.) são controlados? } \\
\text { - controles manuais; } \\
\text { - processo de gerenciamento de configuração. }\end{array}$ & ISACA (2012) \\
\hline R9 & $\begin{array}{l}\text { Como são utilizados os relatórios gerados nos } \\
\text { processos para análise de melhoria? } \\
\text { - não são gerados relatórios; } \\
\text { - apenas geração de informação, sem análise; } \\
\text { - análise formalizada; } \\
\text { - reuniões de acompanhamento; }\end{array}$ & ISACA (2012) \\
\hline
\end{tabular}




\begin{tabular}{|c|c|c|}
\hline Número & Questão & Referência \\
\hline & $\begin{array}{l}\text { - planos de ação e melhoria, com } \\
\text { acompanhamento de seu andamento. }\end{array}$ & \\
\hline R10 & $\begin{array}{l}\text { Como são controladas e comunicadas } \\
\text { mudanças nos processos de governança de TI? } \\
\text { - não há processo definido; } \\
\text { - mudanças são feitas ad hoc; } \\
\text { - há controle das mudanças, mas não } \\
\text { formalizado nem para todas as mudanças; } \\
\text { - processo definido, mas com erros na } \\
\text { execução; } \\
\text { - processo definido e medido através de } \\
\text { relatórios; } \\
\text { - processo definido, interage com outros } \\
\text { processos de governança de TI e seu } \\
\text { desempenho é medido com relação ao } \\
\text { negócio. }\end{array}$ & ISACA (2012) \\
\hline R11 & $\begin{array}{l}\text { Quais regulamentações internas interferem } \\
\text { diretamente nas práticas de governança de TI? } \\
\text { - board; } \\
\text { - matriz/filiais; } \\
\text { - políticas de segurança/qualidade; } \\
\text { - acionistas. }\end{array}$ & ISACA (2012) \\
\hline
\end{tabular}

Tabela 16 - Roteiro de entrevistas com questões sobre desempenho.

\begin{tabular}{|c|c|c|}
\hline Número & Questão & Referência \\
\hline D1 & $\begin{array}{l}\text { Como se dão as relações com os parceiros da } \\
\text { organização? } \\
\text { - trabalho conjunto; } \\
\text { - processo formalizado para relacionamento; } \\
\text { - compartilhamento de riscos; } \\
\text { - estabelecimento de confiança; } \\
\text { - critério de seleção (qualidade de entrega); } \\
\text { - tratamento das entregas. }\end{array}$ & $\begin{array}{l}\text { Bhatt e Grover (2005); Melville; } \\
\text { Kraemer e Gurbaxani (2004); } \\
\text { Singh (2008) }\end{array}$ \\
\hline
\end{tabular}




\begin{tabular}{|c|c|c|}
\hline Número & Questão & Referência \\
\hline D2 & $\begin{array}{l}\text { Como a organização dá foco aos requisitos do } \\
\text { cliente? } \\
\text { - qualidade percebida pelos clientes nos } \\
\text { serviços; } \\
\text { - consistência na documentação; } \\
\text { - serviço ao cliente; } \\
\text { - auditorias de qualidade realizadas pelo } \\
\text { cliente. }\end{array}$ & $\begin{array}{l}\text { Melville; Kraemer e Gurbaxani } \\
\text { (2004); Singh (2008) }\end{array}$ \\
\hline D3 & $\begin{array}{l}\text { Qual o foco do portfólio de serviços da } \\
\text { organização para se apresentar ao mercado? } \\
\text { - escolhas de HW/SW; } \\
\text { - posicionamento de mercado; } \\
\text { - posicionamento com relação aos } \\
\text { competidores (marcas, parceiros de } \\
\text { tecnologia). }\end{array}$ & $\begin{array}{l}\text { Henderson e Venkatraman } \\
\text { (1993) }\end{array}$ \\
\hline D4 & $\begin{array}{l}\text { Quais fatores são considerados diferenciais de } \\
\text { sua organização? } \\
\text { - arquitetura de TI; } \\
\text { - processos; } \\
\text { - conhecimento dos profissionais. }\end{array}$ & $\begin{array}{l}\text { Henderson e Venkatraman } \\
\text { (1993); Ko e Fink (2010) }\end{array}$ \\
\hline D5 & $\begin{array}{l}\text { Como se dão as relações com as outras áreas } \\
\text { administrativas da organização? } \\
\text { - processos de negócio; } \\
\text { - priorizações de negociações e recursos para } \\
\text { objetivos de TI. }\end{array}$ & $\begin{array}{l}\text { Melville; Kraemer e Gurbaxani } \\
(2004)\end{array}$ \\
\hline D6 & $\begin{array}{l}\text { Quais são os principais problemas enfrentados } \\
\text { com o gerenciamento do desempenho da TI? } \\
\text { - medidas de aspectos tangíveis e intangíveis; } \\
\text { - relacionamento com satisfação do cliente; } \\
\text { - avaliações do board. }\end{array}$ & $\begin{array}{l}\text { de Haes e Van Grembergen } \\
\text { (2010); ISACA (2012); Wilkin e } \\
\text { Chenhall (2010) }\end{array}$ \\
\hline
\end{tabular}




\begin{tabular}{|c|c|c|}
\hline Número & Questão & Referência \\
\hline D7 & $\begin{array}{l}\text { Como são entendidas as demandas específicas } \\
\text { dos clientes? } \\
\text { - conhecimento sobre os requisitos; } \\
\text { - processos para melhoria da satisfação do } \\
\text { cliente; } \\
\text { - revisão de requisitos de contrato; } \\
\text { - processo de registro e tratamento de } \\
\text { reclamações. }\end{array}$ & Singh (2008) \\
\hline D8 & $\begin{array}{l}\text { Como são escolhidas e desenvolvidas as } \\
\text { competências dos profissionais? } \\
\text { - profissionais são treinados / desenvolvidos; } \\
\text { - profissionais conhecem seus objetivos e } \\
\text { papéis; } \\
\text { - profissionais sabem como as políticas da } \\
\text { organização afetam seu trabalho; } \\
\text { - há promoção da motivação dos profissionais; } \\
\text { - profissionais participam da definição de } \\
\text { planos estratégicos e operacionais; } \\
\text { - profissionais melhoram continuamente suas } \\
\text { atividades; } \\
\text { - atitudes dos gestores para manutenção dos } \\
\text { processos, quanto a comunicação, } \\
\text { acompanhamento e cobrança. }\end{array}$ & $\begin{array}{l}\text { Bulchand-Gidumal e Melián- } \\
\text { González (2011); de Haes e } \\
\text { Van Grembergen (2010); } \\
\text { Henderson e Venkatraman } \\
\text { (1993); Melville; Kraemer e } \\
\text { Gurbaxani (2004); Nfuka e } \\
\text { Rusu (2011); Singh (2008); } \\
\text { Zwicker et al. (2007) }\end{array}$ \\
\hline D9 & $\begin{array}{l}\text { Como se dão os programas de treinamento? } \\
\text { - ações para captura de lições aprendidas após } \\
\text { problemas reais da operação; } \\
\text { - comunicação dos dados sobre a qualidade } \\
\text { dos serviços; } \\
\text { - quando há mudanças em procedimentos as } \\
\text { versões são corretamente atualizadas e } \\
\text { informadas aos profissionais. }\end{array}$ & $\begin{array}{l}\text { Bhatt e Grover (2005); Senge } \\
\text { (2006); Singh (2008) }\end{array}$ \\
\hline
\end{tabular}




\begin{tabular}{|c|c|c|}
\hline Número & Questão & Referência \\
\hline D10 & $\begin{array}{l}\text { Quais são os processos para evidenciar os } \\
\text { resultados de negócio? } \\
\text { - objetivos medidos em verificações são } \\
\text { atingidos em sua maioria; } \\
\text { - serviços são medidos com relação aos } \\
\text { requisitos iniciais dos clientes; } \\
\text { - preocupação e cuidados com materiais e } \\
\text { equipamentos relacionados à entrega de } \\
\text { serviços de TI. }\end{array}$ & $\begin{array}{l}\text { Henderson e Venkatraman } \\
\text { (1993); Singh (2008) }\end{array}$ \\
\hline D11 & $\begin{array}{l}\text { Como e por quem é avaliado o desempenho da } \\
\text { organização? } \\
-\quad \text { acompanhamento sobre os custos } \\
\text { relacionados à qualidade da entrega; } \\
\text { - taxa de serviços com problemas; } \\
\text { - confiabilidade e desempenho dos serviços } \\
\text { entregues. }\end{array}$ & $\begin{array}{l}\text { Melville; Kraemer e Gurbaxani } \\
\text { (2004); Singh (2008) }\end{array}$ \\
\hline D12 & $\begin{array}{l}\text { Como é feito o planejamento para } \\
\text { investimentos em TI? } \\
\text { - reavaliação de investimentos ao longo do } \\
\text { período; } \\
\text { - comprometimento da alta direção com a } \\
\text { qualidade; } \\
\text { - alta direção é responsabilizada pela má } \\
\text { qualidade dos serviços; } \\
\text { - há revisões regulares pela gerência do } \\
\text { sistema de governança de TI; } \\
\text { - avaliação da melhoria contínua dos } \\
\text { processos; } \\
\text { - auditorias internas de qualidade. }\end{array}$ & $\begin{array}{l}\text { Henderson e Venkatraman } \\
\text { (1993); ISACA (2012); Singh } \\
\text { (2008); Soh e Markus (1995); } \\
\text { Wilkin e Chenhall (2010); } \\
\text { Zwicker et al. (2007) }\end{array}$ \\
\hline D13 & $\begin{array}{l}\text { Qual a importância da ISO } 20.000 \text { para sua } \\
\text { organização atualmente? }\end{array}$ & $\begin{array}{l}\text { Bulchand-Gidumal e } \text { Melián- } \\
\text { González (2011); ISACA } \\
\text { (2012); Soh e Markus (1995); }\end{array}$ \\
\hline
\end{tabular}




\begin{tabular}{|c|c|c|}
\hline Número & Questão & Referência \\
\hline & $\begin{array}{l}\text { - Impactos principais dos serviços de TI para } \\
\text { os negócios dos clientes da organização. }\end{array}$ & $\begin{array}{l}\text { Stevenson e Barnes (2002); } \\
\text { Wilkin e Chenhall (2010) }\end{array}$ \\
\hline D14 & $\begin{array}{l}\text { Como é adquirida e mantida a infraestrutura } \\
\text { de TI, que apoia os serviços? } \\
\text { - escolhas para configurações de hardware, } \\
\text { software, aplicações; } \\
\text { - criação de novos produtos e serviços. }\end{array}$ & $\begin{array}{l}\text { Bhatt e Grover (2005); } \\
\text { Bulchand-Gidumal e Melián- } \\
\text { González (2011); Soh e Markus } \\
(1995)\end{array}$ \\
\hline
\end{tabular}

Foram incluídas questões para investigar algumas características sobre os indivíduos, complementando a relação risco versus desempenho conforme discutido na Seção 2.4. Estas questões buscam informações sobre os quatro fatores: visibilidade das ações, controle, conformidade às regras e reflexão em prática, conforme a Figura 4.

Para a primeira fase, foi feito um piloto com apenas uma organização observando o texto da carta de apresentação e as questões apresentadas, de modo a testar o entendimento do interlocutor. Neste piloto, o respondente recebeu a carta de apresentação juntamente com o link para o questionário por e-mail após aviso pessoal de que isto iria ocorrer. As respostas ao questionário foram dadas sem acompanhamento ou monitoração pelo pesquisador, para não interferir no processo de entendimento individual das questões, o que precisava ser avaliado (WALSHAM apud SACCOL, 2005).

Após as respostas, pediu-se feedback do participante através de conversa individual. Deste modo foi possível melhorar a elaboração da versão eletrônica do questionário antes de divulgálo amplamente para outros participantes: erro na quantidade de alternativas possíveis de escolha e entendimento de enunciados. A transcrição das entrevistas foi feita no intervalo máximo de quarenta e oito horas, para que não se perdesse o entendimento.

Alguns pontos de destaque que não faziam parte da análise inicial foram descritos nos relatos dos estudos de caso. Pela abertura proposta no método de entrevistas, novas informações surgiram e puderam enriquecer a análise, citando Selltiz et al. (1965): "um estudo não está 
totalmente cristalizado quando se formula o problema de pesquisa (...) ainda pode haver espaço para a inclusão de subsequentes aperfeiçoamentos”.

Foi proposta uma análise entre os casos, através da categorização dos dados de acordo com a estruturação proposta no roteiro de entrevistas da Tabela 15 e Tabela 16. Para tanto foi usado o método proposto por Yin (2009) de síntese de cruzamento de casos, complementado com técnicas quantitativas obtidas através dos questionários da primeira fase e das opções de respostas referenciadas em literatura da segunda fase, como em meta-análise proposta por Lipsey (1992).

\subsection{Critérios para interpretar as descobertas da pesquisa}

Como contrapontos ao método de estudos de casos, Yin (2009) cita quatro fatores quanto a limitação de seu uso:

- $\quad$ Falta de rigor do estudo de caso: quando o método é pouco definido e durante a definição dos instrumentos de pesquisa, da coleta de dados e da análise estes são seguidos sem a devida rigidez;

- $\quad$ Pouca base para generalização científica: utilizando apenas os dados e o resultado de sua análise para extrapolar conclusões para todas as organizações;

- Tomam muito tempo e geram dados massivos: dificultando análises posteriores de outros pesquisadores para continuar a partir de resultados;

- $\quad$ Nova ênfase sobre testes de campo aleatórios (ou experimentos reais): maior busca sobre estudos que permitam estabelecimento de relações de causa-e-efeito.

Para diminuir estes pontos, as precauções tomadas nesta pesquisa foram descritas anteriormente, sendo sintetizadas em:

- Uso de questionário para orientar a pesquisa.

- $\quad$ Aplicação de questionário quantitativo antes das entrevistas, para melhor compreender quais campos a aprofundar, tornando-as mais produtivas. 
- $\quad$ Realização de piloto (com uma organização, primeira e segunda fase de coleta de dados) para validar o entendimento das questões, duração da entrevista e consistência do método de coleta de dados.

- Utilizar método anti viés para criação das perguntas da primeira e segunda fases, buscando consistência nas respostas.

- $\quad$ O próprio pesquisador realizou as entrevistas, transcrições, redação e análise dos casos.

- Uso de outras fontes para confirmar ou complementar informações obtidas (ex.: referências bibliográficas, websites, processos publicados em intranet).

Esta pesquisa apresenta limitações quanto a seus dados e sua interpretação de resultados, com base nas considerações de Bido (1999):

- $\quad$ Apesar dos procedimentos do pesquisador, as entrevistas apresentam uma visão parcial dos entrevistados sobre os temas.

- A pesquisa realizada é de natureza indutiva, sendo que sua análise depende muito do pesquisador e é impossível identificar todas as variáveis importantes.

- Dados não disponíveis já que, em determinadas situações, as organizações queriam manter sigilo mesmo tendo suas identidades não divulgadas nesta pesquisa.

Os resultados desta pesquisa não podem ser generalizados de maneira estatística. Porém, dada a construção do referencial teórico e dos métodos de coleta e a análise propostos os resultados podem ser generalizados para proposições teóricas, como proposto no método de Webster e Watson (2002), apresentado na Figura 11. Podem atender, por exemplo, a leitores como um administrador de uma organização que precisa decidir se investirá na obtenção de uma certificação formal, ou na utilização de referenciais de melhores práticas para os processos de governança de TI. 


\section{COLETA DE DADOS: FASE 1 - QUESTIONÁRIO}

Do total de 27 empresas certificadas ISO 20.000 no Brasil, que constituem o universo desta pesquisa, foram obtidas respostas de 8 delas (30\% do universo), formando a amostra trabalhada.

A partir dos questionários respondidos, as informações foram formatadas em gráficos para facilitar a análise e sua comparação. Buscou-se estabelecer uma visão de como organizações certificadas ISO 20.000 estão qualificadas e como utilizam as práticas e modelos de referência de governança de TI.

As respostas aos questionários, gerenciados através da ferramenta web SurveyMonkey (Surveymonkey, 2014), foram revisadas de acordo com as confirmações feitas durante as entrevistas da segunda fase. Desta forma, se garantiu o entendimento adequado do entrevistado com relação às questões e suas respostas, bem como a coerência entre os questionários e as entrevistas. Os nomes dos participantes e de suas respectivas organizações foram suprimidos para manter sua confidencialidade.

Os gráficos foram gerados a partir da ferramenta SurveyMonkey e, com tratamento através de planilhas Microsoft Excel, divididos nas seções propostas no questionário da primeira fase, apresentado no Apêndice 2.

As questões de 9 a 20 do questionário da fase 1 são analisadas de maneira similar devido a sua estruturação. Foram calculados escores para cada resposta, sendo que a ordem de prioridade de 1 a 5 (ou 1 a 4) das opções de resposta foram utilizados como pesos: quanto mais importante no ponto de vista do respondente, maior o peso (LO et al., 2013; SINGH, 2008).

\subsection{Qualificadoras, priorização de processos e motivadores}

O primeiro critério de qualificação das organizações é seu tamanho, de acordo com o número de funcionários, conforme apresentado na Figura 12. 


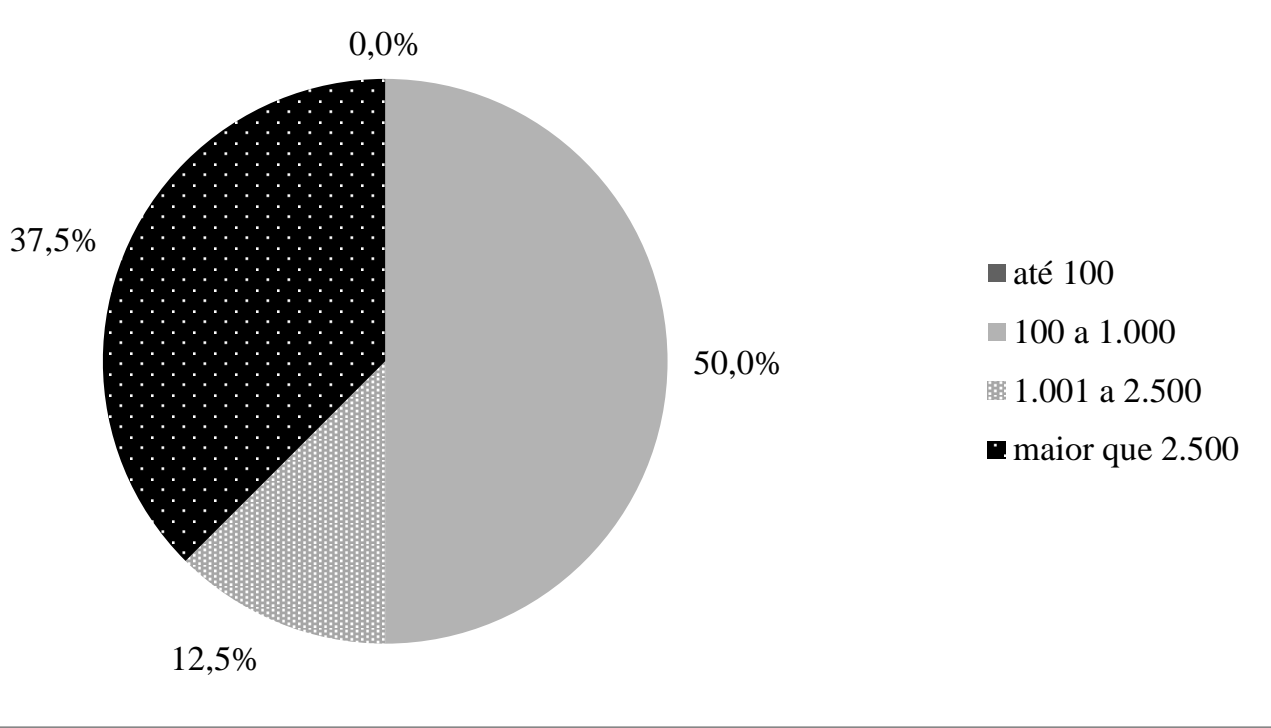

Figura 12 - Tamanho das organizações estudadas, em número de profissionais (Q4).

Quanto ao processo de decisão de investimentos em TI (Q5), metade dos entrevistados posiciona que as decisões são tomadas em conjunto pelos gestores da empresa com a área de negócio (alta direção ou direção do cliente atendido), conforme ilustrado na Erro! Fonte de referência não encontrada.. Nenhum dos entrevistados apontou que tais decisões vêm diretamente das áreas de negócio (áreas do cliente que pagam pelos serviços de TI) ou de áreas usuárias (profissionais que se utilizam dos serviços de TI). Nota-se que este posicionamento está de acordo com tendências de mercado recentes, como computação em nuvem (GARTNER, 2014; PRADO; SOUZA, 2014) e "consumerização" (IDC, 2013): as áreas de negócio passam a ter maior autonomia para a aquisição e utilização direta de soluções de tecnologia da informação. Para as organizações prestadoras de serviços de TI isso se apresenta como oportunidade de ter mais interlocutores e possíveis clientes.

Ao se comparar esta distribuição com os arquétipos de governança de TI de Weill e Ross (2004), nota-se a predominância do modelo federativo, em que os executivos (C-level) e as áreas de negócio, que podem incluir a área gestora da TI, detêm os direitos pelas decisões sobre TI. Metade dos entrevistados apontou o processo de decisão de investimentos de TI (Q5) como gestores da empresa ( $C$-level) em conjunto com as áreas de negócio, enquanto dois apontaram os gestores da empresa $(C$-level $)$ e outros dois a área de TI.

Segundo a Figura 13, nota-se que ITIL é o modelo de governança mais adotado, mostrando a relação intrínseca entre o conteúdo da norma (ISO 20.000) e este referencial, sendo voltado ao 
gerenciamento dos serviços de TI, bem como Cobit pela necessidade de complementar os indicadores de gestão, como analisado na Seção 3.7. PMBoK é voltado a gerenciamento de projetos, sendo que estes são parte intrínseca da natureza da entrega destes serviços pelas organizações estudadas: desenho, implantação e testes de soluções de TI.

Dentre os mais citados como não adotados, o modelo CMMI é voltado aos processos de desenvolvimento de software, que não necessariamente fazem parte do portfólio das organizações pesquisadas, e o modelo Seis Sigma voltado a métodos de qualidade para produção, apesar de possuir versões com enfoque em serviços.

Em comparação com a Figura 6, os três modelos mais adotados se mantêm os mesmos, apesar de em diferentes posições: ITIL, Cobit e PMBoK formam o conjunto de modelos de referência complementares.

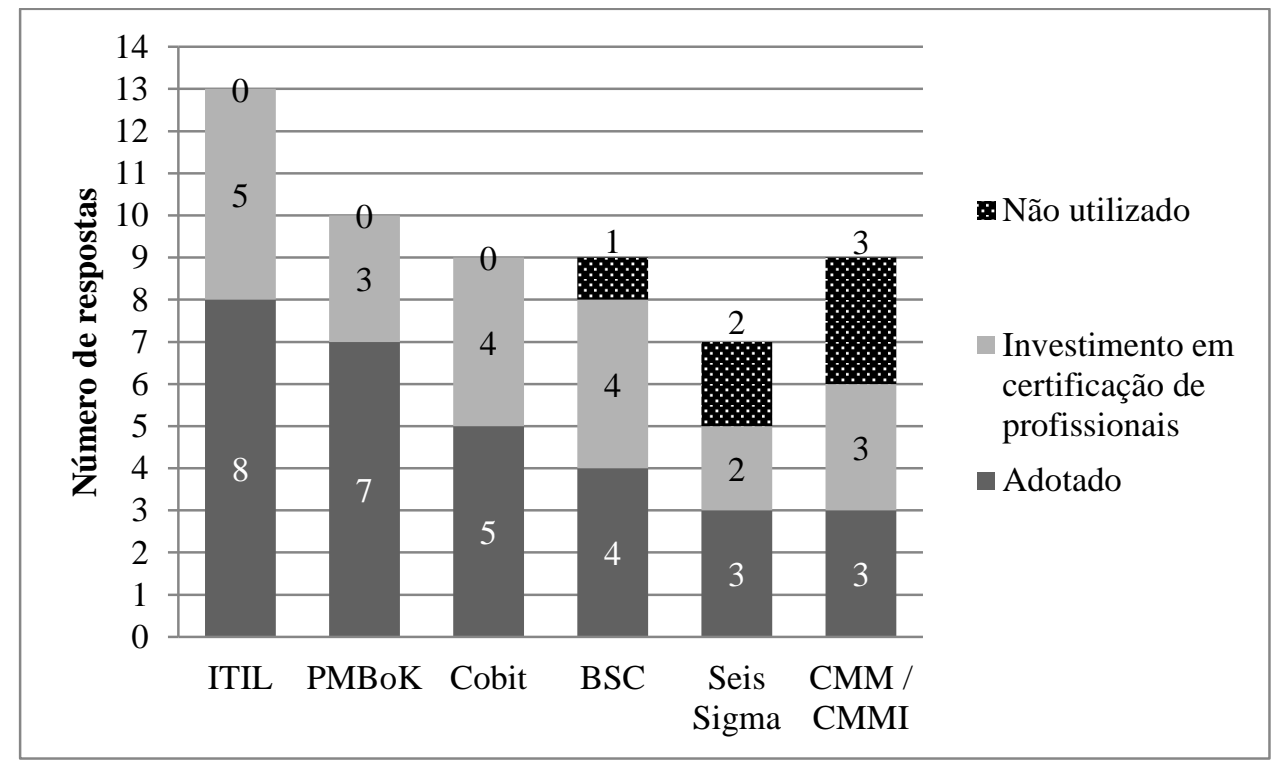

Figura 13 - Modelos de melhores práticas adotados pelas organizações estudadas (Q7).

Ao adotar o modelo canônico e buscar a certificação ISO 20.000, a maioria das organizações usou os próprios processos, adaptando-os aos requisitos necessários, como apresentado na Figura 14. Fato este também corroborado ilustrado na Figura 6. 


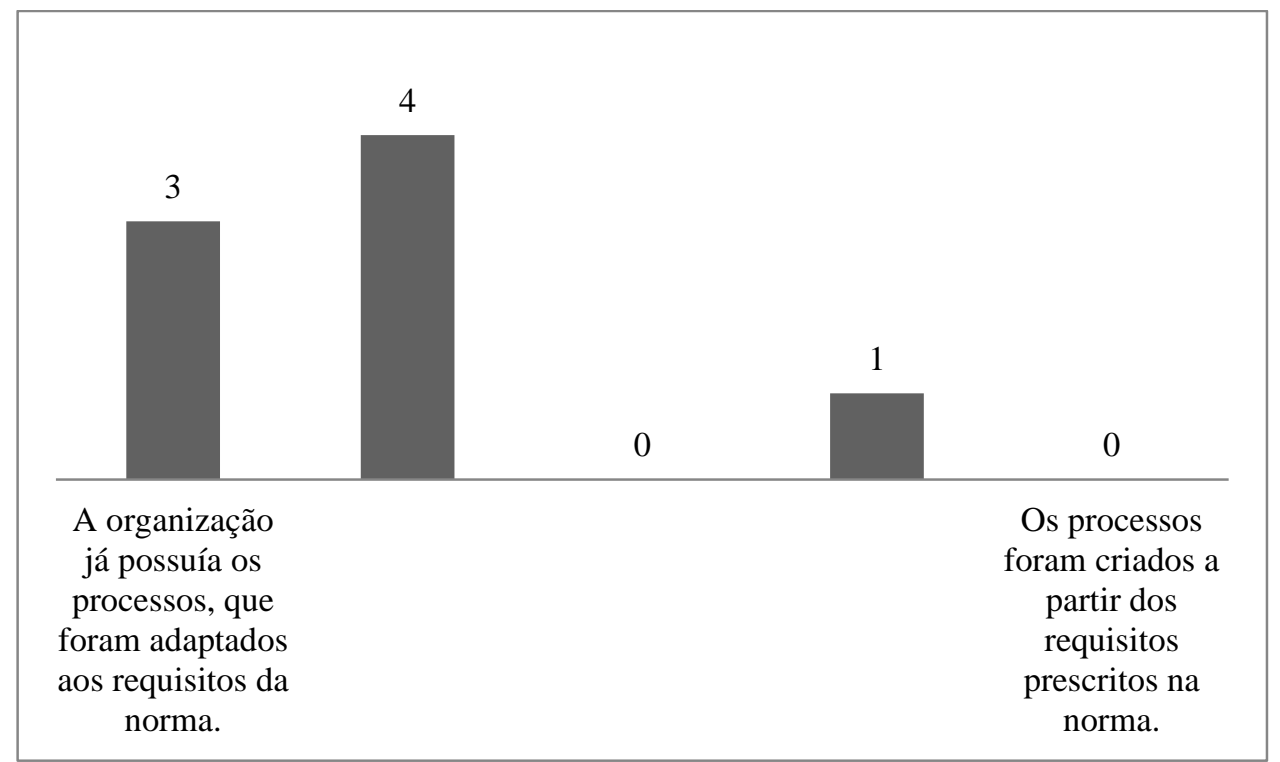

Figura 14 - Modelos de melhores práticas adotados pelas organizações estudadas (Q8).

A maioria das organizações já possuíam processos definidos e fizeram adaptações para se adequar ao modelo canônico de governança de TI. Uma das organizações citou que extraiu a maior parte dos processos da norma, pois poucos deles estavam implantados ou documentados. Assim foi encontrado um exemplo de organização que aplica a norma tal qual é prescrita, buscando a conformidade ao padrão, pelas motivações pesquisadas, ao invés de descrever seus processos com base em sua própria realidade.

\subsection{Riscos}

A relação dos riscos com a organização foi pesquisada inicialmente através de questões sobre a atitude típica diante dos mesmos $(\mathrm{Q} 17)$ e de oportunidades inovadoras com clientes (Q18), que normalmente provocam mudanças na maneira como a organização está acostumada a tratar os negócios. 


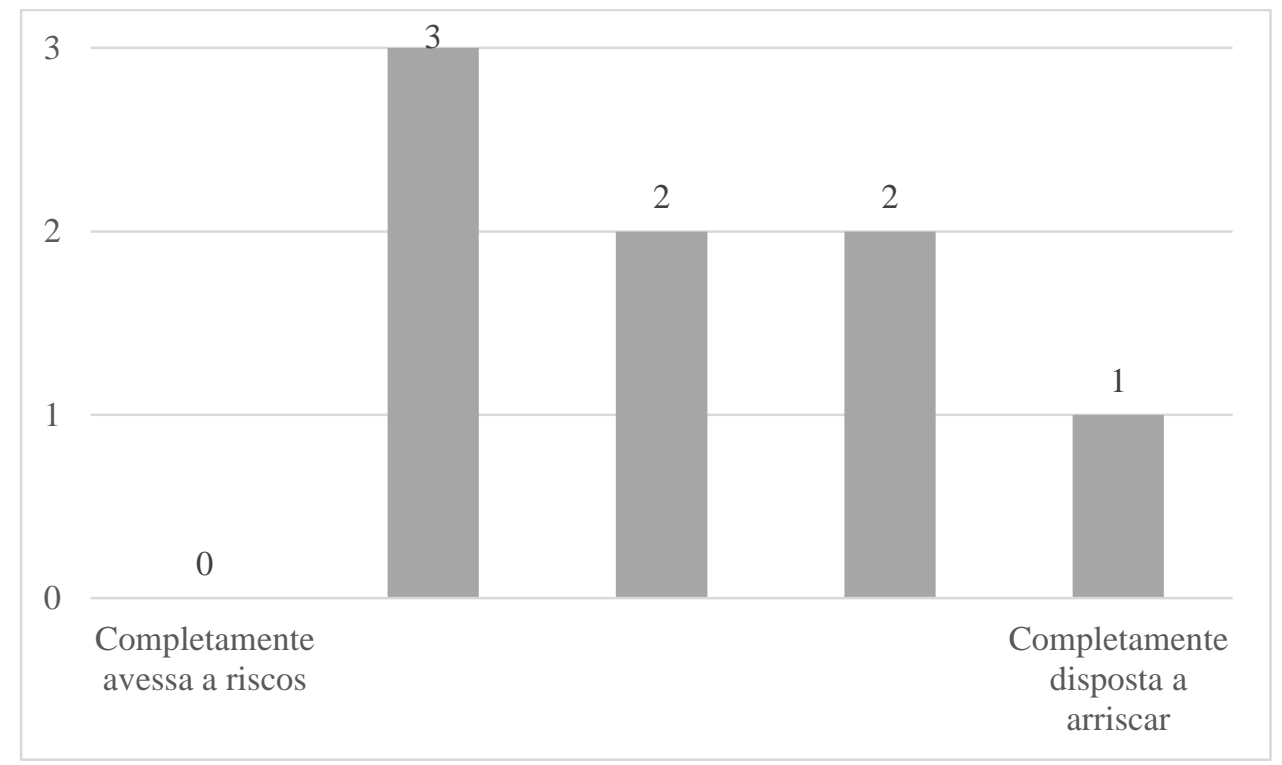

Figura 15 - Atitude típica da organização perante os riscos (Q17).

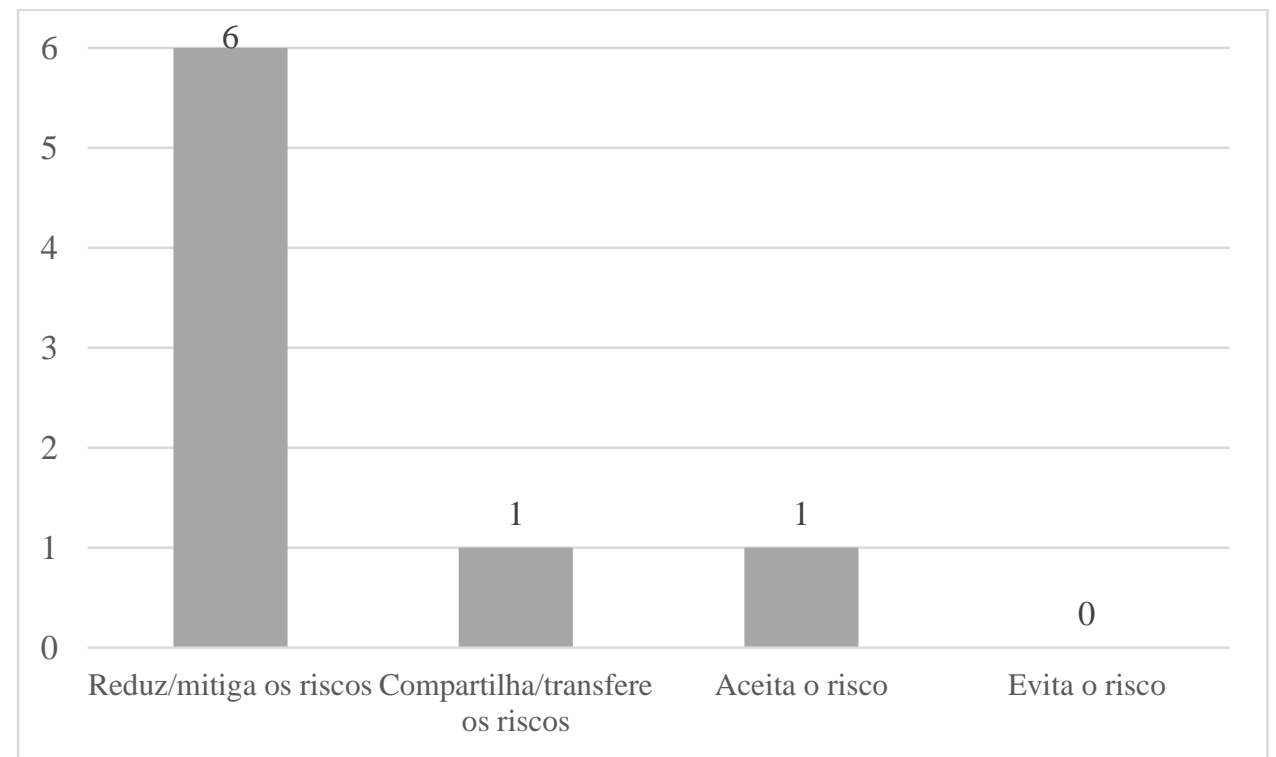

Figura 16 - Atitude típica da organização diante de uma oportunidade inovadora com um cliente (Q18).

Ao analisar estes dados em conjunto vê-se que as organizações estudadas têm grande tendência a arriscar pouco e tratar os riscos ao lidar com situações novas. Comparando estes dados com a cultura do país (HOFSTEDE, 2012), nota-se que as organizações estudadas seguem a mesma tendência da avaliação geral do país: o índice de aversão à incerteza (uncertainty avoidance index: UAI) medido pelo autor no Brasil vale 76 (na escala de 0 a 100) indicando que, de modo geral, no país se evita o risco como refletido na Figura 15. Ao comparar este indicador aos de outros países (HOFSTEDE, 2012) em que foram feitas pesquisas similares sobre governança de TI, nota-se semelhança com a Lituânia (RUZEVICIUS; ADOMAITIENE; SIRVIDAITE, 
2004), cujo índice vale 65 e tem maior número de empresas certificadas ISO 20.000 que a Suécia (GUSTAFSSON et al., 2001), apresentada em total oposição com relação ao índice UAI com 29 e alta tolerância à incerteza. Austrália (SINGH, 2008; TERZIOVSKI; POWER; SOHAL, 2003) e EUA (LO et al., 2013) apresentam índices parecidos entre si (51 e 46 respectivamente), indicando maior aceitação de riscos em relação ao Brasil.

Notou-se uma exceção a este fato ao cruzar os dados de tamanho da organização: as organizações de menor porte têm maior disposição a arriscar e aceitar riscos impostos pelos clientes em troca da possibilidade de ganhar o contrato e, consequentemente, crescer.

Para classificar os riscos, foram questionados fatores externos (Q15) e internos (Q16, Q19) à organização que poderiam interferir no desempenho dos serviços de TI, cujos resultados são apresentados nas figuras abaixo após cálculo de escores dos fatores de acordo com pesos atribuídos a sua importância relativa, conforme classificação fornecida pelos respondentes.

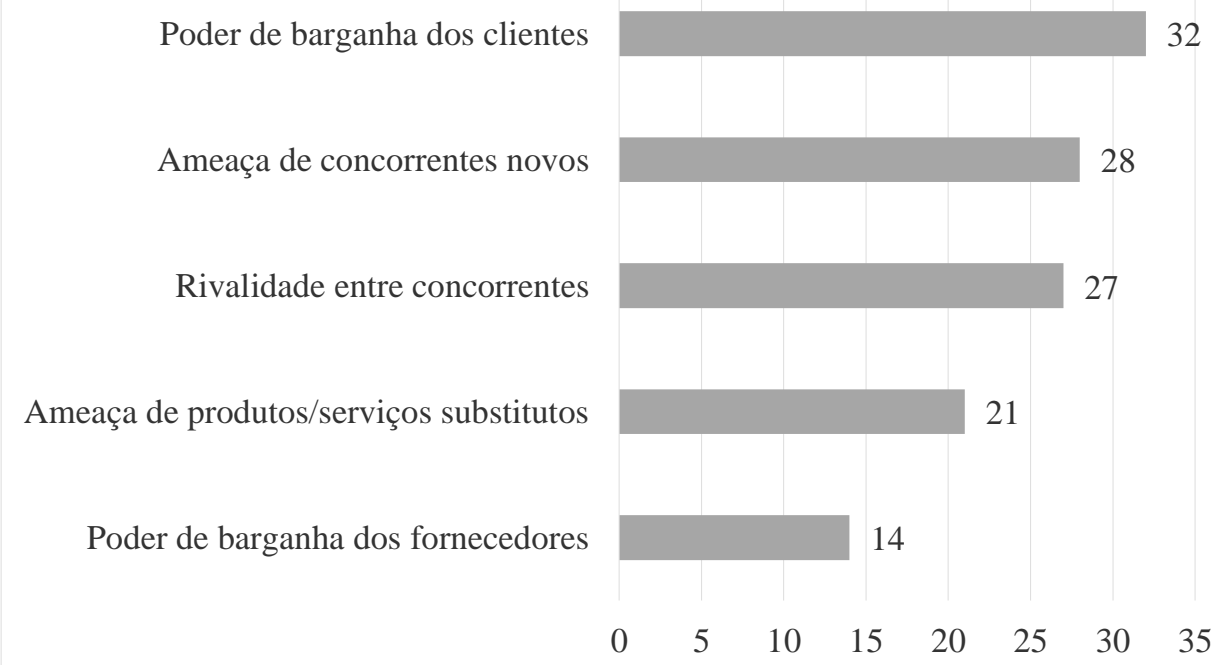

Figura 17 - Fatores externos à organização que têm impacto sobre o investimento de TI (Q15).

As necessidades de atender aos clientes e se posicionar contra os concorrentes geram os maiores riscos apontados pelos respondentes. Ao analisar estes dados à luz dos conceitos de Porter (CARVALHO; LAURINDO, 2006), nota-se a orientação das organizações para antederem aos requisitos dos clientes para que sem mantenham nos negócios. 


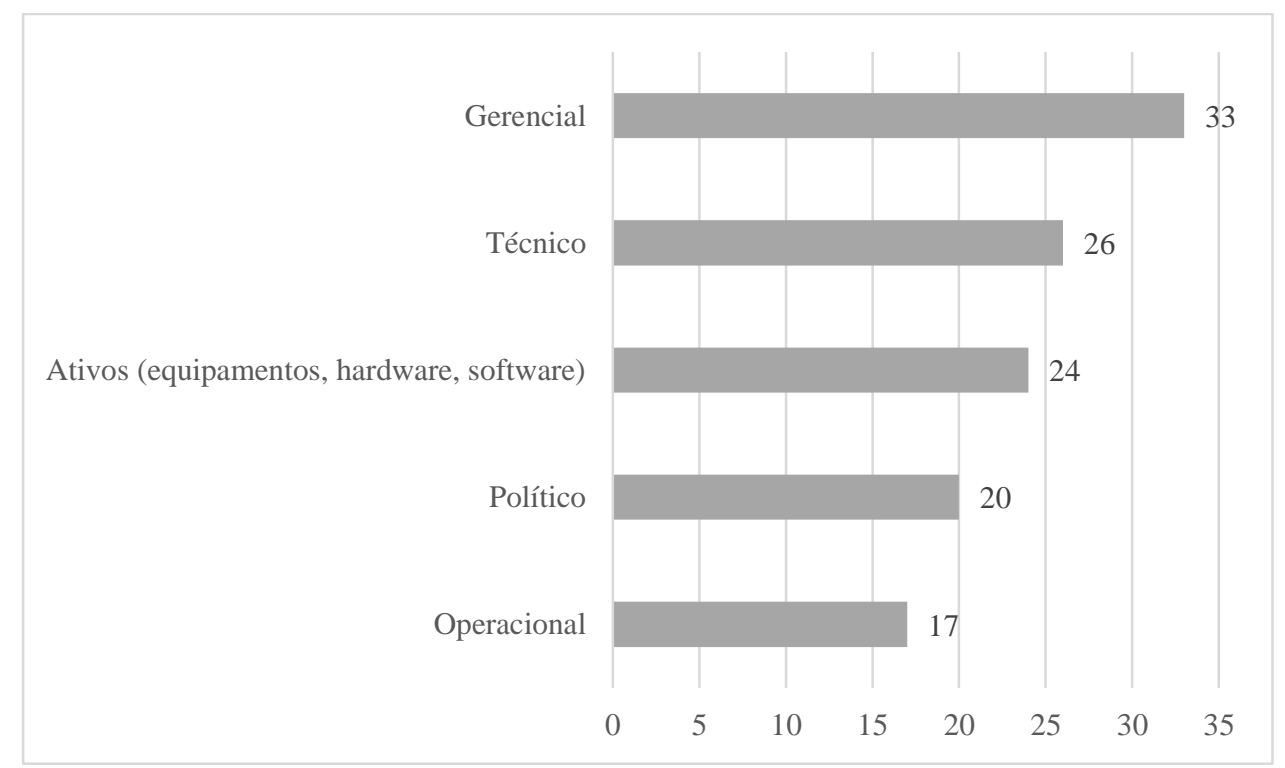

Figura 18 - Fatores internos à organização que têm impacto sobre o investimento de TI (Q16).

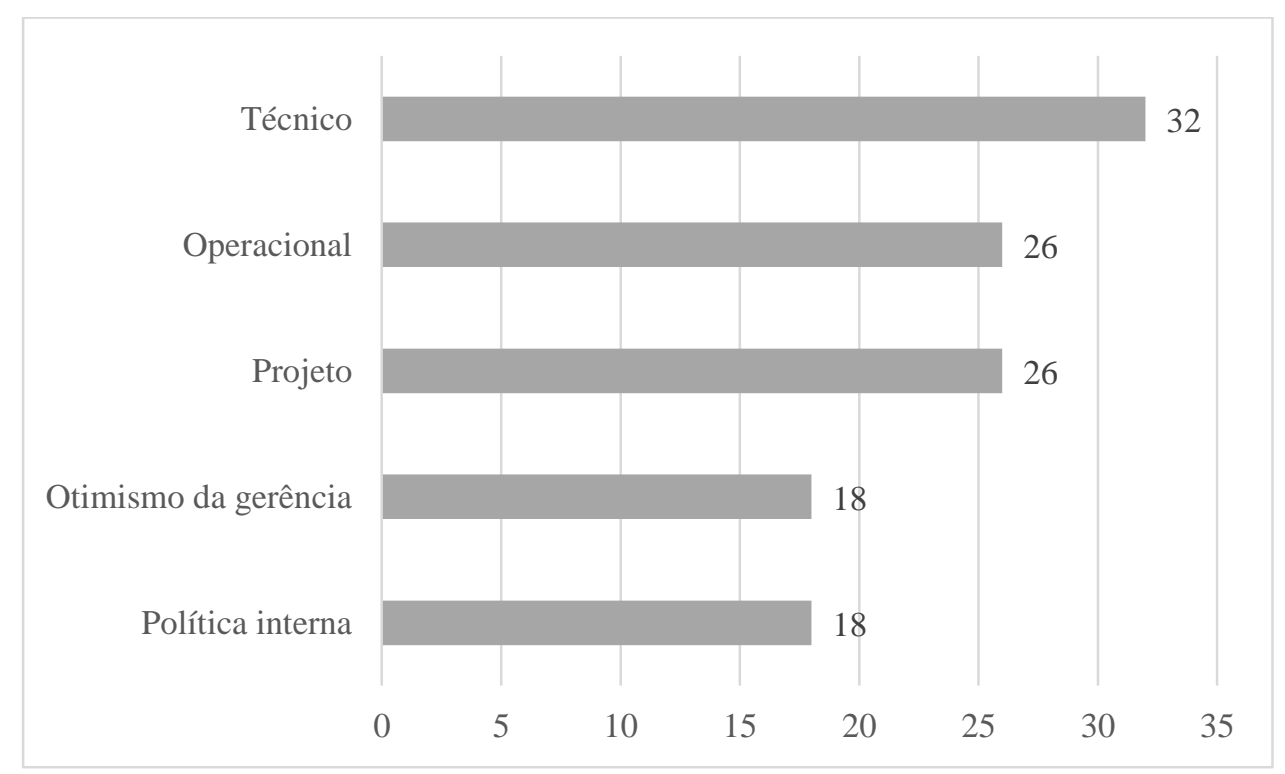

Figura 19 - Classificação de riscos internos à organização (Q19).

Internamente à organização, vê-se que o fator operacional apresenta-se como forte indicador de risco. Há ênfase nos aspectos técnico e operacional quanto a fontes de riscos internos, conforme Figura 19. Porém sua importância é diminuída quando se trata dos investimentos de TI (Figura 18). A dependência do desempenho nas pessoas que operam os serviços de TI é clara (conforme Seção 2.4), mas sua voz fica reduzida quando as decisões devem ser tomadas pela organização. Especificamente sobre a operação, foram classificados fatores de risco operacionais, apresentados na Figura 20. A interrupção dos negócios aparece em primeiro lugar por estar 
diretamente relacionada ao desempenho dos serviços de TI e consequente desempenho dos negócios e satisfação dos clientes.

O segundo fator apontado se refere à maneira como os processos são executados e seguidos, mostrando a preocupação dos líderes da organização em prescrever as atividades e o modo como devem ser executadas, exercendo assim maior controle sobre os profissionais, buscando reduzir erros operacionais e consistência na entrega.

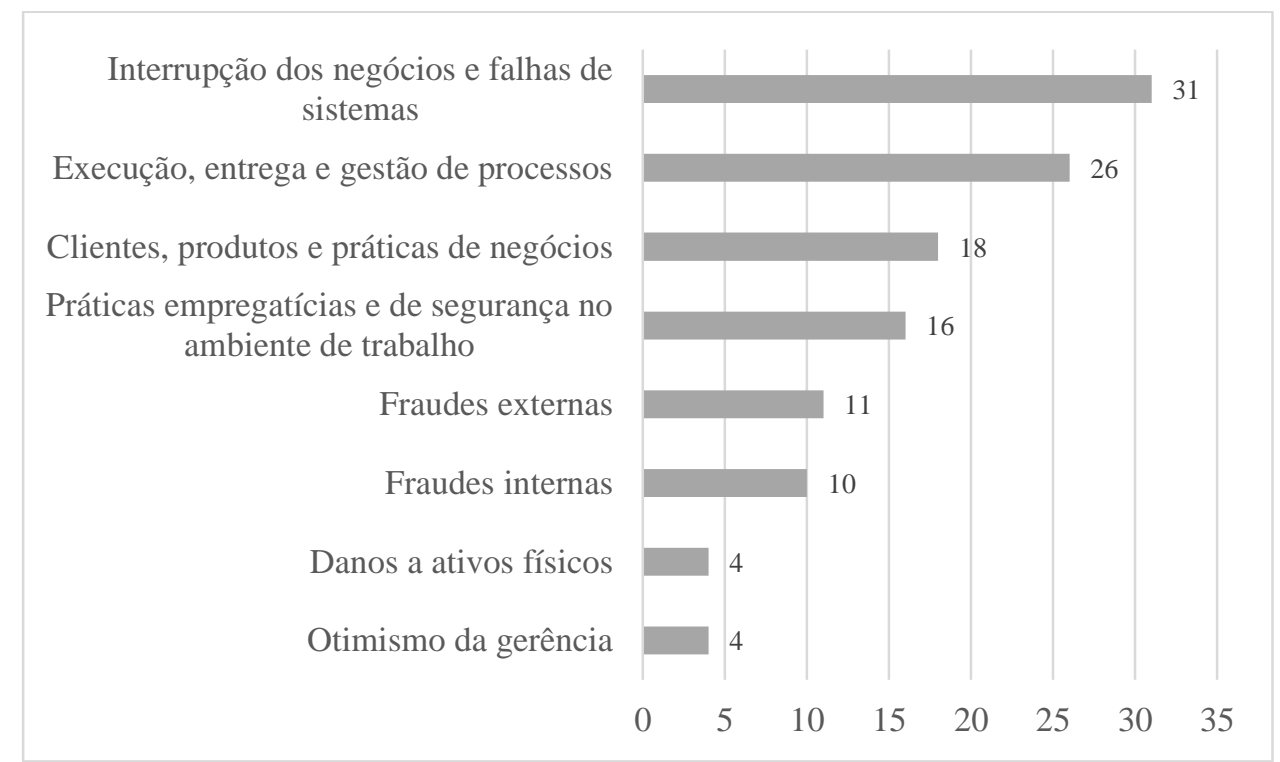

Figura 20 - Classificação de riscos operacionais (Q20).

\subsection{Desempenho}

As questões relacionadas a desempenho buscaram informações sobre fatores críticos de sucesso, benefícios, melhorias e dificuldades, de acordo com seu agrupamento apresentado no Apêndice 2. A Figura 21 apresenta a importância relativa dada aos processos do modelo canônico de governança de TI com relação ao impacto causado a suas operações de TI. 


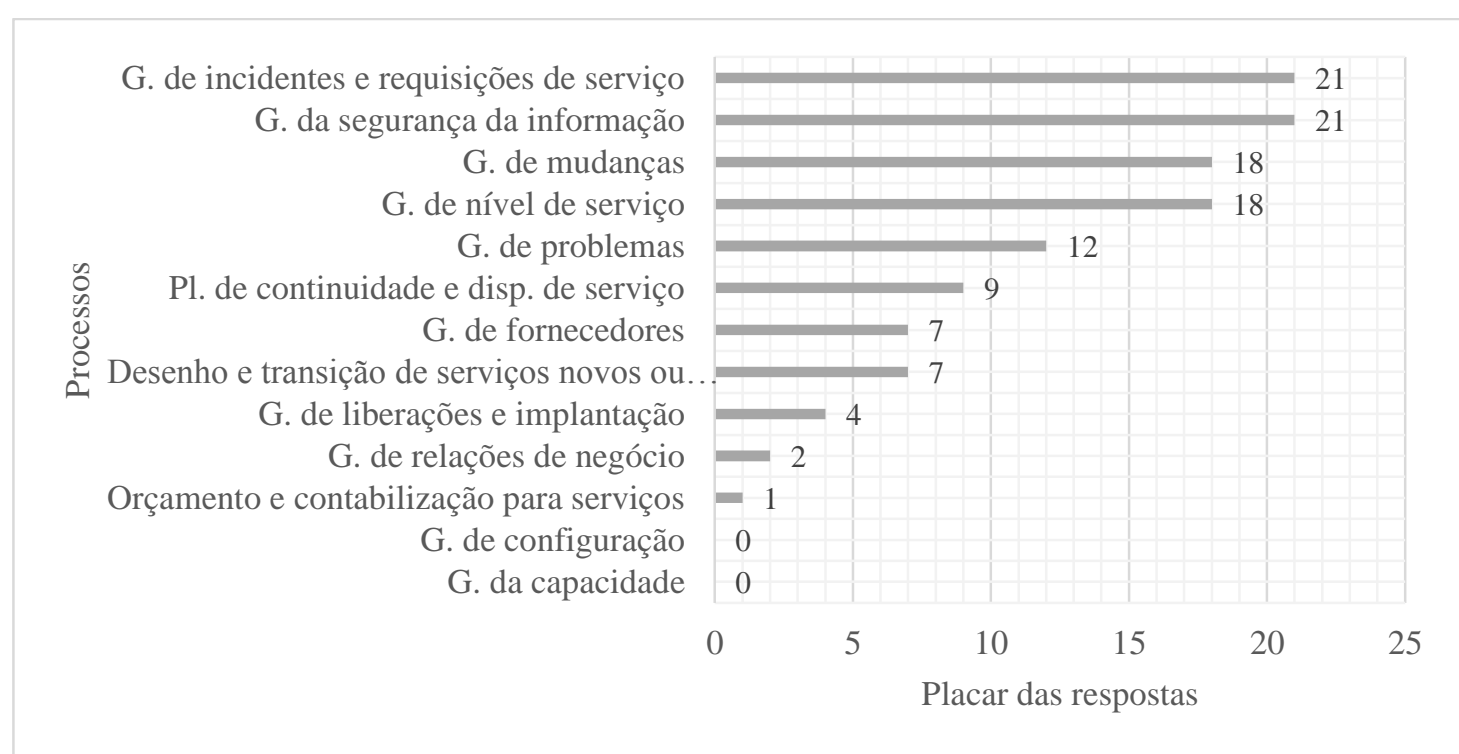

Figura 21 - Processos da norma ISO 20.000 considerados como tendo maior impacto nas operações de TI (Q9).

Usando análise de Pareto (HAIR JR. et al., 2009) sobre os escores obtidos, nota-se que os processos apontados em maior destaque são apresentados na Tabela 17. Analisando os objetivos destes processos tais como documentados na norma ISO 20.000, pode-se categorizá-los em voltados a entregas de serviços imediatamente visíveis pelos clientes finais ou à mitigação de riscos.

Tabela 17 - Processos da norma ISO 20.000 apontados como principais na pesquisa e seus objetivos relacionados a desempenho e risco.

\begin{tabular}{|c|c|c|c|}
\hline \multirow{2}{*}{$\begin{array}{l}\text { Ordem } \\
\text { na } \\
\text { pesquisa }\end{array}$} & \multirow[t]{2}{*}{ Processo } & \multicolumn{2}{|c|}{ Objetivo principal } \\
\hline & & $\begin{array}{c}\text { Desempenho } \\
\text { (cumprir objetivos) }\end{array}$ & Riscos (mitigação) \\
\hline $1^{\mathrm{o}}$ & $\begin{array}{l}\text { Gerenciamento de incidentes } \\
\text { e requisições de serviço }\end{array}$ & $X$ & - \\
\hline $2^{\underline{o}}$ & $\begin{array}{l}\text { Gerenciamento da segurança } \\
\text { da informação }\end{array}$ & - & $\mathrm{X}$ \\
\hline $3^{\underline{o}}$ & Gerenciamento de mudanças & - & $\mathrm{X}$ \\
\hline $4^{\mathrm{o}}$ & $\begin{array}{l}\text { Gerenciamento de nível de } \\
\text { serviço }\end{array}$ & $X$ & - \\
\hline $5^{0}$ & $\begin{array}{l}\text { Gerenciamento de } \\
\text { problemas }\end{array}$ & $X$ & $\mathrm{X}$ \\
\hline
\end{tabular}


O destaque, portanto, se dá a processos que apresentem resultados mais imediatos aos clientes, refletindo em sua satisfação e no desempenho da organização, ou em atividades que possam ajudar a mitigar riscos. Os outros processos são colocados em segundo plano para que se obtenha resultados práticos e rápidos da utilização do modelo canônico de governança de TI.

Apesar do processo de gerenciamento de fornecedores aparecer em algumas opiniões pesquisadas, a busca de fornecedores confiáveis não foi destacada entre os fatores mais importantes para o sucesso da adoção e da manutenção do uso da norma ISO 20.000 em sua organização (Q11), como visto na Figura 22.

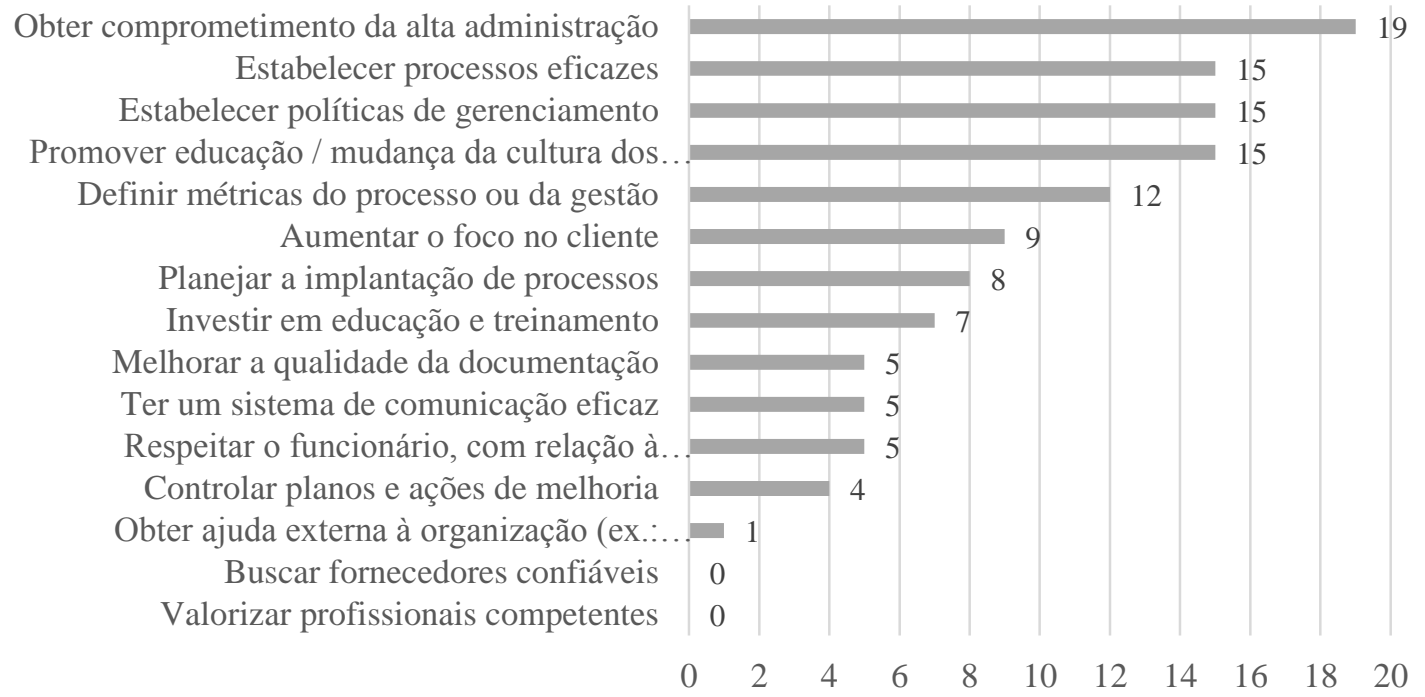

Figura 22 - Fatores mais importantes para o sucesso da adoção e da manutenção do uso da norma ISO $20.000(Q 11)$.

Ouvir o cliente e fazer com que os processos sejam estabelecidos, controlados e seguidos a partir da alta direção da organização se apresentam como fatores determinantes no seu sucesso. Manter as pessoas informadas não só tecnicamente das atividades a elas atribuídas, mas também de seus objetivos e da importância de suas tarefas para a satisfação dos clientes tem relação direta com o sucesso da prestação de serviços de TI.

As métricas dos processos são o instrumento de comunicação mais eficaz entre as áreas e a alta administração, mostrando a conformidade aos processos e os resultados que são obtidos. 
Utilizando análise de Pareto sobre estes dados segundo referência de outros estudos (SASAKI, 2001; SINGH, 2008), conforme ilustrado na Tabela 18, vê-se uma tendência na valorização dos processos sobre as pessoas, confirmado no critério D4 utilizado na entrevista da segunda fase.

Tabela 18 - Fatores de sucesso na adoção e da manutenção do uso da norma ISO 20.000 apontados como principais na pesquisa $(Q 11)$.

\begin{tabular}{|c|l|c|c|}
\hline $\begin{array}{c}\text { Ordem na } \\
\text { pesquisa }\end{array}$ & Fator de sucesso & Processos & Pessoas \\
\hline $1^{\underline{0}}$ & Obter comprometimento da alta administração & - & $\mathrm{X}$ \\
\hline $2^{\underline{0}}$ & Estabelecer processos eficazes & $\mathrm{X}$ & - \\
\hline $3^{\underline{0}}$ & Estabelecer políticas de gerenciamento & $\mathrm{X}$ & - \\
\hline $4^{\underline{0}}$ & $\begin{array}{l}\text { Promover educação / mudança da cultura dos } \\
\text { funcionários }\end{array}$ & - & $\mathrm{X}$ \\
\hline $5^{\underline{0}}$ & Definir métricas do processo ou da gestão & $\mathrm{X}$ & - \\
\hline $6^{\underline{0}}$ & Aumentar o foco no cliente & $\mathrm{X}$ & - \\
\hline $7^{\underline{0}}$ & Planejar a implantação de processos & \\
\hline
\end{tabular}

Como contraponto de análise, foram buscadas informações sobre quais as razões e motivos para a busca da certificação ISO 20.000 (Q10), mas também as principais dificuldades em mantê-la (Q14). Como principais motivadores (Q10) são apontados mercado e clientes para a busca e a manutenção da certificação ISO 20.000, ilustrado na Figura 23. As questões regulatórias internas aparecem mostrando a interação entre os sistemas de governança corporativa e de TI, estabelecendo como apresentado na Tabela 2. 


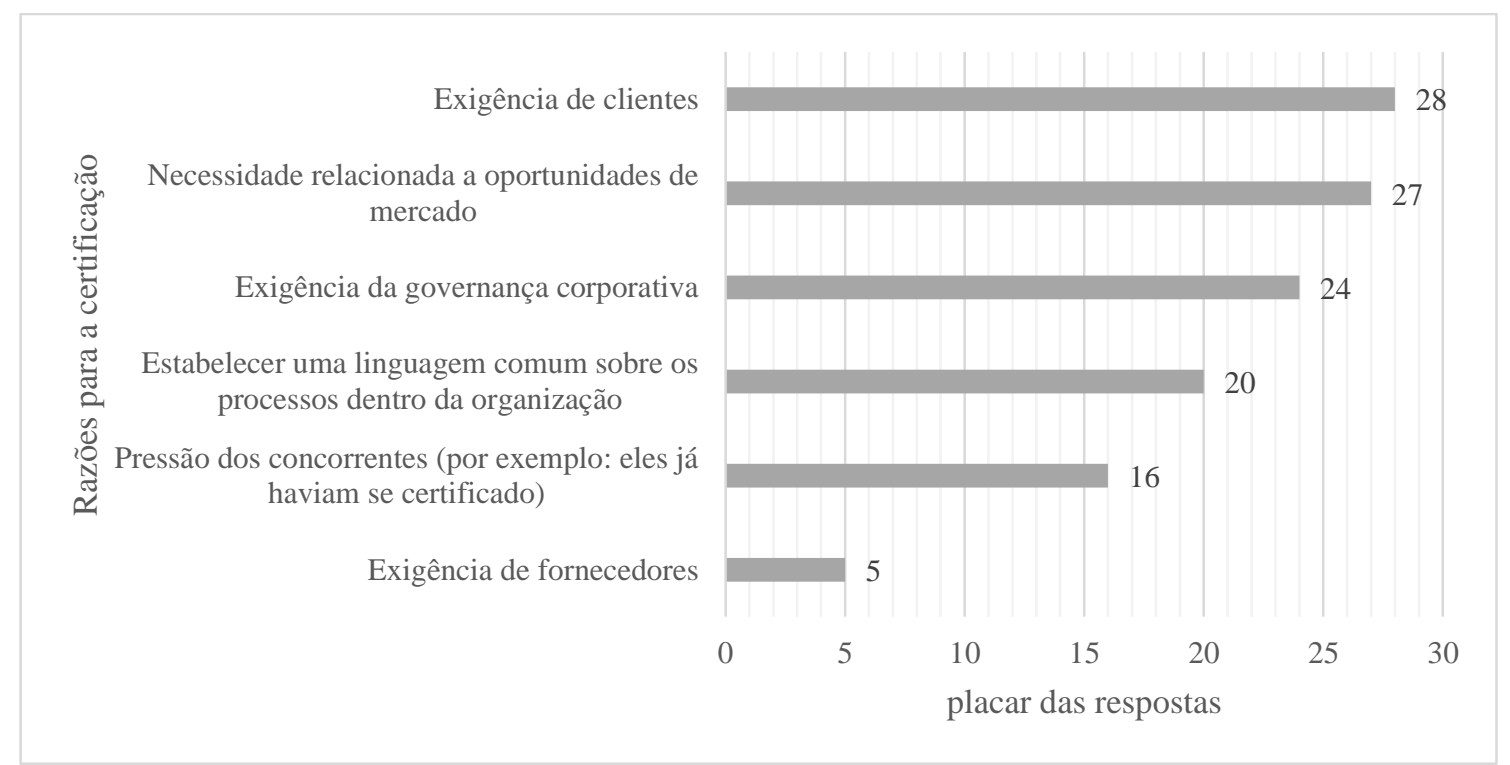

Figura 23 - Motivos mais importantes pelos quais as organizações se certificaram e se mantêm em conformidade com a norma ISO $20.000(Q 10)$.

Sobre as dificuldades para manter o sistema de gerenciamento de serviços conforme prescrito, as respostas foram ilustradas na Figura 24.

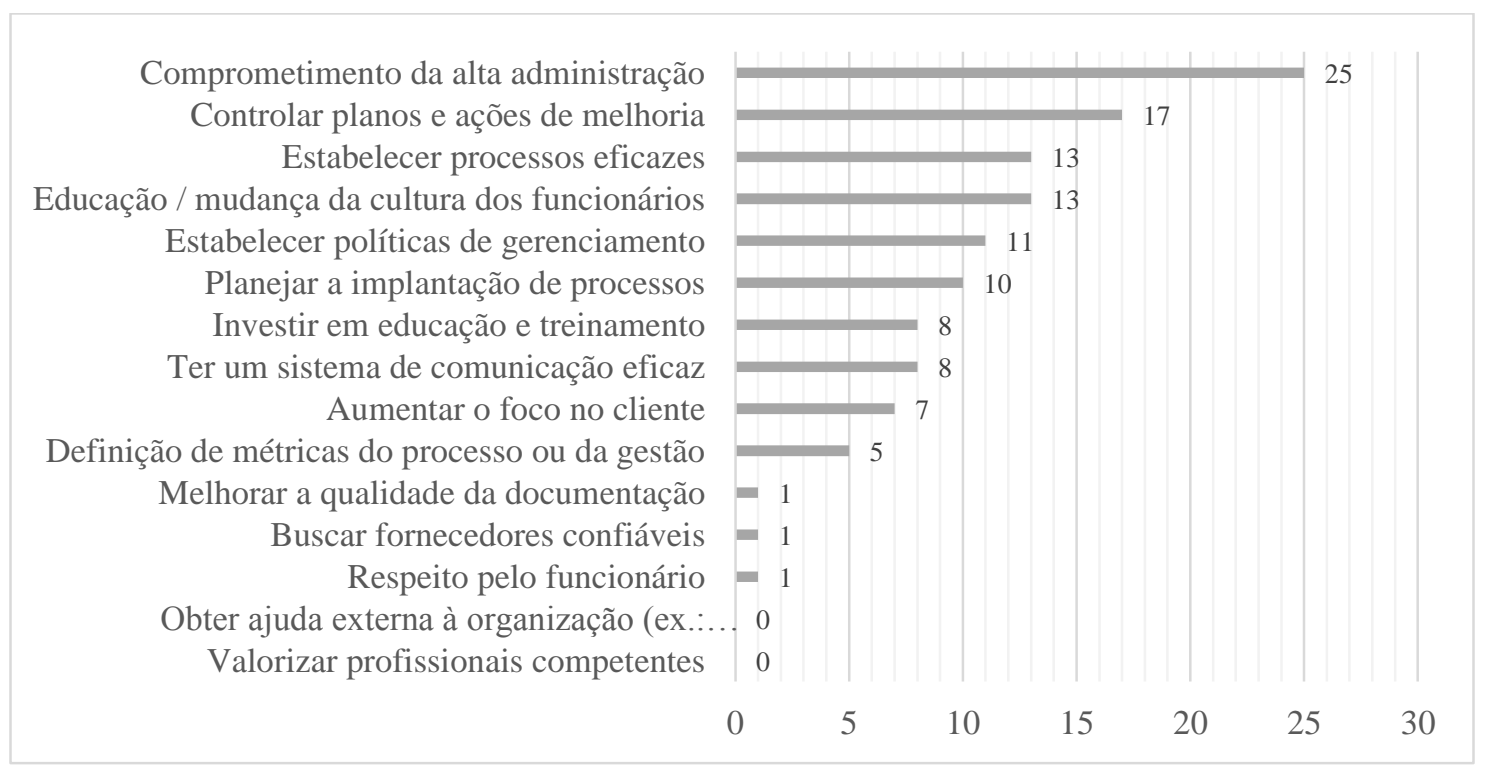

Figura 24 - Dificuldades enfrentadas para adotar e manter o sistema de governança de TI em conformidade à norma ISO 20.000 (Q14).

O comprometimento da alta administração foi o principal fator apontado na pesquisa. A cultura de melhoria contínua aparece em segundo lugar, bem como a mudança necessária em quarto, pois é difícil adotar práticas com disciplina necessária para estabelecer e, principalmente, manter controles que ajudem a verificar o desempenho da organização e dos serviços. Os 
processos são o meio através do qual estas práticas passam a fazer parte dos requisitos impostos pela organização.

Sobre desempenho da organização, as questões 12 e 13 foram propostas de modo a validar as opiniões dos respondentes, eliminando-se assim vieses de respostas inconsistentes por falta de atenção ou pela ordenação de fatores (FISHBEIN; AJZEN, 2010). As respostas são apresentadas nas duas figuras abaixo.

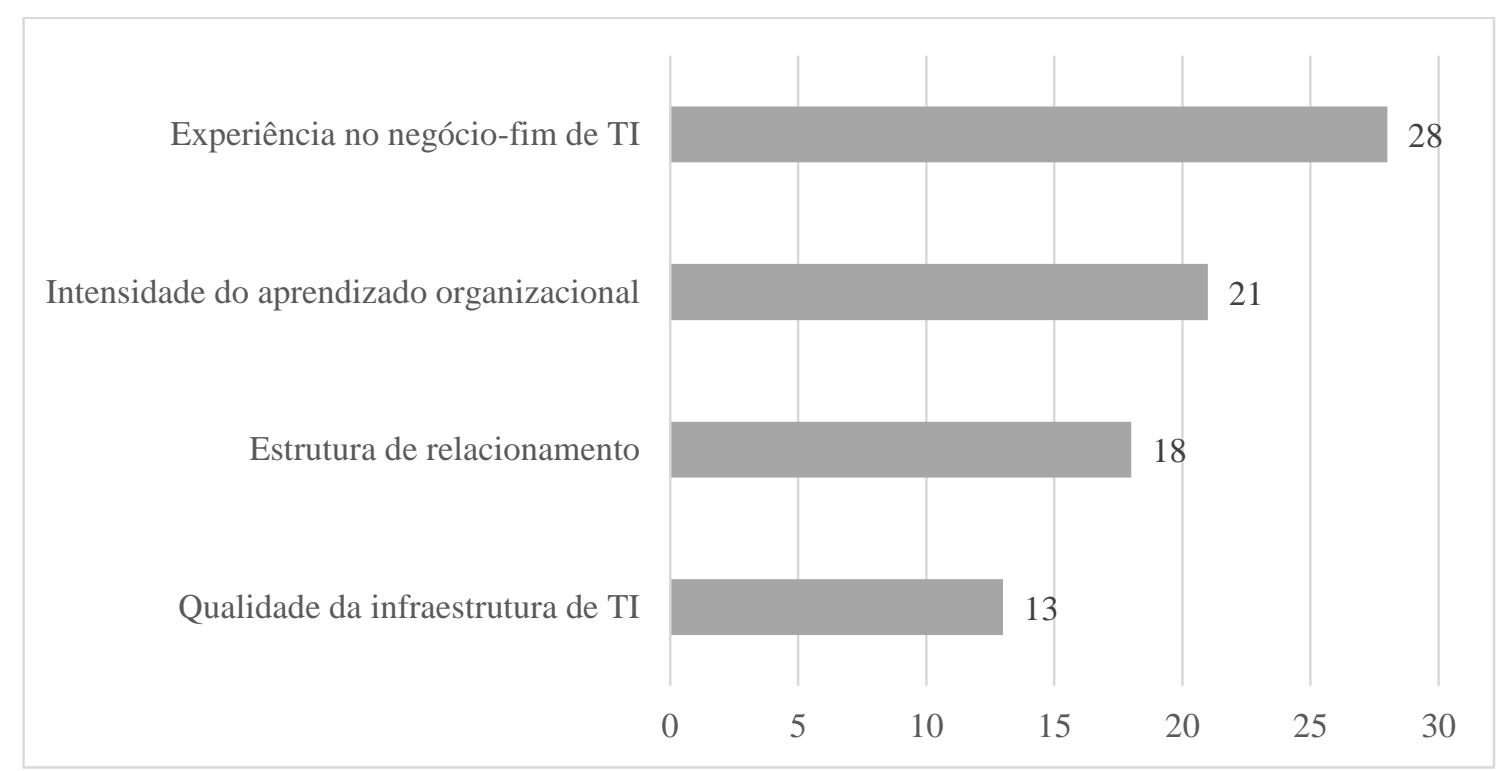

Figura 25 - Benefícios alcançados com a adoção da norma ISO 20.000 (Q12).

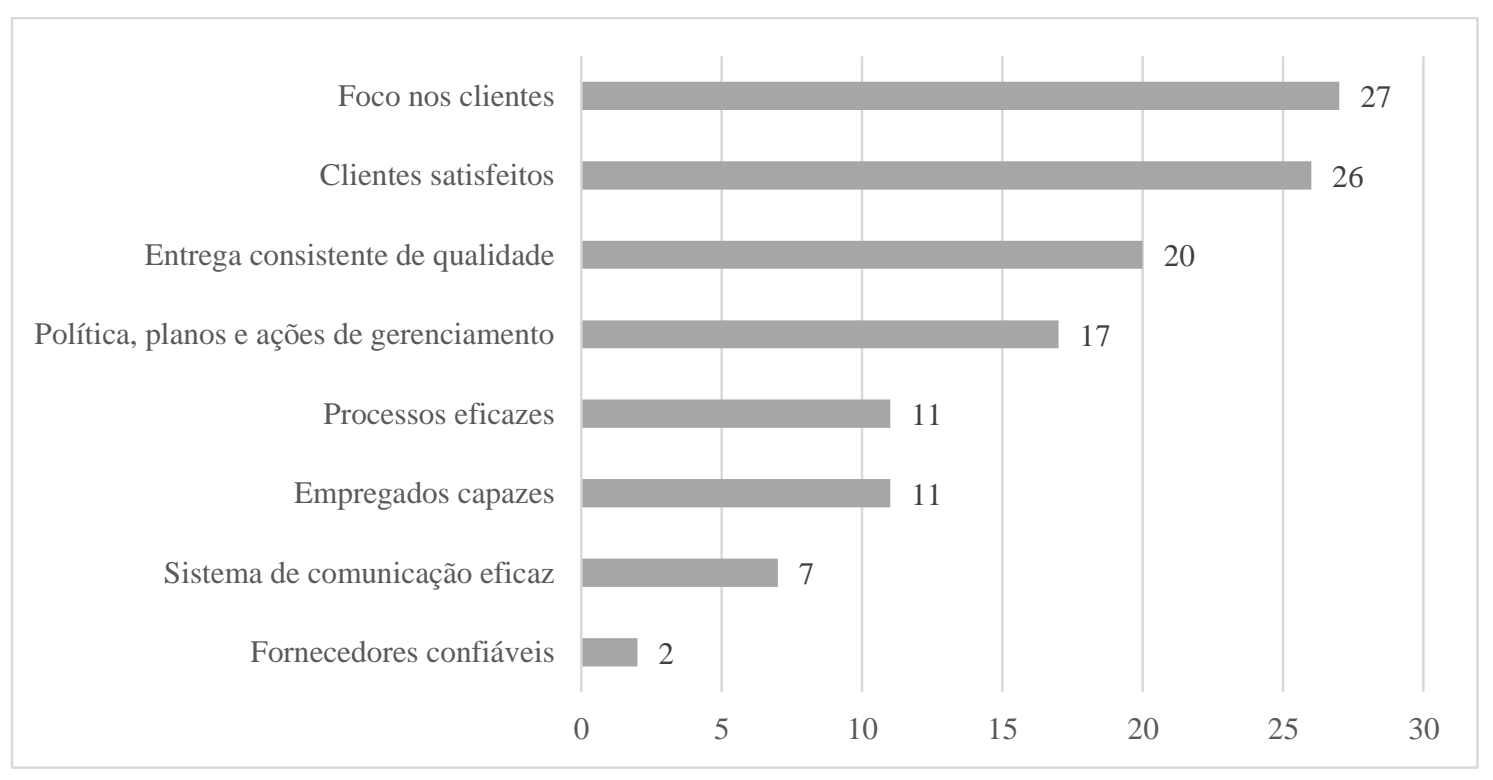

Figura 26 - Fatores de desempenho alcançados ao adotar da norma ISO 20.000 (Q13). 
O principal ganho apontado foi melhoria na experiência no negócio-fim, uma vez que se entendeu o desempenho como foco nos requisitos e necessidades dos clientes, para ganhar contratos e para mantê-los satisfeitos. O aprendizado organizacional representa a mudança por parte dos profissionais ao adotar uma cultura de melhoria contínua, através da aplicação constante de comunicação e processos eficazes.

Em ordem de maior porcentagem do escore, as respostas mais significativas das questões $12 \mathrm{e}$ 13, ao utilizar a análise de Pareto (HAIR JR. et al., 2009) foram as seguintes:

- Benefícios (Q12): experiência no negócio-fim (A); intensidade do aprendizado organizacional (B);

- Desemepenho (Q13): foco nos clientes (A); clientes satisfeitos (A); entrega consistente de qualidade (C); políticas, planos e ações de gerenciamento (C).

Agruparam-se os fatores em: foco nos clientes (A), pessoas (B) e processos (C). Ao verificar os que mais aparecem depois desta análise, vê-se que prepondera a necessidade de foco nas necessidades dos clientes, para gerenciar adequadamente as expectativas sobre os serviços ao longo da vigência dos contratos.

\subsection{Pessoas}

Os quatro fatores apresentados na Figura 4 - visibilidade das ações, controle, reflexão em práticas e conformidade a regras - foram levantados a partir de perguntas colocadas de maneira a obter respostas em uma escala de classificação, com cinco valores possíveis, de acordo com o julgamento de valor do respondente. As respostas são representadas em gráficos nesta seção sendo que o valor mais à direita corresponde a maior maturidade de processos como prescrito no modelo canônico de governança de TI (Seção 3.10) e Cobit (Seção 3.6), e quanto mais à esquerda, menor maturidade.

A visibilidade das ações foi avaliada através de quanto a organização busca ser gerenciada através de métricas formalizadas e como é feita a comunicação da liderança. $63 \%$ dos entrevistados concordaram totalmente e os restantes $38 \%$ concordaram que os processos de 
governança de TI foram comunicados (Q21). Já quando perguntados sobre os registros formais das atividades, há uma dispersão maior nas respostas, como apresentado na Figura 27.

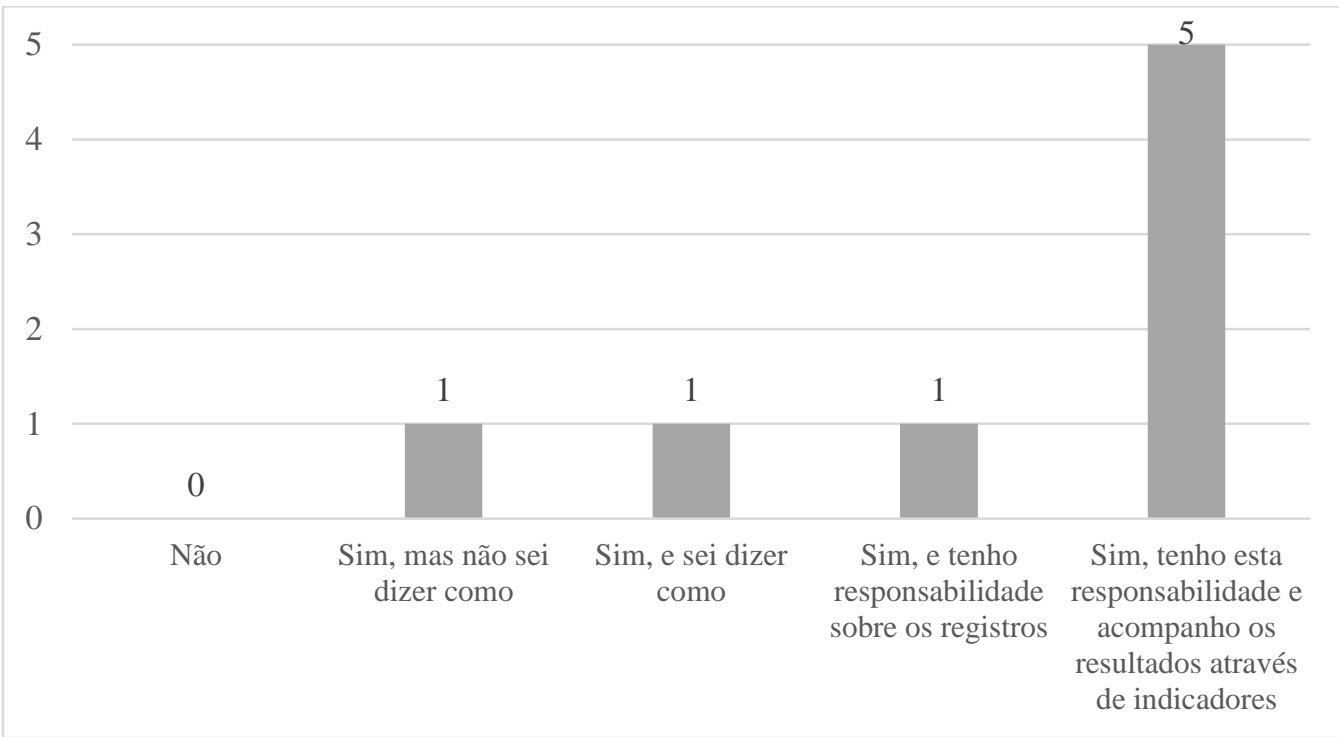

Figura 27 - Respostas sobre os registros formais das atividades (Q22).

O controle é relacionado a como os níveis de liderança acompanham os resultados, conforme Figura 28.

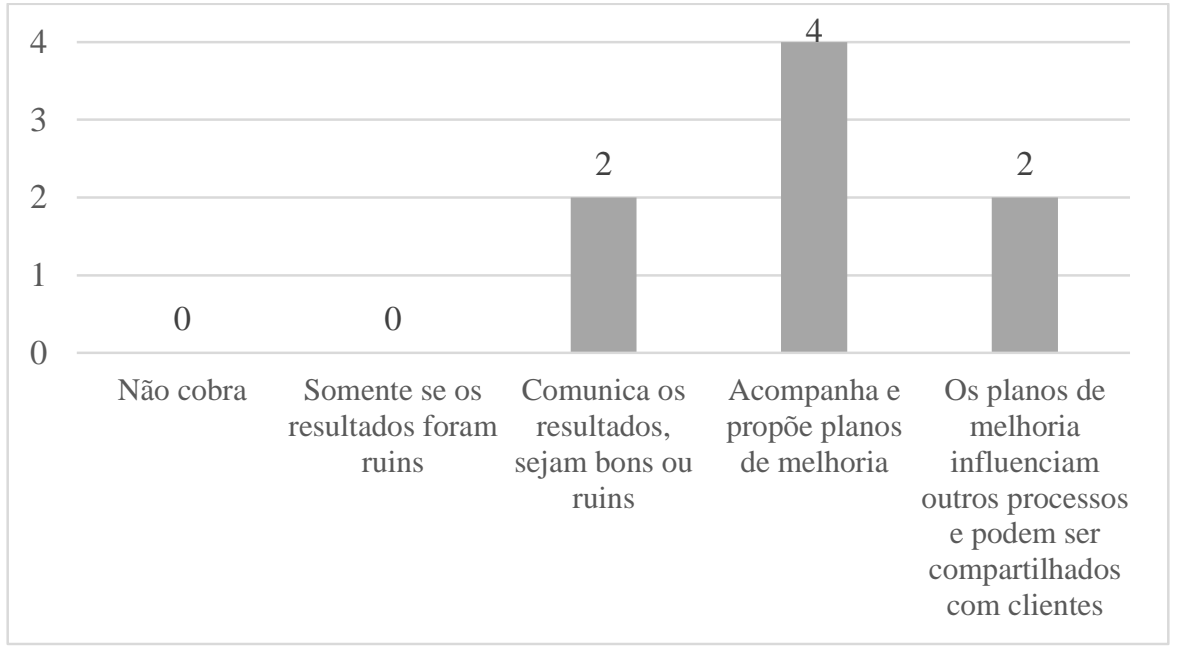

Figura 28 - Acompanhamento de resultados pelo chefe imediato (Q23).

Questionou-se quanto à atitude do chefe imediato para se estabelecer uma relação de quanto controle coercitivo pode ser exercido pela liderança da organização. Nestas questões, vê-se não a maturidade do processo na escala, mas sim sua força coercitiva de quanto as regras prescritas pela organização devem ser seguidas. Buscou-se entender sua atitude em situações ante o 
negócio e no dia-a-dia com os profissionais de sua área. Quanto mais à esquerda na escala das respostas apresentada na Figura 29, maior autonomia o líder dá a seus comandados.

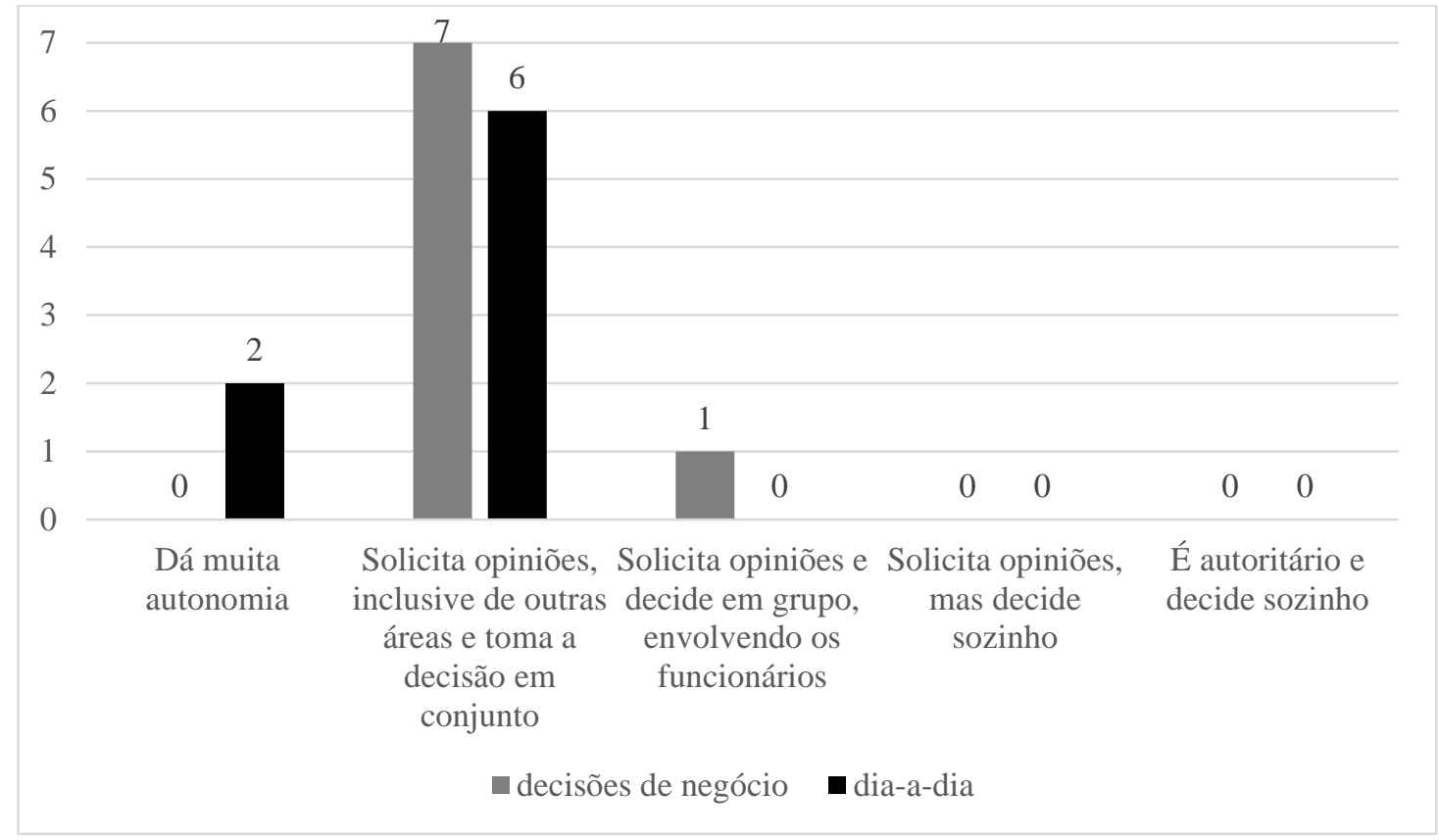

Figura 29 - Atitudes do chefe imediato em situações de decisão de negócio e no dia-a-dia (Q24 e Q25).

Nota-se uma abertura da liderança ao dar autonomia aos profissionais conforme Figura 29. Em organizações que fomentam a melhoria contínua esta condição é fundamental para permitir a evolução das práticas da organização.

A conformidade aos requisitos mostra o quanto o indivíduo conhece e segue os processos prescritos pela organização. Confirmando o que havia sido mostrado na Figura 27, nem todos os profissionais têm visibilidade ou entendimento completo de como os processos de governança de TI são diretamente aplicáveis a suas atividades de dia-a-dia. Pode-se ver esta relação na comparação das respostas às questões Q26 e Q28, consolidadas na Figura 30. 


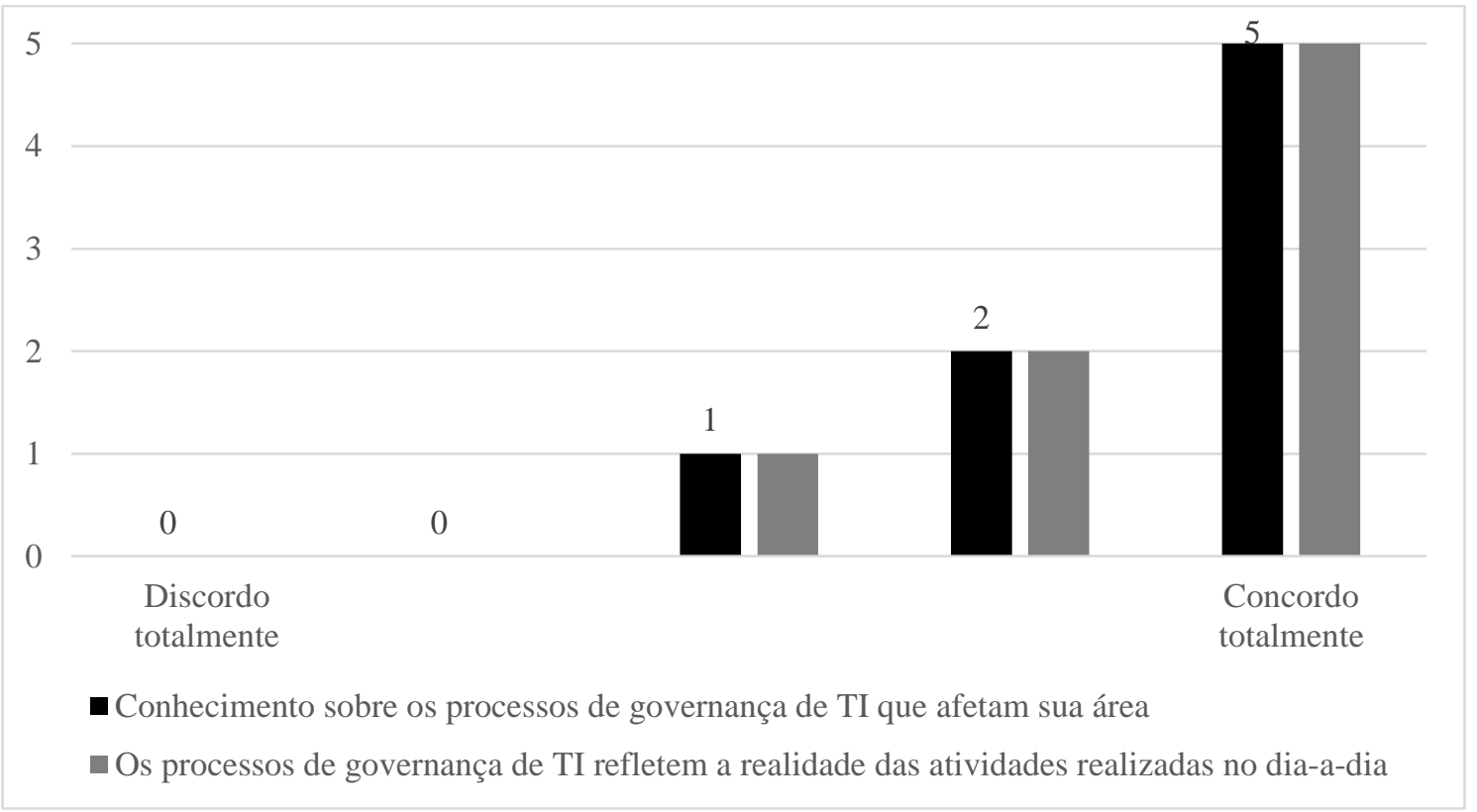

Figura 30 - Relação entre profissionais terem conhecimento sobre os processos de governança de TI e entenderem se refletem a realidade de suas atividades no dia-a-dia (Q26 e Q28).

A participação na elaboração dos processos mostra o comprometimento da liderança na utilização das práticas de gerenciamento, como ilustrado na Figura 31.

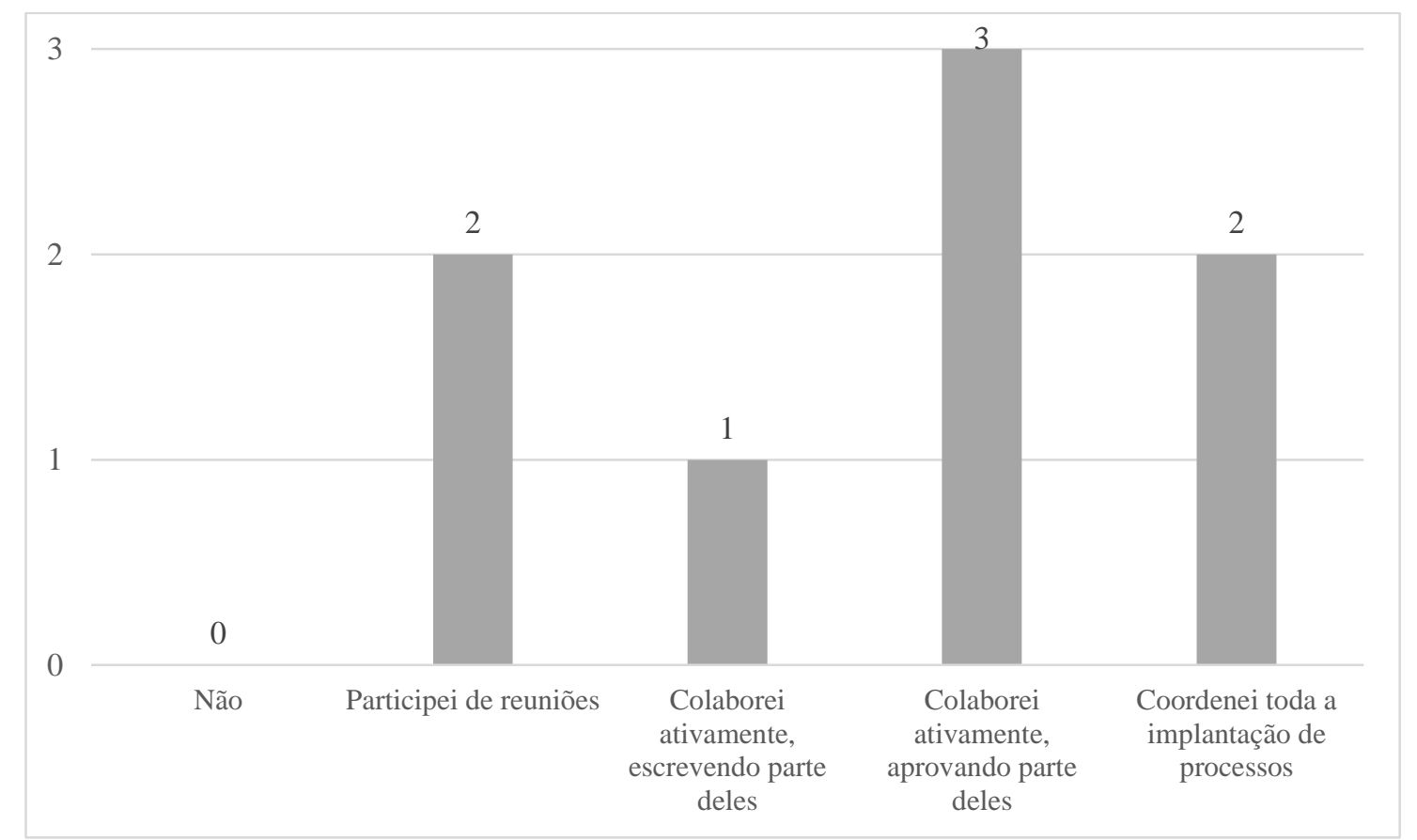

Figura 31 - Participação do profissional na definição dos processos de governança de TI (Q27). 
A reflexão em práticas mostra o quanto o indivíduo participa de maneira proativa de como os processos são documentados e revisados. A Figura 32 mostra as respostas em que os respondentes afirmar ter proposto mudanças a processos documentados da organização e o quanto os seguem documentados.

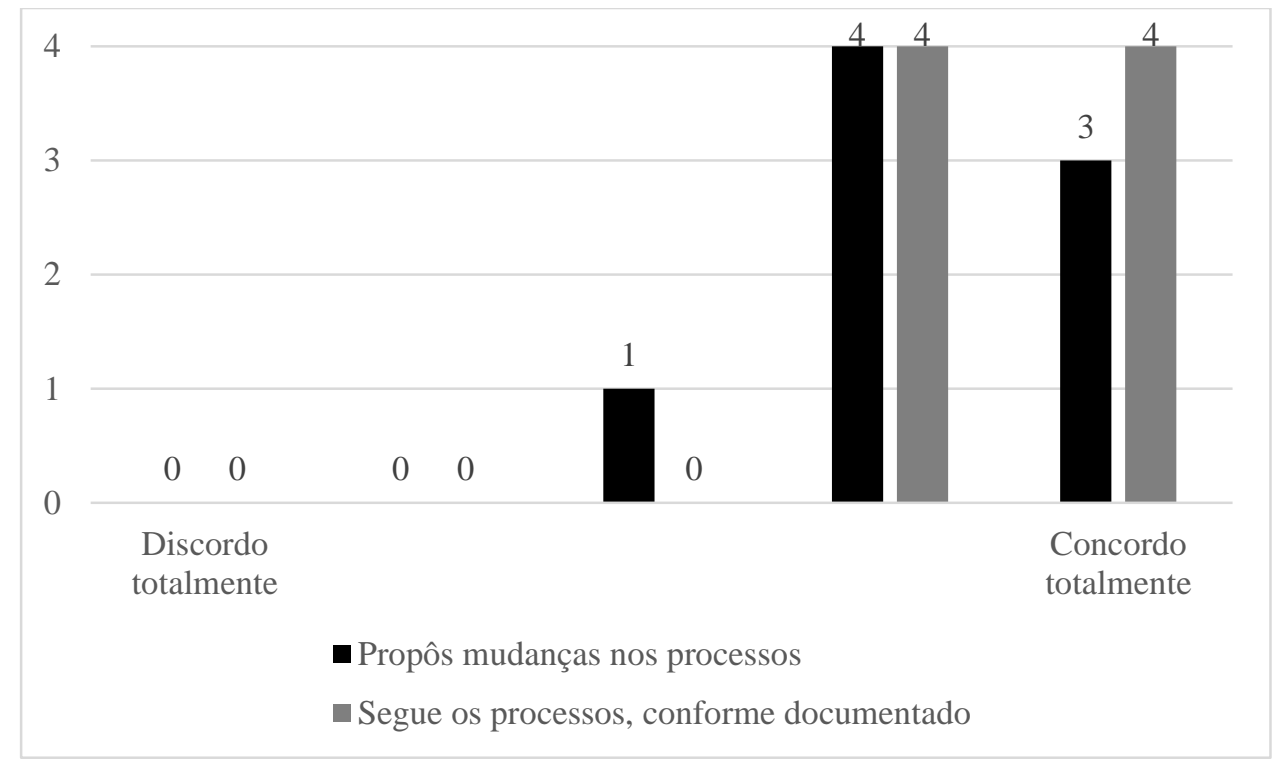

Figura 32 - Reflexão em práticas: relação entre os profissionais seguindo os processos documentados e propondo mudanças aos mesmos (Q29 e Q30).

Estes resultados mostram a presença bem estabelecida das práticas de melhoria contínua, em que os profissionais buscam refletir sobre as atividades buscando propor mudanças quando necessário.

A maior parte dos entrevistados (63\%) concordou totalmente e o restante (38\%) concordou que os processos de governança de TI foram implantados e são mantidos com apoio da alta liderança (Q31). Isto está de acordo com o que foi verificado na Figura 24: a participação da alta liderança na implantação e manutenção do sistema de governança de TI é fundamental. Por outro lado, reflete a prescrição de práticas da organização que impacta diretamente os profissionais sobre a visibilidade e conformidade a regras impostas para as atividades da operação. 


\section{COLETA DE DADOS: FASE 2 - ENTREVISTAS}

São apresentados os dados coletados durante as entrevistas com representantes das organizações que responderam ao questionário da primeira fase. Das oito entrevistas realizadas, cinco foram realizadas pessoalmente e três, via internet utilizando a ferramenta Skype.

As entrevistas tiveram duração média de setenta minutos, durante as quais o pesquisador tomava notas livres e também pautadas nas respostas estruturadas do roteiro de entrevista.

\subsection{Empresa 1}

\subsubsection{Qualificação}

- Origem: brasileira;

- $\quad$ Ano da obtenção da certificação ISO 20.000: 2012;

- Número de profissionais: mais de 2.500;

- Cargo dos entrevistados: Head of IT Governance (7 meses no cargo); Analista de sistemas (18 meses no cargo);

- Atitude da organização perante o risco: conservadora (Q18: "reduz/mitiga os riscos");

- Período da coleta de dados: maio a julho/2014.

- Como é o processo de decisão sobre investimentos em TI (Q4): através de avaliações do board e da alta direção (R6). Os investimentos em TI são decididos em comitês executivos, com a participação de vice-presidentes e diretores, que recebem informações das gerências de acordo com seu desempenho e necessidades. Este comitê leva as informações ao presidente para as decisões finais (D12, R1).

- Investimento em certificações, treinamentos, consultorias e atividades internas específicas para a certificação ISO 20.000 (Q5): R \$ 250 mil por ano, sendo treinamentos constantes para manter a cultura de processos e evitar erros na operação (D8).

- Quais outros modelos de referência de práticas de governança de TI sua organização adota (Q6): Cobit, ITIL, PMBoK, BSC, CMMI e Seis Sigma. Sendo os dois primeiros destacados para levar as métricas de governança e operacionais para a alta direção da organização e promover os planos de ação de melhoria (D13). 
- A empresa investiu em certificação para os profissionais nestes modelos de referência (Q7): sim.

- Com relação à estratégia de implantação da norma (Q8): a pergunta não havia sido respondida através do questionário da primeira fase, mas se verificou na entrevista que a organização já possuía os processos, que foram adaptados aos requisitos da norma ISO 20.000. As demandas de mercado por segurança e governança corporativa acabaram gerando a necessidade da certificação (R3).

Empresa 1 é brasileira, cujas operações se iniciaram no final da década de 1990 sempre com foco em terceirização de serviços de TI. Ao longo dos anos houve aportes de fundos de investimento brasileiros e a abertura de escritórios em diferentes partes do país para ampliar sua capilaridade e proximidade aos clientes. Atualmente conta com um crescimento em seus negócios da ordem de $15 \%$ ano sobre ano.

A organização possui profundo conhecimento no atendimento do segmento financeiro do mercado, tendo neste a maior parte do faturamento proveniente de seus clientes. Considera como seus diferenciais: agilidade e flexibilidade nos negócios, e especialista em operações complexas de larga escala e alta disponibilidade.

Seu portfólio de serviços compreende a terceirização de processos de negócio, de serviços de TI e data center, desde a infraestrutura como colocation e hosting, até a operação completa das atividades.

\subsubsection{Resumo do caso}

Dos fatores relacionados a desempenho, o que mais recebeu foco durante a entrevista foi satisfação dos clientes (D2). Através de medições periódicas, regidas por processos internos, são entregues relatórios diretamente aos clientes com análise crítica da equipe de gerência de serviços e acompanhamento dos planos de ação (D10).

Como diferenciais em relação ao mercado para atingir esta satisfação, foram apontados os processos e conhecimento dos profissionais (D4). A presença de um executivo de conta que relata os indicadores contratuais e de satisfação do cliente e acompanha os planos de ação para 
melhoria foi destacada (D5). A arquitetura de TI acaba não sendo destacada por ser o negóciofim da empresa. O portfólio de serviços de TI ser adequado aos concorrentes do mercado (D3). Portanto a adaptação constante da organização e de seus profissionais relacionada à evolução da tecnologia é considerada primordial.

Para o início dos contratos, a organização conta com uma área de transição que é responsável pode definir a melhor maneira de adequação dos processos do cliente para os da organização (D7). Desta maneira se busca minimizar os impactos negativos à operação do cliente e para que a organização prestadora de serviços de TI tenha tempo de aprender as particularidades do negócio e dos serviços do cliente (D6). Com relação à estrutura de TI atual dos clientes, a organização define os ambientes críticos de negócio, para entender quais são os serviços e elementos de infraestrutura fundamentais para a manutenção da disponibilidade da TI do cliente (D14).

Relatórios de métricas das áreas acompanhados pela alta administração (D11). Estas métricas permitem visibilidade à execução dos processos com sua ligação direta ao desempenho do cliente. Foi citada a utilização de Cobit para determinar métricas mais voltadas à alta direção, e ITIL para métricas operacionais de gestão dentro das áreas (R9). Estas medições são feitas por uma área de qualidade independente (gerência de serviços), de modo a garantir adequadas coleta e análise de dados. Uma estrutura considerada sustentável por uma organização do porte desta estudada, uma vez que para organizações menores estes custos poderiam ser considerados overhead excessivo.

Com relação a fornecedores e parceiros de negócios (D1), estes não foram considerados como diferenciais para os negócios, uma vez que as entregas de serviços contratados pelo cliente são de responsabilidade da organização, sendo que as capacitações, profissionais e tecnologias necessários para sua entrega devem estar no núcleo da empresa, e não terceirizado.

Com relação a riscos, nota-se que a organização é cautelosa quanto a riscos de negócio, tendendo a buscar o máximo uso de sua padronização de processos e ferramentas para ganho de escala e manutenção de sua consistência (R7). Possui estratégia e plano de recuperação de desastres, e tornou este processo em um elementode sua oferta sendo que $70 \%$ de seus clientes compram estes serviços (R4). Nota-se uma coerência entre a atitude perante a riscos desta organização e dos clientes que a procuram. 
Sobre o impacto sobre os investimentos de TI (R2), nota-se uma clara tendência dos clientes de terceirização de serviços de TI de transferir os riscos de sua operação. Como os clientes, em geral, não trabalham internamente seus processos para deixar clara a mudança para seus gestores e usuários para um modelo em que haverá um prestador de serviços, os investimentos deste acabam sofrendo modificações para a entrega dos requisitos do contrato (R10, D12). Sem as expectativas claras dos usuários e gestores sobre os níveis de serviço contratados, o incremento de chamados com urgência e customizações é significativo, elevando os custos do prestador de serviço.

As decisões sobre os investimentos em TI são tomadas na esfera corporativa (R1), sendo que as necessidades de cada operação são consolidadas pelos respectivos gerentes e diretores e posteriormente levados à aprovação pelo board. Há também investimentos necessários pelo consumo da infraestrutura atual e sua atualização, que são discutidos da mesma forma, mas com processo de aprovação diferente, dada a prioridade de manter os contratos atuais funcionando adequadamente (R11).

Sobre segurança da informação (R5), os fatores apontados como mais preocupantes são o reforço de controles de acesso evitando perdas de informação interna, bem como as regulamentações vindas da governança corporativa, e externamente à organização as indisponibilidades da rede elétrica e a regulamentação PCI (específica para empresas que utilizam transações financeiras através de cartão de crédito). O ciclo de vida do login identificação do usuário - foi apontado como ponto necessário a ser coberto pelos processos de segurança, uma vez que envolvem diferentes áreas, como recursos humanos, área do profissional, TI, etc. podendo deixar aberta alguma vulnerabilidade de acesso a dados ou sistemas da organização, mesmo quando o profissional seja desligado.

O constante investimento em treinamentos para os profissionais reforça a cultura voltada a processos e métricas. O principal objetivo da organização é diminuir erros operacionais (R6), apontados como um dos principais riscos, uma vez que a taxa de turn over (saída de profissionais que motiva contratações de reposição) em alguns setores fica na média de mercado - como na central de serviços com taxa de $30 \%$ ao ano. Mesmo em uma organização bastante voltada a processos, a preocupação volta-se ao indivíduo, pois "é quem, ao final, executa as tarefas". Os treinamentos são constantes, inclusive fora do horário de trabalho dos profissionais 
para não prejudicar as equipes em operação, para manter a cultura de processos, embora isto seja um elemento a mais de estresse para os profissionais, em detrimento a sua vida pessoal (D8, D9).

Uma contradição encontrada é a importância teórica dada ao processo de gerenciamento de configuração (R8). Sua função é controlar e manter os ativos de TI que permitem a prestação de serviços pela organização. Porém a percepção de valor entregue para o cliente por este processo é baixa. É muito custoso para ser mantido, com baixo benefício.

\subsubsection{Pontos mais relevantes do caso}

Como destaque, a utilização de indicadores associados aos processos de governança de TI fornece visibilidade à alta direção do desempenho das diferentes áreas e profissionais. Para os profissionais, estes indicadores e metas dão a adequada ideia do por que devem executar suas tarefas conforme os processos estabelecidos. Entre os gestores de área, geram a busca pela conformidade pelo questionamento da alta direção e a comparação direta de seu desempenho entre seus pares. Portanto, estabelecer poucos e eficazes indicadores apresentou resultados relacionados à satisfação dos clientes, o que permite um processo de tomada de decisão mais objetivo e baseado em dados.

\subsection{Empresa 2}

\subsubsection{Qualificação}

- Origem: brasileira;

- Ano da obtenção da certificação ISO 20.000: 2011;

- Número de profissionais: 350 (de 100 a 1.000);

- Cargo do entrevistado: Diretor de TI (4 anos no cargo);

- Atitude da organização perante o risco: propensa a riscos (Q18: “aceita os riscos”);

- Período da coleta de dados: junho a julho/2014.

- Como é o processo de decisão sobre investimentos em TI (Q4): gestores da empresa. Por ter um modelo de governança corporativa familiar, as decisões passam diretamente pelos 
sócios da organização. As decisões são muito focadas na realização de vendas: se as metas são cumpridas e novos contratos são firmados, há dinheiro destinado a melhorias na infraestrutura de TI (D12).

- Investimento em certificações, treinamentos, consultorias e atividades internas específicas para a certificação ISO 20.000 (Q5): R \$ 80.000,00 / ano.

- Quais outros modelos de referência de práticas de governança de TI sua organização adota (Q6): a importância da certificação é bastante voltada à melhoria contínua dos processos operacionais (D13). Porém, é complexo traduzir esses benefícios para a força de vendas da organização.

- A empresa investiu em certificação para os profissionais nestes modelos de referência (Q7): sim.

- Com relação à estratégia de implantação da norma (Q8): a organização já possuía os processos, que foram adaptados aos requisitos da norma (R8). A norma foi adotada para auxiliar na manutenção das atividades, aumentando sua eficiência e permitir o crescimento. O fator principal de decisão é credenciar a organização a participar de short lists de concorrências (D13).

Empresa 2 é brasileira, cujas operações se iniciaram na década de 1980. Primeiramente atuava como revenda de produtos de tecnologia de informação, mas com o crescimento deste mercado no Brasil, reformulou seu portfólio e posicionamento de mercado, atuando como integradora de serviços e soluções de TI através de soluções customizadas a seus clientes.

Em seu portfólio constam serviços de gestão de ativos, data center (movimentação, venda, instalação e configuração de equipamento) e operação $24 \times 7$ através de serviços gerenciados, central de serviços e projetos de infraestrutura de TI que atingem as diferentes camadas desde o projeto elétrico básico a telefonia IP e telepresença.

\subsubsection{Resumo do caso}

A empresa 2 possui um modelo de governança corporativa familiar, sendo que há um sócio majoritário da organização desde sua fundação. Com este contexto, entende-se como sucesso e desempenho dos negócios o volume de vendas e a margem de contribuição de cada projeto em andamento (D2). O foco das operações é dado sobre os serviços prestados aos clientes, sendo 
medido através de pesquisas de satisfação. Estas informações são levadas diretamente ao sócio majoritário da empresa para reavaliação e possíveis ações (D6).

Para atender às demandas de mercado, o portfólio de serviços da organização é voltado aos processos de negócio dos clientes (D3). Cada vez mais a organização passa de uma venda estritamente técnica para uma abordagem consultiva sobre qual o problema a ser resolvido para o cliente. Como fator diferencial neste atendimento, foram citados os processos da organização (D4). Ao se questionar com um pouco mais de ênfase sobre os reais diferenciais da certificação ISO 20.000, o conhecimento dos profissionais acabou sendo destacado também: de nada adianta ter os processos documentados se os profissionais não os utilizam (D13).

Neste aspecto, foram citados os treinamentos internos e campanhas de documentação dos processos e procedimentos operacionais (D8, D9). Estes documentos são utilizados durante a fase da pré-venda para mostrar maturidade aos possíveis clientes. Como exemplo foi citada a área de Service Desk (central de serviços), que precisa de procedimentos bastante claros para funcionar de maneira eficiente. Desta forma se busca minimizar os riscos operacionais por falhas dos profissionais, com uma comunicação rápida das mudanças promovidas nas atividades por cliente (R10).

Seguindo o modelo de governança familiar, as priorizações de negociações e recursos para TI são decididas diretamente pelos sócios (D5, D14, R1). A cadeia de valor interna imposta aos contratos e operações da organização é bastante clara: o volume de vendas dita a disposição de recursos (D11). Não há evidências de orçamentos separados por áreas ou para atividades específicas, como reinvestimentos ou treinamentos, sendo que estas atividades ocorrem caso haja volume de vendas suficiente para trazer recursos que, tendo sido tratados os requisitos dos clientes, são aplicados em tais fins (D8, D14). As práticas de governança de TI são diretamente determinadas pela governança corporativa através do sócio majoritário (R11).

A participação de parceiros de negócio não foi vista como diferencial para o cumprimento de requisitos dos clientes, sendo considerada sua contratação como responsabilidade da área de suprimentos (D1). Destacou-se na entrevista que o nível de exigência dos clientes para a organização não é repassado por esta a seus fornecedores: motivado pelos altos custos que auditorias constantes trariam e mesmo por ser considerado algo secundário. 
Nesta organização, os riscos dos serviços de TI prestados ao negócio do cliente são entendidos por diferentes perspectivas: queda no faturamento, problemas de pagamento ou recebimento, paradas na operação e reputação da empresa perante o mercado - sendo este último considerado um prejuízo intangível (R2). Para a continuidade de negócios, somente há plano de recuperação de desastres (R4).

A atitude da organização perante o risco é bastante definida: propensa a riscos, para busca de alto retorno (R7), diretamente relacionada ao apetite por desempenho do sócio majoritário. Em termos da relação apresentada na Figura 1, para um alto desempenho se admite um grande risco. Por exemplo, foram citados novos contratos de clientes nos últimos cinco anos em que não havia capacitação interna da equipe para realizá-los. Para atender aos requisitos de um novo cliente, a organização está disposta a aceitar o risco da falta de conhecimento interno e contrata profissionais diretamente no mercado, para ter o aporte adequado de conhecimento (D7), uma vez que não haveria tempo de treinar os profissionais presentes na organização.

Caso detectado em suas medições de desempenho, falha de um projeto que começa a apresentar prejuízo, é feito um estudo baseado em procedimento e método formalizado na organização, com relação a sua situação de momento até o final do contrato (R9). Caso não haja reequilíbrio possível, recomenda-se e se efetiva a descontinuação do contrato.

Estas medições, bem como a satisfação dos clientes, são feitas por uma área interna de qualidade, independente das áreas operacionais (D7). Os resultados são apresentados aos clientes por seus respectivos gestores, sendo avaliados para possíveis ações de melhoria (D10). As métricas se dividem em categorias: vendas (volume), projetos (desempenho pelas disciplinas do PMBoK), operações (com poucos indicadores, mas relacionados a ITIL) e back office (para desempenho das áreas de apoio ao negócio e controle de seus custos).

Sobre segurança da informação, foi destacado o comportamento dos clientes de transferir os riscos da operação de uma maneira pouco controlada (R2, R3): em que se deposita no prestador de serviços de TI a responsabilidade pela operação adequada dos serviços que suportam seu negócio. Do ponto de vista interno, os erros operacionais (R6) e roubo de informações aparecem como fatores de destaque, sendo controlados e mitigados através de treinamentos e auditorias (R5). Apesar da análise de riscos, medidas preventivas e processos de gerenciamento, o fator 
operacional, responsabilizando as pessoas pela execução inadequada de atividades, aparece como destaque das preocupações do gestor.

Em particular, o processo de gerenciamento de configuração foi apontado como pouco maduro, uma vez que é custoso de ser implantado e principalmente para ser mantido. O controle de ativos é feito somente par aos casos em que o cliente o adquire como serviço (R8). Uma contradição aparece uma vez que oferecem este controle com processo e ferramenta a clientes, mas não realizam tais atividades internamente.

\subsubsection{Pontos mais relevantes do caso}

A propensão a riscos faz com que a organização busque um desempenho mais acentuado, uma vez que disputa espaço no mercado com empresas maiores e de marca mais consolidada. Os processos são colocados como diferenciais para a organização, mas a dependência do conhecimento dos profissionais para a tomada de novos contratos é latente. O contraexemplo é a área de Service Desk, que conseguiu crescer de modo centralizado, apresentando ganho de escala e rentabilidade, por ser mais fortemente apoiada em seus processos internos.

Por possuir o modelo de governança corporativo familiar, muitas decisões são centralizadas no sócio majoritário. A estratégia de não crescer muito em número de funcionários minimiza o risco da perda de controle dos processos pelo crescimento e se adequa ao modelo centralizado de tomada de decisões.

\subsubsection{Outros comentários dos entrevistados}

A compra de serviços de TI pelos clientes foi destacada como um fator a ser amplamente estudado e melhorado. Os critérios para seleção e as negociações durante as pesquisas de preço não tratam com a devida atenção as expectativas sobre o escopo das atividades a serem executadas durante a vigência do contrato. Acaba-se dispendendo muito esforço e tempo tanto do cliente quanto do provedor de serviços para, durante a vigência do contrato, acertar pontos que não são discutidos durante a pré-venda. 


\subsection{Empresa 3}

\subsubsection{Qualificação}

- Origem: norte-americana;

- Ano da obtenção da certificação ISO 20.000: 2012;

- Número de profissionais: mais de 2.500;

- Cargo dos entrevistados: Diretor de TI (2 anos e 9 meses no cargo);

- Atitude da organização perante o risco: conservadora (Q18: "reduz/mitiga os riscos”);

- Período da coleta de dados: maio a julho/2014.

- Como é o processo de decisão sobre investimentos em TI(Q4): a estrutura de gerenciamento dos clientes é composta de gestores e executivos, que têm autonomia para verificar os resultados de suas operações e necessidades junto aos clientes (D12). A partir destas, trazem a demanda de investimentos para a organização, que são aprovadas pelo board (D2, D7).

- Investimento em certificações, treinamentos, consultorias e atividades internas específicas para a certificação ISO 20.000 (Q5): os treinamentos são continuados, com o objetivo de manter o conhecimento dentro da organização, através de seus processos (D8).

- Quais outros modelos de referência de práticas de governança de TI sua organização adota (Q6): Cobit, ITIL, PMBoK, BSC, CMMI e Seis Sigma. A ênfase sempre é dada aos processos desenvolvidos internamente (D13).

- A empresa investiu em certificação para os profissionais nestes modelos de referência (Q7): sim.

- Com relação à estratégia de implantação da norma (Q8): a organização já possuía os processos, que foram adaptados aos requisitos da norma.

Empresa 3 é resultado de uma aquisição na segunda metade da década de 2000, cuja divisão de serviços operava desde a década de 1960. Uma organização global que atua em 60 países, compartilhando o mesmo conjunto de alianças tecnológicas e de processos de gerenciamento de serviços de TI.

Seu portfólio de serviços conta com a terceirização da tecnologia de infraestrutura (ITO Infrastructure Technology Outsourcing), aplicações (desenvolvimento, integração e atualização de software) e terceirização de processos de negócio (BPO - Business Process Outsourcing). 


\subsubsection{Resumo do caso}

Na visão do gestor, o desempenho pode ser resumido pela qualidade percebida pelos clientes nos serviços prestados (D2). A satisfação dos clientes, está sendo uma consequência da entrega consistente de qualidade somada a empregados capazes (Q13). Os resultados são medidos em relação aos requisitos dos clientes (D10). Através desta visibilidade são estabelecidos planos para análise de causa raiz e melhoria. O importante é que a atuação é cobrada não somente em momentos que os objetivos não são atingidos, mas também quando se pode comparar com outras áreas internas e promover troca de melhores práticas (D5, D6).

A governança corporativa faz com que as áreas interajam de modo a atender aos requisitos dos clientes (D6), fazendo com que as decisões de investimento sejam aprovadas nas instâncias dos executivos das contas com participação do board (R11). Cada área tem o controle sobre seus orçamentos e planos de investimento, que são acompanhados durante o exercício do ano físcal (D5).

Para manter o desempenho junto aos clientes, é preciso comunicar às equipes seus objetivos e respectivos resultados de modo constante. O profissional deve estar sempre ciente destes indicadores, mantendo o espírito de melhoria contínua, buscando a melhoria contínua através de sua comparação com áreas similares (D8). Processo este facilitado pela transparência na divulgação de resultados e acesso a dados nas ferramentas. Os líderes incentivam constantemente as conversas entre áreas para entender como se pode melhorar (D11). As revisões são feitas dentro de cada área, posteriormente com cada gerência e com cada diretoria, levando a decisões sobre melhorias e investimentos em cada operação ou para a manutenção e crescimento da infraestrutura atual que mantém os contratos em adequado funcionamento (D14). Estes indicadores são tratados também com os clientes, para verificar o desempenho específico da conta e percepções do cliente (R9).

Para o desenvolvimento dos profissionais, a organização investe em treinamentos constantes, cujo programa é definido em conjunto com os gestores, tanto em processos, quanto em ferramentas (D8). Há plano de carreira individualizado, avaliações 360 graus (em que o profissional é avaliado por seus pares, subordinados e chefia) e feedback constante. Novamente o uso de métricas torna o processo mais objetivo, relacionando o desempenho individual aos da 
área e da organização. Não foi dado destaque à participação de terceiros, uma vez que a organização busca prestar os serviços diretamente com mão-de-obra própria (D1).

A visão da organização perante riscos é conservadora (R7). A contingência para operações se baseia em procedimentos operacionais que possam ser realizados por outras equipes em caso de indisponibilidade (R4). Começando de seu portfólio, que é bastante consistente e padronizado, voltado à terceirização de serviços de TI e processos dos clientes (D3). Para corroborar esta atitude perante riscos, a organização aponta como seu principal diferencial sua sólida estruturação em processos (D4). Desta forma busca uma maneira padronizada de atender a seus clientes de maneira a alavancar seus recursos, incentivando a melhoria contínua nas operações. Internamente a organização pode obter maior eficiência uma vez que opera com ferramentas e processos comuns, aumentando a produtividade das equipes (D10).

A estruturação por processos estabelece um guia a ser seguido e explicita conhecimentos que poderiam ficar somente na mente de alguns indivíduos, o que é essencial numa atividade de central de serviços (Service Desk), que pode contar com uma rotatividade (turn over) alta. Os processos também colaboram para deixar claro a todos os profissionais o porquê das atividades serem feitas de determinada maneira, uma vez que são ligados diretamente às entregas para os clientes (D9).

A totalidade dos clientes possui algum tipo de medida de continuidade dos negócios, sendo que os três maiores possuem estrutura de site de contingência a quente (reestabelecimento imediato das operações em caso de desastre). Atualmente como medidas de segurança da informação que têm influenciado as decisões de investimentos foram citadas as regulamentações externas (R2, R3, R5), como medidas da Justiça do Trabalho referentes à CLT (Consolidação das Leis Trabalhistas) e PCI-DSS (Payment Card Industry, Data Security Standard). Estes investimentos precisam ser previstos em orçamento, levando em conta o risco de serem ou não implantados, uma vez que se trata de uma decisão externa à organização. O provisionamento ou não destes recursos cabe ao diretor de cada área, normalmente voltada a uma visão conservadora de evitar riscos.

Sobre a CLT, há pontos que exigem adequações do quadro de profissionais com relação a horários, sobreavisos e caracterização de vínculos empregatícios, principalmente no que tange a utilização de profissionais ou empresas terceirizadas para execução de atividades. Posicionar 
um profissional nas instalações do cliente sem a devida caracterização da prestação de serviços por parte da organização é considerado como vínculo empregatício do mesmo com o cliente, incorrendo em riscos jurídicos. O papel de organizações parceiras ou terceiras fica em segundo plano, levando apenas em consideração no momento da contratação o respeito às leis trabalhistas (R1).

Já o PCI-DSS, principalmente focado nos grandes clientes do segmento financeiro, causa grande investimento em novos processos e arquitetura de TI para atendimento dos requisitos regulatórios de pagamento com cartão de crédito. Em ambos os casos, estas devem ser levados e explicados aos clientes, para que entenda a real necessidade das mudanças aplicadas, porque implicam em alteração de preço de contratos vigentes.

A preparação e treinamento dos profissionais passam por um ciclo de melhoria contínua: uma vez que são apresentados pelos gestores os processos da organização e as métricas de desempenho, o profissional conhece o que precisa ser feito para cumprir seus objetivos (D9, R6). O trabalho contínuo sobre educação continuada foi apontado como fator mais crítico para manutenção do sistema de governança de TI, uma vez que exige comprometimento e investimento por parte de toda a organização: liderança e profissionais (D13).

Mesmo com uma atitude conservadora perante o risco, a organização admite que mudanças são constantes nas atividades que precisam ser feitas. Portanto, incentivam o ciclo de melhoria contínua e comparação entre operações, fazendo com que cada parte das solicitações de mudanças seja avaliada e implantada na prática com um conjunto que abarque as necessidades de diferentes pontos de vista, primordialmente atendendo aos clientes. As mudanças são rapidamente comunicadas, de maneira estruturada, às equipes operacionais para evitar erros (R10).

O gerenciamento da configuração, com relação a ativos internos envolvidos na prestação de serviços de TI, acaba ficando em segundo plano, uma vez que se tratam as informações relevantes aos outros processos, como gerenciamento de incidentes, problemas e mudanças, que afetam diretamente a operação dos clientes (R8). 


\subsubsection{Pontos mais relevantes do caso}

Definir um gestor de serviços para acompanhar os resultados de cada contrato internamente e junto aos clientes aumenta o grau de relacionamento e confiança dos contratantes. Desse modo os planos de ação de melhoria possuem maior foco e são acompanhados até sua conclusão.

Os processos, acompanhando do ciclo de treinamento e desenvolvimento dos profissionais, trazem o conforto para os gestores de que a organização de que os erros operacionais podem ser diminuídos através de maior controle das atividades dos profissionais.

A organização promove troca de melhores práticas entre áreas pela gestão à vista dos indicadores. Desta forma é possível aproveitar desenvolvimentos feitos em um cliente em outras contas, economizando esforços e divulgando conhecimento.

\subsubsection{Outros comentários dos entrevistados}

O entrevistado demonstrou interesse na classificação de critérios de segurança da informação, principalmente quando relacionada a riscos. Neste caso o entrevistador apresentou a referência bibliográfica desta classificação para poder discutir melhor os critérios.

Apesar da postura conservadora quanto a riscos (Q18), a área cultiva uma cultura de não rejeitar propostas e demandas que venham das demais ou dos clientes diretamente: através de um processo mais longo, porém de resultados mais positivos mostrados pela prática, promove-se um diálogo interno entre as áreas, buscando alinhamento entre as demandas e reais possibilidades de entrega. Deste modo a organização procura equilibrar seu conservadorismo com a flexibilidade exigida pelas mudanças.

\subsection{Empresa 4}

\subsubsection{Qualificação}

- Origem: brasileira;

- Ano da obtenção da certificação ISO 20.000: 2011;

- Número de profissionais: mais de 2.500; 
- Cargo dos entrevistados: Gestora de operações (12 anos e 6 meses no cargo);

- Atitude da organização perante o risco: conservadora (Q18: "reduz/mitiga os riscos");

- Período da coleta de dados: julho a agosto/2014.

- Como é o processo de decisão sobre investimentos em TI (Q4): há muita autonomia para a área que cuida das operações específicas dos clientes (D5). Devido à recente fusão, aumentam os controles de governança corporativa, sendo necessário envolvimento do board para decisões de apresentação de propostas a clientes (R11).

- Investimento em certificações, treinamentos, consultorias e atividades internas específicas para a certificação ISO 20.000 (Q5): não foi informado, porém a organização divulga ter sido a primeira organização no Brasil, no ramo de centrais de serviços, a obter a certificação.

- Quais outros modelos de referência de práticas de governança de TI sua organização adota (Q6): ITIL e PMBoK (D13).

- A empresa investiu em certificação para os profissionais nestes modelos de referência (Q7): sim.

- Com relação à estratégia de implantação da norma (Q8): a pergunta não havia sido respondida através do questionário da primeira fase, verificou-se que a organização possuía processos nos controles das operações que puderam ser adaptados aos requisitos da norma ISO 20.000. As demandas de mercado, como exigências formais por parte dos clientes, geram a necessidade da certificação (R3).

Empresa 4 é brasileira, cujas operações se iniciaram na década de 1980 com foco em terceirização de serviços de TI, especialmente as atividades de Central de Serviços e serviços em campo. Possui filiais na Argentina, Chile, Inglaterra e mantém alianças operacionais nas Américas, além de atuar remota e presencialmente em mais de cem países, oferecendo suporte tecnológico em 12 idiomas.

Seu portfólio inclui central de serviços, call center, suporte a sistemas de TI, serviços gerenciados e terceirização de TI através de seus data centers.

A organização tinha como modelo de governança a base em seus sócios-proprietários. Devido a uma recente fusão com outra organização, também certificada ISO 20.000, houve mudança no modelo acionário. As práticas de governança corporativa são mais rigorosas com relação à auditoria de custos comparados aos orçamentos de cada operação, bem como a decisão de fazer 
proposta aos clientes, aceitando ou não suas condições: o nível de customizações esperado será menor.

Seu portfólio de serviços compreende central de serviços e serviços em campo para atendimentos e suporte técnico a usuários de TI (computadores, aplicações, impressoras e outros periféricos).

\subsubsection{Resumo do caso}

O desempenho está muito focado na maneira em que os profissionais se portam para atender aos requisitos dos clientes (D2). Estes são conhecidos pelo time de operações somente após o fechamento do contrato. Com a fusão haverá participação do time de operações antes do fechamento do contrato para poder opinar em condições que se podem ou não aceitar, ou que precisam de ajustes.

O diferencial da organização é ser flexível para atender aos requisitos de seus clientes (D3), apoiado na execução das atividades do dia-a-dia pelos profissionais de atendimento (D4).

O processo de melhoria contínua inclui a documentação de procedimentos na operação: isto ajuda fundamentalmente na produtividade da equipe. Esta é a principal métrica operacional a ser cumprida: executar as atividades com qualidade percebida pelo cliente, mas de modo a consolidar conhecimento para administrar o turnover e acelerar a resolução de incidentes conhecidos (D6). Outra consequência é a diminuição de erros operacionais (R6), considerado o maior risco para atingir os objetivos de negócio. Com relação aos clientes, são apresentados indicadores relacionados a sua satisfação e os requisitos contratuais são sempre repassados para a equipe operacional (D7).

Há análises de tendências sobre os chamados que permitem identificar quais são reincidentes, que poderiam ser mitigados com procedimentos específicos. O processo não foi chamado de gerenciamento de problemas ou de níveis de serviço, como prescrito na norma ISO 20.000, porém as práticas são as mesmas definidas no modelo canônico. É preciso que as equipes operacionais dediquem parte de seu tempo para documentar procedimentos, fazendo com que o conhecimento se torne explícito e menos dependente da presença de indivíduos. Cabe aos 
gestores estabelecer uma relação entre o investimento em descrever procedimentos e executar em alto volume as atividades do dia-a-dia (atendimento de chamados).

Observando a camada operacional, nos times alocados a um cliente específico, por exemplo, busca-se direcionar este comportamento. A gestão força com que os procedimentos sejam documentados ou sempre o mesmo profissional é alocado a sua resolução, ou procurado pelos outros para auxílio. Isto diminui sua produtividade individual e prejudica suas métricas. Com os procedimentos, a equipe consegue atender aos chamados sem recorrer a ele, que pode continuar com métricas satisfatórias de desempenho individual.

Não foi dado destaque à participação de terceiros, uma vez que a organização busca prestar os serviços diretamente com mão-de-obra própria (D1). Internamente, a percepção inicial do profissional é de que se possui um conhecimento é imprescindível e pode colaborar com a empresa (D8). Porém é levado a construir uma base que explicita seus conhecimentos fazendo com que a operação possa se sustentar. Alguns profissionais são levados a cada dois meses nas reuniões mensais de acompanhamento de resultados com o cliente, para que possam ver o impacto de suas ações e entender as pressões exercidas sobre sua área diretamente de quem os contrata.

Os treinamentos são realizados periodicamente com os times (D8), principalmente na parte comportamental. Com objetivo de aumentar a satisfação dos clientes, mostra-se e se discute a importância das atividades técnicas com relação ao negócio-fim do cliente. O senso de urgência de atendimento se torna mais adequado ao ambiente. Muito do aprendizado técnico se dá através do desenvolvimento dos procedimentos e no dia-a-dia da operação. As avaliações individuais ocorrem a cada quatro meses, através da consolidação das métricas que são acompanhadas no dia-a-dia, sempre focadas em produtividade e satisfação do cliente (D9).

As métricas de desempenho são acompanhadas mensalmente com os clientes, em reuniões presenciais (D10, R9), sendo avaliadas internamente com a equipe inicialmente e depois na presença dos clientes (D11). O orçamento da operação é acompanhado, sendo que riscos e possíveis desvios são discutidos com o cliente (D12) sendo reavaliados com a direção da organização para necessidade de investimentos. 
A infraestrutura de TI necessária para atendimento dos clientes é decidida cliente a cliente, de acordo com os requisitos específicos solicitados (D14, R8), vinda da necessidade de transferência de riscos do cliente (R2). A parte comum, como escritório, ferramenta de gerenciamento de chamados, é mantida para consistência e produtividade da operação. Neste ponto, foram destacados como benefícios da utilização da norma ISO 20.000 os processos de entrada de um cliente (on-boarding), em que se detalha a árvore de atendimento a chamados; e de geração e manutenção dos procedimentos de trabalho das áreas (D13).

Apesar do questionário trazer a informação de conservadorismo perante o risco (Q18), verificou-se durante a entrevista que a organização acaba se expondo bastante a riscos, na busca de seus contratos, uma vez que procura atender às demandas dos clientes conforme especificadas em suas requisições de propostas (RFP) ou editais. Os riscos são identificados durante a operação e endereçados junto a outras áreas internas e com o cliente, porém o compromisso em atender os requisitos já está firmado (R7).

Com a entrada do controle acionário da nova organização, devido à aquisição, os controles sobre as decisões de assumir contratos com clientes são maiores. Espera-se uma disposição menor para customizações e para reduzir riscos. A decisão de investimentos que era muito focada em cada operação, agora será corporativa (R1).

Não foram identificadas medidas de continuidade de negócio além de procedimentos escritos (R4), o que é compatível com a falta de visibilidade sobre ameaças externas de segurança da informação (R3).

Como riscos internos, apontam-se os erros operacionais (R6), causados por desempenho indevido dos profissionais (R5). Os ativos de TI só são controlados se tal serviço for contratado pelo cliente (R8). A tomada de decisões é feita sobre planos de ação acompanhados regularmente dentro da equipe e com os clientes (R9), porém mudanças são feitas conforme necessário, sem um efetivo controle (R10). 


\subsubsection{Pontos mais relevantes do caso}

O processo de on-boarding permite a definição de práticas para atendimento específico de um cliente, deixando o conhecimento da equipe nivelado para o início das operações.

A gestão da equipe é bastante valorizada e presente, sempre buscando identificar necessidades de melhoria e comunicar o porquê do trabalho dos profissionais, através das métricas individuais. Esta gestão é complementada pela divulgação e documentação de procedimentos operacionais, que gera uma pressão sobre os profissionais.

\subsubsection{Outros comentários dos entrevistados}

O entrevistado comentou sobre a importância de desenvolver os profissionais quanto a seus conhecimentos técnicos e sua conscientização, uma vez que estas capacitações estão diretamente ligadas a suas atividades para o negócio e desempenho dos clientes, como um círculo virtuoso: ao serem mais bem atendidos, os clientes contratam mais serviços e há mais oportunidades para desenvolvimento dos profissionais.

\subsection{Empresa 5}

\subsubsection{Qualificação}

- Origem: brasileira;

- $\quad$ Ano da obtenção da certificação ISO 20.000: 2008;

- Número de profissionais: entre 100 e 1.000;

- Cargo dos entrevistados: Gerente de serviços de TI (6 anos na organização);

- Atitude da organização perante o risco: conservadora (Q18: "reduz/mitiga os riscos"). Porém durante a entrevista notou-se ser uma empresa que aceita os riscos;

- Período da coleta de dados: julho a agosto/2014.

- Como é o processo de decisão sobre investimentos em TI (Q4): através do corpo diretivo em conjunto com o presidente (D11). 
- Investimento em certificações, treinamentos, consultorias e atividades internas específicas para a certificação ISO 20.000 (Q5): 20\% do orçamento da área do entrevistado são voltados a treinamentos.

- Quais outros modelos de referência de práticas de governança de TI sua organização adota (Q6): ITIL (incluindo certificações), Cobit, PMBoK e BSC (D13).

- A empresa investiu em certificação para os profissionais nestes modelos de referência (Q7): sim.

- Com relação à estratégia de implantação da norma (Q8): a pergunta não havia sido respondida através do questionário da primeira fase, verificou-se que a organização possuía processos nos controles das operações que puderam ser adaptados aos requisitos da norma ISO 20.000 .

Empresa 5 é brasileira, cujas operações se iniciaram na década de 1990 com foco na integração de infraestrutura de tecnologia da informação. Inicialmente atuava em projetos de cabeamento e passou a atuar em serviços de TI devido a oportunidades encontradas no mercado.

Seu portfólio de serviços compreende central de serviços e serviços em campo - dentro das instalações do cliente - para atendimentos e suporte técnico a usuários de TI (computadores, aplicações, impressoras e outros periféricos). A organização tem como modelo de governança a atuação do presidente junto aos diretores das áreas para discussão e validação das decisões.

\subsubsection{Resumo do caso}

O desempenho está muito ligado à qualidade que os clientes percebem nos serviços entregues, bem como no relacionamento estabelecido no dia-a-dia (D2). A organização possui uma área de qualidade independente, que ajuda na entrega de resultados aos clientes e auditoria dos processos internos. O painel de indicadores dos clientes é revisto trimestralmente com a diretoria e mensalmente com os clientes (D6).

O portfólio da organização cresceu e ainda é mantido para atender ao escopo de editais e solicitações de proposta (RFPs - Request For Proposals) recebidas do mercado (D3). As decisões sobre os investimentos e participação em propostas são tomadas entre os diretores das diferentes áreas e o presidente (R1, R11), determinando os investimentos necessários e suas 
prioridades (D5, D12). Porém muitos investimentos ainda são feitos de modo reativo, após a experiência de indisponibilidades de serviços a clientes, uma vez que TI ainda é vista como "bombeiro" para situações de emergência.

A área comercial é responsável por trazer a demanda do mercado. Os analistas são divididos entre desenvolvedores de soluções e executores (entrega), porém ficam fisicamente próximos para poder discutir assuntos relacionados aos clientes (D7). Isto também agiliza o processo de verificação de não-conformidades de uma operação, porque são determinadas ações preventivas e corretivas relacionadas à satisfação do cliente de maneira mais rápida. Os resultados das operações são medidos com relação aos requisitos iniciais dos clientes, sendo acompanhados periodicamente pelos gerentes e diretores (D10). A partir dessas métricas, planos de ação são gerados e acompanhados até sua conclusão dentro de cada operação (R9).

A formação e conhecimento dos profissionais são considerados os maiores diferenciais da organização (D4). A participação de terceiros não foi destacada, uma vez que a organização busca ter os times em regime CLT para atender aos contratos (D1). A área de recursos humanos é envolvida para desenvolver os planos de carreira (D8). Os investimentos em treinamentos são baseados em necessidades estratégicas, de acordo com as demandas de entrega para clientes. A organização foi criando uma biblioteca de conhecimento própria ao longo dos anos em que investiu nos treinamentos, possuindo material e ambiente de laboratório à disposição dos profissionais para utilização no seu desenvolvimento pessoal (D9). As mudanças são constantes (R7) e a organização lida com isso complementando sempre os treinamentos dos profissionais e documentando as mudanças através de procedimentos internos (R10).

Sobre a importância da norma ISO 20.000 para a organização, o entrevistado destacou como causa principal da busca da certificação as exigências em editais presentes no mercado. Internamente, o processo de gerenciamento de incidentes foi destacado, uma vez que se tenta minimizar o impacto aos serviços do cliente. Também é usado para gerar uma conscientização entre os profissionais com relação à importância de seu trabalho (D13). O gerenciamento dos processos contribuiu com a redução de retrabalho, que era causado comumente pela entrada de novos contratos no período de boom de vendas ocorrido há cinco anos. O processo de gerenciamento de configuração é colocado em segundo plano, uma vez que é difícil apresentar benefícios e valor diretamente de sua utilização (R8, D14). 
Sobre riscos a organização está constantemente analisando seus concorrentes para verificar o que estão fazendo de novo para se posicionarem adequadamente (R2). Por estar presente em um mercado mais específico geograficamente, foram apontados como riscos internos à segurança da informação a engenharia social e o vazamento de informações (R3, R5). Os acessos a dados internos da organização sofrem diversas restrições lógicas (acesso VPN restrito a poucos profissionais em cargos de confiança) e físicas (como o controle de dispositivos móveis e portas USB). Os riscos apontados com relação ao desempenho dos serviços são relacionados a erros operacionais que os profissionais possam cometer (R6).

Os clientes têm solicitado soluções de continuidade de negócios, porém não é um conhecimento consolidado na organização (R8). A organização conta com um plano de recuperação de desastre. Estas soluções são implantadas reativamente, conforme demandas específicas dos clientes, como um que possui uma sala de contingência a frio (sala vazia, preparada para uso em caso de desastre, porém sem a cópia dos dados ou acesso a sistemas específicos).

Um entendimento sobre a aplicação do modelo canônico na realidade da organização é como "tentar vestir a roupa do vizinho": cada um tem suas necessidades específicas e precisa adaptar o uso do modelo a sua realidade. A aplicação das práticas deve ser orientada pelo objetivo principal de atender aos requisitos dos clientes, analisando processo a processo para estabelecer o quanto a governança deve se aprofundar na definição dos critérios de execução de atividades do dia a dia.

O investimento feito pela organização para a obtenção e manutenção da certificação, vista como fundamental para a participação de processos comerciais no mercado foi alto e deve ser preservado. Os treinamentos e certificações individuais ajudaram a estabelecer uma linguagem comum, tornando as reuniões internas e com clientes mais produtivas, dado o melhor entendimento entre as partes.

O modelo de governança e os processos são usados como um modo de adequar o profissional às características desejadas pela organização, uma vez que através da visibilidade dos resultados e clareza dos objetivos é possível expor como a alta direção quer que o comportamento dos profissionais seja: erros técnicos são mais tolerados que atitudes de não seguir os processos estabelecidos. 


\subsubsection{Pontos mais relevantes do caso}

O investimento em treinamentos foi destacado como mecanismo para preservar os diferenciais da organização e a motivação dos profissionais na prestação dos serviços. Os clientes valorizam esta orientação, uma vez que verificam resultados na prática com profissionais mais preparados para lidar com as situações da operação.

Da perspectiva interna, este investimento diminui o retrabalho e permite o ganho de escala das operações. Embora leve à grande dependência da organização sobre os profissionais: um compromisso que faz seu maior diferencial (D4) tornar-se seu maior risco (R2, R5).

A organização está aberta a riscos, pois tem como grande objetivo o crescimento. O papel da governança de TI é de modelar o comportamento dos profissionais para minimizar os riscos operacionais. A organização investe em seus profissionais, mas exige os resultados de volta.

\subsection{Empresa 6}

\subsubsection{Qualificação}

- Origem: brasileira;

- Ano da obtenção da certificação ISO 20.000: 2011;

- Número de profissionais: entre 1.001 e 2.500;

- Cargo dos entrevistados: Diretor de serviços (2 anos e 4 meses na organização);

- Atitude da organização perante o risco: conservadora (Q18: “reduz/mitiga os riscos");

- Período da coleta de dados: maio a agosto/2014.

- Como é o processo de decisão sobre investimentos em TI (Q4): através de dois boards: um dos sócios ingleses e outro dos sócios brasileiros (D11).

- Investimento em certificações, treinamentos, consultorias e atividades internas específicas para a certificação ISO 20.000 (Q5): R \$ 20 mil ao ano (somente para a área de serviços).

- Quais outros modelos de referência de práticas de governança de TI sua organização adota (Q6): ITIL (incluindo certificações), Cobit, SixSigma, PMBoK (D13). Sobre BSC houve somente investimento em treinamentos e certificações de profissionais. 
- A empresa investiu em certificação para os profissionais nestes modelos de referência (Q7): sim.

- Com relação à estratégia de implantação da norma (Q8): a pergunta não havia sido respondida através do questionário da primeira fase. A principal razão apontada para adoção da norma é tratar de maneira mais adequada os riscos, gerenciando melhor a operação evitando perdas financeiras, com retrabalho ou indisponibilidade dos serviços por exemplo.

Empresa 6 é brasileira, cujas operações em tecnologia da informação se iniciaram na década de 1970 com ênfase na integração de infraestrutura de tecnologia da informação. Seu foco sempre foi voltado ao gerenciamento de projetos e integração de soluções. Na década de 2000 passou pela fusão com uma organização inglesa, aumentando sua presença global, com atuação intensificada na América Latina em 10 países.

Seu portfólio compreende serviços gerenciados sobre soluções de tecnologia implantadas pela organização, ou sobre infraestrutura que os clientes já possuam. A organização tem como modelo de governança para decisões de investimento em TI (Q5, D12) a atuação do presidente junto ao board de executivos ingleses e ao outro de investidores brasileiros. Neste segundo soma-se a consideração de que os profissionais são acionistas da organização, fazendo com que as decisões tomadas em seu dia a dia afetem diretamente seu investimento.

Investimentos são sempre justificados sobre as necessidades específicas trazidas por clientes (D14). Com relação a melhorias na infraestrutura atual, o entrevistado ainda não julga necessário, pois esta é bastante nova. Tal processo é longo, dependente de que a ideia vá ganhando a confiança dos tomadores de decisão.

Quanto às decisões de negócio de dia a dia, como participar de processos comerciais de clientes ou atuações na operação, os diretores possuem autonomia junto às informações apresentadas pelos gerentes (D5). 


\subsubsection{Resumo do caso}

O desempenho está diretamente relacionado à qualidade percebida pelos clientes sobre os serviços entregues (D2). Este resultado é verificado através das reuniões mensais decorrentes da entrega dos indicadores de níveis de serviço.

O portfólio de serviços cresce acompanhando o conhecimento atual de seus profissionais, expandindo por adjacência as proposições de integração de tecnologia (D3). A organização também promove análises de mercado e concorrência, buscando atender a nichos de clientes que estejam em busca de soluções customizadas para demandas específicas.

Sobre o relacionamento com parceiros da organização, em particular na prestação de serviços aos clientes, é difícil garantir que os terceiros teriam a mesma atitude dos profissionais próprios para o atendimento aos clientes (D1). Uma das medidas estudadas pela organização é implantar um pacote mínimo de exigências à área de suprimentos para ampliar os requisitos comerciais a questões técnicas, como se fosse uma certificação particular, para validar as pessoas que prestarão serviços.

Os processos da organização foram destacados como seu principal diferencial no mercado (D4). Porém o entrevistado chamou a atenção para aprofundamento inadequado dos processos: citou que o excesso de controle diminui o desempenho do negócio, principalmente quando estabelece um nível de exigência de maturidade maior que a capacidade de entrega dos profissionais.

Como principal problema no gerenciamento do desempenho de TI, foi apontada a diferença de expectativas entre o escopo prometido, o vendido e o entregue de fato (D6). Sendo assim, o relacionamento do dia a dia com o cliente ganha importância para que suas demandas e necessidades sejam entendidas e atendidas o mais rápido possível. $\mathrm{O}$ impacto de mudanças necessárias para tal atendimento deve ser discutido dentro da realidade financeira da operação (D7). Os investimentos são reavaliados ao longo do período em conjunto com a alta direção (D12) e as aprovações são dadas pelos dois boards de acionistas (R1) de acordo com as práticas de governança corporativa estabelecidas entre as partes. Há forte pressão dos acionistas sobre as decisões tomadas principalmente com relação a ampliações ou investimentos adiantados para novos negócios (R11). A infraestrutura voltada à criação de novos serviços no portfólio foi adquirida após uma avaliação de caso de negócio (business case) (D14). 
A organização conta com uma estrutura horizontal ao organograma convencional para cuidar do planejamento e desenvolvimento de carreira dos profissionais, bem como sua alocação nas diferentes atividades. Assim se busca equilibrar a estratégia da organização com as necessidades de desenvolvimento profissional. Os profissionais são desenvolvidos através de um programa interno de treinamentos, em que eles próprios têm a possibilidade de auto proposição de cursos que gostariam de fazer (D8). Um comitê da organização julga a relação destas proposições com a estratégia e necessidades do negócio e aprova os treinamentos dentro do orçamento estabelecido. Os profissionais recebem os treinamentos, podendo optar por utilizar horas comuns de trabalho, pagas pela organização, ou horas doadas, podendo assim fazer mais horas de treinamento no mesmo período (D9).

Quanto a conscientizar cada profissional da importância de seu trabalho com relação ao desempenho junto ao cliente continua uma tarefa complexa. Pela distribuição de tempo, sempre se prioriza o atendimento de incidentes e recuperação do ambiente produtivo dos clientes.

Para evidenciar o desempenho das operações, a organização possui processos para aferir os indicadores mensalmente. Uma área dentro da diretoria de serviços é responsável pelos processos, gerenciamento dos projetos e geração dos relatórios com as métricas internas e dos clientes (D10).

Os principais riscos apontados são operacionais (R6), porém não relacionados ao conhecimento técnico dos profissionais, mas àqueles considerados soft skills: relacionamento com o cliente, tratamento e entendimento da necessidade do outro.

A atitude da organização ante os riscos é bastante conservadora (R7), sendo que erros financeiros nas operações são pouco tolerados. Porém, erros relacionados à inovação e ao atendimento de necessidades dos clientes são em sua maior parte relevados, permitindo certa liberdade aos profissionais para buscar melhorias e satisfação de seus clientes. A organização possui plano de recuperação de desastres (R4), que permite a continuidade dos serviços de TI em caso de desastre. Quanto à segurança da informação, o gestor apontou internamente o erro na integridade de informações (R5) sendo que muitas atividades são feitas de forma "artesanal" (caso a caso) e não através de procedimentos documentados. Externamente destacou o 
cumprimento e respeito às leis trabalhistas que precisam ser observadas por todos os competidores deste setor do mercado (R3).

Sobre os processos de terceirização de serviços de TI, o gestor acredita que muitas vezes são feitas para transferir os riscos para outra organização (R2), o que acarreta em problemas durante a vigência do contrato, pois as expectativas do cliente e da contratada são muito diferentes. Ao longo da prestação dos serviços, as métricas são colhidas e são gerados relatórios para determinar planos de ação e de melhoria das operações (R9). Estas são acompanhadas por um gestor operacional alocado a cada cliente, para buscar o alinhamento de entendimento, de expectativas e a satisfação dos clientes.

As mudanças introduzidas na operação são bem comunicadas (R10). A intranet é amplamente utilizada pelos profissionais e cumpre bem este papel, assim como os líderes locais atuam em comunicações pontuais e locais. O processo de gerenciamento de mudanças é utilizado com rigor, estabelecendo forte controle na operação (D10). Embora seja então um elemento de pressão da organização sobre o profissional, o gestor entrevistado desde seu ponto de vista entende que este mecanismo serve como proteção para o profissional, uma vez que evita atividades que possam causar indisponibilidades ao cliente ou a duplicação de atividades.

O processo de gerenciamento de configuração foi alvo particular de várias atividades de melhoria. O objetivo era garantir que, através desta informação, se soubesse com clareza se determinado serviço ao cliente deveria ou não ser realizado, por exemplo a troca de equipamentos defeituosos que não estão na base contratada: geram custos sem receita associada (R8). Porém ainda há muitos problemas na e os reais benefícios ainda não foram capturados.

\subsubsection{Pontos mais relevantes do caso}

A relação de equilíbrio entre os acionistas, para seguir o modelo de governança corporativa, é bastante presente no processo de tomada de decisão da empresa.

Investir em treinamento e carreira dos profissionais ajuda na qualidade dos serviços prestados aos clientes. Em contrapartida, a organização busca maior controle sobre as atividades que precisam ser executadas através de métricas de desempenho. 
O sistema de processos de governança de TI gera pressão sobre os profissionais, embora o ponto de vista da gestão seja apresentá-los como uma possível defesa: em caso do erro ocorrer numa situação em que esteja respaldado pelo processo, pode ser aceito pela liderança. Isto leva a uma identidade conflituosa na tentativa de equilibrar inovação e controle.

A certificação é vista como redução de risco ao evitar a perda de dinheiro por controlar erros operacionais que poderiam levar a indisponibilidade de serviços.

\subsubsection{Outros comentários dos entrevistados}

A contratação de serviços no mercado ainda sofre com problemas de especificação. Os profissionais acabam se preocupando muito do lado de requisitos técnicos e funcionamento da tecnologia, ao invés de estruturar os requisitos de negócio. Níveis de serviço, disponibilidade, regras claras para crescimento e diminuição, feitas através das medições e aditivos contratuais, são deixados de lado durante o processo de negociação, causando problemas durante a entrega (D8).

Para clientes que não possuem governança, há um choque natural na contratação de serviços de empresas especializadas. Porém um dos motivadores principais dos clientes apontado pelo entrevistado é forçar a melhoria de sua organização uma vez que terá que se adequar a parte dos processos colocados pela contratada.

Destaca que houve certa banalização de alguns serviços de TI (como o Service Desk), que tiveram forte pressão de redução de preço por parte de prestadores do mercado. Com este referencial estabelecido, foi preciso retirar escopo e qualidade dos mesmos, pois sua oferta não seria competitiva no mercado. 


\section{7 $\quad$ Empresa 7}

\subsubsection{Qualificação}

- Origem: brasileira;

- Ano da obtenção da certificação ISO 20.000: 2011;

- Número de profissionais: 350 (100 a 1.000);

- Cargo dos entrevistados: Diretor de operações (10 anos na organização, 2 anos e 10 meses na função);

- Atitude da organização perante o risco: aceita o risco (Q18);

- Período da coleta de dados: julho a agosto/2014.

- Como é o processo de decisão sobre investimentos em TI (Q4): informações gerenciais são levadas aos diretores-sócios da organização para decisões quanto às soluções a serem aplicadas nas operações (D14).

- Investimento em certificações, treinamentos, consultorias e atividades internas específicas para a certificação ISO 20.000 (Q5): cerca de R\$ 30 mil / ano.

- Quais outros modelos de referência de práticas de governança de TI sua organização adota (Q6): ITIL e PMBoK.

- A empresa investiu em certificação para os profissionais nestes modelos de referência (Q7): sim.

- Com relação à estratégia de implantação da norma (Q8): os processos para a área operacional compartilhada foram criados a partir dos requisitos da norma.

Empresa 7 é brasileira, tendo 15 anos de atuação no mercado nacional em seis estados. Seu portfólio sempre foi voltado para serviços de integração e terceirização (outsourcing) de serviços de tecnologia da informação. Atendem como especialidade à vertical de manufatura de papel e celulose, além de atuar nos mercados de mineração, commodities, saúde e governo.

A organização possui dois diretores-sócios e outros dois que fazem parte do board de governança (R1, R11). As operações verificam individualmente suas necessidades relacionadas a atualizações e atendimento a demandas dos clientes e apresentam as propostas de investimento para o board. A cada seis meses são propostos lotes de investimento para aprovação (D12). Os controles e acompanhamento financeiros são feitos operação a operação, 
não havendo um orçamento centralizado de TI para investimentos de melhoria na infraestrutura (D5).

Nos últimos três anos a empresa dobrou de tamanho, em número de funcionários. Este crescimento se deu à expansão de mercado por outros estados e acompanhou o processo interno de certificação ISO 20.000. O trabalho com processos padronizados com relação ao modelo canônico auxiliou a organização a ganhar escala neste novo volume de trabalho. Nota-se que a organização é orientada individualmente por operação, e a certificação ISO 20.000 auxiliou no estabelecimento de práticas comuns a serem compartilhadas por estas operações e seus gestores, permitindo a criação de um centro de serviços compartilhados.

Com base no questionário da primeira fase, alguns pontos foram questionados novamente para confirmação e entendimento com relação à qualificação da organização (Erro! Fonte de referência não encontrada.). Desta maneira é possível comparar a empresa estudada às demais de acordo com suas características.

\subsubsection{Resumo do caso}

O desempenho da organização é medido interna e externamente. Internamente, são apresentados relatórios de cada operação, divididos por assuntos: tecnologia, processos e pessoas, trazendo uma perspectiva mais ampla para possíveis melhorias. Reclamações e elogios dos clientes são apresentados como insumo da análise do desempenho.

Do ponto de vista dos clientes, são apresentados relatórios mensalmente em reuniões presenciais. O gerente de suporte tem o papel na organização por conduzir estes encontros, apresentar os indicadores relacionados aos níveis de serviço contratados.

Há uma área independente da qualidade, que não responde aos diretores de operações mas diretamente aos sócios, que auditam as operações segundo sete critérios: avaliação de satisfação dos clientes, cumprimento dos níveis de serviço, capacitação da equipe, lucro, faturamento, feedback do time e avaliação comportamental do gestor (com pontos de vista dos clientes, pares e funcionários). Desta forma avalia-se a saúde financeira de cada conta, o atendimento aos 
requisitos dos clientes e a parte comportamental do gestor, que não pode obter seus resultados a qualquer modo.

Os dois diretores-sócios cumprem uma função relacionada à satisfação do cliente ao visitá-los pessoalmente para saber detalhes sobre o desempenho das operações (D2). Especificamente para os contratos de outsourcing, a gestores por região que visitam seus clientes. Através dos fóruns de governança, são promovidas trocas de experiência e melhores práticas, que podem ser aplicadas pelos outros gestores. Muitas vezes se detectou que a reclamação de um cliente é o elogio do outro.

As pessoas são apontadas como seu principal diferencial (D4), entendendo a prestação de serviços de TI como a construção de relações de longo prazo com os clientes. As relações com terceiros são esporádicas, uma vez que a organização busca atender a seus contratos com profissionais contratados em regime CLT. Quando utilizados, os terceiros são avaliados quanto a suas entregas (D1). Quanto ao portfólio, a organização se divide na entrega de projetos e em operações de outsourcing, sendo estas o foco desta pesquisa (D3). Ao entender que as necessidades de cada cliente são diferentes, o portfólio não é construído de modo a criar pacotes de serviços, e sim customizar a operação para os requisitos específicos. Com isso se busca estabelecer grande grau de confiança entre prestador e cliente, ao se apresentar como uma empresa flexível a clientes que sofreram problemas operacionais ao trabalhar com organizações cujos processos são mais padronizados e impositivos.

Como principais desafios enfrentados para manter os níveis adequados de desempenho nas operações, são citados a escassez de mão-de-obra qualificada, que se torna um limitador ao crescimento da organização, e o processo de comunicação com o cliente, uma vez que se devem gerenciar as expectativas entre o que foi vendido e o que é entregue, ao longo de toda a vigência do contrato (D6, D7). Os resultados de negócio são medidos com relação aos requisitos iniciais dos clientes (D10), sendo avaliados pelos gestores de cada operação com os diretores da organização (D11, R9).

A capacitação dos profissionais é observada em cada operação (D8). Não há programas de treinamento formalizados ou investimentos centralizados (D9). As necessidades são levantadas em cada operação pelo gestor, cliente e sua equipe e dentro do seu orçamento são alocadas as capacitações requeridas. 
O principal risco apontado pelo entrevistado é a pressão competitiva (R2). Entende como desvantagem de sua organização, em comparação às principais concorrentes nas atividades de outsourcing, a credibilidade por ser uma empresa relativamente pequena e jovem. Estes levam vantagem por imagem, presença nos grandes centros (SP e RJ), preço e credibilidade pelo volume de casos de sucesso que possuem.

Medidas têm sido adotadas com relação à segurança da informação, como instalação de câmeras, acesso controlado por biometria além de adequar as operações que tenham exigências específicas dos clientes com relação a este tema. Assim a organização busca impedir falsificações de identidade para execução de atividades ou acesso a seus dados sensíveis (R3, R5).

A organização conta com estrutura de recuperação de desastres para garantir maior disponibilidade dos serviços a seus clientes, incluindo a estrutura do data center e a localidade física para a operação continuada, através dos dois escritórios da sede (R4).

Apesar da dependência das pessoas, apontadas como diferencial, não foi colocada nenhuma preocupação em especial sobre seu comportamento em relação à segurança da informação (R5). Porém foram implantadas medidas de proteção contra fraudes por acesso indevido. Os riscos operacionais são considerados sobre a disponibilidade dos serviços prestados, em que medidas de contingência fazem parte desde o desenho à operação dos contratos (R6).

A organização precisa estar muito disposta a assumir riscos porque precisa crescer (R7). Nesta situação, acaba tomando muitos riscos diante de novas oportunidades de negócio buscando oferecer operações customizadas aos requisitos dos clientes.

O gerenciamento de mudanças é bastante difundido na organização, sendo que alterações em procedimentos operacionais são comunicados às equipes rapidamente, para evitar problemas operacionais (R10). O gerenciamento dos ativos de TI é feito manualmente, sem controles formalizados em ferramentas de gestão (R8).

O maior motivador para a implantação da ISO 20.000 foi uma expectativa de que o mercado exigiria esta certificação para participação em propostas comerciais (D13), o que acabou não 
se confirmando na prática. Como grande benefício, houve a institucionalização de melhoria contínua na organização, de maneira estruturada. Isto não aconteceu logo da certificação conquistada, mas como um processo que foi amadurecendo ao longo do tempo e positivamente influencia os profissionais que chegam à organização. Dado seu expressivo crescimento nos últimos anos, sua consolidação de práticas é considerada fundamental para manter seus níveis de qualidade.

\subsubsection{Pontos mais relevantes do caso}

Nomear um gestor de serviços para cada contrato se mostrou fundamental no amadurecimento do relacionamento com o cliente, garantindo o alinhamento de expectativas entre as organizações. O acompanhamento de níveis de serviço e planos de ação mostra aos clientes o interesse em prestar o melhor serviço possível dentro dos limites contratados.

O processo promovido para troca de práticas entre regiões, estabelecendo os fóruns específicos por tipo de contrato, faz com que a organização ganhe eficiência ao reduzir a necessidade de cada gestor desenvolver suas próprias práticas para resolver problemas repetidos.

O processo de melhoria contínua se apresenta bastante maduro e presente no dia-a-dia da organização, pautando suas práticas e a conduta dos profissionais. O gerenciamento dos indicadores e o envolvimento de todos com relação a essas entregas fazem com que todos se tornem responsáveis pelos resultados dos serviços de TI prestados pela organização.

\subsubsection{Outros comentários do entrevistado}

O entrevistado citou que é possível amadurecer outros processos que trazem benefícios imediatos, como gerenciamento de incidentes e problemas, sem possuir a base de dados e o processo de gerenciamento de configuração implantado. É difícil provar o resultado imediato deste, já que leva tempo para ser adotado e, por mais que se invistam recursos, parece sempre desatualizado.

Destacou que o crescimento rápido da organização acaba expondo fragilidades que existiam, porém não causavam impacto por estarem mais controladas simplesmente pelo volume de 
trabalho. Ao aumentá-lo, nota-se a necessidade de maior controle sobre algumas práticas, como o gerenciamento de mudanças e de conhecimento, para garantir a entrega dos serviços.

\subsection{Empresa 8}

\subsubsection{Qualificação}

- Origem: brasileira;

- $\quad$ Ano da obtenção da certificação ISO 20.000: 2011;

- Número de profissionais: mais de 2.500;

- Cargo do entrevistado: Gerente de Governança de TI;

- Atitude da organização perante o risco: conservadora (Q18: reduz/mitiga os riscos);

- Período da coleta de dados: agosto a setembro/2014.

- Como é o processo de decisão sobre investimentos em TI (Q4): o processo é feito em conjunto com a participação de diferentes áreas interessadas, através do Comitê de TI.

- Investimento em certificações, treinamentos, consultorias e atividades internas específicas para a certificação ISO 20.000 (Q5): não revelado.

- Quais outros modelos de referência de práticas de governança de TI sua organização adota (Q6): Cobit, ITIL, PMBoK, BSC e CMMI. Para Seis Sigma houve investimentos em certificações para profissionais da organização.

- A empresa investiu em certificação para os profissionais nestes modelos de referência (Q7): sim.

- Com relação à estratégia de implantação da norma (Q8): a organização já possuía os processos, que foram adaptados aos requisitos da norma.

Empresa 8 é uma instituição financeira brasileira presente em todo o país, com amplo portfólio para atendimento a pessoas físicas e jurídicas cujas operações se iniciaram na década de 1940 . Sempre pioneira na utilização de informática em seus processos internos, introduz os computadores na década de 1960 e investe constantemente em atualização de seu parque tecnológico para dar agilidade a seus negócios e garantir a confiabilidade de seus dados. 
Seu portfólio de serviços de TI internos compreende o gerenciamento de todos os elementos de tecnologia, corporativos e transacionais. Apesar de ser uma organização cujo negócio-fim não é TI, sua rentabilidade depende fundamentalmente de tecnologia.

Sua imagem ao mercado é fundamentada em confiança e segurança, portanto indisponibilidades causadas por falhas de tecnologia ou invasões de sistemas causadas por ataques comprometem diretamente seu desempenho.

É uma organização que busca inovações apresentadas pelo mercado para poder evoluir seus sistemas de informação e infraestrutura de TI, apesar de ser muito cautelosa ao introduzir essas novidades no ambiente de produção.

\subsubsection{Resumo do caso}

A organização conta com terceirização de serviços somente em áreas consideradas não fundamentais para o funcionamento da TI em relação a seu negócio-fim (D1). Dentro da área de TI são aproximadamente 3.000 pessoas contratadas diretamente, segundo regras CLT. Isso ajuda a manter a inteligência do negócio dentro da organização. Há cerca de dez anos houve experiências mal sucedidas neste aspecto, que acabaram causando a diminuição da metade do quadro de terceiros, absorvendo-os como profissionais da organização.

Foi institucionalizado um conceito de "cadeia de valor ao negócio" (D7), à qual todas as decisões de tecnologia da informação devem estar alinhadas. Esta cadeia permite a análise de requisitos desde o início através dos analistas de negócio, que trazem diretamente de suas áreas as necessidades a serem implantadas com TI (D2). Estes requisitos são especificados gerando uma requisição que será tratada pelos desenvolvedores de sistemas e aprovadas pelos gestores das áreas envolvidas.

O Comitê de TI é formado por diretores e executivos de todos os departamentos da organização, permitindo que as prioridades sejam estabelecidas em conjunto ao serem observadas em conjunto (D12, D14). Assim o portfólio de serviços internos de TI é definido pelo departamento de tecnologia dos negócios, que busca nas referências de mercado como fabricantes, integradores e concorrentes, quais as tecnologias mais atuais que podem ser aplicadas ao 
negócio (D3). As áreas interagem através do comitê, permitindo um processo participativo mais intenso (D5).

Nas reuniões semanais de comitê também são avaliados os indicadores de desempenho das áreas (D11, R9), bem como acompanhamentos de dados históricos para permitir análises ao longo do período da evolução de desempenho, ou sucesso de planos de ação implantados. Dentro de cada área há indicadores mais detalhados, que são acompanhados por seus gestores para serem apresentados de maneira consolidada no comitê (D6, D10).

A arquitetura de TI foi considerada pelo gestor como principal diferencial de sua organização prestadora de serviços (D4). Ao utilizar uma arquitetura baseada em componentes (SOA: Service Oriented Architecture) e padronizada, houve grande diminuição de retrabalho.

Considerando o alto volume de mudanças tratadas (entre 300 e 400 mensalmente), a padronização ajuda a evitar erros operacionais. As mudanças são tratadas através de um comitê semanal fixo, cujas reuniões são registradas e as solicitações apresentadas para as diferentes áreas, para que todos entendam os riscos associados àquela mudança (R10). Este comitê se desdobra em outros: gerencial, departamental e executivo de acordo com a complexidade da mudança e o risco a que expõe o negócio da organização. Quando há mudanças que alterem processos, são feitos planos de comunicação e treinamento dos profissionais envolvidos (D9). O controle dos ativos de TI é feito através do processo de gerenciamento de configurações, que tem ferramentas específicas para automatizá-lo (R8).

Sobre o desenvolvimento dos profissionais, são estabelecidas carreiras internas juntamente à área de recursos humanos, e se estabelece um planejamento anual para treinamentos e certificações (D8). São incentivadas visitas a fornecedores para manter os profissionais atualizados com o que há de novo em tecnologia e soluções possíveis para a organização.

Ao analisar os benefícios da utilização da norma ISO 20.000 nas operações da organização, aponta-se como maior deles o controle e visibilidade sobre a maturidade dos processos, uma vez que é possível mapear e mitigar erros operacionais de uma maneira mais eficiente (D13).

A área de governança de TI faz parte do departamento das áreas de operações, porém responde de maneira independente ao vice-presidente. Esta área é responsável por acompanhar e 
direcionar as práticas aplicadas aos projetos e operações continuadas de serviços de TI (D10). Os resultados apurados são financeiros e operacionais.

O planejamento para investimentos em TI, considerando manutenções e desenvolvimentos de novos sistemas, é proposto e controlado anualmente pelo comitê de TI, tendo orçamento aprovado pelos executivos (R1).

A organização conta com uma área de segurança corporativa com 170 profissionais, que investiga e trata incidentes e estabelece políticas de segurança. Como a preocupação do negócio é com relação a sua confiabilidade, o tema de ataques e ameaças foi destacado, tanto os de origem interna, partindo de seus profissionais (R2), quanto externamente (R3).

Há estrutura de contingência a quente, que permite a continuidade imediata das operações em caso de desastre (R4). A característica de risco considerada mais grave das operações é a indisponibilidade dos serviços (R6), já que se reflete diretamente à imagem de confiabilidade que a organização precisa ter perante o mercado.

A organização investe consistentemente em inovação e tecnologia para melhorar seu desempenho, ao reduzir custos internos, e competir no mercado (R7). Contudo, o entrevistado classifica a organização como conservadora para assumir riscos, dada sua natureza de negócios. Há grande cautela desde o processo de decisão do investimento pelo comitê (R11) até o gerenciamento das mudanças (R10) para garantir que a introdução das novidades tecnológicas não interfira com o funcionamento adequado das operações.

\subsubsection{Pontos mais relevantes do caso}

Os planos de ação e gerenciamento sempre são orientados à redução de riscos. Este posicionamento é compreensível dado o mercado em que a organização está inserida.

Nota-se que as práticas de melhoria contínua estão presentes na organização. Um trabalho contratado junto a uma consultoria de negócios ajudou a estabelecer limites aceitáveis de risco para onze variáveis de controle das operações de TI. Quando as medições acompanhadas 
semanalmente atingem tais limites, necessariamente são criados e acompanhados planos de ação para seu tratamento.

Destacou-se a arquitetura de TI como diferencial de negócios. Novamente se trata de um conjunto de investimentos voltados à redução de erros operacionais, que podem ser causados pela complexidade do ambiente gerenciado. A simplificação dos processos e padronização de desenvolvimento e infraestrutura facilitam as atividades dos profissionais. Apesar da valorização das pessoas e processos, buscou-se investir na causa dos problemas medidos de retrabalho.

Foi citado pelo entrevistado que, pela natureza do negócio, a organização está sempre passando por auditorias de diferentes órgãos oficiais e regulatórios. Portanto, as práticas e processos estão em contínua revisão. Como destaque positivo apontado por estes auditores está o comitê de TI, que cumpre um importante papel de comunicação e integração entre as áreas.

\subsection{Quadro resumo das entrevistas}

Nesta seção se apresenta na Tabela 19 um quadro resumindo os principais pontos encontrados durante as entrevistas, categorizados pelos fatores de risco e desempenho especificados nesta pesquisa (segundo Tabela 3 e Tabela 4), reordenados pelas similaridades entre as respostas obtidas nas entrevistas e estabelecendo comparações nos casos encontrados.

Tabela 19 - Quadro resumo das entrevistas.

\begin{tabular}{|c|c|c|c|}
\hline & Fator & Evidências & Casos \\
\hline Risco & $\begin{array}{l}\text { Decisão } \\
\text { Investimentos } \\
\text { (contexto externo) }\end{array}$ & $\begin{array}{l}\text { A estrutura da tomada de decisões, } \\
\text { como o envolvimento do board, } \\
\text { acabou se mostrando um ponto crítico } \\
\text { ao fazer com que os líderes sejam } \\
\text { capazes de relacionar objetivos e } \\
\text { necessidades de tecnologia com } \\
\text { desempenho do negócio. }\end{array}$ & $\begin{array}{l}\text { Contraponto: } 1 \\
\text { versus } 2 .\end{array}$ \\
\hline
\end{tabular}




\begin{tabular}{|c|c|c|}
\hline $\begin{array}{l}\text { Segurança da } \\
\text { informação } \\
\text { (contextos } \\
\text { externo/interno) }\end{array}$ & 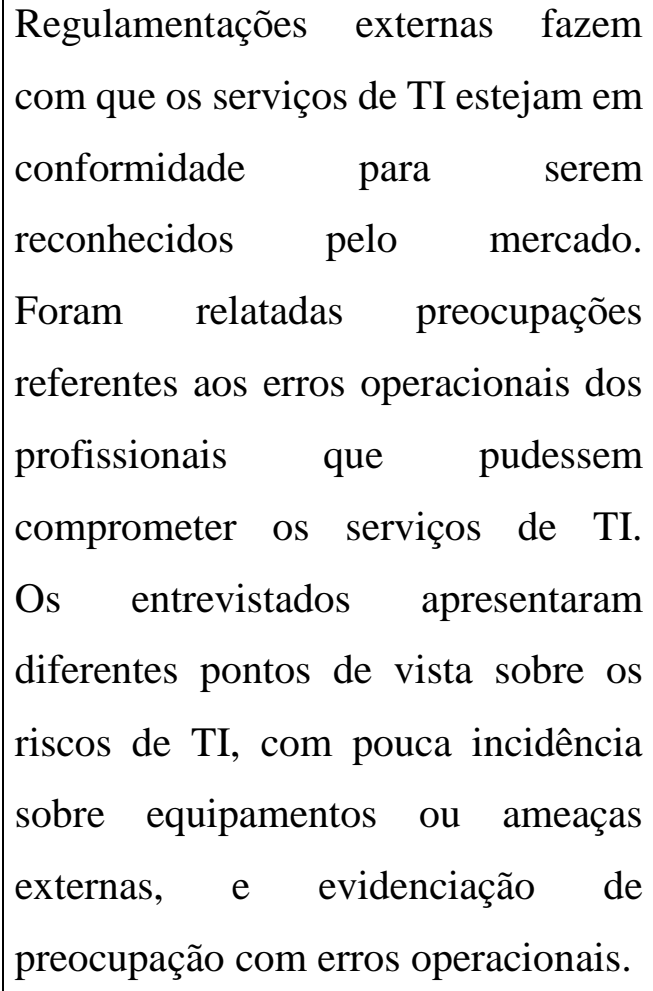 & $\begin{array}{l}\text { Contraponto: } 2 \\
\text { versus } 8 .\end{array}$ \\
\hline $\begin{array}{l}\text { Continuidade de } \\
\text { serviços (contexto } \\
\text { externo) / Riscos } \\
\text { de TI (contexto } \\
\text { externo) }\end{array}$ & $\begin{array}{l}\text { Investimentos em continuidade de } \\
\text { serviços se relacionaram com a } \\
\text { atitude perante o risco: organizações } \\
\text { mais estabelecidas e consolidadas } \\
\text { buscaram soluções de contingência e } \\
\text { as oferecem a seus clientes como } \\
\text { serviços para aumento da } \\
\text { disponibilidade e diminuição de } \\
\text { riscos. Já outras organizações não o } \\
\text { fazem por focar os investimentos e } \\
\text { esforços na conquista de novos } \\
\text { contratos. }\end{array}$ & $\begin{array}{l}\text { Contraponto: } 2 \text { e } \\
4 \text { versus } 1 \text { e } 8 .\end{array}$ \\
\hline $\begin{array}{l}\text { Atitude perante o } \\
\text { risco (contexto } \\
\text { interno) }\end{array}$ & $\begin{array}{l}\text { A atitude perante o risco depende do } \\
\text { momento pelo qual passa a } \\
\text { organização. Se precisa crescer, fica } \\
\text { mais exposta a riscos flexibilizando } \\
\text { em maior grau condições internas } \\
\text { para atender aos requisitos do cliente. } \\
\text { Se está num momento de }\end{array}$ & $\begin{array}{l}\text { Contraponto: } 2 \text {, } \\
5 \text { e } 7 \text { versus } 1,3 \\
\text { e } 6 .\end{array}$ \\
\hline
\end{tabular}




\begin{tabular}{|c|c|c|}
\hline & $\begin{array}{l}\text { estabilização e controle de resultados, } \\
\text { evita riscos buscando contratos mais } \\
\text { conservadores e menos flexíveis. }\end{array}$ & \\
\hline $\begin{array}{l}\text { Salvaguarda de } \\
\text { ativos (contexto } \\
\text { interno) }\end{array}$ & $\begin{array}{l}\text { O processo de gerenciamento de } \\
\text { configuração foi desconsiderado } \\
\text { pelos entrevistados como crítico, por } \\
\text { não apresentar diretamente resultados } \\
\text { no relacionamento com os clientes. } \\
\text { Assim sendo, o controle dos ativos } \\
\text { ficou relegado a segundo plano. }\end{array}$ & Todas. \\
\hline $\begin{array}{l}\text { Tomada de } \\
\text { decisão baseada } \\
\text { em informações } \\
\text { (contexto interno) }\end{array}$ & $\begin{array}{l}\text { Segundo a maior parte dos } \\
\text { entrevistados, o processo de tomada } \\
\text { de decisão ocorre baseado em } \\
\text { informações extraídas das métricas de } \\
\text { processos. Seus resultados auxiliam } \\
\text { no controle operacional das áreas, } \\
\text { bem como decisões estratégicas da } \\
\text { organização. Apenas uma } \\
\text { organização colocou o fato de utilizar } \\
\text { essas métricas para comparar o } \\
\text { desempenho entre diferentes áreas, } \\
\text { estimulando o compartilhamento de } \\
\text { melhores práticas. }\end{array}$ & $\begin{array}{l}\text { Prática de } \\
\text { comunicação } \\
\text { entre as áreas: } 3 \text {. }\end{array}$ \\
\hline $\begin{array}{l}\text { Gerenciamento } \\
\text { das mudanças } \\
\text { (contexto interno) }\end{array}$ & $\begin{array}{l}\text { Para gerenciar mudanças, as } \\
\text { organizações apontaram para } \\
\text { formalização de processos de controle } \\
\text { e comunicação. O principal objetivo é } \\
\text { evitar erros operacionais. A } \\
\text { maturidade destes processos varia } \\
\text { muito nas organizações, mas todas } \\
\text { reconheceram seu valor, }\end{array}$ & $\begin{array}{l}\text { Contraponto: } 2 \\
\text { versus } 6 .\end{array}$ \\
\hline
\end{tabular}




\begin{tabular}{|c|c|c|c|}
\hline & & $\begin{array}{l}\text { principalmente do ponto de vista de } \\
\text { consistência interna de entrega. }\end{array}$ & \\
\hline & \begin{tabular}{ll}
\multicolumn{2}{l}{ Conformidade } \\
com políticas \\
internas & (contexto \\
interno) &
\end{tabular} & $\begin{array}{l}\text { As regras de governança corporativa e } \\
\text { o relacionamento com as decisões do } \\
\text { board foram citados como as políticas } \\
\text { que mais impactam as necessidades } \\
\text { de conformidade de práticas dos } \\
\text { serviços de TI. Há diferenças com } \\
\text { relação a estruturas de acionistas, } \\
\text { como por exemplo o caso de uma } \\
\text { organização em que a família } \\
\text { majoritária toma decisões muito mais } \\
\text { diretas que em outras empresas cujos } \\
\text { acionistas estão no mercado. }\end{array}$ & $\begin{array}{l}\text { Contraponto: } \\
\text { organização } 3 \\
\text { versus } 1 .\end{array}$ \\
\hline & Fator & Evidências & Casos \\
\hline \multirow[t]{2}{*}{ Desempenho } & $\begin{array}{l}\text { Recursos } \\
\text { processos dos } \\
\text { parceiros } \\
\text { (contexto externo) }\end{array}$ & $\begin{array}{l}\text { Os parceiros não foram considerados } \\
\text { como elemento fundamental para } \\
\text { obter desempenho nos serviços de TI. } \\
\text { As atividades consideradas chave e } \\
\text { mais próximas do relacionamento } \\
\text { com o cliente, com entregas de maior } \\
\text { visibilidade são executadas com } \\
\text { profissionais da própria organização. }\end{array}$ & Todos. \\
\hline & $\begin{array}{l}\text { Foco nos clientes / } \\
\text { Clientes } \\
\text { satisfeitos } \\
\text { (contexto externo) }\end{array}$ & $\begin{array}{l}\text { Apontado como o principal fator de } \\
\text { desempenho, uma vez que para obter } \\
\text { exxito a organização deve entender e } \\
\text { gerenciar as expectativas referentes } \\
\text { aos requisitos de seus clientes. Porém, } \\
\text { dependendo do momento em que os } \\
\text { negócios se encontram, por exemplo a } \\
\text { necessidade de crescimento sobrepõe }\end{array}$ & $\begin{array}{l}\text { Contrapontos: } 1 \\
\text { e } 3 \text { versus } 2 \text {, } 4 \text { e } \\
7 .\end{array}$ \\
\hline
\end{tabular}




\begin{tabular}{|c|c|c|}
\hline & $\begin{array}{l}\text { a de estabilização, a atitude entre abrir } \\
\text { mão de controles e padrões para } \\
\text { atender pontualmente a necessidades } \\
\text { do cliente se ressalta. }\end{array}$ & \\
\hline $\begin{array}{l}\text { Escopo de } \\
\text { tecnologia } \\
\text { (contexto externo) }\end{array}$ & $\begin{array}{l}\text { As organizações observam o mercado } \\
\text { e as demandas de cliente para } \\
\text { estabelecer o escopo de tecnologia } \\
\text { que adotam. A busca por soluções } \\
\text { tecnológicas para a prestação de } \\
\text { serviços de TI acontece após este } \\
\text { entendimento. }\end{array}$ & Todos. \\
\hline $\begin{array}{l}\text { Competências } \\
\text { sistêmicas } \\
\text { (contexto externo) } \\
\text { / Processos } \\
\text { eficazes / Saídas } \\
\text { de qualidade } \\
\text { Arquitetura } \\
\text { (contexto interno) }\end{array}$ & $\begin{array}{l}\text { Os processos foram apontados como } \\
\text { fundamentais para estabilizar e } \\
\text { padronizar as operações de TI, em } \\
\text { busca de entregas consistentes de } \\
\text { serviços. Embora as pessoas não } \\
\text { tenham sido apontadas como grandes } \\
\text { diferenciais, a preocupação com erros } \\
\text { operacionais causados por elas está } \\
\text { fortemente marcada nas palavras dos } \\
\text { entrevistados. } \\
\text { A definição da arquitetura de TI foi } \\
\text { colocada como secundária pela maior } \\
\text { parte dos entrevistados, uma vez que } \\
\text { deve ser definida de acordo com as } \\
\text { necessidades dos clientes, e não ser o } \\
\text { principal diferencial } \\
\text { desempenho. }\end{array}$ & $\begin{array}{l}\text { Contraponto: } 3 \\
\text { versus } 6 .\end{array}$ \\
\hline
\end{tabular}




\begin{tabular}{|c|c|c|}
\hline $\begin{array}{l}\text { Outros recursos da } \\
\text { organização } \\
\text { (contexto interno) }\end{array}$ & $\begin{array}{l}\text { As decisões sobre investimentos são } \\
\text { independentes de outras áreas de } \\
\text { apoio da organização prestadora de } \\
\text { serviços de TI. }\end{array}$ & $\begin{array}{l}\text { Contraponto: } 1 \\
\text { versus } 2 .\end{array}$ \\
\hline $\begin{array}{l}\text { Conhecimento no } \\
\text { negócio de TI } \\
\text { (contexto interno) }\end{array}$ & $\begin{array}{l}\text { O gerenciamento é feito através da } \\
\text { divulgação de métricas extraídas dos } \\
\text { processos. Com esta exposição se } \\
\text { busca maior atenção de todos em suas } \\
\text { atividades, uma vez que os resultados } \\
\text { estão mais aparentes. }\end{array}$ & $\begin{array}{l}\text { Destaque nos } \\
\text { casos } 3 \text { e } 6 .\end{array}$ \\
\hline $\begin{array}{l}\text { Profissionais } \\
\text { competentes } \\
\text { (contexto interno) }\end{array}$ & 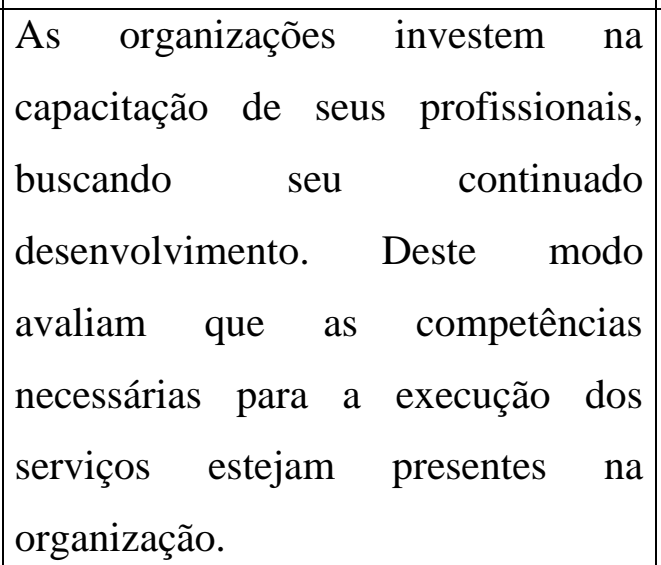 & $\begin{array}{l}\text { Todas } \\
\text { apresentaram } \\
\text { programas de } \\
\text { desenvolvimento } \\
\text { e treinamento. }\end{array}$ \\
\hline $\begin{array}{l}\text { Sistemas de } \\
\text { comunicação } \\
\text { eficazes (contexto } \\
\text { interno) }\end{array}$ & $\begin{array}{l}\text { As organizações apresentaram formas } \\
\text { de treinar e comunicar os } \\
\text { profissionais sobre os objetivos e } \\
\text { mudanças sobre os processos ligados } \\
\text { à entrega de serviços de TI. Deste } \\
\text { modo diminuem o risco de erros } \\
\text { causados por erros de execução de } \\
\text { atividades. }\end{array}$ & $\begin{array}{l}\text { Contraponto: } 1 \\
\text { versus } 4 .\end{array}$ \\
\hline $\begin{array}{l}\text { Políticas de } \\
\text { gerenciamento, } \\
\text { investimentos, } \\
\text { planos e ações } \\
\text { (contexto interno) }\end{array}$ & $\begin{array}{l}\text { A presença do board foi colocada } \\
\text { como um ponto fundamental de } \\
\text { validação e convencimento para } \\
\text { viabilizar as atividades subsequentes. }\end{array}$ & $\begin{array}{l}\text { Estruturas muito } \\
\text { variáveis. }\end{array}$ \\
\hline
\end{tabular}




\begin{tabular}{|l|l|l|l|l|} 
Definir um plano & As opiniões sobre a importância da & Contrapontos: 1 \\
estratégico de TI & utilização da norma ISO 20.000 pelas & versus 2,7 \\
(contexto interno) & $\begin{array}{l}\text { organizações diferiram em termos de } \\
\text { pontos específicos do modelo. Como } \\
\text { ponto comum, o estabelecimento de } \\
\text { uma cultura de melhoria contínua traz }\end{array}$ & versus \\
benefícios para as empresas, em \\
termos de continuamente buscarem se \\
adaptar às necessidades dinâmicas \\
dos clientes.
\end{tabular} \mid

Foram notadas algumas particularidades nos casos estudados, que mostram oportunidades de comparação entre elas, seja por similaridade ou discrepância.

No caso 8, notou-se uma organização muito voltada para o atendimento dos requisitos internos do negócio para disponibilidade, enquanto as outras seguiam uma orientação de vendas, buscando ao máximo o atendimento dos requisitos dos clientes. Nos casos 2 e 4 fícou exacerbado o foco nas demandas de clientes, em detrimento ao processo padronizado dentro da organização: aceitaram-se com maior facilidade mudanças, e consequentemente toma-se maior risco, em favor da tomada de mercado. Os casos 5 e 7, por conta da presença geográfica e tamanho das prestadoras de serviços de TI, apresentaram posturas diferentes para poder competir no mercado em que os competidores estão presentes fisicamente e aparentemente melhor posicionados para prestar os serviços. 


\section{ANÁLISE DE RESULTADOS}

A consolidação dos dados coletados nos casos estudados permite uma análise sobre cada organização de maneira individual, bem como um panorama para comparação entre as organizações brasileiras certificadas ISO 20.000.

Neste capítulo são apresentados os dados dos questionários da primeira fase, das entrevistas da segunda fase e sua análise conjunta, com pontos comuns e divergentes encontrados nas respostas das organizações.

A análise apresenta primeiramente a comparação entre os questionários da fase 1 , buscando pontos comuns entre os fatores de desempenho e risco solicitados e relacionando-os com os qualificadores das organizações. Os dados coletados na segunda fase, consolidados no quadro resumo da Tabela 19, são analisados com relação à conceituação de governança de TI apresentada na Seção 3.1, os fatores de risco e desempenho e sua relação. Como fechamento se analisam os dados em conjunto para buscar conclusões referentes às perguntas de pesquisa (Seção 1.3) e seus objetivos (Seção 1.4).

Um dos fatos que se constatou durante as entrevistas foi que a norma ISO 20.000 não se tornou um padrão amplamente usado no mercado, pois são poucas as organizações certificadas (CEBRASSE, 2014). Havia uma expectativa no final da década de 2000 que esta norma seria amplamente adotada para os serviços de TI e exigida em muitas concorrências de prestação de serviços de TI. Tal previsão não se confirmou (APM GROUP, 2013).

Pela utilização do método com entrevistas semiestruturadas, foi possível estabelecer uma comparação entre as organizações através de critérios de governança de TI para as perguntas do questionário da segunda fase. A análise foi feita através dos critérios de risco e desempenho definidos nesta pesquisa, comparando as organizações e depois observando pontos comuns e divergentes encontrados nos discursos dos entrevistados, utilizando o quadro resumo (Tabela 19). 


\subsection{Conceito de governança de TI e qualificação}

Quanto às definições de governança de TI, segundo o modelo canônico adotado nesta pesquisa, nota-se uma predominância do modelo de decisão corporativo (R1), conforme a classificação definida por Xue; Liang e Boulton (2008). Este modelo é comparável com o arquétipo federativo proposto por Weill e Ross (2004): há um comitê ou board de diretores que se encontra para tomar as decisões sobre investimentos de TI (R11) e analisar seu desempenho (D12).

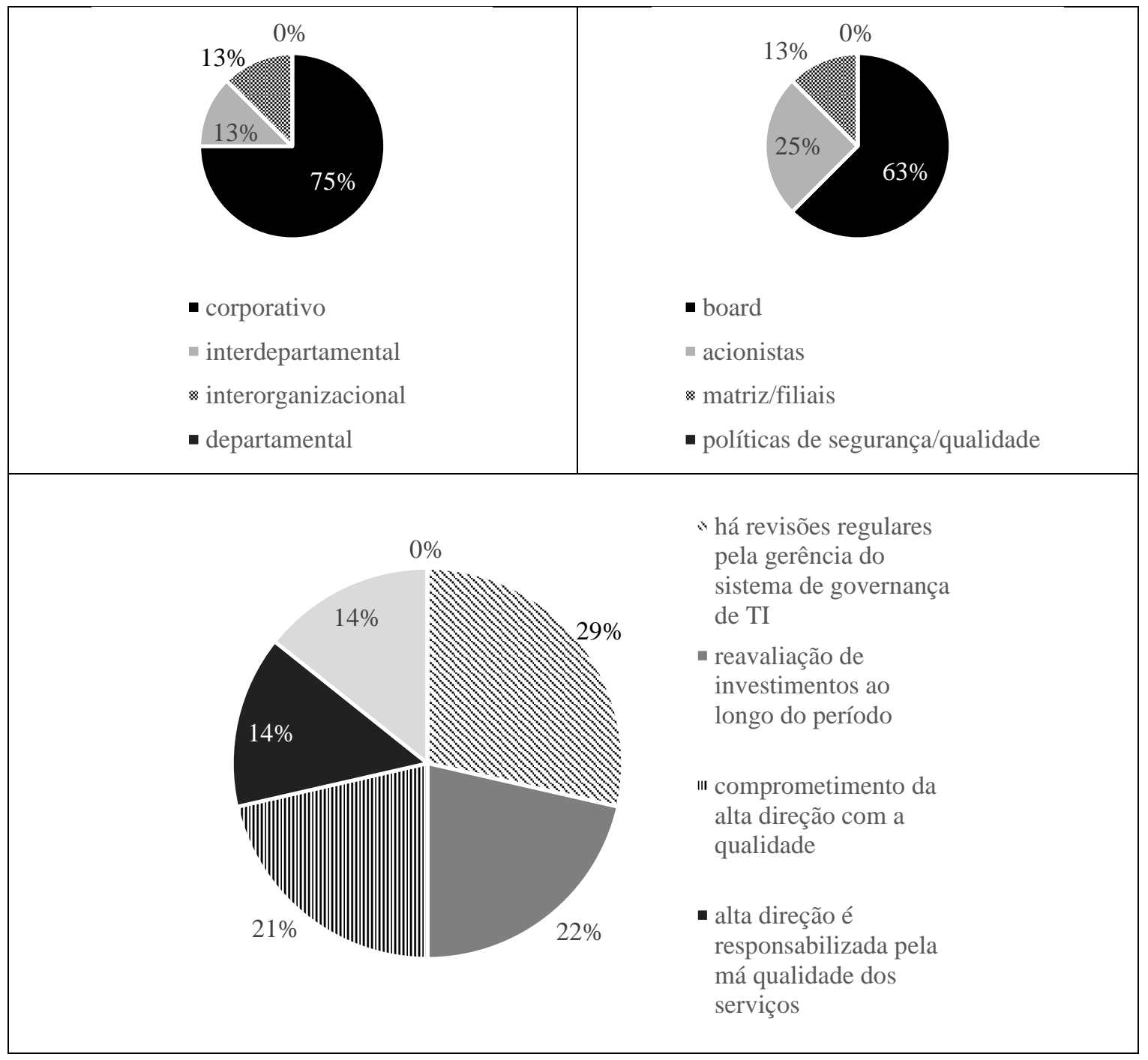

Figura 33 - Processo de decisão sobre investimentos em TI (R1) à esquerda, as regulamentações internas para decisões sobre TI (R11) e como é feito o planejamento para investimentos em TI (D12) abaixo.

Verificou-se que as relações com as outras áreas administrativas da organização se dão, na maioria das organizações entrevistadas $(87 \%)$, sobre as priorizações de negociações e recursos para objetivos de TI (D5). Isto se sobrepõe aos processos de negócio, que corrobora a estruturação de decisões conjuntas sobre os investimentos. 
Sobre a análise de dados, apresenta-se um quadro maduro em termos de formalização de processos de avaliação de métricas e desempenho dos serviços de TI (Figura 34), refletindo práticas institucionalizadas de melhoria contínua. As respostas foram consideradas segundo escala de maturidade proposta no Cobit (ISACA, 2012).

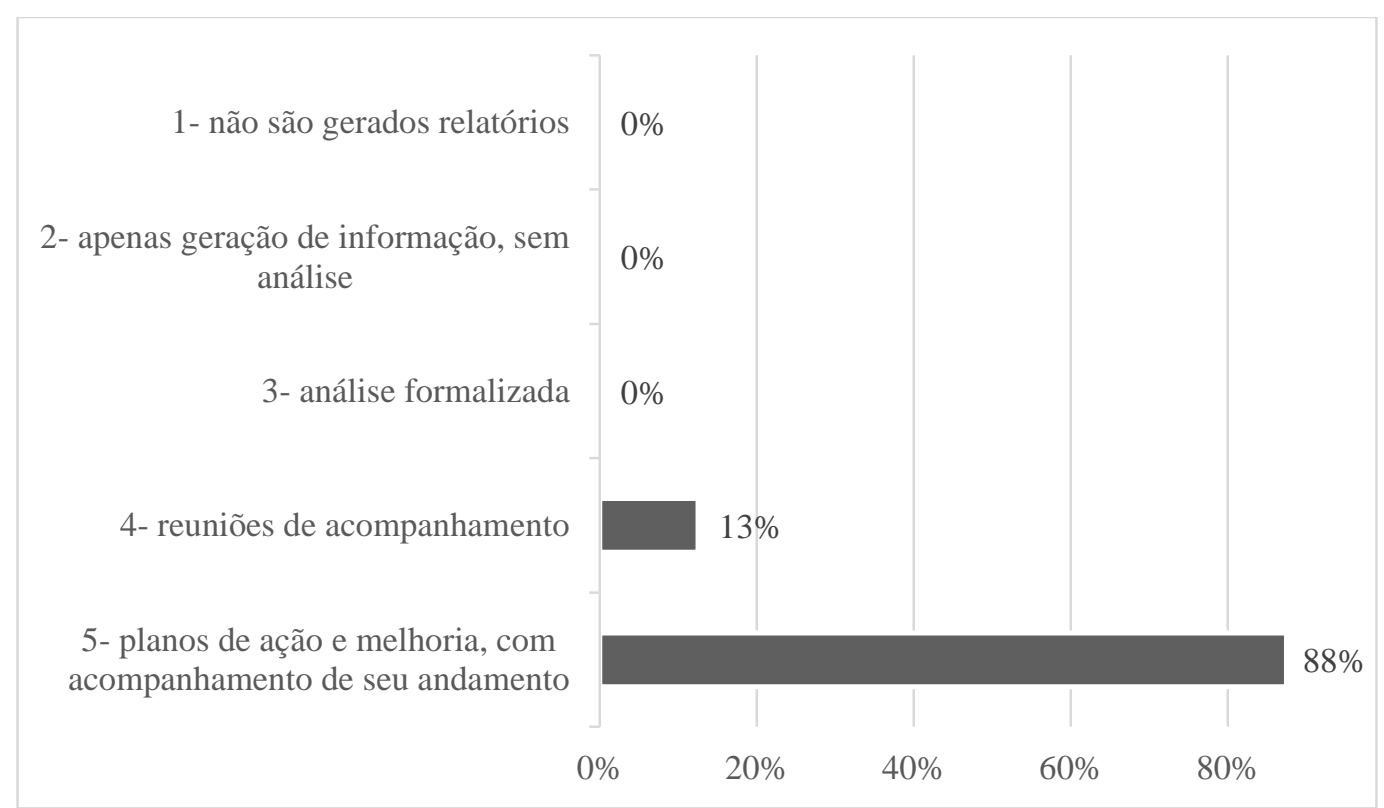

Figura 34 - Tomada de decisões: como são utilizados os relatórios gerados nos processos para análise de melhoria (R9), conforme índice de maturidade apresentado pelo Cobit (ISACA, 2012).

Em sua estruturação, apresentada na Figura 35, as organizações apontaram como definem seus portfólios de serviços de TI e seus principais diferenciais. 


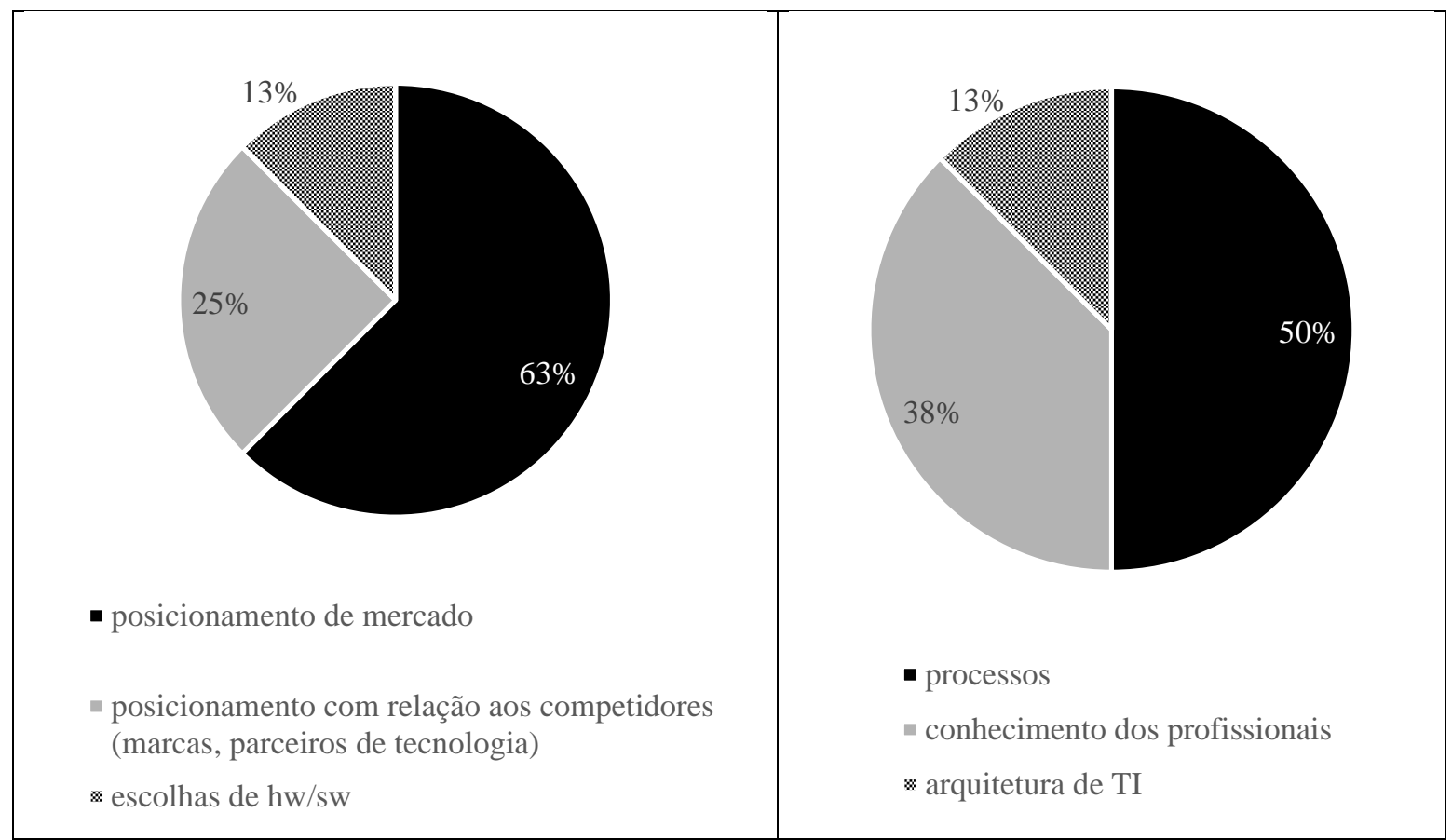

Figura 35 - Foco do portfólio de serviços de TI (D3) à esquerda, e principal fator de diferenciação da organização (D4), à direita.

Com relação à salvaguarda de ativos, 50\% das organizações utilizam controles automatizados por ferramentas e processos, enquanto a outra metade utiliza controles manuais (R8). Em termos de aquisição e manutenção da infraestrutura de TI, a arquitetura não foi apontada como diferencial mais marcante para competir no mercado (Figura 35, D4), sendo que as escolhas podem ser feitas por necessidades de configurações do parque atual, para 50\% dos entrevistados ou para a criação de novos serviços para a outra metade (D14).

O processo de gerenciamento de configuração é apontado no modelo canônico de governança de TI como essencial para os demais, porém os entrevistados apontam a necessidade de aplicálo apenas no que é útil a outros processos, como gerenciamento de incidentes e mudanças. Os motivos alegados pelos entrevistados são a falta de visibilidade de resultados imediatos diretamente associados a este processo e o seu custo, dado que precisa de cuidado contínuo e muita disciplina.

As respostas sobre a importância da utilização da norma ISO 20.000 nas organizações (D13) foram voltadas à cultura de melhoria contínua. Os controles implementados aumentam a visibilidade sobre as atividades realizadas pelos profissionais, auxiliando a tarefa dos gestores. As vantagens são apontadas especificamente sobre processos adotados que efetivamente 
apresentem resultados à organização, em termos de visibilidade direta de seus efeitos pelo cliente.

\subsection{Apreciação crítica sobre os modelos}

Ao observar os modelos apresentados neste capítulo, é proposta uma apreciação crítica sobre os mesmos.

ITIL em sua versão 3 absorveu uma série de processos que não são da estrita natureza de TI, trazendo uma visão de administração de empresas e marketing, como o gerenciamento do portfólio e o gerenciamento do conhecimento.

Esta ampliação acaba introduzindo mais conceitos a serem seguidos, mas nem sempre com o nível de detalhamento adequado, uma vez que pertencem a linhas de conhecimento distintas. Em sua tentativa de ampliar a multidisciplinaridade, ITIL conseguiu apenas ampliar sua complexidade e tornar-se ainda mais difícil no entendimento de sua adoção e implantação.

Cobit vem de um modelo estritamente voltado a auditorias de conformidade. Portanto, sua natureza é de buscar evidências nas práticas da realidade da operação em comparação à base canônica estabelecida.

Sua evolução ao longo do tempo, atualmente com a publicação da versão 5 em 2013, mostra um modelo voltado ao alinhamento das necessidades do negócio com a tecnologia da informação. Trata-se de uma melhoria no sentido de aproximar a operação de TI dos resultados da organização. Porém a grande contribuição do Cobit continua sendo os objetivos de controle que prescrevem práticas a serem seguidas para a organização de TI.

A norma ISO 20.000 nasceu de uma necessidade do mercado. Quando esta norma ainda não existia, a certificação em ISO 9.001 estava bem estabelecida no mercado, porém não era específica para o mercado das práticas de tecnologia da informação (STEVENSON; BARNES, 2002). A definição de estrutura do sistema de gerenciamento da ISO 20.000 é muito similar à da norma ISO 9.001, o que permite análises paralelas e integradas na mesma organização. Este 
foi um movimento promovido pela ISO para padronizar os sistemas de gestão em torno do ciclo de melhoria contínua PDCA, de modo a otimizar os processos de certificação e auditorias.

Como ITIL e Cobit tornaram-se modelos amplamente utilizados e as certificações dos profissionais, bem como as consultorias, estavam em alta, o mercado buscou uma maneira de identificar organizações de tecnologia da informação que estivessem buscando a adoção de melhores práticas (KESSLER, 1995; LIMA; RESENDE; HASENCLEVER, 2000; MEIRELLES, 2012; TERZIOVSKI; POWER; SOHAL, 2003).

Na metade da década dos anos 2000, certificações individuais, como ITIL Foundation e Cobit Foundation, começaram a ser exigidas em editais e concorrências privadas, como forma de medir essa adoção, mesmo que considerando apenas o número de profissionais certificados individualmente em cada uma, sem levar em conta o sistema de gestão de TI como um todo.

O conjunto de normas ISO 20.000 surge para suprir esta oportunidade no mercado, trazendo um modelo de certificação para a organização em processos de gerenciamento de serviços de TI. As concorrências e comparações entre organizações deixam de ser baseadas nos números de profissionais certificados, passando a ser sobre seus os sistemas de gestão.

Ao considerar mercados emergentes, vê-se na Figura 36 o número de organizações certificadas ISO 20.000 por continente. Em buscas realizadas até dezembro/2013, diretamente através do website sobre as certificações, mantido pelo APM Group (APM GROUP, 2013), o total de empresas é de 733 .

Foi necessário analisar a lista com um pouco mais de precisão, pois há empresas, departamentos ou projetos de um mesmo grupo registrados mais de uma vez em cada país. Foram mantidos os números para as mesmas empresas, mas com presença e certificações em diferentes países. Com este filtro, o total cai para 676, conforme ilustrado na Figura 36. A maioria destas organizações $(89 \%)$ tem como negócio-fim a prestação de serviços em tecnologia da informação. As outras organizações são, na maior parte, empresas voltadas ao mercado financeiro, corroborando a informação da Seção 1.1 sobre o grande investimento em TI deste tipo de organização. 


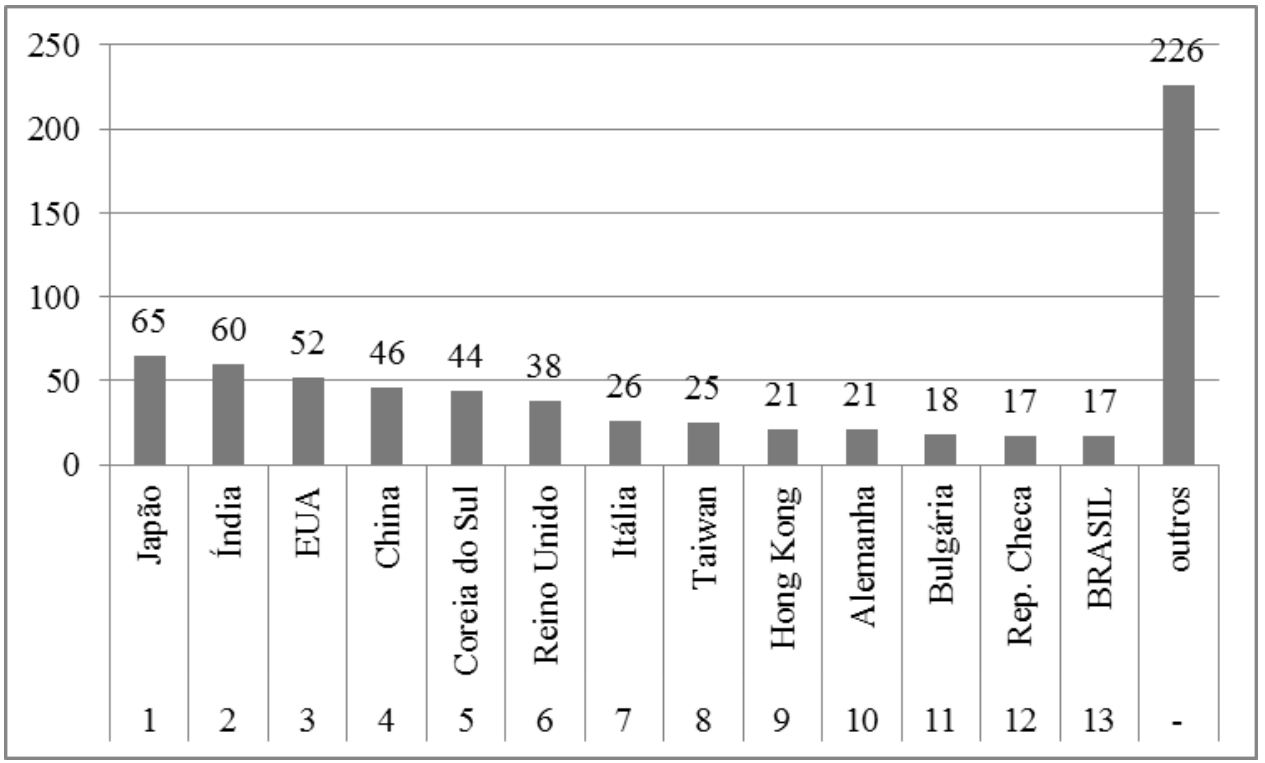

Figura 36 - Filtro das organizações certificadas ISO 20.000, até dezembro/2013. FONTE: APM Group, 2013.

Nota-se a concentração em mercados desenvolvidos e crescente interesse por mercados emergentes. Tal tendência pode ser observada de maneira similar com o que houve com certificações CMMI para organizações especializadas em desenvolvimento de software (CMMI INSTITUTE, 2013; CMMI IN MEXICO, 2012).

Como contraponto à utilização dos modelos de referência, estudos têm discutido as controvérsias entre os investimentos em certificações e adoção de modelos contra os resultados obtidos pelo negócio (CORBETT; KIRSCH, 2001; LIMA; RESENDE; HASENCLEVER, 2000; MCGUIRE; DILTS, 2008; NAVEH; MARCUS, 2005).

Ao sumarizar os objetivos e vantagens descritos pelos modelos padronizados de referência em governança de TI, encontram-se em destaque: processos, ciclo PDCA, auditoria e controle. A governança de TI é uma das maneiras de controlar a relação entre risco e desempenho. Um ponto publicado como "garantia na sua aplicação", tanto pela norma ISO 20.000 (ABNT, 2011) quanto pela ISO 38.500 (ABNT, 2009) é de aumentar o controle sobre a operação de TI, reduzindo riscos e aumentando o seu desempenho. 


\subsection{Risco}

As opiniões sobre atitudes das organizações perante os riscos foram avaliadas no questionário da primeira fase (Q18) e complementadas durante a entrevista (R7). Há a consciência sobre a mudança constante de objetivos e produtos de acordo com a competitividade do mercado. Notase porém menor busca por novas tentativas, já que são uma potencial fonte de riscos, pois podem introduzir incertezas e erros operacionais.

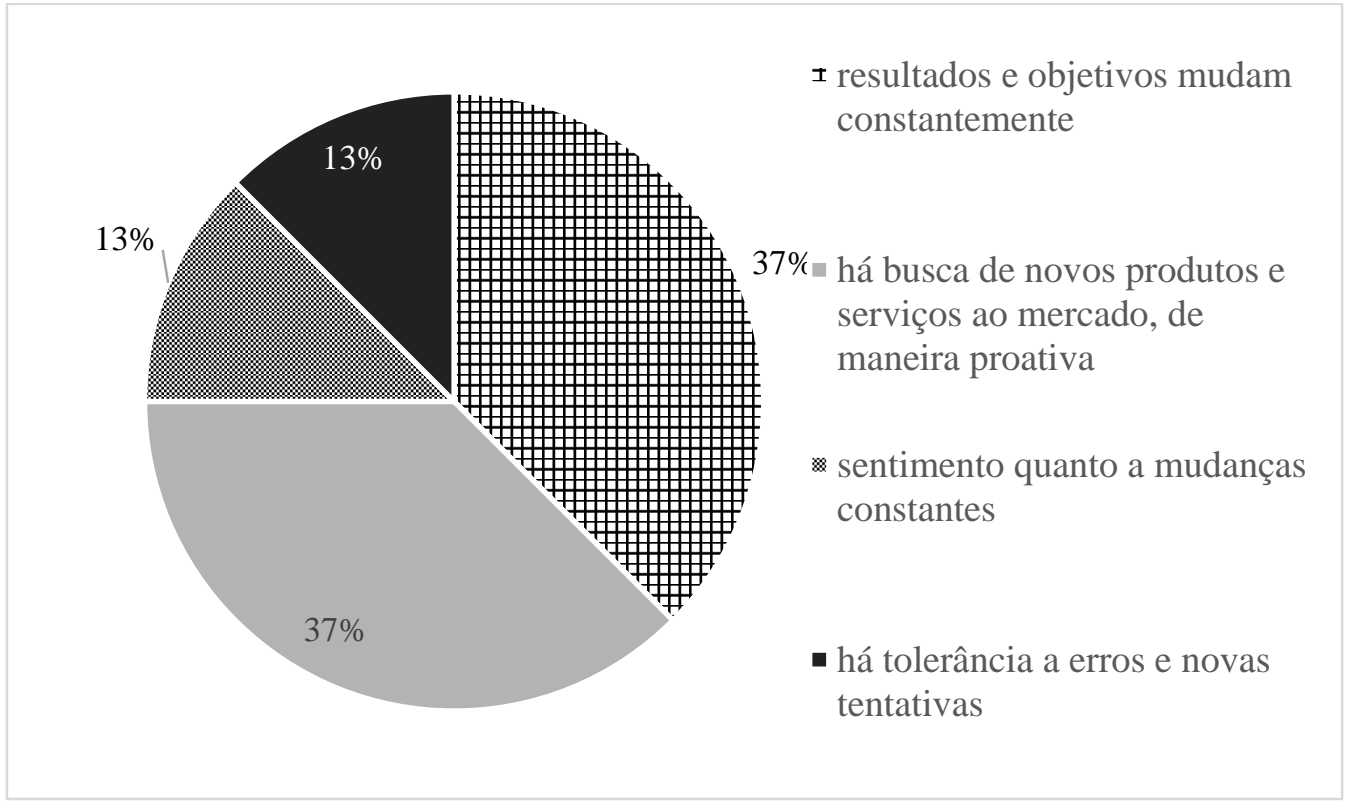

Figura 37 - Atitude da organização perante o risco (R7).

Como apresentado na Seção 2.1, os riscos foram identificados como fatores que podem comprometer negativamente o desempenho da organização. A atitude da organização perante o risco foi categorizada segundo Wilkin e Chenhall (2010) e os resultados apresentam que há um traço geral deste comportamento: aversão a riscos. É preciso notar porém que esta atitude pode variar conforme o momento econômico da organização, por exemplo quando necessita crescer e ganhar clientes (como citado pelas empresas 2 e 7). Neste ponto, admite-se maior tomada de riscos em favor do crescimento.

Os riscos foram definidos e questionados com base nos estudos de autores pesquisados (ALVES; CHEROBIM, 2004; KOBELSKY; HUNTER; RICHARDSON, 2008; WILKIN; CHENHALL, 2010). Apesar de diferentes fatores que podem ser considerados, a grande preocupação apontada pelas organizações pesquisadas são os riscos operacionais, causados por 
erros dos profissionais. Isto é endereçado pelo modelo canônico de governança ao propor padronizações e controles.

Do ponto de vista externo, algumas organizações aceitam correr riscos ao negócio, tais como oferecer novos serviços sem possuir toda a capacitação necessária, contratos genéricos com níveis de serviço não formalizados ou subjetivos, Apesar de este ser um ponto claro no modelo canônico de governança de TI: é preciso avaliar internamente a capacidade da organização de prestar um serviço antes de se comprometer com sua entrega (ABNT, 2011), sem, porém, detalhar como fazê-lo. Estes riscos podem ser ainda maiores que erros operacionais, pois podem levar ao descumprimento de contratos, rescisões e comprometimento negativo de imagem no mercado, ameaçando a sustentabilidade do negócio.

Os riscos operacionais (quando se necessita revisões de processos que estão além da capacitação da equipe) foram apontados por seis entrevistados como principais a serem mitigados, enquanto dois colocaram a disponibilidade dos serviços. Tal atitude perante o risco é confirmada ao observar as medidas adotadas para continuidade de negócios (R4): por ser um requisito obrigatório da norma ISO 20.00, metade dos entrevistados possuem plano de recuperação de desastre e a outra metade possui efetivamente um site de contingência a quente (para rápida recuperação em caso de indisponibilidade). A importância dada ao tema é relativamente grande, embora alguns entrevistados afirmem que tais medidas somente são tomadas quando há contratos com clientes dispostos a pagar por estas soluções de alta disponibilidade.

Detalharam-se os fatores operacionais apontados acima, à luz de segurança da informação (R5) que, segundo autores, contribui para o entendimento dos riscos a serem tratados pela organização (ALVES; CHEROBIM, 2004; BULCHAND-GIDUMAL; MELIÁNGONZÁLEZ, 2011) e apresentados na Figura 38. 


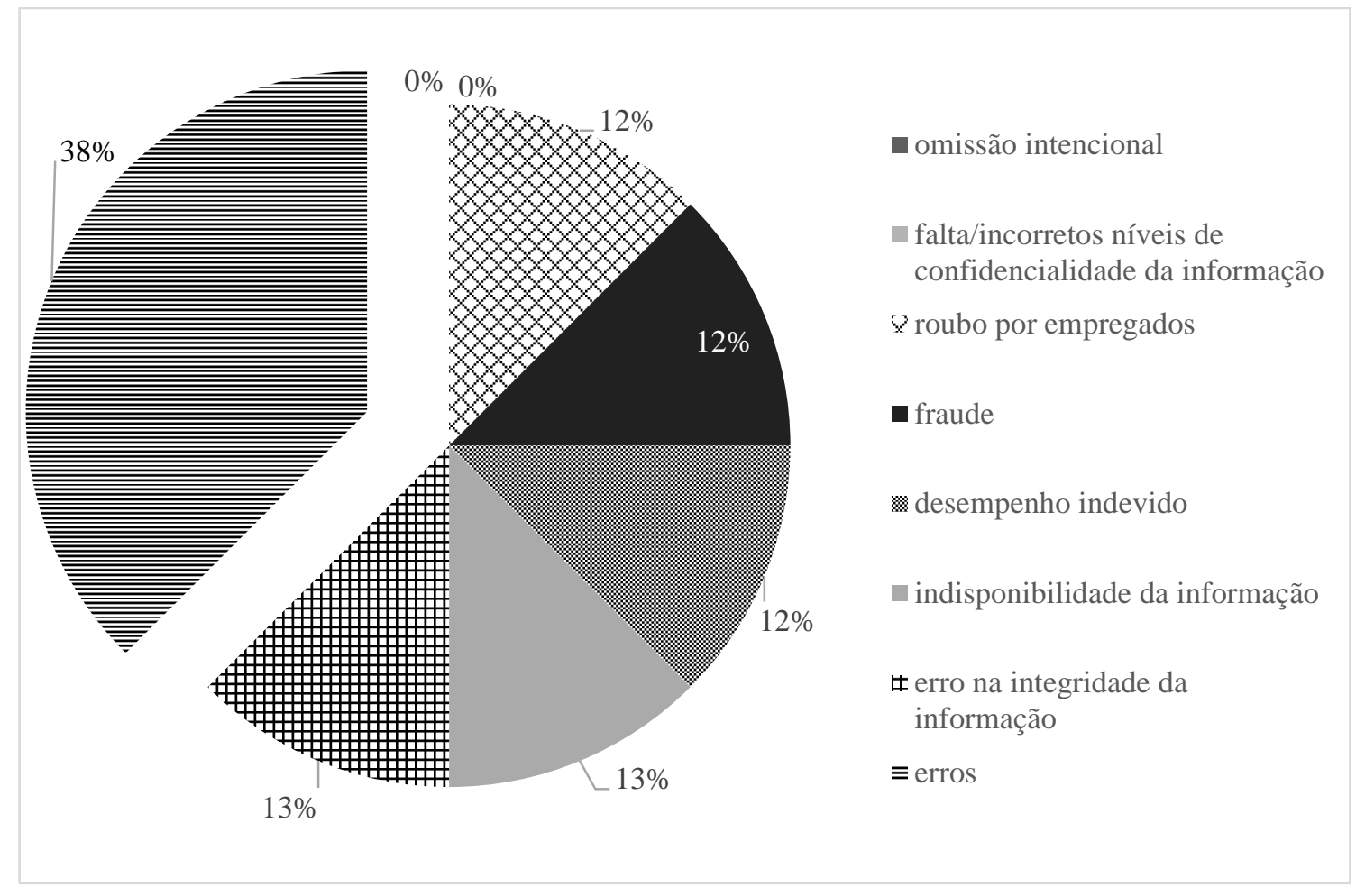

Figura 38 - Fatores internos à organização que têm maior impacto sobre segurança da informação (R5).

Os erros operacionais foram apontados como a principal preocupação dos gestores com relação à segurança. Pela definição ITIL (TAYLOR et al., 2007), confidencialidade, integridade e disponibilidade formam o tripé da segurança da informação. Pelos fatores apontados nas entrevistas, vê-se que juntos correspondem a 50\% das respostas (somando-se erro na integridade da informação, indisponibilidade, fraude e roubo por empregados).

Ainda sobre segurança da informação, observando fatores externos à organização (R3), o risco é novamente associado aos profissionais quanto a roubo e vazamento de informações sensíveis à organização. A Figura 39 apresenta estas evidências. 


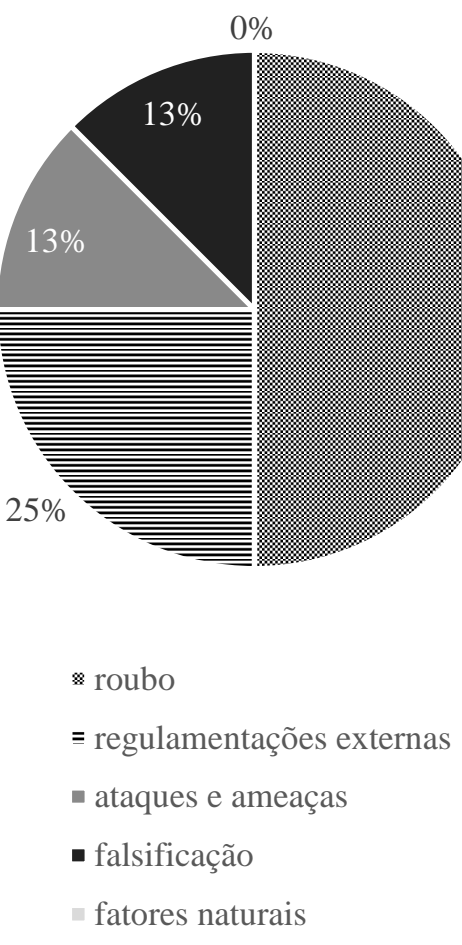

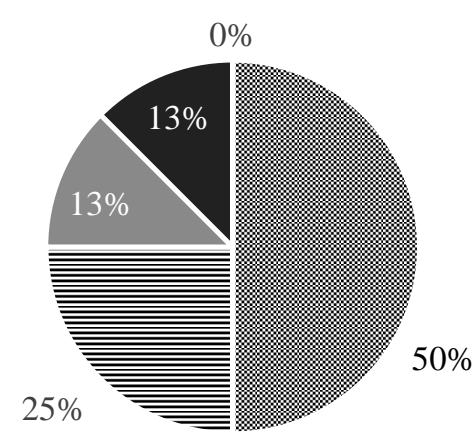

\& transferência de riscos

$=$ pressões competitivas

- pressões

institucionais/regulamentações

- ameaças e ataques

recursos externos

Figura 39 - Fatores externos à organização que têm maior impacto sobre segurança da informação (R3), à esquerda, e sobre investimentos em TI (R2), à direita.

Internamente à organização, o processo de gerenciamento de mudanças tem como objetivo comunicar as alterações aos procedimentos operacionais, minimizando riscos ocasionados por erros por não segui-los. Os dados são apresentados na Figura 40. Nota-se uma dispersão nos graus de maturidade, e apesar de 50\% dos entrevistados apresentarem evidências de alta maturidade do processo, ainda a maior causa de incidentes na operação de TI é originada por mudanças mal executadas ou mal planejadas.

5- processo definido, interage com outros procesos de governança de TI e seu...

4- processo definido e medido através de relatórios

3- processo definido, mas com erros na execução

2- há controle das mudanças, mas não formalizado nem para todas as mudanças

1- mudanças são feitas ad hoc

N/A- não há processo definido

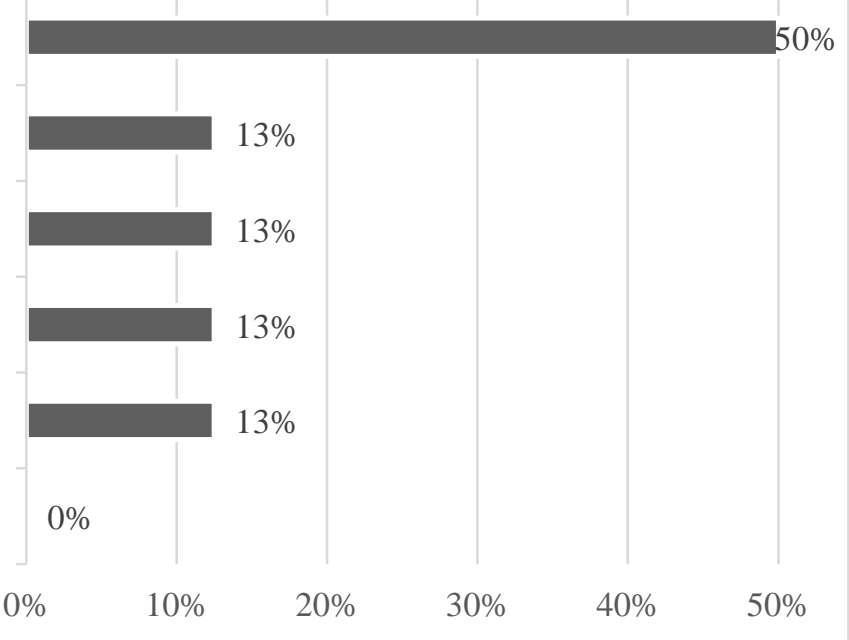

Figura 40 - Controle e comunicação das mudanças sobre processos de governança de TI (R10). 
Sobre investimentos, a Figura 39 (R2) apresenta os dados das entrevistas, em que a transferência de riscos aparece em primeiro lugar devido a problemas relacionados aos processos de terceirização de serviços de TI (PRADO; CRISTOFOLI, 2012; PRADO; CRISTOFOLI; SCHMIDT, 2012). O gerenciamento das expectativas entre o que é especificado pelo cliente, contratado e a realidade da operação é constante ao longo da vigência do contrato.

As discussões dos entrevistados como prestadores de serviços se focam em reforçar que não basta terceirizar os serviços acreditando que os problemas e riscos serão integralmente transferidos à organização prestadora. As relações de negócio e como ajudar o desempenho de suas organizações continua nas mãos do gestor de TI interno, que precisa manter as operações funcionando adequadamente além de trazer proposições de inovação. Assumir o risco de que uma organização especialista resolveria todos os problemas é uma ameaça à sustentabilidade do negócio caso a organização que os terceiriza seja muito dependente de tecnologia da informação (ALVES; RIEKSTIN, 2014; GUERRA; FISCHMANN; MACHADO FILHO, 2009; PRADO; CRISTOFOLI, 2012; PRADO; CRISTOFOLI; SCHMIDT, 2012). O conhecimento sobre a aplicação da TI sobre os processos de negócio bem como as reais necessidades e demandas das áreas de usuárias continuam sob responsabilidade do gestor de TI. Portanto precisa entender como a operação de TI apresenta os resultados que possam garantir o adequado funcionamento do dia-a-dia, mantendo o funcionamento dos serviços de TI que sustentam o negócio (GARTNER, 2014).

\subsection{Desempenho}

Pelas questões propostas, verificou-se que os entrevistados apontam a satisfação dos clientes, bem como a busca pelo entendimento de suas necessidades e seu atendimento ao longo dos contratos como desempenho dos serviços de TI. A Tabela 20 apresenta os dados entre as organizações pesquisadas. 
Tabela 20 - Questões das entrevistas que mostraram o entendimento do conceito de desempenho em relação a requisitos e satisfação dos clientes (D2, D10 e D6).

Foco nos requisitos dos clientes
(D2)
\begin{tabular}{|lr|c|}
\hline $\begin{array}{l}\text { Qualidade } \\
\text { percebida } \\
\text { clientes } \\
\text { serviços }\end{array}$ & nolos & $75 \%$ \\
\hline $\begin{array}{l}\text { Auditorias } \\
\text { qualidade } \\
\text { realizadas } \\
\text { cliente }\end{array}$ & pelo & $25 \%$ \\
\hline $\begin{array}{l}\text { Consistência } \\
\text { documentação }\end{array}$ & na & $0 \%$ \\
\hline Serviço ao cliente & $0 \%$ \\
\hline
\end{tabular}

\section{Processos evidenciar os resultados de negócio (D10)}

\begin{tabular}{|c|c|}
\hline $\begin{array}{l}\text { Objetivos } \\
\text { medidos em } \\
\text { verificações } \\
\text { são atingidos } \\
\text { em ra sua } \\
\text { maioria }\end{array}$ & $75 \%$ \\
\hline $\begin{array}{lr}\text { Serviços } & \text { são } \\
\text { medidos } & \text { com } \\
\text { relação } & \text { aos } \\
\text { requisitos } & \\
\text { iniciais } & \text { dos } \\
\text { clientes } & \\
\end{array}$ & $25 \%$ \\
\hline $\begin{array}{l}\text { Preocupação e } \\
\text { cuidados com } \\
\text { materiais e } \\
\text { equipamentos } \\
\text { relacionados à } \\
\text { entrega de } \\
\text { serviços de } \mathrm{TI}\end{array}$ & $0 \%$ \\
\hline
\end{tabular}

Principais problemas enfrentados com o gerenciamento do desempenho da TI (D6)

\begin{tabular}{|l|l|}
\hline $\begin{array}{l}\text { Relacionamento } \\
\text { com satisfação } \\
\text { do cliente }\end{array}$ & $63 \%$ \\
\hline $\begin{array}{l}\text { Avaliações do } \\
\text { board }\end{array}$ & $37 \%$ \\
\hline
\end{tabular}

Como apresentado na Seção 2.2, o desempenho é a forma de medir se a organização atinge seus objetivos. Neste contexto isto se dá através do atendimento dos requisitos dos clientes conforme declarados internamente na organização (WEILL; ROSS, 2004).

Uma das expectativas comuns entre os clientes é que a prestadora de serviços de TI assuma seus riscos operacionais. Esta discussão está intimamente relacionada com o equilíbrio entre risco e desempenho. Quanto maior desempenho, atendimento aos requisitos dos clientes e consequente maior faturamento, maior o risco - falta ou dificuldade de manter pessoal capacitado e erros operacionais. O modelo canônico de governança de TI atua neste equilíbrio ao minimizar estes riscos oferecendo padrões para os processos que podem ser executados por diferentes pessoas, com distintos níveis de experiência e treinamento (ABNT, 2011). Por outro lado, apresenta processos que permitem levantar e acompanhar os requisitos dos clientes ao longo dos contratos. 
A Figura 41 apresenta como são entendidas as demandas dos clientes. A maior preocupação das organizações é administrar as expectativas entre o que o cliente espera da prestação de serviços de TI, o que foi efetivamente contratado e as capacidades de entrega do prestador. Estas foram apontadas como as principais fontes de conflitos e dificuldades de gerenciamento ao longo da vigência dos contratos, bem como a maior preocupação para manter a continuidade e sustentabilidade do negócio de prestação de serviços de TI.

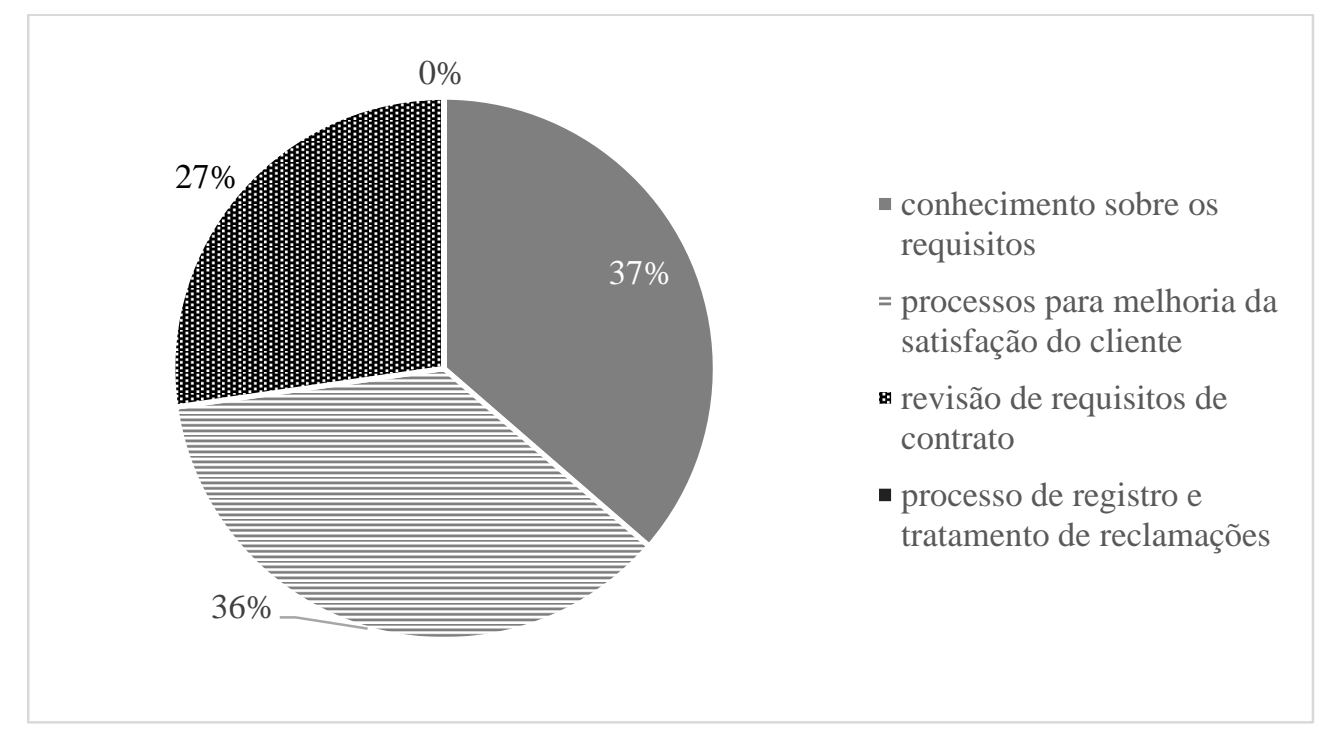

Figura 41 - Entendimento das demandas dos clientes (D7).

A prestação de serviços é continuada, diferentemente da entrega de um projeto ou um produto para os clientes. É um relacionamento que dura toda a vigência do contrato, e como tal deve ser tratado ao gerenciar as expectativas e entender os requisitos não somente no momento da venda, mas lidar em conjunto com sua dinâmica. Como apontado na Figura 35 (D4), os profissionais são considerados por três dos entrevistados como diferenciais para as organizações.

\subsection{Relação risco versus desempenho}

Com base nos dados obtidos, buscou-se explorar a relação entre desempenho e risco, conforme proposto na Figura 1. Partindo da definição de risco, apresentada na Seção 2.1, como fatores que podem impactar negativamente o desempenho da organização, procurou-se identificar tais pontos nas empresas pesquisadas e qual o papel da governança de TI neste equilíbrio. 
As organizações apontaram os processos como diferenciais competitivos (Figura 35, D4) e como poderoso instrumento de controle e prescrição de práticas. O objetivo do modelo canônico de governança de TI é, através da padronização de atividades, evitar erros operacionais (Figura 38), diminuindo a dependência do desempenho dos indivíduos e minimizando os riscos discutidos nesta seção, referentes aos profissionais padrão (como definido na Seção 2.4).

Durante o processo de mudanças, seis dos entrevistados apresentaram preocupações em comunicar as novas versões de procedimentos operacionais de modo adequado, para minimizar as chances de erro por parte dos profissionais (D9).

São apresentados pontos comuns e divergentes entre os entrevistados, de forma a consolidar os resultados das entrevistas.

Os pontos comuns encontrados nos casos estudados foram:

- Adotar mais de um modelo de referência para governança de TI;

- Adotar a norma ISO 20.000 (modelo canônico de governança de TI) como processo para consolidar práticas internas;

- Contratar a prestação de serviços de TI sendo apenas uma oportunidade ou necessidade de transferência de riscos, pelo ponto de vista dos clientes;

- Capacitar, habilitar e motivar os profissionais é uma necessidade para reduzir o risco ligado a este recurso;

- Estabelecer métricas para o gerenciamento à vista das áreas: práticas de visibilidade das ações levando a reflexão em práticas;

- Apontar processos como principal diferencial da organização;

- Considerar pouca importância aos terceiros contratados para o desempenho do negócio;

- Considerar pouca importância para o processo de gerenciamento de configuração para o desempenho do negócio;

- Considerar planos de recuperação de desastres apenas quando o cliente está disposto a contratar como parte do serviço.

Os modelos de referência trazem muitas informações relativas a boas práticas, porém em diferentes graus de detalhamento. Adotar a todos com o máximo rigor de como está no modelo se mostrou inviável como descrito pelos entrevistados. 
Sua relevância e profundidade da adoção devem ser relativizadas para cada organização, buscando adequação a sua realidade e necessidades de negócio e operação. Há uma valorização no mercado pela adoção desses modelos, percebido pelas organizações no momento de negociação de contratos e propostas com os clientes. A maioria das organizações pesquisadas mostrou que adaptaram seus processos existentes ao modelo de referência, ao invés do contrário. Isto mostra um justo interesse na melhoria contínua.

A manutenção da certificação requer a utilização do modelo canônico de governança de TI em constante comparação com as atividades que executa e os novos processos requeridos a cada novo contrato. Trata-se de uma oportunidade contínua da organização para adaptar suas práticas e processos a um referencial.

O processo de melhoria contínua torna-se assim intrínseco à organização, realizando um dos grandes benefícios previstos pela norma ISO 20.000. Os entrevistados colocam que há grande oportunidade para melhoria na maneira como a prestação de serviços de TI é contratada. Apenas formalizar níveis de serviço não basta, uma vez que muitas expectativas e detalhes de operação do dia-a-dia não são colocados em contrato, ou sequer discutidos em momento de pré-venda.

O modelo canônico de governança tem muito foco sobre os processos que possam minimizar riscos operacionais. Porém não detalha pontos sobre os contratos ou negócios: apenas a recomendação de não assumir negócios caso a organização não tenha capacidade ou recursos necessários.

A terceirização não pode ser vista apenas como transferência de riscos (PRADO; CRISTOFOLI; SCHMIDT, 2012), uma vez que os problemas e dificuldades, principalmente a integração entre TI e o negócio continuam como responsabilidade do gestor contratante.

O desempenho do negócio depende do entendimento dos requisitos das áreas usuárias pela área de TI da organização para repassá-los adequadamente a parceiros prestadores. Gerenciar as expectativas de atendimento vai além das métricas: a prestação de serviços é intrinsicamente relacionamento diário entre as pessoas das partes envolvidas. 
Capacitar os profissionais é ponto comum a todas as organizações estudadas. Há a percepção de que investir na carreira e desenvolvimento dos profissionais melhora o vínculo criado entre estes e a organização.

O maior risco apontado pelos entrevistados são os erros operacionais. Os gestores veem nos processos de governança de TI uma grande oportunidade para estabelecer controles para minimizar estes erros, dada a padronização de atividades. O efeito colateral é a pressão estabelecida sobre os profissionais (DECOSTER, 2008), que é natural ao ambiente de trabalho. Porém esta pressão pode ser exagerada em momentos específicos: como auditorias para obtenção da certificação ou a maneira como se punem erros cometidos seguindo ou não processos prescritos.

A gestão à vista das métricas, com o conhecimento e visualização de todos, influencia o comportamento dos profissionais: do ponto de vista dos gestores ampliam as trocas de práticas entre áreas, fomentando a melhoria contínua. Embora, da mesma forma que visto com os processos de governança de TI, as métricas aumentam a visibilidade das ações dos profissionais e consequentemente ampliam a reflexão em práticas, como apresentado no modelo da Figura 5, por conta da necessidade de estar em conformidade com a prescrição da organização.

A gestão por métricas introduz uma pressão sobre os profissionais para que busquem fazer suas atividades de acordo com instruções controladas. Trata-se de uma relação dúbia, pois se dá tratamento diferenciado a erros operacionais: aqueles ocorridos quando o profissional seguiu os processos são mais facilmente tolerados. Já aqueles não apoiados sobre os processos definidos pela organização, acabam sendo punidos com maior severidade.

Em consequência do risco apontado sobre os erros operacionais, as organizações investem nos processos para aumentar seu controle sobre suas operações. Dentre as organizações pesquisas, aquelas de maior porte (em número de profissionais) apontam seus processos de governança de TI como o principal diferencial.

Os processos são mantidos para estabelecer consistência de práticas e depender menos dos profissionais bem como evitar erros operacionais. Apoiados sobre as vantagens prescritas pelo modelo canônico, como diminuição de inconsistências, aumento consistente das repetições 
(ABNT, 2011), e dos outros modelos de referência como resultados previsíveis (MEIRELLES, 2012).

As atividades essenciais de atendimento ao cliente final são feitas por profissionais contratados pela organização. Muitas vezes se conta com terceiros para ter presença local em sítios do cliente onde não haja demanda suficientemente grande para ter um profissional alocado.

Apesar de pouco considerado nas entrevistas, o gerenciamento de fornecedores foi colocado como processo por um quarto dos entrevistados. Isto se deve à necessidade de terceirização de determinadas atividades e a preocupação de estabelecer critérios de seleção que possam garantir o controle sobre a qualidade e consistência das entregas desses terceiros.

O único critério estabelecido pelas organizações é referente à contratação, mas na maioria dos casos somente sobre a saúde financeira dos terceiros. Estabelecer critérios técnicos, que possam auxiliar no momento da contratação para garantir níveis de satisfação dos clientes com relação ao atendimento, seria uma evolução importante (PRADO; CRISTOFOLI, 2012).

Segundo o modelo canônico de governança de TI (Seção 3.10) o processo de gerenciamento de configuração é considerado como um dos mais importantes, uma vez que detém as informações que servem de base para os demais.

Na pesquisa este processo não foi referenciado na primeira fase (Figura 21). Para garantir o entendimento, foi esclarecido junto aos entrevistados que seu entendimento e definições do processo, verificando que estavam coerentes com o modelo canônico. Ao serem questionados durante as entrevistas, os entrevistados apontam como principais razões para o processo de gerenciamento de configuração não ser utilizado na prática:

- $\quad$ Poucos benefícios diretos: as implantações se limitam a dados utilizados por outros processos (principalmente de incidentes);

- Custos elevados: ferramentas e principalmente os procedimentos associados à manutenção da base de dados de configuração são caros. Como o benefício de diminuição de risco ou aumento de desempenho não é diretamente associado a este processo, torna-se difícil defender tais investimentos; 
- $\quad$ Procedimentos difíceis de seguir na prática: apesar de toda a automatização possível, a manutenção correta da base de dados de configuração depende fundamentalmente da adequada conduta dos profissionais quanto aos procedimentos. A base rapidamente se torna desatualizada e os benefícios, escassos (HOFSTEDE, 2012).

Apesar da disponibilidade dos serviços de TI se tratar da atividade principal da organização, sua continuidade não é avaliada de maneira proativa, ao se antecipar com investimentos a possíveis indisponibilidades.

Dentre as organizações pesquisadas, as maiores em número de profissionais, algumas possuem sistemas de continuidade de negócio. A maioria delas só realiza tais investimentos se o cliente efetivamente contrata os serviços de alta disponibilidade. Culturalmente no Brasil, admite-se este maior risco associado à falta deste tipo de investimento (HOFSTEDE, 2012).

Os pontos divergentes encontrados durante as entrevistas da segunda fase foram:

- Adotar processos padronizados apenas para ganhar escala nas áreas centralizadas (compartilhadas) da operação.

- Verificar na prática a influência da governança de TI no processo de decisão sobre investimentos na organização.

- Fomentar processos de troca de informações e práticas entre áreas diferentes, com atividades similares.

- Destacar a arquitetura de TI como diferencial.

Um dos pontos defendidos para obter desempenho na prestação de serviços de TI é investir em ganho de escala para ter operações centralizadas consistentes, com ferramentas e processos padronizados. Desta forma a organização aumenta a produtividade das equipes operacionais, reduzindo custos e promovendo trocas de práticas mais facilmente para tratamento de maior volume de solicitações do cliente e incidentes (HDI, 2013).

Porém a maioria das organizações não se mostrou preocupada com ter operações completamente isoladas e dedicadas a clientes específicos desde que a receita do contrato fosse compatível ao rendimento esperado. 
Os processos de tomada de decisão sobre os investimentos de TI são muito diversos entre as organizações entrevistadas, representando uma das características únicas para qualificá-las. Apesar do fato de que a maioria das organizações pesquisadas tende ao arquétipo federado, o sistema de governança corporativa determina os investimentos, sobretudo nas organizações menores, já que a influência da opinião dos donos é preponderante.

Somente algumas organizações citaram práticas de troca de informações formalizadas através de processos. Trata-se de uma medida simples que auxilia no aumento do desempenho e redução de custos repetitivos, intrínseca às práticas de aprendizado organizacional e melhoria contínua.

Somente uma das organizações entrevistadas destacou a arquitetura de TI como diferencial. $\mathrm{O}$ grande objetivo é mitigar riscos relacionados a erros operacionais. A complexidade do ambiente gerenciado de TI estava diretamente relacionada aos índices de retrabalho medidos pelas áreas. Investir em componentização trouxe benefícios ao simplificar o ambiente.

A Figura 42 mostra o modelo de pesquisa proposto pelo autor, a partir da análise no contexto das organizações prestadoras de serviços de TI, certificadas ISO 20.000.

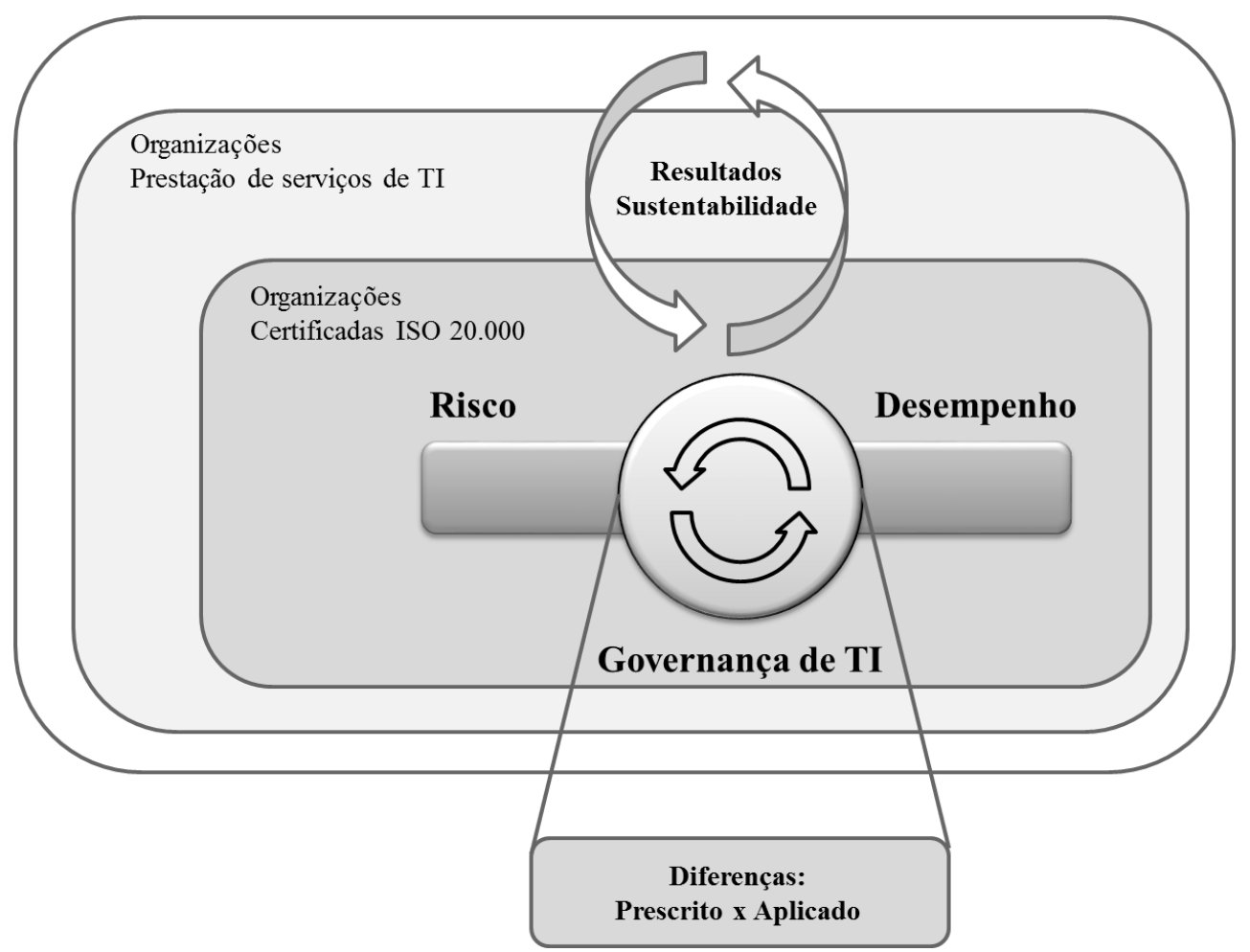

Figura 42 - Modelo de pesquisa proposto pelo autor. 


\subsection{Consolidação}

Levando em conta os aspectos discutidos, a Figura 43 representa a tentativa de equacionamento entre risco versus desempenho, sendo os processos como a chave de quanto controle é exercido pela organização.

Ao se aplicar maior controle através dos processos de governança de TI, os riscos são mitigados. Porém o desempenho acaba sendo freado, já que a primeira orientação da organização é evitar riscos e a busca de resultados fica comprometida quando necessário criar alternativas e tomar decisões diferentes.

Do mesmo modo, com menos controles presentes, a organização pode aumentar suas oportunidades para obter desempenho nos negócios. Por outro lado, os riscos aumentam e trazem mais ameaças à organização.

O ponto ótimo de controle, ou o quanto se aplicam os processos de governança de TI, depende da postura da organização perante aos riscos e o quanto ela necessita de resultados de acordo com seu momento no mercado.

Para consolidar os resultados em torno da relação entre risco versus desempenho em governança de TI, é apresentada a Figura 43. 


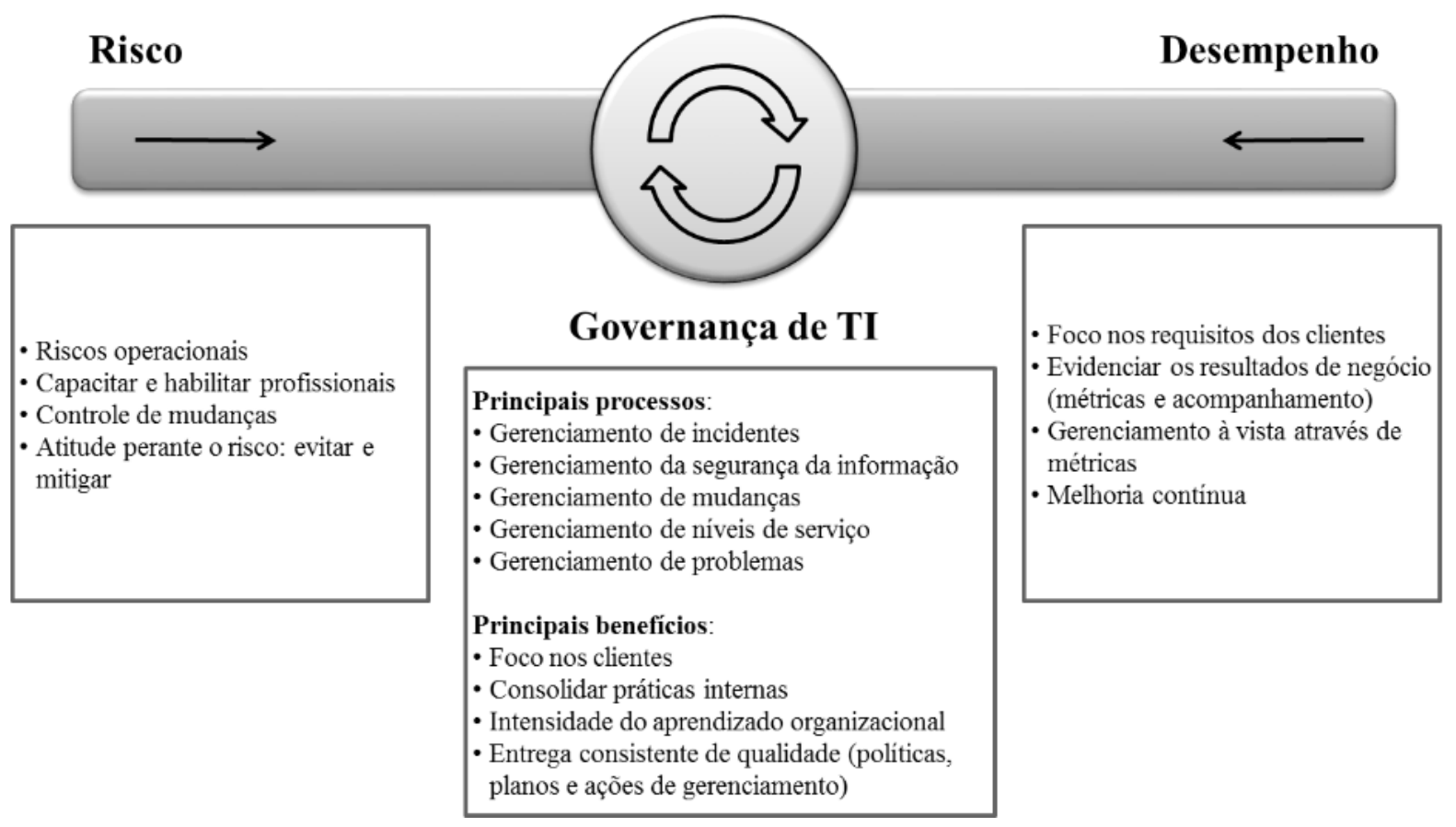

Figura 43 - Consolidação de resultados da relação risco versus desempenho em governança de $\mathbf{T I}$. 


\section{CONCLUSÕES}

Neste capítulo são apresentadas as conclusões do estudo, retomando o problema de pesquisa apresentado na Seção 1.3.

Pontos sobre o método de pesquisa utilizado são avaliados, assim como referências aos modelos conceituais utilizados como referência, sendo sugeridos para estudo futuro temas encontrados durante a coleta de dados e análises, que não foram aprofundados nesta pesquisa.

A pesquisa foi realizada utilizando a norma ISO 20.000 como modelo canônico de governança de TI. Esta é o referencial comum para as organizações pesquisadas, pois todas são certificadas por esta norma. Os modelos padronizados de governança de TI Cobit e ITIL foram utilizados para a criação dos instrumentos de pesquisa pois são os mais aplicados nas organizações, segundo Figura 6. O PMBoK foi bastante citado, porém não recebeu foco nesta pesquisa por não tratar de serviços continuados com os clientes como nos abordados pelo modelo canônico escolhido.

\subsection{Avaliação dos objetivos}

Retomando a pergunta principal desta pesquisa, conclui-se que os modelos de referência de governança de TI não são utilizados conforme originalmente prescritos em organizações cujo negócio-fim é tecnologia da informação.

$\mathrm{O}$ atendimento aos requisitos do cliente foi o fator que apareceu com maior destaque para que os processos não fossem aplicados conforme prescritos no modelo canônico. O foco dos gestores está em realizar as vendas e manter os clientes satisfeitos. Obter desempenho apareceu em maior destaque nas organizações pesquisadas, com o objetivo de manter os negócios da empresa. Os riscos a serem tratados através de controles de processos se voltam àqueles relacionados a erros operacionais dos profissionais. Exemplificando com o caso 6, o gestor entrevistado cita que "é possível aplicar processos para aumentar o desempenho, uma vez que posso melhorar como as atividades são feitas”. No exemplo do caso 8, a orientação por controle 
e minimização de risco é mais clara por ser uma área de TI interna: "não posso deixar os sistemas do negócio sem funcionar: perdemos dinheiro e credibilidade no mercado".

Os processos que foram mais destacados como relevantes na operação de TI (Figura 21) são aqueles relacionados diretamente aos resultados entregues e percebidos pelos clientes. Gerenciamento de incidentes e requisições e gerenciamento de mudanças refletem diretamente atendimentos a usuários finais dos serviços de TI. Gerenciamento de segurança da informação apareceu em segundo lugar, com forte viés a possíveis problemas causados por falhas dos profissionais envolvidos nas atividades que possam impactar negativamente os clientes.

Por outro lado, os processos que não tiveram destaque poderiam ser revistos em versões futuras do modelo canônico de governança de TI. Entender a utilidade relativa e importância dos processos é parte da evolução da maturidade dos modelos que ajudam a definir os serviços desta rede formada pelas organizações permeada pela prestação de serviços de TI. Por exemplo, o processo de Gerenciamento de Configurações tem destaque no modelo canônico por servir de base de informações aos demais, porém obteve baixa adesão por ter baixa percepção de valor de entrega ao cliente.

Do ponto de vista do administrador da organização prestadora de serviços de TI, é preciso equilibrar custo e benefício ao alocar os recursos limitados que possui para buscar o aumento de desempenho e redução de riscos de seu negócio. Apesar dos modelos de referência de governança de TI e do modelo canônico prescreverem os processos, deixam muito em aberto a decisão sobre a adoção dos mesmos, seja em relação à ordem ou grau de profundidade de sua implantação. O modelo canônico apresenta os processos de maneira linear, sem outras considerações sobre importância relativa. O modelo é muito focado em risco, voltando as práticas de governança a mitigá-los e controlá-los. O desempenho, que faz parte desta equação (Figura 43) fica em segundo plano.

Com base na análise conjunta dos casos, apresentada na Seção Erro! Fonte de referência não encontrada. sobre os fatores de risco e desempenho, foram destacados fatores que contribuem negativa e positivamente para a adoção das práticas de governança de TI como especificadas no modelo canônico encontrados. 
Os fatores encontrados que contribuem negativamente para a adoção das práticas de governança de TI como especificadas no modelo canônico foram:

- Orientação ao atendimento de necessidades dos clientes;

- Formato da decisão sobre os investimentos de TI.

O primeiro dos fatores que contribuem negativamente para a adoção das práticas, fazendo com que o modelo canônico não seja aplicado na íntegra na operação das organizações, é sua orientação ao atendimento de necessidades dos clientes. O claro foco das organizações estudadas é atender aos requisitos de seus clientes. Tal fator é apresentado pelo modelo canônico, porém altera, na prática, como os modelos de referência são aplicados pelas mesmas.

Ao atender requisitos específicos dos clientes, os processos devem ser diferenciados. Nos casos em que há estruturas centralizadas, nota-se consistência e de ganho operacional por compartilhamento de recursos. Porém, um exemplo citado por alguns entrevistados é possuir operações descentralizadas, dedicadas a alguns clientes, que passam a ter processos exclusivos para atender a demandas específicas. Isso cria uma diferenciação dos processos que precisa ser administrado internamente, em termos de recursos e investimentos.

Na disposição do cliente de transferir riscos da operação de TI para o prestador de serviços, a busca pelo desempenho é preponderante, bem como o consequente direcionamento de todas as atividades para atingir tal fim. Desta maneira, há maior investimento - de tempo, profissionais e ferramentas - para os processos do modelo canônico que trazem benefícios imediatos à operação.

Isto leva a uma adoção parcial do modelo canônico de governança de TI ou da utilização não linear de vários modelos de referência. Por exemplo: a adoção de processos com maior rigidez e profundidade apenas nas áreas que prestam serviços de TI de modo central, ao compartilhar recursos entre distintos clientes. Enquanto as operações mais próximas dos clientes possuem uma flexibilidade muito maior.

As decisões são tomadas em sua maioria através dos comitês de gestão. Tais investimentos são priorizados de acordo com as necessidades de manutenção dos negócios e, muitas vezes, voltadas a requisitos específicos de cliente, ao invés de práticas de melhoria contínua. 
Outro fator de contribuição negativa é o formato da decisão sobre os investimentos de TI. Com os diferentes arranjos para a tomada de decisão sobre estes, a estrutura de poder da organização influencia seu comportamento e o equilíbrio na relação entre risco e desempenho. Mesmo quando há controle direto vindo da alta administração, como amplamente verificado nos casos estudados, há diferenças nos objetivos da aplicação dos processos no dia-a-dia das operações de TI. Busca-se a adoção mais rigorosa de processos que tragam algum indicador ou benefício mais aparente quanto à entrega dos serviços aos clientes.

Os fatores encontrados que contribuem positivamente para a adoção das práticas de governança de TI como especificadas no modelo canônico foram:

- $\quad$ Associação dos riscos aos negócios e operações de TI aos erros causados pelas pessoas;

- Melhoria contínua;

- $\quad$ Controle sobre as mudanças na operação de TI.

O principal fator que contribui positivamente para a adoção das práticas, fazendo com que o modelo canônico de governança de TI ganhe importância para as organizações e seja aplicado conforme prescrito, é a associação dos riscos aos negócios e operações de TI aos erros causados pelas pessoas. Os principais riscos apontados nos casos estudados têm a ver com pessoas. Sejam erros na execução de suas atividades, ou descumprimento de atividades prescritas, há a preocupação dos gestores sobre possíveis impactos no desempenho dos serviços de TI. A grande maioria dos casos estudados apontaram processos e pessoas como os diferenciais competitivos da organização (Figura 35). Tal preocupação com os erros dos profissionais leva a investimentos em educação e treinamentos, bem como o estabelecimento de métricas de controle, embora todas as organizações pesquisadas façam tais investimentos citando a prática de melhoria contínua como principal motivador.

A principal causa apontada entre as organizações pesquisadas dos riscos são erros operacionais causados pelas pessoas. A gestão por processos, com base em um modelo canônico de governança de TI, é um meio de padronizar atividades e direcionar o comportamento dos profissionais. Ao estabelecer os processos e métricas, a organização demonstra sua pressão de coerção da organização sobre as pessoas. 
Outro fator que contribui positivamente para a adoção do modelo canônico é a cultura de melhoria contínua: tais práticas são difundidas nas organizações estudadas. O direcionamento para buscar a atualização das práticas de gerenciamento de TI foi identificado em todas as organizações estudadas. Notou-se que a cultura da melhoria contínua não é causada pela adoção do modelo canônico, mas sim que organizações que a possuem buscam aprimorar internamente seus processos e buscar modelos externos de referência que contribuem com esta atividade.

Tal preocupação com a melhoria contínua se mostrou na busca de modelos próprios de governança de TI, ao absorver diferentes referências dos modelos padronizados. O principal objetivo é adequar os processos à realidade da organização, levando em conta custo-benefício. Esta relação deve ser considerada quando o administrador decide investir em diferentes modelos, certificações e consultorias, já que o consumo de recursos humanos e financeiros é intenso. $\mathrm{O}$ administrador deve direcionar adequadamente os esforços para estabelecer a prática adequada a seu negócio, ou à dependência do mesmo com relação à tecnologia da informação. Assim é possível dar vazão às idiossincrasias da organização, que formam seus diferenciais competitivos.

As organizações pesquisadas demonstram práticas continuadas voltadas à melhoria de seus processos e resultados. Este desenvolvimento é o principal benefício apresentado pelo modelo canônico de governança de TI e mostra a preocupação dos profissionais da organização por sempre encontrarem meios de executar melhor suas atividades. Isto também leva à utilização de diferentes modelos de referência de governança, buscando extrair de cada um o que traz maior utilidade aos processos da organização, para a relação entre risco e desempenho.

O controle sobre as mudanças na operação de TI contribui positivamente porque os processos foram apontados como instrumentos de controle de práticas, ou nas palavras de um dos gestores entrevistados: "um modo de proteção aos profissionais, uma vez que seguindo os processos podem errar dentro do admitido pela organização". Para estabelecer estes controles sobre os profissionais, o modelo canônico de governança apresenta requisitos a serem exigidos e métricas que podem ser aplicadas à operação de TI.

Gerenciar as mudanças auxilia na prevenção de perdas ocasionadas por erros operacionais, apontados acima. É um processo que pode ser visto como uma proteção ao profissional, que na eventualidade de cometer um erro embasado pelo processo, tem uma justificativa aceita pela 
organização, pelas palavras de um dos entrevistados. Por outro lado, é um forte instrumento dos gestores para dar visibilidade às atividades operacionais, padronizá-las e aumentar o controle sobre os profissionais.

O equacionamento entre risco e desempenho passa pelos fatores citados acima. Pode-se analisar sua influência positiva ou negativa sobre esta relação ao retomar as definições apresentadas no Capítulo 0.

Riscos, conforme Seção 2.1, são definidos como o "impacto negativo do exercício de uma vulnerabilidade, considerando tanto a probabilidade quanto o impacto de sua ocorrência" (NIST, 2001). Nos dados coletados notou-se a associação direta destes riscos às pessoas que trabalham na organização. Os processos de governança de TI são utilizados para prescrever práticas requeridas pela organização, com o objetivo de aumentar o controle sobre os processos.

Desempenho, como definido na Seção 2.2, é a forma de medir se uma organização atingiu seus objetivos e é capaz de se sustentar como negócio (MAXIMIANO, 2008), sendo avaliado através de indicadores que estejam de acordo com os objetivos de negócio da organização (KOTLER; CASLIONE, 2009). Estas métricas dão visibilidade a diferentes níveis na organização, desde a operação à alta administração, de como os processos de governança de TI são seguidos. A prescrição das práticas, em conjunto com os indicadores, exerce pressão sobre os profissionais, direcionando seu comportamento para conformidade de práticas (Figura 4).

A principal motivação das organizações estudadas para se sustentarem como negócio é o atendimento dos requisitos de seus clientes, mesmo que isto reflita na flexibilização na aplicação dos processos de governança de TI.

A adoção do modelo canônico de governança de TI depende da noção da utilidade aparente dos processos: de acordo com as necessidades específicas de cada organização, que pode variar com seu momento financeiro, estratégia de crescimento, postura dos acionistas, tamanho, posicionamento - tanto geográfico quanto de postura de negócios - contra seus concorrentes e perante mercado. A relação entre risco e desempenho varia portanto, e pode ser ajustada utilizando o controle da governança de TI, conforme apresentado no modelo conceitual da Figura 43, preservando as características únicas da organização. 


\subsection{Avaliação conceitual}

Da perspectiva de administração, busca-se equilibrar risco e desempenho, focando os investimentos em atividades que possam trazer resultados adequados. O gestor deve buscar e implementar processos do modelo canônico de governança de TI de acordo com a necessidade específica do negócio de sua organização. Isto se mostrou em Figura 2, Figura 6, e Figura 13. A aplicação de diferentes modelos nas organizações e processos que não são considerados importantes mostram uma oportunidade de melhoria nos modelos de referência.

A certificação ISO 20.000 é apontada como um diferencial pelas organizações que a obtiveram (conforme Seção 7.4), porém a diferença apontada na importância relativa dos diferentes processos presentes na norma e as discrepâncias em como são aplicados na prática indicam oportunidade de melhoria no modelo.

Com sua adoção, é possível obter uma linguagem comum dentro da organização sobre os processos utilizados na governança de TI, facilitando a tradução dos objetivos de negócio no que se deve priorizar nas diferentes esferas da empresa. $\mathrm{O}$ processo de desenvolvimento e melhoria contínua leva a organização a um estado permanente de atenção e protagonismo perante as situações operacionais e de mercado às quais está sujeita.

Externamente também há efeitos positivos, uma vez que o mercado pode comparar os prestadores de serviço de TI que mais se adequam a suas necessidades, por exemplo ao observar a conformidade ou maturidade dos processos de governança de TI. A organização que consome serviços de tecnologia da informação tem parâmetros objetivos para comparar os modelos de entrega de potenciais fornecedores, fazendo com que sua decisão seja mais assertiva.

Entre as organizações prestadoras de TI pode haver comparação direta e estudos de competitividade, usando o modelo canônico como base. A organização prestadora de serviços de TI pode entender como se posicionar no mercado e refinar suas estratégias, tendo mais insumos para suas decisões quanto à relação entre desempenho e risco. Em práticas mais avançadas, é possível criar fóruns para troca de práticas, geração de indicadores comuns e que enriquecem o modelo canônico, a literatura nacional sobre o tema e estabelece uma base de 
conhecimento para a indústria brasileira de TI que pode ser compartilhada nacional e internacionalmente.

Desta maneira é possível observar o ecossistema de organizações consumidoras e prestadoras de serviços de TI: o modelo canônico de governança de TI se apresenta como um parâmetro fundamental para a viabilidade e melhoria contínua desta rede, porque fornece uma base independente de comparação e informação para ambos os lados.

A atuação do gestor, portanto, não é uma aplicação linear dos processos definidos pelos modelos de referência de governança de TI, mas sim a utilização daqueles mais relevantes para o negócio. O momento de negócios e tamanho da organização são fatores a serem considerados na diferenciação que se reflete nos processos.

O aumento de escopo dos modelos de referência de governança de TI, como por exemplo ITIL de sua versão dois para a três (conforme apresentado na Seção 3.5), acaba incluindo uma série de processos que não serão todos aplicados. O que aparenta ser um benefício ao buscar um modelo que abarque os diferentes aspectos da governança de TI, dificulta a tomada de decisão sobre a adoção pelo gestor da organização: as variáveis por onde começar e dos níveis de detalhamento com que cada um será implantado são mais complexas.

A busca de um modelo ideal faz parte do amadurecimento da indústria de tecnologia de informação e da história das organizações prestadoras de serviços de TI. Trata-se de uma indústria dinâmica e em evolução, mas relativamente jovem, com pouco mais de 50 anos. Esta visão crítica sobre os modelos e sua constante evolução é necessária, já que se conclui que ter modelo de referência como parâmetro de comparação desta indústria é fundamental.

As decisões dos gestores com relação a adoção de modelos de referência de governança de TI levam a um processo custoso para a organização, como relatado nos casos estudados. A implantação dos requisitos não são investimentos pontuais, pois é preciso manter as práticas de melhoria contínua. Também podem ser incluídos nestes cálculos treinamentos e consultorias externas contratadas para qualificar os profissionais da organização e auxiliar nestes trabalhos, ao aportar referências de melhores práticas para trazer parte do desenvolvimento já feito. Apesar disto, a organização precisa se apropriar destes conhecimentos para que passe a fazer parte de seu dia-a-dia e, de fato, seja incorporado às práticas. 
Dado o grau de especificação dos requisitos, a adoção pelas organizações pode variar muito, tornando esta análise complexa e ilusória. É necessário entrar em muitos detalhes para se estabelecer não somente a comparação entre as organizações prestadoras de serviços de TI, mas também qual modelo seria mais adequado para a empresa que os contrata, buscando melhor alinhamento de expectativas e relacionamento saudável durante a vigência do contrato. Dados estes graus de liberdade, torna-se necessário revisar periodicamente a aderência da organização a este referencial, tais como os ciclos de auditoria interna e externa.

A adoção do modelo levaria ao estabelecimento de controles que precisam ser dinâmicos o suficiente para atenderem às necessidades e às particularidades do negócio da organização. Por exemplo, no caso 8 foram notadas as preocupações do gestor com o cliente interno. Porém as preocupações demonstradas com riscos relacionados a erros operacionais levam o uso dos modelos ao estabelecimento de controles que acabam minando esta flexibilidade. O modelo canônico precisa levar em conta esta necessidade de adaptação à realidade das organizações em versões futuras. A relação, portanto, deve ser encontrada individualmente pelas organizações, a fim de atender a seu momento e objetivos de negócio, equilibrando a relação entre risco e desempenho (Figura 43).

Compreender a importância de uma certificação, baseada no modelo canônico de governança de TI, para posicionar sua organização no ecossistema de tecnologia da informação é papel fundamental do gestor no equilíbrio do custo-benefício destes investimentos, competitividade no mercado e sustentabilidade do negócio de sua organização. É fundamental que este leve em conta as necessidades específicas e próprias à organização que administra, para equacionar de maneira adequada a relação risco versus desempenho ao aplicar práticas de governança de TI.

\subsection{Avaliação do método de pesquisa}

Através da aplicação do método proposto por Webster e Watson (2002), conforme Figura 11, foi possível desenvolver referenciais baseados em literatura para construir os instrumentos de pesquisa, bem como a estruturação da análise de dados. Ao ser combinado com o método de estudo de casos proposto por Yin (2009), houve um enriquecimento dos dados obtidos em cada caso, mas principalmente em sua comparação. 
Definir o questionário e o roteiro das entrevistas com base nas referências bibliográficas, bem como as suas possíveis respostas, facilitou a coleta dos dados, ao garantir que se colhessem as mesmas informações de fontes diferentes. A análise de dados foi beneficiada também, uma vez que desta forma foi mais fácil comparar as respostas entre as organizações, como resumido na Tabela 19.

Poderiam ter sido realizadas mais entrevistas na mesma organização para cruzar informações, evitando visões com vieses. Foi possível na maior parte dos casos entrevistar gestores voltados às atividades de negócio, e não responsáveis diretos pelos processos de governança de TI. Desta maneira foi possível obter maior independência sobre o efeito e prática dos processos e não somente seu desenvolvimento teórico para publicação e auditorias internas.

Inicialmente se idealizou a primeira fase da coleta de dados aplicada a todas as organizações brasileiras certificadas ISO 20.000, com posterior aprofundamento com a segunda fase somente para algumas que se dispusessem a colaborar. Porém isto se mostrou inviável, uma vez que algumas organizações se recusaram a responder à pesquisa, baseadas em suas políticas internas de segurança da informação, ou não responderam aos convites por telefone ou e-mail do pesquisador.

\subsection{Trabalhos futuros}

Os resultados obtidos nesta pesquisa podem ser utilizados como base para trabalhos futuros. Realizar esta pesquisa anualmente pode mostrar a evolução do mercado com base na utilização de práticas prescritas para equilibrar risco e desempenho. É possível ampliar seu escopo para mais organizações, inclusive aquelas não certificadas ISO 20.000, para buscar um panorama mais completo das prestadoras de serviços de TI no país.

A estruturação das perguntas e respostas possíveis proposta na construção do instrumento de pesquisa da fase 2 pode ser usada para formar perguntas que possam ser adicionadas ao questionário da fase 1, consolidadas pelos fatores encontrados da relação risco versus desempenho. Assim se obtém um questionário mais completo para realizar uma pesquisa mais 
ampla, seja em organizações brasileiras, ou estrangeiras, certificadas ou não ISO 20.000, tendo como contexto comum a prestação de serviços de TI. Esta pesquisa pode ser estruturada com base em métodos quantitativos, utilizando técnicas de análise multivariada. Para tanto, as questões devem ser preparadas desde o início para coleta de dados desta adequados à aplicação das técnicas.

A visibilidade sobre os resultados e desempenho dos serviços de TI através de métricas é uma das características mais marcantes encontradas nos casos estudados. Um possível estudo futuro é ampliar o número de entrevistas dentro da mesma organização para buscar diferenças nos pontos de vista dos gestores e dos profissionais, tentando identificar quais pressões efetivamente são produzidas sobre os últimos ao terem que cumprir os processos prescritos, complementando o modelo apresentado na Seção 2.4.

Sobre o modelo canônico poderiam ser propostas revisões para levar em conta a utilidade relativa dos processos para as organizações, ajudando na definição de como aplicar o modelo a diferentes realidades, melhorando-o como caminho natural do amadurecimento das práticas do mercado de serviços de TI. 


\section{REFERÊNCIAS BIBLIOGRÁFICAS}

ABIB, Gustavo; HOPPEN, Norberto; RIGONI, Eduardo Henrique. A dimensão social no alinhamento estratégico entre negócio e TI. Revista Eletrônica de Sistemas de Informação, v.11, n.1, art.1, jan-jun/2012.

ABU-MUSA, Ahmad A. Exploring information technology governance (ITG) in developing countries: an empirical study. The International journal of digital accounting research, v.7, 2007.

ABU-MUSA, Ahmad A. Exploring the importance and implementation of COBIT processes in Saudi organizations: An empirical study. Information Management \& Computer Security, Emerald, v.17, n.2, p. 73-95, 2009.

ALEMANHA. Ministério Federal da Justiça e pela defesa do consumidor. Federal Data Protection Act. Saarbrücken, 2009.

ALI, Syaiful. Effective information technology governance mechanisms: an Australian study. Gadjah Mada International Journal of Business, v.8, n.1, p. 69-102, 2006.

ASSOCIAÇÃO BRASILEIRA DE NORMAS TÉCNICAS. ABNT. ABNT NBR ISO/IEC 20000-1: Tecnologia da informação - Gerenciamento de serviços - Parte 1: Requisitos do sistema de gerenciamento de serviços. São Paulo: ABNT, 2011. 
ASSOCIAÇÃO BRASILEIRA DE NORMAS TÉCNICAS. ABNT. ABNT NBR ISO/IEC 38500:2009: Governança de TI. São Paulo: ABNT, 2009.

ASSOCIAÇÃO BRASILEIRA DE NORMAS TÉCNICAS. ABNT. ABNT NBR ISO/IEC 19001:2002: Diretrizes para auditorias de sistema de gestão da qualidade e/ou ambiental. São Paulo: ABNT, 2002.

ABRAHAM, Sherly Elizabeth. Information technology, na enabler in corporate governance. Corporate governance, Emerald Group Publishing Limited, v.12, n.3, p.281-291, 2012.

ABRAHAMSON, Eric. Management fashion. Academy of Management Review, v.21, p. 254-285, 1996.

ALBERTIN, Rosa Maria de Moura; ALBERTIN, Alberto Luiz. Estratégia de governança de tecnologia da informação. Rio de Janeiro: Elsevier, 2010.

ALVES, Carlos André de Melo; CHEROBIM, Ana Paula Mussi Szabo. Contribuição para o estudo da gestão de riscos: evidenciação do risco operacional em quatro instituições financeiras brasileiras. Anais do $4^{\circ}$ Congresso USP de Controladoria e Contabilidade. São Paulo, 2004.

ALVES, Carlos Rodrigo Cordeiro. Fatores Comportamentais Relacionados à Governança de TI: Uma Visão Interna à Organização. 9o CONTECSI, São Paulo, p. 3917-3939, 2012. 
ALVES, Carlos Rodrigo Cordeiro; RIEKSTIN, Ana Carolina. Governança de TI - capítulo 2. In: PRADO, Edmir Parada Vasques; SOUZA, Cesar Alexandre de (Org.). Fundamentos de Sistemas de Informação. São Paulo: Elsevier, 2014.

ALVES, Carlos Rodrigo Cordeiro et al. IT governance frameworks: A literature review of Brazilian publications. In: INTERNATIONAL CONFERENCE ON INFORMATION RESOURCES, Anais Conf-IRM. Natal, 2013.

ANDRADE, Adriana; ROSSETI, José Paschoal. Governança Corporativa. São Paulo: Atlas, 2006.

APM GROUP. Disponível em: <http://www.isoiec20000certification.com/>. Acesso em: 18 dez. 2013.

AUBERT, Benoit A.; PATRY, Michel; RIVARD, Suzanne. A framework for information technology outsourcing risk management. The DATA BASE for Advances in Information Systems, v.36, n.4, 2005.

BAHLI, Bouchaib; RIVARD, Suzanne. Validating measures of information technology outsourcing risk factors. Omega - The International Journal of Management Science. Elsevier, n.33, p. 175-187, 2005.

BART, Chris; TUREL, Ofir. IT and the board of directors: an empirical investigation into the "governance questions" Canadian board members ask about it. Journal of Information Systems, v.24, n.2, p. 147-172, 2010. 
BAZERMAN, Max H.; MOORE, Don. Processo decisório. 7. ed. Rio de Janeiro: Campus, 2010.

BECK, Ulrich; BECK-GERNSHEIN, Elisabeth. Individualization. UK: Sage, 2002.

BELMONT, David P. Value added risk management in financial institutions: leveraging Basel II \& risk adjusted performance management. New York: John Wiley \& Sons, 2004.

BENAROCH, Michel et al. Option-based risk management: a field study of sequential information technology investment decisions. Journal of Management Information Systems, v.24, n.2, p. 103-140, 2007.

BÉNÉZÉCH, Danièle et al. Completion of knowledge codification: an illustration through the ISO 9000 standards implementation process. Research Policy, Elsevier, v.30, p. 1395-1407, 2001.

BHATT, Ganesh D.; GROVER, Varun. Types of information technology capabilities and their role in competitive advantage: an empirical study. Journal of Management Information Systems. M.E. Sharpe, v.22, n.2, p. 253-277, 2005.

BIDO, Diógenes de Souza. Implementação de sistemas da qualidade para a busca de certificação em pequenas e médias empresas do ramo automotivo. Dissertação (Mestrado em Administração) - Programa de Pós-Graduação em Administração da Faculdade de Economia, Administração e Contabilidade da Universidade de São Paulo. São Paulo, 1999 
BOYATZIS, Richard E. The competent management: a model for effective performance. New York: John Wiley, 1992.

BRANDÃO, Hugo Pena; GUIMARÃES, Tomás de Aquino. Gestão de competências e gestão de desempenho: tecnologias distintas ou instrumentos de um mesmo construto? Revista de Administração de Empresas (RAE), Fundação Getúlio Vargas, São Paulo, v. 41, n.1, p. 8-15, Jan/Mar, 2001.

BRASIL. Presidência da República. Lei no 12.965/2014 Marco Civil da Internet. Brasília, 2014.

BROWN, John Seely; DUGUID, Paul. Organizational learning and communities of practice: toward a unified view of working, learning and innovation. Organization Science, v.2, n.1, fev/1991.

BROWN, Allen E.; GRANT, Gerald G. Framing the frameworks: a review of IT governance research, Communications of the Association for Information Systems, v.15, p. 696-712, 2005.

BRYNJOLFSSON, Erik; HITT, Lorin M. Computing Productivity: Firm-Level Evidence. The Review of Economics and Statistics, v.85, n.4, p. 793-808, nov., 2003. 
BULCHAND-GIDUMAL, Jacques; MELIÁN-GONZÁLEZ, Santiago. Maximizing the positive influence of IT for improving organizational performance. Journal of strategic information systems. Elsevier, v.20, p. 461-478, 2011.

CALDWELL, Raymond. Agency and change. London: Routledge, 2006.

CARR, Nicholas G. IT doesn't matter. Harvard Business Review. Harvard Business School Publishing Corporation, p. 5-17, 2003.

CARVALHO, Marly Monteiro de; LAURINDO, Fernando José Barbin. Estratégia competitiva: dos conceitos à implementação. 2. ed. São Paulo: Atlas, 2006.

CARVAlHO, Tereza Cristina Melo de Brito. TI Tecnologia da Informação: Tempo de Inovação. São Paulo: MBooks, 2009.

CENTRAL BRASILEIRA DO SETOR DE SERVIÇOS - CEBRASSE. Disponível em: <http://www.cebrasse.org.br/1586>. Acesso em: 15/05/2014.

CERIONI, Thais; BUZO, Guilherme; SHIBATA, Luis Minoru. Brazil IT Snapshot. São Paulo: PromonLogicalis, 2014.

CLARKE, Thomas. Theories of Corporate Governance. New York: Routledge, 2004.

CLARKE, Thomas. International Corporate Governance: a comparative approach. New York: Routledge, 2007. 
CHAN, Yolande E.; REICH, Blaize Horner. IT alignment: what have we learned? Journal of Information Technology, Palgrave Macmillan Ltd., v.22, p. 297-315, 2007

CHATZOGLOU, Prodromos D.; DIAMANTIDIS, Anastasios D. IT/IS implementation risks and their impact on firm performance. International Journal of Information Management. Elsevier, v.29, p.119-28, 2009.

CHEN, Tao; ZHANG, Jinlong; LAI, Kin-Keung. An integrated real options evaluating model for information technology projects under multiple risks. International Journal of Project Management. Elsevier, v.27, p. 776-786, 2009.

CIBORRA, Claudio U. De profundis? Deconstructing the concept of strategic alignment. Scandinavian Journal of Information Systems, v.9, n.1, p.67-82, 1997.

CLEMENTI, Sérgio; CARVALHO, Tereza Cristina M.B. Methodology for IT Governance Assessment and Design. In: SUOMI, R. et al. (Org.). IFIP International Federation for Information Processing. Boston: Springer, v.226, p. 189-202, 2006.

CMMI INSTITUTE. Disponível em: <http://cmmiinstitute.com/results/who-uses-cmmi/>. Acesso em: 13/12/2013.

CMMI IN MEXICO. Disponível em: <https://everac99.wordpress.com/2012/07/23/cmmi-inmexico-and-around-the-world-2012/>. Acesso em: 13/12/2013. 
COLLAR, Emilio; LEE, Jintae. Information technology fashions: building on the theory of management fashions. Cambridge: MIT Sloan School of Management, 2002.

CORBETT, Charles J.; KIRSCH, David A. International diffusion of ISO 14000 certification. Production and Operations Management, Elsevier, v.10, n.3, p. 327-342, 2001.

COSTEA, Bogdan; INTRONA, Lucas D. Self and other in everyday existence. In: PULLEN, Alison; LINSTEAD, Stephen (Org.). Organization and identity. Routledge, New York, 2007.

COMMITTEE OF SPONSORING ORGANIZATIONS - COSO - Enterprise Risk Management: Integrated Framework. Treadway Commission, 2004.

COWAN, Robin; DAVID, Paul A.; FORAY, D. The explicit economics of knowledge codification and tactiness. Industrial and Coporate Change, v.9, n.2, p. 211-253, 2000.

PRADO, Edmir Parada Vasques; CRISTOFOLI, Fulvio. Resultados Obtidos com a Terceirização da Tecnologia da Informação em Empresas Brasileiras. AMCIS 2012 Proceedings. Lima: paper 4, 2012.

CUMPS, Bjorn; VIANE, Stijn; DEDENE, Guido. Linking the strategic importance of ICT with investment in business-ICT alignment: na explorative framework. International Journal on IT/Business Alignment and Governance, IGI Global, v.1, n.1, p. 39-57, jan-mar, 2010. 
CURKOVIC, Sime; PAGELL, Mark. A critical examination of the ability of ISO 9000 certification to lead a competitite advantage. Journal of Quality Management, v.4, n.1, p. 5167, 1999.

DE HAES, Steven; VAN GREMBERGEN, Wim. Analysing the impact of enterprise governance of IT practices on business performance. International Journal on IT/Business alignment and governance, v.1, n.1, p. 14-38, 2010.

DECOSTER, Sonia Rosa Arbues. Aspectos comportamentais no uso de sistemas ERP: um estudo em uma organização. Dissertação (Mestrado em Administração) - Programa de PósGraduação em Administração da Faculdade de Economia, Administração e Contabilidade da Universidade de São Paulo. São Paulo, 2008.

DESCARTES, René. Discurso do método. São Paulo: Escala, 2006.

DEUTSCHER, Jan-Helge; FELDEN, Carsten. Model concept to determine the optimal maturity of IT service management processes. ACIS International Conference on Computer and Information Science, IEEE, p. 543-548, 2009.

DIAS, Sheila Mara Oliveira. Fatores de pressão no trabalho e comprometimento com a carreira: um estudo com profissionais de tecnologia da informação (TI). Dissertação (Mestrado em Administração) - Programa de Pós-Graduação da Faculdade de Ciências Econômicas da Universidade FUMEC. Belo Horizonte, 2008. 
DISTERER, Georg. ISO 20000 for IT. Business \& Information Systems Engineering, v.6, p. 463-467, 2009.

DREHER, Felipe. Governo crava 50\% de imposto em serviços de DC prestados do exterior. Disponível em: <http://computerworld.com.br/negocios/2014/10/22/governo-crava-50-deimposto-em-servicos-de-dc-prestados-do-exterior/>. Acesso em: 01/dez/2014. Computerworld, 22 out. 2014.

DRUCKER, Peter F. La gerencia efectiva. 12. ed. Buenos Aires: Best Seller, 2007.

DUFFY, Jan. IT Governance and IT Operations. IDC, Lisbon, 2008.

DUTRA, Joel Souza. Competências: Conceitos e Instrumentos para a Gestão de Pessoas na Empresa Moderna. São Paulo: Atlas, 2004.

DUTRA, Joel Souza. O conceito de competência e sua contribuição para a gestão de carreira. In: CHAMON, Edna Maria Querido de Oliveira (Org.). Gestão de organizações públicas e privadas. Rio de Janeiro: Brasport, 2007.

DUTRA, Joel Souza; FLEURY, Maria Tereza Leme; RUAS, Roberto Lima (Org.). Competências: Conceitos, Métodos e Experiências. São Paulo: Atlas, 2008.

ELMES, Michael B.; STRONG, Diane M.; VOLKOFF, Olga. Panoptic empowerment and reflective conformity in enterprise systems-enabled organizations. Information and Organization, v.15, p. 1-37, 2005. 
EISENHARDT, Kathleen. M.; BOURGEOIS III, L. J. Politics of strategic decision making in high-velocity environments; toward a midrange theory. Academy of Management Journal, v. 31, n. 4, 1988.

LEITE FILHO, Geraldo Alemandro; Padrões de Produtividade de Autores em Periódicos de Congressos na Área de Contabilidade no Brasil: Um Estudo Bibliométrico. In: 6º Congresso USP de Controladoria e Contabilidade. Anais do Congresso USP de Controladoria e Contabilidade. São Paulo, 2006.

FERNANDES, Aguinaldo Aragon; DE ABREU, Vladimir Ferraz. Implantando a governança de TI. 2. ed. Rio de Janeiro: Brasport, 2008.

FISCHER, Rosa Maria. Mudança e transformação organizacional. In: FLEURY, Maria Tereza Leme (Org.). As pessoas na organização. São Paulo: Gente, p. 147-164, 2002.

FISCHER, Rosa Maria. O Círculo do Poder - As Práticas Invisíveis de Sujeição nas Organizações Complexas. In: FLEURY, Maria Tereza Leme; FISCHER, Rosa Maria. Cultura e Poder nas organizações. São Paulo: Atlas, p. 65-88, 1989.

FISHBEIN, Martin; AJZEN, Icek. Predicting and changing behavior: the reasoned action approach. New York: Psychology Press, Taylor \& Francis Group, 2010.

FLEURY, Afonso; FLEURY, Maria Tereza Leme. Estratégias empresariais e formação e competências. São Paulo: Atlas, 2000. 
FLEURY, Afonso; FLEURY, Maria Tereza Leme. Brazilian Multinationals. Cambridge: Cambridge University Press, 2012.

FONTÃO, Henio et al. Significance factors of IT leadership governance at the top 100 Brazilian companies. Proceedings: 7hㅡ CONTECSI, p. 455-471, 2010.

FORRESTER, Russ. Empowerment: rejuvenating a potent idea. The Academy of Management Executive, v.14, n.3, p.67, ago 2000.

GARTNER. Taming the Digital Dragon: The 2014 CIO Agenda. New York, 2014.

GARTNER. Top 10 CIO Business and Technology priorities in 2013. New York, 2013.

GHOBAKLOO, Morteza; ZULKIFLI, Norzima Binti; AZIZ, Faieza Abdul. The interactive model of user information technology acceptance and satisfaction in small and medium-sized enterprises. European Jornal of Economics, Finance and Administrative Sciences, EuroJournals Inc., n.19, 2010.

GITMAN, Lawrence J. Princípios de administração financeira. 10. ed. São Paulo: Pearson, 2003.

GODOY, Arlida Schmidt. Introdução à pesquisa qualitativa e suas possibilidades. Revista de Administração de Empresas, EAESP, FGV, v.35, n.2, p.57-63, mar/abr, 1995. 
GONÇALVES, A. P. et al. Proposal of evaluation model of alignment between business and IT strategies. Proceedings: 7hㅡ CONTECSI, p. 2768-2785, 2010.

GORDON, Judith R. Sistemas de informação: uma abordagem gerencial. 3. ed. Rio de Janeiro: LTC, 2006.

GUERRA, Sandra; FISCHMANN, Adalberto; MACHADO FILHO, Cláudio Antonio. An agenda for board research. Corporate ownership \& control, v.6, n.3, p. 196-202, 2009.

GUSTAFSSON, Roberth et al. Experiences from implementing ISO 9000 in small enterprises - a study of Swedish organization. The TQM Magazine, v.13, n.4, p. 232-246, 2001.

HAIR JR., Joseph F. et al. Análise multivariada de dados. 6. ed. São Paulo: Bookman, 2009.

HENDERSON, John C.; VENKATRAMAN, N. Strategic Alignment: Leveraging Information Technology For Transforming Organizations. IBM Systems Journal. v.32, n.1, p. 4-16, 1993.

HELP DESK INSTITUTE BRASIL - HDI. Pesquisa melhores práticas 2012/2013. São Paulo, 2013.

HERRIOTT, Robert E.; FIRESTONE, William A. Multisite qualitative policy research: optimizing description and generalizability. Educational Researcher, v.12, p.14-19, 1983.

HIND, Matthew. Are the cultures required to attain ISO 9000 and total quality management mutually exclusive? Training for Quality, v.4, n.2, p. 25-29, 1996. 
HIPÓLITO, José Antonio Monteiro; PLOTOW, Célia Bueno de André. Remuneração por competências: alternativas e implicações. In: DUTRA, Joel Souza et al. Competências: conceitos, métodos e experiências. São Paulo: Atlas, 2008.

HO, Joanna L.Y.; WU, Anne; XU, Sean Xin. Corporate governance and returns on information technology investment: evidence from an emerging market. Strategic Management Journal. New York: John Wiley \& Sons, n.32, p. 595-623, 2011.

HOCHSTEIN, Axel et al. Service-oriented IT management: benefit, cost and success factors. Proceedings 13: European Conference on Information Systems (ECIS), Regensburg, 2005.

HOFSTEDE, Geert. National and Organisational Culture. Disponível em: <http://geerthofstede.com/>. Acesso em: 20/06/2012.

HOFSTEDE, Geert. Cultura e organizações (1991). In: DUTRA, Joel Souza et al. (Org.). Competências: Conceitos, Métodos e Experiências. São Paulo: Atlas, 2008.

HSING, Chen Wen; SOUZA, Cesar Alexandre de. A metodologia de netnografia aplicada a sistemas de informação: investigação de comunidades virtuais de processos de negócios. XVI Semead, ISSN 2177-3866, p.1-15, out 2013.

HUANG, Dijiang et al. New Architecture for Intra-Domain Network. Communications of the ACM, v.49, n.11, novembro, 2006. 
HUGHES, Greg. Five steps to IT risk management best practices. Risk Management, v.53, n.7, 2006.

INSTITUTO BRASILEIRO DE GOVERNANÇA CORPORATIVA - IBGC. Código das Melhores Práticas de Governança Corporativa. 4. ed. São Paulo, 2009.

IDC. Latin America Vertical Market Spending Patterns 2012H2, set 2013.

INFORMATION TECHNOLOGY GOVERNANCE INSTITUTE - ITGI. Board Briefing on IT governance. Rolling Meadows, 2006.

INFORMATION TECHNOLOGY GOVERNANCE INSTITUTE - ITGI. Cobit mapping: mapping of ITIL with Cobit 4.0. Rolling Meadows, 2007.

INFORMATION TECHNOLOGY SERVICE MANAGEMENT FORUM INTERNATIONAL - ITSMF. Disponível em: <http://www.itsmfi.org/>. Acesso em: 15 mai. 2010.

INFORMATION SYSTEMS AUDIT AND CONTROL ASSOCIATION - ISACA. Cobit 5.0. Rolling Meadows, 2012.

INFORMATION SYSTEMS AUDIT AND CONTROL ASSOCIATION - ISACA. Enterprise risk: identify, govern and manage IT risk. Rolling Meadows, 2009.

JAMESON, Fredric. Representing Capital: a reading of volume one. London: Verson, 2011. 
JOHNSTON, Erik. Governance infrastructures in 2020. Public Administration Review, $\operatorname{dez} / 2010$.

KESSLER, Eric H.; CHAKRABARTI, Alok K. Innovation Speed: A Conceptual Model of Context, Antecedents, and Outcomes. Academy of Management, v.21, n.4, p. 1143-1191, 1996.

KITAGAWA, Carlos Henrique. Nível de adesão de empresas latino-americanas aos princípios de governança corporativa recomendados pela OECD. Dissertação (Mestrado em Controladoria e Contabilidade). Programa de Pós-Graduação em Contabilidade da Faculdade de Economia, Administração e Contabilidade de Ribeirão Preto da Universidade de São Paulo. Ribeirão Preto, 2007.

KO, Denise; FINK, Dieter. Information technology governance: an evaluation of the theorypractice gap. Corporate Governance, Emerald Group Publishing Ltd., v.10, n.5, p. 662-674, 2010.

KOBELSKY, Kevin; HUNTER, Starling; RICHARDSON, V.J. Information technology, contextual factors and the volatility of firm performance. International Journal of Accounting Information Systems, Elsevier, v.9, p. 154-174, 2008.

KONRAD, Alex. Salesforce.com Will 'Open The Door' For Customer Success Startups Like Gainsight. Disponível em: <http://www.forbes.com/sites/alexkonrad/2014/02/19/salesforce- 
com-will-open-the-door-for-customer-success-startups-like-gainsight/> . 20/dez/2014. Forbes, 19/fev/2014.

KOTLER, Philip; CASLIONE, John A. Chaotics: the business of managing and marketing in the age of turbulence. New York, Amacom, 2009.

LAI, Fong-Woon; SAMAD, Fazilah A. Enterprise Risk Management Framework and The Empirical Determinants of Its Implementation. International Conference on Business and Economics Research. Kuala Lumpur: IACSIT Press, v.1, 2011.

LE BOTERF, Guy. Desenvolvendo a competência dos profissionais. Porto Alegre: Artmed e Bookman, 2003.

LEE, Kie Sun; PALMER, Elaine. An empirical examination of ISO 9000-registered companies in New Zealand. Total Quality Management, v.10, n.6, 1999.

LEGGE, Karen. Human resources management. UK: Macmillan Business, 2005.

LIMA, Marcos A.M.; RESENDE, Marcelo; HASENCLEVER, Lia. Quality certification and performance of Brazilian firms: an empirical study. International Journal of Production Economics. Elsevier, v.66, p. 143-147, 2000.

LIPSEY, Mark W. Meta-analysis in evaluation research: moving from description to explanation. In: CHEN, Huey-Tsyh; ROSSI, Peter. Using theory to improve program and policy evaluations, New York: Greenwood, p.229-241, 1992. 
LO, Chris K.Y. et al. The impact of contextual factors on the efficacy of ISO 9000 adoption. Journal of Operations Management, Elsevier, v.31, p. 229-235, 2013.

LOPES, Paulo Cesar Barbosa et al. Gestão da mudança organizacional. UEPG Humanit. Sci. Appl. Soc. Sci. Linguist. - p. 51-57, 2003.

LOVE, Peter E.D. et al. The enigma of evaluation: benefits, costs and risks of IT in Australian small-medium-sized enterprises. Information \& Management, v.42, n.7, p. 947-964, 2005.

LUCIANO, Edimara Mezzomo; BECKER, Carlos Alberto; TESTA, Mauricio Gregianin. Competências individuais relevantes para os Chief Information Officers na percepção de profissionais de tecnologia da informação. Revista Eletrônica de Sistemas de Informação, v.11, n.1, art.5, jan-jun, 2012.

LUFTMAN, Jerry. Assessing business: IT alignment maturity. Communications of the Association for Information Systems, Atlanta, v.4, p. 1-50, 2000.

LUFTMAN, Jerry; BEN-ZVI, Tal. Key Issues for IT Executives 2010: Judicious IT Investments Continue Post-Recession. MIS Quarterly Executive, v.9, n.4, p. 263-73, 2010.

LUNARDI, Guilherme Lerch. Um estudo empírico e analítico do impacto da governança de TI no desempenho organizacional. Tese (Doutorado em Administração) - Programa de Pós-Graduação em Administração da Universidade Federal do Rio Grande do Sul. Porto Alegre, 2008. 
MAISTER, David H.; GREEN, Charles H.; GALFORD, Robert M. The trusted advisor. New York: The Free Press, 2000.

MAIZLISH, Bryan; HANDLER, Robert. IT portfolio management: step by step. New Jersey: John Wiley \& Sons, 2005.

MARQUES, Érico Veras; MOTA, Ariane Firmeza. Governança da tecnologia da informação: um estudo bibliométrico em eventos e periódicos brasileiros. Revista Eletrônica de Sistemas de Informação, v. 12, n. 2, 2013.

MAXIMIANO, Antonio Cesar Amaru. Teoria geral da administração. 6. ed. São Paulo: Atlas, 2008.

MCCLELLAND, David C. Testing for competence rather than for intelligence. American Psychologist. Washington, n.28, p. 1-4, 1973.

MCGUIRE, Stephen J.; DILTS, David M. The financial impact of standard stringency: an event study of successive generations of the ISO 9000 standard. International Journal of Production Economics, v.113, n.1, p. 3-22, 2008.

MEIRELlES, Fernando de Souza. Pesquisa Anual CIA, FGV-EAESP. 23. ed. São Paulo: FGV, 2012. 
MELVILLE, Nigel; KRAEMER, Kenneth; GURBAXANI, Vijay. Review: Information technology and organizational performance: an integrative model of IT business value. MIS Quarterly, v.28, n.2, p. 283-322, 2004.

MOHAMED, Norshidah et al. A conceptual framework for information technology governance effectiveness in private organizations. Information Management \& Computer Security, Emerald Group Publishing Ltd., v.20, n.2, p.88-106, 2012.

MOHRMAN JR., Allan M. et al. Large-Scale Organizational Change. San Francisco: JosseyBass Publishers, 1991.

MORAES, Altino José Mentzingen de. Cenário sobre governança de tecnologia da informação em grandes organizações no Brasil. Dissertação (Mestrado em Gestão do Conhecimento e da Tecnologia da Informação) - Programa de Pós-Graduação da Universidade Católica de Brasília. Brasília, 2007.

NAIR, Anand. Meta-analysis of the relationship between quality management practices and firm performance - implications for quality management theory development. Journal of Operations Management, Elsevier, v.24, p. 948-975, 2006.

NAVEH, Eitan; MARCUS, Alfred. Achieving competitite advantage through implementing and using ISO 9000. Journal of Operations Management, Elsevier, v.24, n.1, p.1-26, 2005. 
NEIROTTI, Paolo; PAOLUCCI, Emilio. Assessing the strategic value of information technology: an analysis on the insurance sector. Information \& Management, Elsevier, v.44, p. 568-582, 2007.

NFUKA, Edephonce N.; RUSU, Lazar. The effect of critical success factors on IT governance performance. Industrial Management \& Data Systems, Emerald Group Publishing Ltd., v.111, n.9, p. 1418-1448, 2011.

NIKOLIC, Bozo; RUZIC-DIMITRIJEVIC, Ljiljana. Risk Assessment of Information Technology Systems. Issues in Informing Science and Information Technology, v.6, p. 595$615,2009$.

OREIRO, José Luís; PUNZO, Lionello F.; ARAÚJO, Eliane C. Macroeconomic constraints to growth of the Brazilian economy: diagnosis and some policy proposals, Cambridge Journal of Economics, v.36, n.4, p. 919-39, 2012.

PINOCHET, Luis Hernan Contreras et al. Alinhamento estratégico do negócio com a adoção de mecanismos de governança de TI: o caso da Empresa Brasileira de Correios e Telégrafos. 9o CONTECSI, São Paulo, 2012.

PIRSON, Michael; TURNBULL, Shann. Toward a more humanistic governance model: network governance structures. Journal of Business Ethics, Springer, n.99, p. 101-114, 2011.

PIZZINATTO, Andrea Kassouf et al. Internal IT projects management: a study in top 100 Brazil's companies. Proceedings: 7는 CONTECSI - p. 2735-2749, 2010. 
PMI BRASIL. Disponível em: <https://brasil.pmi.org/brazil/>. Acesso em: 19 nov. 2014.

POWELL, Thomas C.; DENT-MICALLEF, Anne. Information technology as competitive advantage: the role of human, business, and technology resources. Strategic Management Journal, v.18, n.5, p. 375-405, 1997.

PRADO, Edmir Parada Vasques et al. Sourcing de serviços de TI em organizações privadas. REGE Revista de Gestão, v. 19, n. 1, São Paulo, 2012.

PRADO, Edmir Parada Vasques; SOUZA, Cesar Alexandre de (Org.). Fundamentos de sistemas de informação. São Paulo: Campus, 2014.

PRADO, Edmir Parada Vasques; TAKAOKA, Hiroo. A terceirização da tecnologia de informação e o perfil das organizações. Revista de Administração USP, São Paulo, v.41, n.3, 2006.

PRAHALAD, C. K.; HAMEL, Gary. The core competence of the corporation. Boston: Harvard Business Review, maio-junho, 1990.

PRASAD, Acklesh; HEALES, Jon; GREEN, Peter. A capabilities-based approach to obtaining a deeper understanding of information technology governance effectiveness: evidence from IT steering committees. International Journal of Accounting Information Systems, Elsevier, v.11, p. 214-232, 2010. 
QUINT. ITIL Survey. Miami: Quint Wellington Redwood, 2009.

RIDOLFO NETO, Arthur. Contabilidade e análise financeira: material de treinamento. FGV. São Paulo, 2009.

RIGONI, Eduardo Henrique; DWIVEDI, Rajeev; HOPPEN, Norberto. IT governance and business: IT strategic alignment commitment: a study of Brazilian firms. International Journal of Global Management Studies Professional. Association of Global Management Studies, v.2, n.1, p. 1-20, 2010.

RHINOW, Guilherme. O desafio de gestão da mudança em combinações empresariais: a indústria de ciências da vida. Tese (Doutorado em Administração) - Programa de PósGraduação em Administração da Faculdade de Economia, Administração e Contabilidade da Universidade de São Paulo. São Paulo, 2006.

ROBBINS, Stephen P. Comportamento organizacional. 11. ed. New Jersey: Pearson-Prentice Hall, 2006.

ROMERO, Steven. An IT governance confusion solution. Internal auditor. The Institute of Internal Auditors, p. 67-69, fev/2012.

RUZEVICIUS, J.; ADOMAITIENE, R.; SIRVIDAITE, J.. Motivation and efficiency of quality management systems implementation: a study of Lithuanin organizations. Total Quality Management. Routledge, v.15, n.2, p. 173-189, 2004. 
SALLES, G. B. M.; ALBUQUERQUE, J. P. Strategic management of information technology:

a case study in a large-scale Brazilian financial organization originated from a merge. Proceedings 7 $\underline{\text { th }}$ CONTECSI - p. 2850-2873 - 2010.

SAMBAMURTHY, V.; ZMUD, Robert W. Arrangements for Information Technology Governance: A Theory of Multiple Contingencies. MIS Quarterly, v.23, n.2, p. 261-290, 1999.

SAMSON, Danny; TERZIOVSKI, Mile. The relationship between total quality management practices and operational performance. Journal of Operations Management. Elsevier, v.17, p.393-409, 1999.

SASAKI, Luís Hiromitsu. Gestão da qualidade para empresas prestadores de serviços de instalação do sistema de telecomunicações. Dissertação (Mestrado Profissional em Engenharia Mecânica) - Programa de Pós-Graduação da Faculdade de Engenharia Mecânica da Unicamp. Campinas, 2001.

SELLTIZ, Claire et al. Métodos de pesquisas das relações sociais. São Paulo: Herder, 1965.

SEYLE, D. Connor; SWANN JR., William B. Being oneself in the workplace: self-verification and identity in organizational contexts. In: BARTEL, Caroline A. et al. Identity and the modern organization. New Jersey, p.201-22, 2007.

SENGE, Peter. The fifth discipline: the art and practice of the learning organization. New York: Currency Doubleday, 2006. 
SILVEIRA, Alexandre di Miceli. Governança corporativa no Brasil e no mundo. São Paulo: Campus, 2010.

SILVEIRA, Alexandre di Miceli; BARROS, Lucas Ayres B. de C. Corporate governance quality and firm value in Brazil. Campinas: Unicamp, 2007.

SIMONSSON, Mårten; JOHNSON, Pontus. Defining IT Governance: a consolidation of literature. EARP Working Paper. Suécia, 2005. Disponível em: $<$ http://citeseerx.ist.psu.edu/viewdoc/summary?doi=10.1.1.64.6388>. Acesso em: 30 jun. 2010.

SINGH, Prakash J. Empirical assessment of ISO 9000 related management practices and performance relationships. International Journal of Production Economics. Elsevier, v.113, p.40-59, 2008.

SIQUEIRA, Erica Souza; SOUZA, Cesar Alexandre de; VIANA, Adriana Backx Noronha. Uso da tecnologia de informação em empresas de pequeno e médio porte: uma análise a partir dos dados da pesquisa TIC Empresas de 2011. 90 CONTECSI, São Paulo, 2012.

SOH, Christina; MARKUS, M. Lynne. How IT creates business value: a process theory synthesis. 16 $^{\text {th }}$ International Conference on Information Systems. Amsterdam, 1995.

SOTTO, Richard. The virtualization of the organizational subject. In: CHIA, Robert C.H. (Org.). Organized Worlds: Explorations in Technology and Organization with Robert Cooper. London: Routledge, 1998. 
SOULA, Jose Maria Fiorino. ISO/ IEC 20000: Gerenciamento de Serviços de Tecnologia da Informação: Teoria e Prática. Rio de Janeiro: Brasport, 2013.

SOUTHEY, Gregory. The theories of reasoned action and planned behaviour applied to business decisions: a selective annotated bibliography. Journal of New Business Ideas \& Trends, v.9, n.1, p.43-50. 2011.

SOUZA, Cesar Alexandre de. Uso organizacional da tecnologia de informação: um estudo sobre a avaliação do grau de informatização de empresas industriais paulistas. Tese (Doutorado em Administração) - Programa de Pós-Graduação em Administração da Faculdade de Economia, Administração e Contabilidade da Universidade de São Paulo. São Paulo, 2004.

STANDARDS

ORGANIZATION.

Disponível

em:

<http://www.standards.org/standards/listing/iso_20000>. Acesso em: 13 mar. 2013.

STEVENSON, Thomas H.; BARNES, Frank C. What industrial marketers need to know now about ISO 9000 certification: a review, update, and integration with marketing. Industrial Marketing Management, North-Holland, v.31, p. 695-703, 2002.

STONEBURNER, Gary; GOGUEN, Alice; FERINGA, Alexis. Risk Management Guide for Information Technology Systems. Gaithersburg: NIST - National Institute of Standards and Technology, 2002. 
STRAUSS, Anselm; CORBIN, Juliet. Basics of qualitative research. Londres: Sage Publications, 1990.

SURVEYMONKEY (ferramenta para pesquisas). Disponível em: <http://www.surveymonkey.com>. Acesso em: 19 jan. 2014.

TALLON, Paul P.; PINSONNEAULT, Alain. Competing perspectives on the link between strategic information technology alignment and organizational agility: insights from a mediation model. MIS Quarterly, v.35, n.2, p. 463-486, junho, 2011.

TAROUCO, Hiury Hakim; GRAEMI, Alexandre Reis. Governança de tecnologia da informação: um panorama da adoção de modelos de melhores práticas por empresas brasileiras usuárias. Revista de Administração, v.46, n.1, p. 7-18, jan/fev/mar, 2011.

TAYLOR, W. Andrew. Senior executives and ISO 9000: attitudes, behaviours and commitment. International Journal of Quality \& Reliability Management, v.12, n.4, pp. 40$57,1995$.

TAYLOR, Sharon. et al. Service Design (ITIL v3). Edimburgo: The Stationery Office, 2007.

TERZIOVSKI, Milé; POWER, Damien; SOHAL, Amrik S. The longitudinal effects of the ISO 9000 certification process on business performance. European Journal of Operations Research, v.146, p.580-95, 2003. 
THE ECONOMIST. Brazil takes off. Disponível em: <http://www.economist.com/node/14845197>. Acesso em: 13 nov. 2012. New York, ed. 14 nov. 2009.

THIBODEAU, Patrick. GM to hire 10,000 IT pros as it 'insources' work. Disponível em: <http://www.computerworld.com/article/2492198/it-careers/gm-to-hire-10-000-it-pros-as-it-insources--work.html>. Acesso em: 15 jan. 2014. Computerworld, 07 set. 2012.

TI INSIDE ONLINE. Europa divulga plano para regulamentar serviços de computação em nuvem. Disponível em: <http://convergecom.com.br/tiinside/27/09/2012/europa-divulgaplano-para-regulamentar-servicos-de-computacao-em-nuvem/\#.VJbYdF4APA>. Acesso em: 01 dez. 2014.

TIROLE, Jean. The Theory of Corporate. New Jersey: Princeton University Press, 2006.

TOFFLER, Alan. Future shock. New York: Random House, 1970.

TURBAN, Efraim; RAINER JR., R. Kelly; POTTER, Richard E. Administração de tecnologia da informação: teoria e prática. 7. tiragem. São Paulo: Campus, 2005.

VAN GREMBERGEN, Wim; DE HAES, Steven. Implementing information technology governance. Hershey: IGP Global, 2008. 
VAN GREMBERGEN, Wim; DE HAES, Steven; GULDENTOPS, Erik. Structures, processes and relational mechanisms for IT governance. In: VAN GREMBERGEN, W. (Org.). Strategies for information technology governance. Hershey: Idea Group Publishing, 2004.

VANTI, Nadia Aurora Peres. Da bibliometria à webometria: uma exploração conceitual dos mecanismos utilizados para medir o registro da informação e a difusão do conhecimento. Ciência da Informação, v.31, n.2, p. 152-162, 2002.

WALES. Business. Cloud Computing. Disponível em: <http://business.wales.gov.uk/cloudcomputing>. Acesso em: 20/dez/2014.

WALSHAM, Geoff. Interpretative research methodology. XXVII ENANPAD, palestra, São Paulo, set 2003 apud SACCOL, Amarolinda. I.C. Zanela. A teoria da hospitalidade e o processo de adoção de tecnologias da informação móveis e sem fio. Tese (Doutorado em Administração) - Programa de Pós-Graduação em Administração da Faculdade de Economia, Administração e Contabilidade da Universidade de São Paulo. São Paulo, 2005.

WEBSTER, Jane; WATSON, Richard T. Analyzing the Past to Prepare for the Future: Writing a Literature Review. MIS Quarterly Executive, v.26, n.2, p. xiii-xxiii, 2002.

WEILL, Peter; ROSS, Jeanne W. IT governance. Boston: Harvard Business School Press, 2004.

WEILL, Peter; WOERNER, Stephanie L. The future of the CIO in the digital economy. MIS Quarterly Executive, v.12, n.2, p. 65-75, 2013. 
WILKIN, Carla L.; CHENHALL, Robert H. A review of IT Governance: a taxonomy to inform accounting information systems. Journal of Information Systems, American Accounting Association, v.24, n.2, p. 107-146, 2010.

XUE, Yajiong; LIANG, Huigang; BOULTON, W.R. Information technology governance in information technology investment decision processes: the impact of investment characteristics, external environment, and internal context. MIS Quarterly, v.32, n.1, p. 67-96, 2008.

YAO, Lee J.; LIU, Chunhui; CHAN, Siew H. The influence of firm specific context on realizing information technology business value in manufacturing industry. International Journal of Accounting Information Systems, Elsevier, v.11, p. 353-362, 2010.

YEH, Quey-Jen; CHANG, Arthur Jung-Ting. Threats and countermeasures for information system security: A cross-industry study. Information \& Management. Elsevier, v.44, n.5, p. 480-491, 2007.

YIN, Robert K. Case study research: design and methods. 4th. ed. Thousand Oaks: Sage, 2009.

ZWICKER, Ronaldo et al. Grau de informatização de empresas. RAE-eletrônica v.6, n.2, São Paulo, 2007. 


\section{GLOSSÁRIO}

BPO - Business Process Outsourcing

BSC - Balanced Score Card

CLT - Consolidação das Leis Trabalhistas

CMM - Capability Maturity Model

CMMI - Capability Maturity Model Integrated

Cobit - Control Objectives for Information and related Technology

G. - Gerenciamento

HW - Hardware

ISO - International Organization for Standardization

ITGI - Information Technology Governance Institute

ITIL - Information Technology Infrastructure Library

ITO - Infrastructure Technology Outsourcing

ISACA - Information Systems Audit and Control Association

PCI-DSS - Payment Card Industry Data Security Standard

PMBoK - Project Management Body of Knowledge

RFP - Request For Proposal

SW - Software

TRA - Theories of Reasoned Action: Teorias da Ação Racional

USB - Universal Serial Bus

VPN - Virtual Private Network 


\section{APÊNDICES}

APÊNDICE 1 - MODELO DA CARTA CONVITE

APÊNDICE 2 - QUESTIONÁRIO UTILIZADO NA PRIMEIRA FASE DE COLETA APÊNDICE 3 - ANÁLISE MULTIVARIADA DE DADOS

APÊNDICE 4 - MODELO CANÔNICO: REQUISITOS DA NORMA ISO 20.000 


\section{APÊNDICE 1 - MODELO DA CARTA CONVITE}

\section{A $<<$ entrevistado $>>$, <<Organização>>}

São Paulo, 15 de julho de 2014

Esta é uma pesquisa conduzida por Carlos Alves, doutorando em Administração de Empresas pela FEA-USP, orientado pelo Prof. Dr. Antonio G. R. Vidal. Trata-se de um levantamento de dados sobre empresas brasileiras certificadas ISO 20.000.

As práticas relacionadas à governança de Tecnologia da Informação (em especial CobiT e ITIL) receberam grande atenção nos últimos anos em empresas de tecnologia da informação no Brasil. Esta adoção gerou uma série de diferentes usos e aplicações dos conceitos. A principal motivação para esta pesquisa é entender os benefícios dos investimentos relacionados à certificação, observando como se deu o processo de implantação da norma.

Os principais objetivos desta pesquisa são:

- Aprofundar o conhecimento sobre a adoção de práticas de governança de TI;

- Desenvolver o modelo de fatores que influenciam a implantação dos modelos de governança de TI;

- Verificar como a adoção de modelos de governança de TI se dão nas organizações, podese questionar a validade e quantidade de investimentos realizados por gestores na adoção de modelos de referência as is: treinamentos, consultorias, ferramentas entre outros

Como contrapartida, sua organização receberá os resultados desta pesquisa, obtendo uma visão sobre seu próprio processo de adoção da norma e uma comparação com relação a outras organizações brasileiras que adotaram as mesmas práticas.

Este questionário é a primeira parte do levantamento de dados cujo objetivo é verificar quais processos da norma são considerados mais críticos para a obtenção de benefícios com a certificação da organização. 
A segunda etapa desta pesquisa será conduzida através de entrevistas com profissionais das empresas que responderam ao questionário. O objetivo é detalhar como os processos destacados como críticos foram implantados, principalmente com relação aos impactos à organização, aos negócios e aos profissionais.

Muito obrigado pela colaboração,

Carlos Rodrigo C. Alves

crcalves@usp.br - Número USP: 2377105

Informações de contato

Nome:

E-mail:

Organização:

Assinatura: 


\section{APÊNDICE 2 - QUESTIONÁRIO UTILIZADO NA PRIMEIRA FASE DE COLETA}

O questionário foi dividido em três páginas web (com scroll).

\section{Página 1:}

\section{Relação risco versus desempenho em governança de TI}

\section{FEAUSP}

Esta é uma pesquisa conduzida por Carlos Alves, doutorando em Administração de Empresas pela FEA-USP, orientado pelo Prof. Dr. Antonio G. R. Vidal. Trata-se de um levantamento de dados sobre empresas brasileiras certificadas ISO 20.000 .

Este questionário é a primeira parte do levantamento de dados cujo objetivo é verificar quais processos da norma são considerados mais críticos para a obtenção de benefícios com a certificação da organização.

\section{Nome} (opcional)

\section{*2. Cargo}

*3. Organização

*4. Qual o tamanho de sua organização?

(em número de profissionais)
até 100
100 a 1.000
1.001 a 2.500
maior que 2.500

*5. Como é o processo de decisão sobre investimentos em TI?

Gestores da empresa (C-level)

Área de TI

Gestores das áreas de negócio

Gestores da empresa (C-level) em conjunto com as áreas de negócio 
Disperso entre áreas usuárias

*6. Qual a ordem de grandeza de investimentos em certificações, treinamentos, consultorias e atividades internas e especificamente voltadas à certificação ISO $20.000 ?$

(em $\mathrm{R} \$$ ou \% do orçamento)

* 7. Quais outros modelos padronizados de governança de TI sua organização adota?

(marque quantas opções foram aplicáveis)

$\begin{array}{ccc}\text { Adotado } & \begin{array}{c}\text { Investimento em certificação } \\ \text { de profissionais }\end{array} & \text { Não utilizado }\end{array}$

Cobit

ITIL

PMBoK

BSC (Balanced

ScoreCard)

$\mathrm{CMM} / \mathrm{CMMI}$

Six Sigma (Seis

Sigma)

* 8. Com relação à estratégia de adoção da norma, pode-se afirmar que: (responda sobre a escala, tendo os critérios abaixo como extremos)

A organização já possuía os processos, que foram adaptados aos requisitos da norma.
Os processos foram criados a partir dos requisitos prescritos na norma. 
Página 2

Relação risco versus desempenho em governança de TI

* 9. Classifique os processos da norma ISO 20.000 que você considera como tendo maior impacto à sua organização.

(1: mais importante; 5: menos importante) - marque APENAS cinco

Desenho e transição

ordem

de serviços novos

ou modificados

Gerenciamento de

nível de serviço

Plano de

continuidade $\mathrm{e}$

disponibilidade de

serviço

Orçamento e

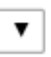

contabilização para

serviços

Gerenciamento da

capacidade

Gerenciamento da

segurança da

informação

Gerenciamento de

relações de negócio

Gerenciamento de

fornecedores

Gerenciamento de

incidentes e

requisições de

serviço

Gerenciamento de

problemas

Gerenciamento de

configuração

Gerenciamento de

mudanças

Gerenciamento de

liberações e

implantação

*10. Ordene as razões mais importantes pelas quais sua organização optou por 
se certificar ISO 20.000 .

(1: mais importante; 5 : menos importante) - marque APENAS cinco

Exigência de

clientes

Exigência de

fornecedores

Exigência da

ordem

governança

corporativa

Pressão dos

concorrentes (por

exemplo: eles já

haviam se

certificado)

Necessidade

relacionada a

oportunidades de

mercado

Estabelecer uma

linguagem comum

sobre os processos

dentro da

organização

Outro (especifique)

*11. Ordene os fatores mais importantes para o sucesso da sua organização adotando a norma ISO 20.000 .

(1: mais importante; 5: menos importante) - marque APENAS cinco

Obter
comprometimento
da alta
administração
Promover educação
/ mudança da
cultura dos
funcionários
Respeitar o
funcionário, com
relação à
comunicação clara
de seus objetivos
Definir métricas do


processo ou da

gestão

Estabelecer

políticas de

gerenciamento

Controlar planos e

ações de melhoria

Aumentar o foco no

cliente

Valorizar

profissionais

competentes

Buscar fornecedores

confiáveis

Ter um sistema de

comunicação eficaz

Estabelecer

processos eficazes

Planejar a

implantação de

processos

Obter ajuda externa

à organização (ex.:

consultorias,

professores)

Investir em

educação e

treinamento

Melhorar a qualidade

da documentação

Outro (especifique)

*12. Ordene os fatores mais relevantes para o desempenho de sua organização. (1: mais importante; 4 : menos importante)

Intensidade do ordem

aprendizado

organizacional

Experiência no

negócio-fim de TI

Estrutura de

relacionamento

Qualidade da

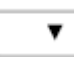


infraestrutura de TI

Outro (especifique)

*13. Ordene os pontos mais relevantes para se obter sucesso nos negócios de TI.

(1: mais importante; 5: menos importante) - marque APENAS cinco

\begin{tabular}{l} 
Política, planos e \\
ações de \\
gerenciamento \\
Foco nos clientes \\
Empregados \\
capazes \\
Fornecedores \\
confiáveis \\
Sistema de \\
comunicação eficaz \\
Processos eficazes \\
Entrega consistente \\
de qualidade \\
Clientes satisfeitos \\
Outro (especifique) \\
\hline
\end{tabular}

*14. Ordene as maiores dificuldades enfrentadas para manter o sistema de governança de TI funcionando.

(1: mais importante; 5 : menos importante) - marque APENAS cinco

ordem

Comprometimento

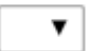

da alta

administração

Educação /

mudança da cultura

dos funcionários

Respeito pelo

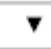

funcionário

Definição de

métricas do

processo ou da

gestão

Estabelecer 
políticas de

gerenciamento

Controlar planos e

ações de melhoria

Aumentar o foco no

cliente

Valorizar

profissionais

competentes

Buscar fornecedores

confiáveis

Ter um sistema de

comunicação eficaz

Estabelecer

processos eficazes

Planejar a

implantação de

processos

Obter ajuda externa

à organização (ex.:

consultorias,

professores)

Investir em

educação e

treinamento

Melhorar a qualidade

da documentação

Outro (especifique)

*15. Dentre estes fatores externos à organização, ordene os que têm maior impacto sobre o investimento de TI.

(1: mais importante; 5 : menos importante) - marque APENAS cinco

\author{
Ameaça de \\ concorrentes novos \\ Poder de barganha \\ dos fornecedores \\ Poder de barganha \\ dos clientes \\ Rivalidade entre \\ concorrentes
}

ordem

Ameaça de

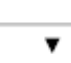


produtos/serviços

substitutos

Outro (especifique)

*16. Dentre estes fatores internos à organização, ordene os que têm maior impacto sobre o investimento de $\mathrm{Tl}$.

(1: mais importante; 5 : menos importante)

\begin{tabular}{l|r|} 
Ativos & \\
(equipamentos, \\
hardware, software) \\
Técnico \\
Gerencial \\
Operacional \\
Político \\
Outro (especifique) \\
\hline
\end{tabular}

*17. Qual é tipicamente a atitude da organização perante os riscos? (marque sua resposta de acordo com a escala abaixo)

Completamente

*18. Diante de uma oportunidade inovadora com um cliente, qual é tipicamente a atitude da organização?

Evita o risco

Reduz/mitiga os riscos

Compartilha/transfere os riscos

Aceita o risco

*19. Ordene os seguintes tipos de risco em sua organização, de acordo com sua importância relativa.

(1: mais importante; 5 : menos importante)

Técnico
Projeto
Operacional

ordem

Técnico

Operacional

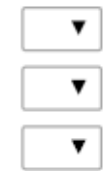


Política interna

Otimismo da

gerência

Outro (especifique)

*20. Ordene os seguintes riscos operacionais de TI, de acordo com a importância relativa dada a eles em sua organização.

(1: mais importante; 5: menos importante) - marque APENAS cinco

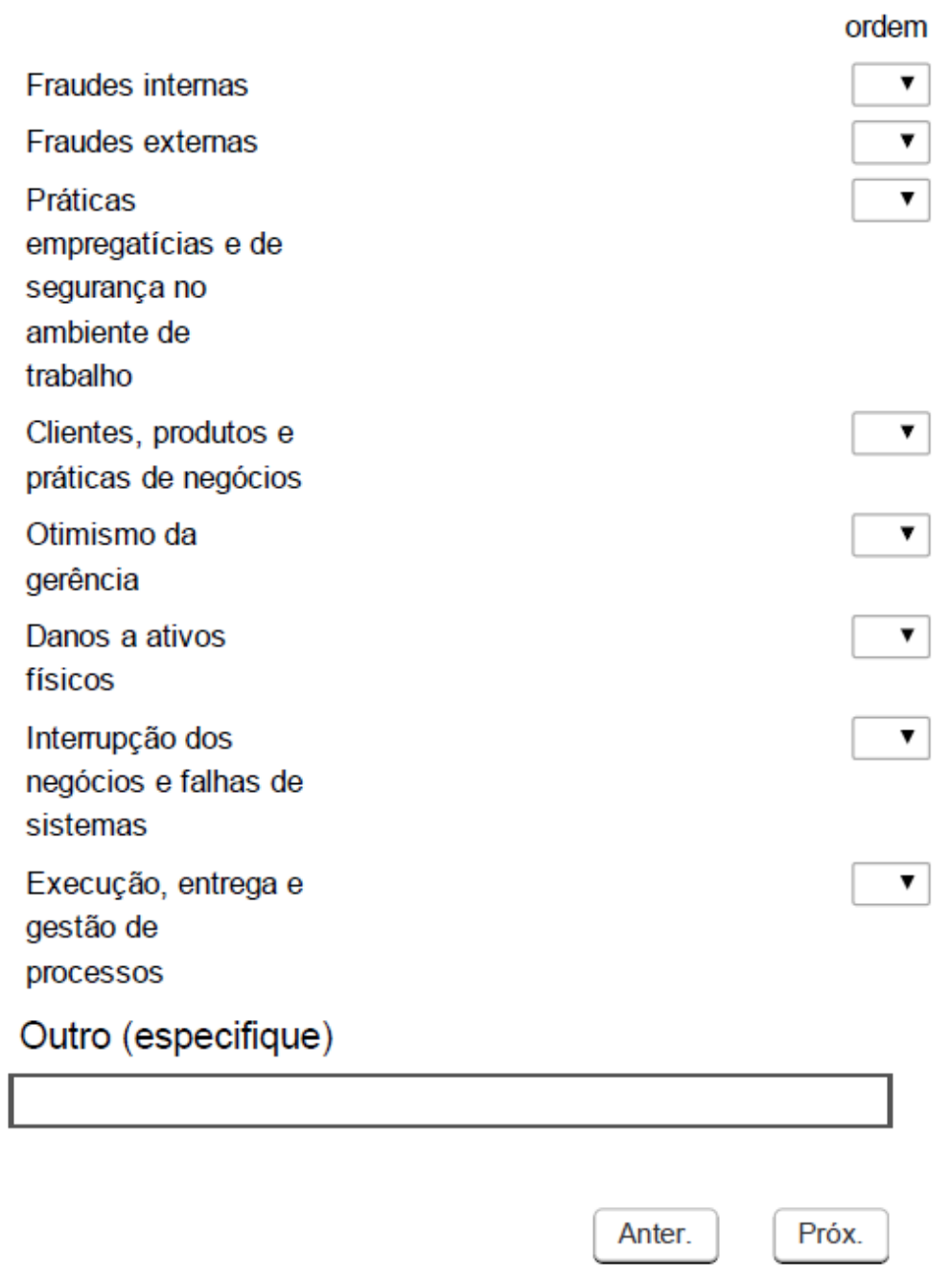


Página 3

Relação risco versus desempenho em governança de TI

*21. Os processos de gerenciamento de TI foram comunicados?

Discordo totalmente

Concordo totalmente

*22. As atividades são registradas formalmente (em papel, ferramentas, sistemas, planilhas, etc.)?

Não

Sim, mas não sei dizer como

Sim, e sei dizer como

Sim, e tenho responsabilidade sobre os registros

Sim, tenho esta responsabilidade e acompanho os resultados através de indicadores

\section{*23. Como o chefe imediato acompanha os resultados?}

Não cobra

Somente se os resultados foram ruins

Comunica os resultados, sejam bons ou ruins

Acompanha e propõe planos de melhoria

Os planos de melhoria influenciam outros processos e podem ser compartilhados com clientes

\section{*24. Classifique as ações e atitudes da chefia quanto a decisões de negócio.}

Dá muita autonomia

Solicita opiniões, inclusive de outras áreas e toma a decisão em conjunto

Solicita opiniões e decide em grupo, envolvendo os funcionários

Solicita opiniões, mas decide sozinho

É autoritário e decide sozinho

\section{*25. Classifique as ações/atitudes da chefia quanto a atividades do dia-a-dia.}

Dá muita autonomia

Solicita opiniões, inclusive de outras áreas e toma a decisão em conjunto

Solicita opiniões e decide em grupo, envolvendo os funcionários

Solicita opiniões, mas decide sozinho

É autoritário e decide sozinho 
* 26. Você conhece os processos de governança de TI que afetam sua área?

* 27. Você ajudou na definição e nas revisões dos processos de governança de TI?

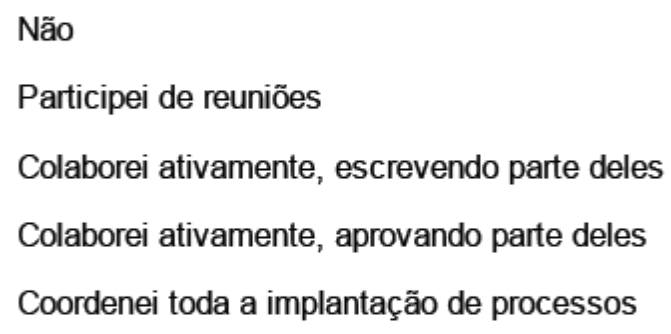

* 28. Os processos de governança de TI refletem a realidade das atividades realizadas no

dia-a-dia?

Discordo totalmente

Concordo totalmente

* 29. Você propôs mudanças nos processos de governança de TI? Discordo totalmente

Concordo totalmente

* 30. Você segue os processos de governança de TI conforme estão documentados?

Discordo totalmente

Concordo totalmente

* 31. Houve apoio e incentivo da alta direção na adoção dos processos de governança de TI?

Discordo totalmente

Concordo totalmente

32. Comentários adicionais. 


\section{APÊNDICE 3 - ANÁLISE MULTIVARIADA DE DADOS}

Fez-se um estudo complementar com técnicas de análise multivariada sobre os dados coletados. Buscou-se identificar conclusões comuns às análises qualitativas feitas ao longo dos questionários e entrevistas. Para estudos futuros, é possível modificar os instrumentos de pesquisa para aumentar o número de organizações que respondam ao questionário para que se possa fazer um estudo mais amplo sobre governança de TI no Brasil.

Os processos foram apontados como principal fator de diferenciação e críticos para o sucesso do gerenciamento dos serviços de TI, conforme apresentado na

Tabela 18. Isto mostra uma preocupação dos gestores em implantar controles para uniformizar as práticas na operação diminuindo a probabilidade de erros.

Observando as respostas obtidas, foi possível agrupar as organizações de acordo com características solicitadas nos questionários. A Figura 44 apresenta a distribuição em duas dimensões das organizações, representadas por seu número preposto de "VAR", de acordo com as respostas do questionário da fase 1 que podiam ser traduzias em escalas, referentes a tamanho da organização (Q4), estrutura de decisão (Q5), estratégia de adoção da norma (Q8), atitude perante o risco (Q17 e Q18) e características dos profissionais (Q21 a Q31). Aplicou-se a técnica de análise multivariada escalonamento multidimensional (HAIR JR. et al., 2009), através da ferramenta IBM SPSS v22, com modelo ordinal, intervalo de distância euclidiana quadrática, valores transformados por Z-scores por variável e com matriz de distância entre casos. Porém a análise apresentou stress $=11,9 \%$ e $\mathrm{RSQ}=0,92$, considerado apenas razoável. Através de tentativas, foi retirada da análise a variável de estrutura de decisão (Q5). Com isto obteve-se stress $=5,0 \%$ e $\mathrm{RSQ}=0,99$, níveis considerados bons no uso deste modelo. $\mathrm{O}$ significado das duas dimensões foi determinado pelo pesquisador de acordo com os dados coletados nesta pesquisa. 


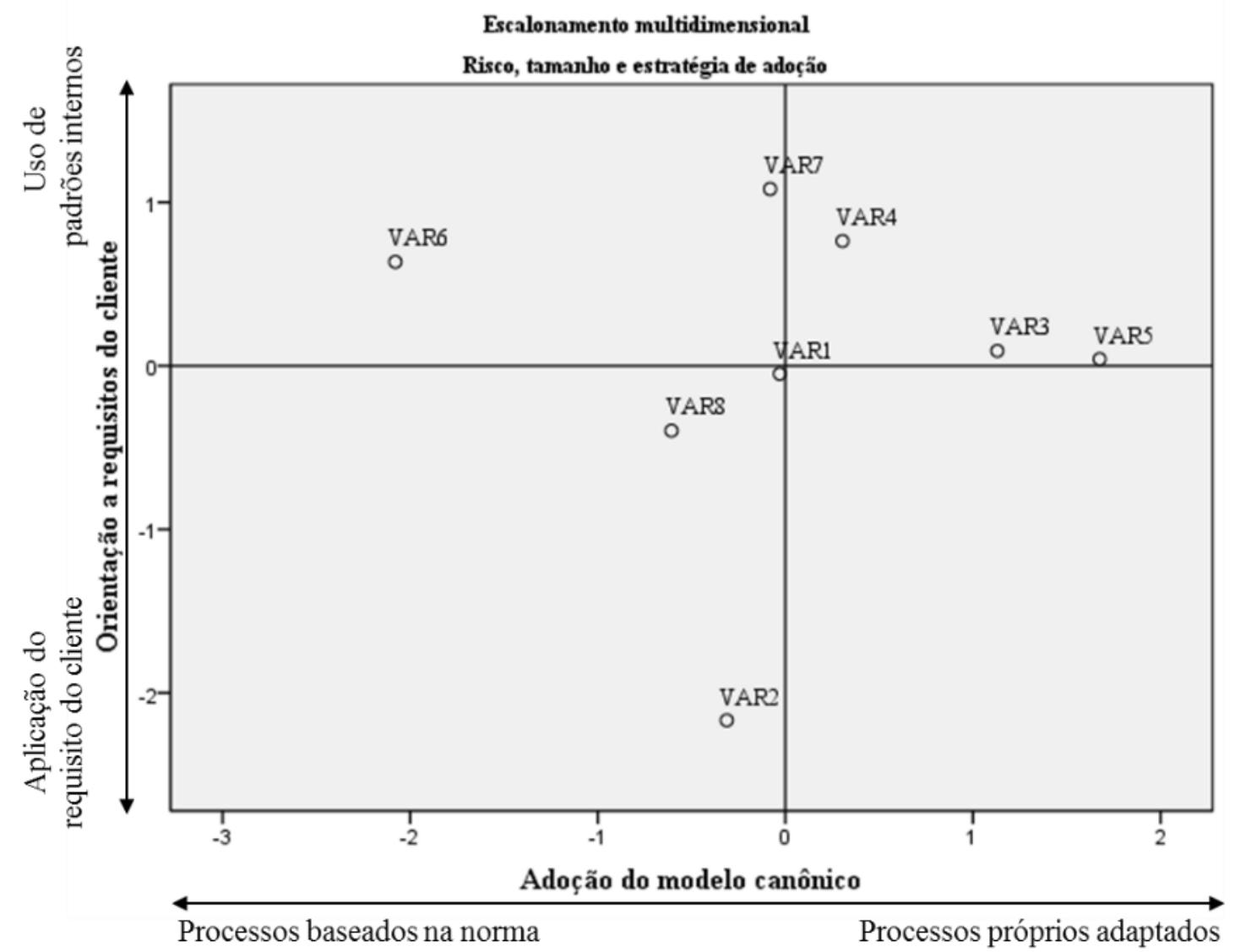

Figura 44 - Distribuição das organizações de acordo com as respostas do questionário da fase 1.

Em oposição estão os casos 5 e 6, sendo que o segundo apoiou sua definição dos processos de governança de TI no modelo canônico. O caso 7 difere de 2 pois busca primeiramente apresentar ao cliente um modelo padrão de seus serviços, ao invés de atender especificamente o que o cliente busca forçando alterações de processos internos.

Foi aplicada análise de conglomerados para considerar o agrupamento das organizações de acordo com sua atitude perante riscos (Q17 e Q18). Utilizou-se a ferramenta IBM SPSS v22, com distância euclidiana quadrática, obtendo-se o seguinte resultado:

- $\quad$ Conglomerado 1 - avesso a risco: 1, 4, 6, 7, 8 .

- $\quad$ Conglomerado 2 - disposto a arriscar: 2, 3, 5.

Neste exercício verificou-se que a introdução da variável sobre o tamanho das organizações (Q4) não interferiu no resultado. 
A análise dos questionários leva em conta os fatores: visibilidade das ações, controle, reflexão em práticas e conformidade a regras, apresentados na Figura 4. Com relação aos indivíduos, nota-se uma relação entre visibilidade das ações e reflexão em práticas e entre controle e conformidade a regras. Quanto mais marcante a visibilidade de ações, maior é a reflexão em práticas uma vez que os profissionais são gerenciados através de métricas estabelecidas pela liderança, ao invés de práticas coercitivas de controle. Por outro lado, quanto menos acentuado o controle, maior a reflexão em práticas: em um ambiente de melhoria contínua espera-se que os profissionais proponham evoluções das atividades da operação. Estes resultados apresentados na Figura 45 são coerentes com as conclusões obtidas em estudo anterior pelo autor (Alves, 2012).

Tomando apenas as variáveis sobre a atitude dos profissionais (Q21 a Q31), usou-se o escalonamento multidimensional, com modelo ordinal, intervalo de distância euclidiana quadrática, valores transformados por Z-scores por variável e com matriz de distância entre casos, obteve-se stress $=5,5 \%$ e $\mathrm{RSQ}=0,99$, níveis considerados bons no uso deste modelo.

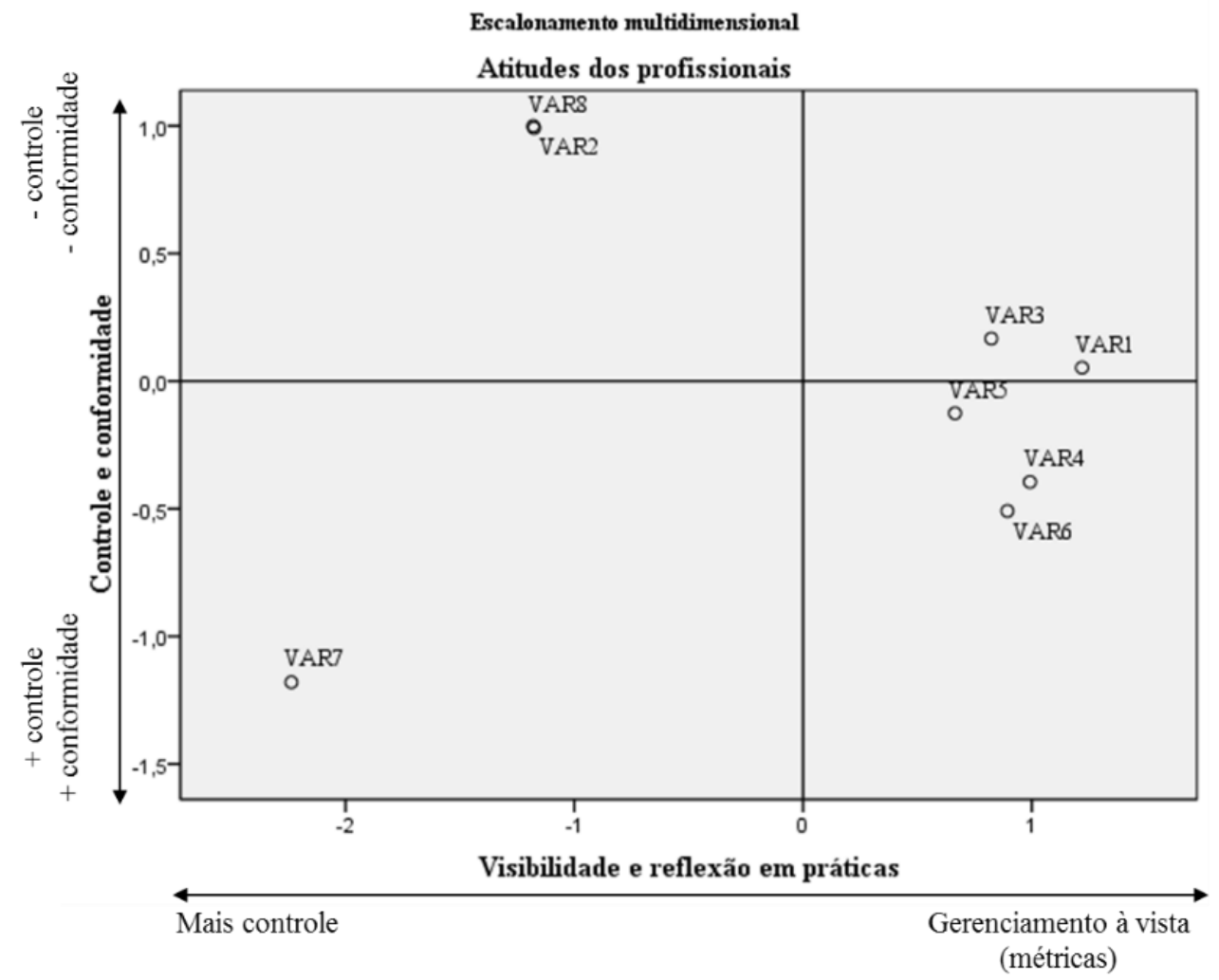

Figura 45 - Classificação das organizações de acordo com as atitudes dos profissionais coletadas na fase 1. 
Em oposição se notam os casos 1 e 7, sendo que o primeiro coloca menos controles coercitivos sobre as atividades para valorizar o gerenciamento por métricas, sendo que o segundo aplica mais controles formais para manter seus processos padronizados de prestação de serviços de TI.

Para chegar a conclusões sobre a totalidade dos dados, além das técnicas para dados qualitativos apresentados na seção 4.2.3, aplicou-se a análise de escalonamento multidimensional (HAIR JR. et al., 2009) através da ferramenta IBM-SPSS v22, ao tratar as variáveis com valores padronizados. As respostas do questionário da fase 1 foram propostas inicialmente desta maneira. As variáveis das entrevistas da fase 2 foram adaptadas de acordo com as possíveis respostas determinadas quando do desenvolvimento de seu roteiro semiestruturado.

A análise foi feita sobre a combinação de 23 variáveis:

- $\quad$ Tamanho da organização (Q4);

- $\quad$ Processo da tomada de decisões (Q5, R1, R9, R11);

- $\quad$ Estratégia e benefícios da adoção da norma (Q8, D4);

- $\quad$ Atitude perante ao risco (Q17, Q18);

- $\quad$ Atitude dos profissionais (D8, Q21 a Q31);

- $\quad$ Processos (R10, D12).

O resultado obtido, cujo stress de 5,6\% e RSQ=0,98 são considerados bons para sua relevância (HAIR JR. et al., 2009), foi representado na Figura 46. "VAR" representa os casos estudados, de acordo com seu número. As dimensões dos eixos foram determinadas com base nos resultados da pesquisa, sendo que seu significado é atribuído pelo pesquisador.

Nota-se em oposição os casos:

- $\quad 2$ e 6: a primeira busca o atendimento dos requisitos de seus clientes mesmo que sejam diferentes de seus padrões para possibilitar seu crescimento, enquanto a segunda buscou no modelo canônico a definição de seus processos de governança de TI;

- $\quad 4$ e 7: o primeiro está mais disposto a customizar soluções para atender a requisitos específicos de seus clientes. 


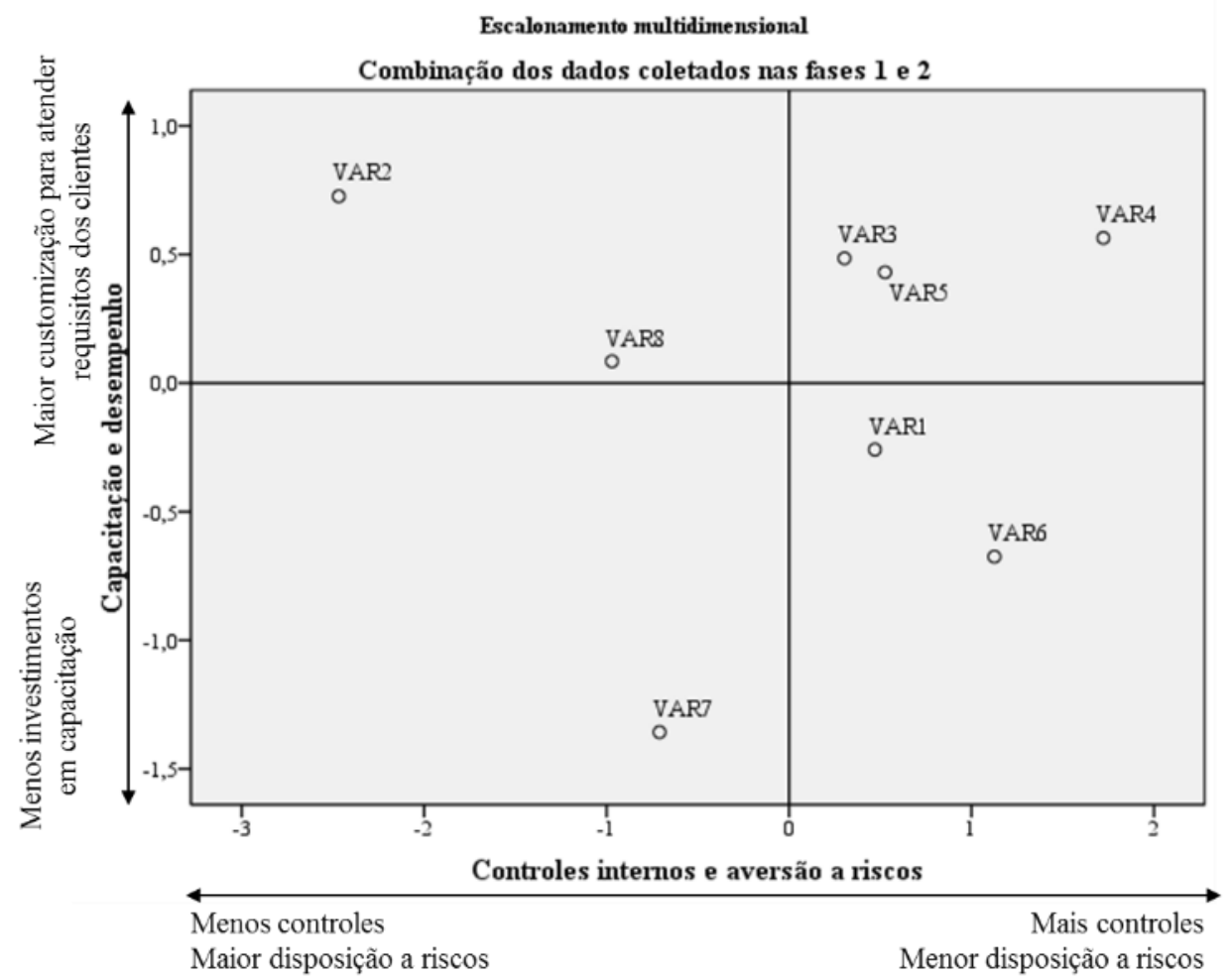

Figura 46 - Análise quantitativa do conjunto de dados obtidos nas fases 1 e 2. 


\section{APÊNDICE 4 - MODELO CANÔNICO: REQUISITOS DA NORMA ISO 20.000}

Os requisitos obrigatórios para as auditorias de certificação para os processos de gerenciamento de serviços de TI do modelo canônico de governança de TI usado nesta pesquisa: a norma ISO 20.000 (ABNT, 2011).

\section{Cláusula 5.2: planejar serviços novos ou modificados}

- Planejamento.

- Acordo com o cliente.

- Considerar impactos financeiros, organizacionais e técnicos.

- Considerar impactos sobre o sistema de gestão de serviços.

- Incluir referências a:

- Autoridades e responsabilidades para atividades de transição.

- Atividades a serem executadas.

- Comunicação.

- Recursos humanos, técnicos e financeiros.

- Escala de tempo para atividades.

- Identificação, avaliação e gerenciamento de riscos.

- Dependências de outros serviços.

- Testes.

- Critérios de aceite.

- Resultados esperados.

- Planejar a remoção, incluindo:

- Data, arquivamento, descarte ou transferência de dados, documentação e componentes (infraestrutura e aplicações).

- Identificar outras partes que contribuem com o provisionamento dos componentes de serviços.

- Avaliar suas habilidades para entregar o serviço.

- Registrar os resultados da avaliação e ações necessárias.

\section{Cláusula 5.3: desenho e desenvolvimento de serviços novos ou modificados}

- Documentar:

- Autoridades e responsabilidades para entrega de serviços novos ou modificados.

- Atividades que devem ser executadas. 
- Requisitos de recursos humanos novos ou modificados, incluindo treinamentos.

○ Recursos financeiros necessários.

○ Tecnologia nova ou modificada.

- Planos e políticas novos ou modificados.

○ Contratos novos ou modificados.

○ Mudanças no sistema de gestão de serviços.

- Acordos de níveis de serviço novos ou modificados.

○ Atualização do catálogo de serviços

- Procedimentos, medidas e informação para a entrega dos serviços.

- Garantir que o desenho habilite o serviço novo ou modificado a cumprir seus requisitos.

- Serviços devem ser desenvolvidos de acordo com a documentação.

\section{Cláusula 5.4: transição de serviços novos ou modificados}

- Testar para verificar se cumprem com os requisitos.

- Verificar com base nos critérios de aceite das partes interessadas.

- Se os critérios não forem alcançados, tomar decisão sobre ações necessárias e entrega.

- Utilizar para processos aprovados para inserção no ambiente produtivo.

- Após o término, relatar os resultados alcançados em relação aos esperados para as partes interessadas.

\section{Cláusula 6.1: Gerenciamento de nível de serviço}

- A grande escala de serviços a serem providos junto aos níveis de serviço correspondentes, devem ser acordados por ambas as partes e registrados.

- Cada serviço prestado deve ser definido, acordado e documentado em um ou mais acordos de nível de serviço.

- Acordos de nível de serviço, juntamente aos acordos de suporte a serviços, contratos de fornecedores e procedimentos correspondentes, devem ser acordados por todas as partes relevantes e registrados.

- Os acordos de nível de serviços devem estar sob controle do processo de gerenciamento de mudanças.

- Os acordos de nível de serviços devem ser mantidos por revisões regulares pelas partes para ter certeza de que eles estão atualizados e continuam efetivos ao tempo excedente.

- Os níveis de serviço devem ser monitorados de acordo com as metas, mostrando ambas as informações correntes e as informações de tendências. 
- $\quad$ As razões de não conformidades devem ser reportadas e revisadas.

- Ações de melhoria identificadas durante esse processo devem prover entrada a uma planta para melhoria do serviço e registradas.

\section{Cláusula 6.2: Relatos de serviço}

- Deve haver uma descrição clara de cada relato de serviço, incluindo sua identidade, propósito, audiência e detalhes da fonte de dados.

- Os relatos de serviço devem ser produzidos para atender necessidades identificadas e requerimentos do cliente.

- Os relatos de serviços devem incluir:

- Desempenho de encontro aos alvos de nível de serviços.

- Não-conformidades e pendências, por exemplo, nos acordos de nível de serviço, culatra de segurança.

- Características de trabalho previstas, por exemplo, volume, utilização de recursos.

- Desempenho, relatando os maiores eventos.

- Informações de tendências.

- Análise de satisfação.

- Decisões de gerenciamento e ações corretivas devem tomar em consideração os resultados nos relatos de serviço e as partes relevantes devem ser comunicadas.

\section{Cláusula 6.3: Gerenciamento de continuidade e disponibilidade de serviço}

- Os requerimentos de disponibilidade e continuidade do serviço devem ser identificados no começo do plano de negócio.

- Nos requerimentos devem incluir direitos de acesso e tempo de resposta como na disponibilidade fim a fim dos componentes do sistema.

- Os planos de disponibilidade e continuidade do serviço devem ser desenvolvidos e revisados no mínimo anualmente para ter certeza de que os requerimentos estão de acordo em todas as circunstâncias normais para que haja menor perda de serviço.

- Estes planos devem ser mantidos para ter certeza de que eles irão refletir em mudanças acordadas requeridas pelo negócio.

- A disponibilidade e continuidade do serviço devem ser testadas novamente para quaisquer maiores mudanças nos planos de disponibilidade e continuidade do serviço.

- O processo de gerenciamento de mudança deve avaliar o impacto de qualquer mudança no plano de disponibilidade e continuidade de serviço. 
- A disponibilidade deve ser medida e registrada.

- Indisponibilidades não programadas devem ser investigadas e ações apropriadas serem tomadas.

- Os planos de continuidade do serviço, listas de contato e a base de dados de gerenciamento de configuração, devem estar disponíveis quando avaliações usuais no escritório são impedidas.

- O plano de continuidade do serviço deve incluir o trabalho de retorno à normalidade.

- O plano de continuidade do serviço deve ser testado de acordo com as necessidades do negócio.

- Todos os testes de continuidade devem ser registrados.

- Falhas nos testes devem ser formuladas em planos de ação.

\section{Cláusula 6.4: Orçamento e contabilização para serviços}

- Devem haver políticas e processos bem claros para:

- Orçamento e planejamento para todos os componentes incluindo equipamentos de TI, recursos compartilhados, overheads, serviço de fornecedores externos, pessoas, seguros e licenças.

- Alocar custos indiretos e alocação de custos diretos a serviços.

- Controle e autorizações financeiras efetivas.

- O orçamento de custos deve ser suficientemente detalhado para ter em mãos o controle financeiro e as tomadas de decisões.

- O provedor de serviços deve monitorar e reportar os custos de encontro ao orçamento, rever as projeções financeiras e gerenciar os custos.

- Mudanças de serviços devem ter os custos definidos e aprovados através do processo de gerenciamento de mudanças.

\section{Cláusula 6.5: Gerenciamento da capacidade}

- Produzir e manter um plano de capacidade.

- Endereçar as necessidades de negócio e incluir:

- Requerimentos de capacidade e desempenho atuais e projetadas.

- Identificar escalas de tempo, gastos e custos para atualizações do serviço.

- Avaliações de efeito de atualizações antecipadas, requerimentos de mudanças, novas tecnologias e tecnologias de capacidade.

- Impacto projetado de mudanças externas, por exemplo, legislativas.

- Dados e processos para ter análises projetadas. 
- Métodos, procedimentos e técnicas devem ser identificadas para monitorar a capacidade do serviço, sintonizar o desempenho do serviço e prover a capacidade adequada.

\section{Cláusula 6.6: Gestão da segurança da informação}

- Gerenciamento com autoridade apropriada deve aprovar uma política de segurança de informações.

- A política de segurança de informações deve ser comunicada a todos os grupos de funcionários relevantes e clientes apropriados.

- Controles de segurança apropriados devem operar como:

- Implantar os requerimentos da política de segurança de informações.

- Gerenciar os riscos associados com avaliações ao sistema ou ao serviço.

- Controles de segurança devem ser documentados.

- A documentação deve descrever os riscos dos controles relatados e a maneira de operar e manter os controles.

- O impacto de mudanças nos controles deve ser avaliado antes das mudanças serem implantadas.

- Combinações que envolvam organizações externas tendo avaliações de sistemas e serviços de informação devem ser baseados em um acordo formal que defina todos os requerimentos de segurança.

- Incidentes de segurança devem ser reportados e registrados em linha com os procedimentos de gerenciamento de incidentes como possível.

- Procedimentos devem estar no lugar para certificar que todos os incidentes de segurança são investigados e ações de gerenciamento serem tomadas.

- Mecanismos devem estar no lugar para ter certeza de que tenham tipos, volumes e impactos de incidentes de segurança e mal funcionamentos sejam quantificados e monitorados.

- Ações de melhoria identificadas durante este processo devem ser registradas e prover entradas a um plano de melhorias do serviço.

\section{Cláusula 7.1: Gerenciamento de relações de negócio}

- O provedor de serviços deve identificar e documentar os stakeholders e os clientes dos serviços 
- O provedor de serviços junto ao cliente deve atender a uma revisão do serviço para discutir qualquer mudança no escopo do serviço, Nível de disponibilidade acordado, contrato (se apresentado), ou necessidades do negócio no mínimo anualmente.

- O provedor de serviços junto ao cliente devem assegurar reuniões com intervalos acordados para discutir, desempenho, objetivos, pendências e planos de ação.

- As reuniões devem ser documentadas.

- Mudanças de contratados, se realizadas, e níveis de disponibilidade do serviço acordados devem seguir nessas reuniões apropriadamente.

- Essas mudanças devem ser subjetivas ao processo de gerenciamento de mudanças.

- O provedor de serviços deve permanecer atento às necessidades do negócio e maiores mudanças estando preparado para responder a estas necessidades.

- Devem haver processos de queixa.

- A definição de um serviço formal de queixa deve ser acordada com o cliente.

- Todos os serviços formais de queixa devem ser registrados pelo provedor do serviço, investigados, sofrer ações, reportados e formalmente fechados.

- Quando uma queixa não é resolvida através de meios normais, o escalonamento deve estar disponível ao cliente.

- O provedor do serviço deve ter uma pessoa ou mais nomeadas para gerenciar a satisfação do cliente e todo o processo de relacionamento de negócio.

- Deve haver um processo para obtenção e atuação sobre o retorno das medidas de satisfação do cliente.

- Ações de melhoria identificadas ao longo deste processo devem ser registradas e servir de entrada para um plano de melhoria do serviço.

\section{Cláusula 7.2: Gerenciamento de fornecedores}

- O provedor do serviço deve ter documentado o processo de gerenciamento de fornecedores.

- O provedor de serviço deve nomear um gerente contratado responsável para cada fornecedor.

- Os requerimentos, escopo, nível de serviços e processos de comunicação para serem providos pelos fornecedores devem ser documentados em acordos de nível de serviço ou em outros documentos e serem acordados por todas as partes.

- Acordos de nível de serviço, com fornecedores devem ser alinhados com acordos de nível de serviço do negócio. 
- As interfaces entre processos utilizados por cada parte devem ser documentadas e acordadas.

- Todos os papéis e relacionamentos entre líder e fornecedores subcontratados devem ser claramente documentados.

- Líderes fornecedores devem demonstrar os processos para ter certeza de que os fornecedores subcontratados vão de encontro aos requerimentos contratuais.

- Um processo deve estar implantado para maior revisão do contrato ou acordos formais no mínimo anualmente para ter certeza de que as necessidades do negócio e obrigações contratuais continuam sendo atendidas.

- Mudanças de contratos, se realizadas, e acordos de nível de serviço devem seguir revisões apropriadamente ou em outros momentos se requeridos.

- Quaisquer mudanças devem ser subjetivas ao processo de gerenciamento de mudanças.

- Um processo deve existir para acordar com disputas contratuais.

- Um processo deve estar no lugar para acordar com o fim do serviço esperado, fím do serviço recente ou transferência do serviço para outra parte.

- Desempenho de encontro aos alvos de nível de serviços devem ser monitorados e revisados.

- Ações de melhoria identificadas ao longo deste processo devem ser registradas e servir de entrada para um plano de melhoria do serviço.

\section{Cláusula 8.1: Gerenciamento de incidentes e requisições de serviço}

- Todos os incidentes devem ser registrados.

- Procedimentos devem ser adotados para gerenciar o impacto dos incidentes.

- Procedimentos devem definir o registro, priorização, impacto ao negócio, classificação, atualização, escala, resolução e fechamento formal de todos os incidentes.

- O cliente deve ser mantido informado do progresso ou dos incidentes reportados, ou requerimento de serviços e alertas avançados se o nível de serviço dele não pode ser alcançado, e ações acordadas.

- Toda equipe envolvida no gerenciamento de incidentes deve ter acesso a informações relevantes como erros conhecidos, soluções de problemas e ao banco de dados do gerenciamento de configuração (CMDB).

- Maiores incidentes devem ser classificados e gerenciados de acordo com um processo.

\section{Cláusula 8.2: Gerenciamento de problemas}


- Todos os problemas identificados devem ser registrados.

- Procedimentos devem ser adotados para identificar, minimizar ou evitar impacto de incidentes e problemas.

- Esses procedimentos devem definir o registro, classificação, atualização, escala, resolução e fechamento de todos os problemas.

- Ações preventivas devem ser tomadas para reduzir problemas potenciais, por exemplo, seguimento de direção de análise de tipos e volumes de incidentes.

- Mudanças solicitadas para corrigir causas subjacentes de problemas devem ser passadas ao processo de gerenciamento de mudanças.

- Resolução de problemas devem ser monitoradas, revisadas e reportadas por efetividade.

- Gerenciamento de problemas deve ser responsável por ter certeza de que informações de erros conhecidos e problemas corrigidos estar disponível para o gerenciamento de incidentes.

- Ações de melhoria identificadas ao longo deste processo devem ser registradas e servir de entrada para um plano de melhoria do serviço.

\section{Cláusula 9.1: Gerenciamento da configuração}

- Deve haver um plano integrado e aproximado ao gerenciamento de mudança e configuração.

- O provedor de serviço deve definir a interface entre os recursos financeiros de processos de contabilidade.

- Deve haver uma política de como é definido um item de configuração e seus componentes constitucionais.

- As informações a serem registradas para cada item devem ser definidas.

- As informações registradas devem incluir as relações e documentações necessárias para o efetivo gerenciamento de serviços.

- O gerenciamento de configuração deve prover os mecanismos para identificação, controle e seguimento de versões de componentes identificáveis de serviço e infraestrutura.

- Os mecanismos devem dar certeza de que o grau de controle é suficiente para atender as necessidades do negócio, riscos de falha e criticidade do serviço.

- O gerenciamento de configuração deve prover informações para o processo de gerenciamento de mudanças no impacto de uma ação requerida nas configurações do serviço ou da infraestrutura. 
- Mudanças em itens de configuração devem ser traçadas e auditadas apropriadamente, por exemplo, mudanças e movimentos de software e hardware.

- Procedimentos de controle de configurações devem dar certeza de que a integridade de sistemas, serviços e componentes de serviços será mantida.

- Um baseline da configuração de itens apropriada deve ser pego antes da atualização do ambiente atual.

- Cópias mestres dos itens de configuração digital devem ser controladas em bibliotecas seguras físicas, ou eletrônicas e referenciadas aos registros de configuração, por exemplo, softwares, produtos de teste, documentos suportados.

- Todos os itens de configuração devem ser unicamente identificados e registrados no Banco de dados do gerenciamento de configuração.

- Os acessos de atualização do banco de dados de gerenciamento de configuração devem ser estritamente controlados.

- O banco de dados de gerenciamento de configuração deve ser gerenciado e verificado ativamente para dar certeza de confiabilidade e exatidão.

- Os estados de itens de configuração, suas versões, localização, problemas e mudanças relacionadas e documentação associada devem ser visíveis àqueles que solicitarem.

- Procedimentos de auditoria de configuração devem incluir deficiências registradas, inicio de ações corretivas e relato nos resultados.

\section{Cláusula 9.2: Gerenciamento de mudanças}

- Mudanças de serviço e infraestrutura devem ter um claro e documentado escopo.

- Todos os requerimentos de mudança devem ser registrados e classificados, por exemplo, urgência, emergência, principal, menor.

- Requerimentos de mudanças devem ser avaliados pelo seu risco, impacto e benefícios ao negócio.

- O processo de gerenciamento de mudanças deve incluir a maneira pela qual a mudança será revertida ou remediada se não obtiver sucesso.

- Mudanças devem ser aprovadas e depois checadas.

- Mudanças devem ser implantadas de uma maneira controlada.

- Todas as mudanças devem ser revisadas para o sucesso e qualquer ação tomada após a implantação.

- Deve haver políticas e procedimentos para controlar a autorização e implementação de mudanças emergenciais. 
- As datas programadas de implantação de mudanças devem ser usadas como base para mudanças e atualizações programadas.

- Uma programação que contém detalhes de todas as mudanças aprovadas para implantação e as datas de implantação propostas devem ser mantidas e todas as partes relevantes comunicadas.

- Registros de mudanças devem ser analisados para detectar acréscimo de níveis de mudança, frequentes tipos de mudanças recorrentes, tendências emergentes e outras informações relevantes.

- Os resultados e conclusões desenhados de uma análise de mudança devem ser registrados.

- Ações de melhoria identificadas no gerenciamento de mudança devem ser registradas e servir de entrada para o plano de melhoria do serviço.

\section{Cláusula 9.3: Gerenciamento de liberação e implantação}

- O policiamento de atualizações indicando a frequência e o tipo de atualizações deve ser documentado e acordado.

- O provedor de serviços deve planejar com os negócios as atualizações dos serviços, sistemas, software e hardware.

- Os planos para dar continuidade às atualizações devem ser acordados e autorizados pelas partes relevantes, por exemplo, clientes, usuários, operadores e o grupo de suporte.

- O processo deve incluir a maneira em que as atualizações devem ser revertidas ou remediadas se não tiver sucesso.

- Os planos devem registrar as datas de entrega e referi-las aos relatos de mudanças requeridas, erros e problemas conhecidos.

- O processo de gerenciamento de atualizações deve passar informações apropriadas para o processo de gerenciamento de incidentes.

- Requerimentos de mudanças devem ser avaliados pelo seu impacto nos planos de atualização.

- Os procedimentos de gerenciamento de atualizações devem incluir as atualizações e mudanças de informações de configuração e registros de mudança.

- Atualizações emergenciais devem ser gerenciadas de acordo com o processo definido que tenha interface com o processo de gerenciamento de mudanças emergenciais.

- Um teste do ambiente controlado de aceitação deve ser estabelecido para construir e testar todas as atualizações previamente para distribuição. 
- Atualização e distribuição devem ser desenhadas e implantadas mantendo a integridade do hardware e software durante a instalação, manipulação, empacotamento e entrega.

- Sucesso e falha das atualizações devem ser medidos.

- As medições devem incluir os incidentes relacionados a uma atualização no período seguido da mesma.

- As análises devem conter avaliações de impacto no negócio, operações de TI e grupos de recursos de suporte.

- As análises devem prover entrada para um plano de melhoria de serviço. 